Isabela de Paula Salgado

Avaliação do Comportamento Mecânico de Painéis Sanduíche com Compósitos Laminados Reforçados com Fibra de Curauá e Núcleo de Concreto Celular Autoclavado

Dissertação de Mestrado

Dissertação apresentada como requisito parcial para obtenção do grau de Mestre pelo Programa de PósGraduação em Engenharia Civil do Departamento de Engenharia Civil e Ambiental da PUC-Rio.

Orientador: Prof. Flávio de Andrade Silva 


\section{Avaliação do Comportamento Mecânico de Painéis Sanduíche com Compósitos Laminados Reforçados com Fibra de Curauá e Núcleo de Concreto Celular Autoclavado}

Dissertação apresentada como requisito parcial para obtenção do grau de Mestre pelo Programa de PósGraduação em Engenharia Civil do Departamento de Engenharia Civil e Ambiental do Centro Técnico Científico da PUC-Rio. Aprovada pela Comissão Examinadora abaixo.

Prof. Flávio de Andrade Silva

Orientador

Departamento de Engenharia Civil e Ambiental - PUC-Rio

Dra. Lourdes Maria Silva de Souza

Instituto Tecgraf - PUC-Rio

Prof. Daniel Carlos Taissum Cardoso

Departamento de Engenharia Civil e Ambiental - PUC-Rio 
Todos os direitos reservados. É proibida a reprodução total ou parcial do trabalho sem a autorização da universidade, do autor e do orientador.

\section{Isabela de Paula Salgado}

Graduada em Engenharia Civil pela Pontifícia Universidade Católica do Rio de Janeiro em 2016. Áreas de interesse: Fibras naturais, materiais compósitos, sustentabilidade.

Ficha Catalográfica

Salgado, Isabela de Paula

Avaliação do Comportamento Mecânico de Painéis Sanduíche com Compósitos Laminados Reforçados com Fibra de Curauá e Núcleo de Concreto Celular Autoclavado / Isabela de Paula Salgado; Orientador: Flávio de Andrade Silva -2019

$171 f$.il. color $; 30 \mathrm{~cm}$

Dissertação (Mestrado) - Pontifícia Universidade Católica do Rio de Janeiro, Departamento de Engenharia Civil e Ambiental, 2019.

Inclui referências bibliográficas.

1. Engenharia Civil e Ambiental - Teses. 2. Painéis sanduíche. 3. Concreto celular autoclavado. 4. Compósitos cimentícios. 5. Fibras naturais. 6. Desempenho mecânico. I. Silva, Flávio de Andrade II. Pontifícia Universidade Católica do Rio de Janeiro. Departamento de Engenharia Civil e Ambiental. III. Título. 


\section{Agradecimentos}

Agradeço primeiramente ao meu orientador, Flávio de Andrade Silva, o qual admiro profundamente e sou particularmente grata por ter me acompanhado nas pesquisas desde a graduação. Cada momento de incentivo, paciência e conhecimento partilhado foram determinantes para o meu crescimento no meio científico, e me sinto feliz e honrada pela oportunidade.

A todos do Laboratório de Materiais e Estruturas da PUC-Rio, que me auxiliaram e acompanharam na realização desse trabalho, agradeço o companheirismo e a amizade: Euclides, Rogério, Bruno, Carlos, Marques e José. Sem a experiência de vocês, o meu projeto não seria o mesmo. Aos estagiários do laboratório, em especial Igor e Lucas, pela dedicação e disponibilidade. Agradeço à universidade PUC-Rio, pela infraestrutura, recursos e oportunidades; a todos os professores que estimularam minha superação e aprimoramento, assim como a busca de todo o conhecimento que me fosse possível. Ao Prof. Conrado Rodrigues (CEFET-MG), pela disponibilização de materiais de suma-importância ao trabalho. Ao Yuri Nascimento e ao Prof. Otávio Gomes (CETEM) pela atenção e boa vontade em me auxiliar com as micrografias do MEV. Agradeço igualmente ao Prof. Folker Wittmann, o qual foi incrivelmente gentil ao me enviar a única cópia de um de seus livros.

Agradeço a todos que, de uma forma ou outra, estiveram ao meu lado durante esse trajeto, me proporcionando todo o amor que eu poderia desejar. Às amizades que tornaram essa conquista possível: Wena, Letícia, Felipe, Victor, Tathiana, Fernando, Filipe, Kíssila, Vítor, Gisele e Priscila, os quais admiro fortemente e que me ajudaram de forma indescritível. Um agradecimento especial à minha família, pelo cuidado, suporte e confiança em mim. À minha mãe, Rachel, a quem eu amo muito e sem a qual eu nada seria. À minha irmã, Isadora, por todo o carinho e amizade ao longo de tantos anos. Ao meu pai, Humberto, pelo grande incentivo e respeito às minhas conquistas. Às minhas tias Norma e Bia, que amo tanto, e à tia 
Márcia, a quem eu desejaria tanto que pudesse estar conosco. Ao meu avô Luíz Fernando, por ser tão especial e carinhoso. Agradeço também à Marina, pelo apoio incondicional, afeto único e infinidade do que representa. À Giulia, por ser essencial para mim e estar sempre presente, não importa aonde esteja. Ao Lucas, Raphael e Cabral pela compreensão e importância na minha vida. Aos meus amigos Eduardo, Luma, Luana, Ana, Barrozo, Priscilla, Miguel, Luíza, Nathália, Bia e Pedro Guilherme um agradecimento especial pela amizade sincera.

O presente trabalho foi realizado com apoio da Coordenação de Aperfeiçoamento de Pessoal de Nível Superior - Brasil (CAPES) - Código de Financiamento 001. Agradeço igualmente às outras agências de fomento sem as quais o presente trabalho não teria sido possível: o Conselho Nacional de Desenvolvimento Científico e Tecnológico (CNPq) e a Fundação de Amparo à Pesquisa do Estado do Rio de Janeiro (FAPERJ). Às empresas Lafarge, Holcim e Viapol pelo material utilizado no projeto. 


\section{Resumo}

Salgado, Isabela de Paula; Silva, Flávio de Andrade (Orientador). Avaliação do Comportamento Mecânico de Painéis Sanduíche com Compósitos Laminados Reforçados com Fibra de Curauá e Núcleo de Concreto Celular Autoclavado. Rio de Janeiro, 2019. 171p. Dissertação de Mestrado - Departamento de Engenharia Civil e Ambiental. Pontifícia Universidade Católica do Rio de Janeiro.

O presente trabalho propõe-se a analisar o comportamento mecânico de painéis sanduíche constituídos por duas camadas externas de compósitos cimentícios reforçados com fibras naturais, separadas por um núcleo de concreto celular autoclavado (CCA). Cada placa de material compósito foi moldada diretamente sobre a superfície de um bloco de CCA, por meio da disposição manual de três camadas unidirecionais de fibras longas de curauá. Visando prover maior durabilidade ao compósito, desenvolveu-se uma matriz com baixo teor de hidróxido de cálcio, substituindo uma parcela do cimento por materiais pozolânicos. Ensaios de caracterização da matriz, dos filamentos de curauá e dos blocos de CCA foram realizados para a obtenção de suas propriedades independentes. Os compósitos foram submetidos a ensaios de arrancamento do tecido, tração direta e flexão a quatro pontos para a avaliação de diferentes aspectos de seus mecanismos de fissuração, resistência e capacidade de deformação. Zonas de carregamento foram indicadas em cada caso para demonstrar o comportamento padrão dos compósitos. Os painéis sanduíche, por sua vez, foram analisados em termos de interface, por meio de ensaios de aderência e micrografias da superfície de transição dos materiais, e de desempenho mecânico, por ensaios de flexão a quatro pontos cíclicos e monotônicos. Esses últimos forneceram a rigidez, capacidade de carga e deflexão dos painéis sanduíche, tal como as principais propriedades de seus elementos: para o núcleo, a resistência ao cisalhamento e o módulo de cisalhamento, e para as lâminas, a resistência à compressão e à tração. Os ensaios cíclicos testaram a resistência do material a séries de carregamentodescarregamento, enquanto ensaios de aderência foram utilizados para verificar a 
interface entre os compósitos laminados e o núcleo de CCA. Os resultados indicaram um desempenho satisfatório dos painéis sanduíche, uma vez que os compósitos foram capazes de lhes fornecer um comportamento de strain/deflection hardening, aumentando sua resistência e tenacidade. A adesão entre lâminas-núcleo mostrou-se eficaz, de maneira que os diferentes materiais compreendidos demonstraram interação adequada entre si, bem como propriedades complementares. Dentre os objetivos desse trabalho, encontra-se o desenvolvimento de um material sustentável, leve, resistente e tenaz, de modo que constitua uma alternativa promissora e de baixo custo a aplicações de Engenharia.

\section{Palavras-chave}

Painéis sanduíche; Concreto celular autoclavado; Compósitos cimentícios; Fibras naturais; Desempenho mecânico. 


\section{Abstract}

Salgado, Isabela de Paula; Silva, Flávio de Andrade (Advisor). Evaluation of the Mechanical Behavior of Sandwich Panels with Curauá FiberCement Composite Layers and Autoclaved Aerated Concrete Core. Rio de Janeiro, 2019. 171p. Dissertação de Mestrado - Departamento de Engenharia Civil e Ambiental. Pontifícia Universidade Católica do Rio de Janeiro.

This present work aims to analyze the mechanical behavior of sandwich panels consisting of two outer layers of natural fiber-reinforced cementitious composites separated by a core layer of autoclaved aerated concrete (AAC). The molding of each composite layer was made directly on the surface of an AAC block, by manually arranging three layers of long unidirectional aligned curauá fibers in the mortar. In order to increase the composite durability, a matrix with a low content of calcium hydroxide was developed, where the Portland cement was partially replaced by pozzolanic materials. Characterization tests of the matrix, the curauá filaments and the AAC blocks were performed to obtain their independent properties. The composites were submitted to fabric pull-out tests, direct tensile tests and four-point bending to evaluate different aspects of their cracking mechanisms, strength and deformation capacity. Loading zones were indicated in each case to demonstrate the standard composite behavior. The sandwich panels, on the other hand, were analyzed in terms of interface, through pull-off tests and SEM images of the materials transition surface, and mechanical performance, by means of cyclic and monotonic four-point bending tests. The latter registered the rigidity, load capacity and deflection of the sandwich panels, as well as the main properties of their elements: for the core, shear strength and shear modulus, and for the skin layers, compressive strength and tensile strength. Cyclic tests evaluated the resistance of the material to loading-unloading cycles, while pull-off tests were used to verify the interface between the laminated composites and the AAC core. The results indicated a satisfactory performance of the sandwich panels, since the composite layers provided a strain/deflection hardening behavior to the material, 
increasing its flexural strength and toughness. The adhesion between the layers and the core proved to be effective, so that the comprised materials displayed adequate interaction between each other, as well as complementary properties. Among the objectives of this work is the development of a sustainable, lightweight, resistant and tough material, in a way that it represents a promising and low-cost alternative to Engineering applications.

\section{Keywords}

Sandwich panels; Autoclaved aerated concrete; Cementitious composite; Natural fibers; Mechanical performance. 


\section{Sumário}

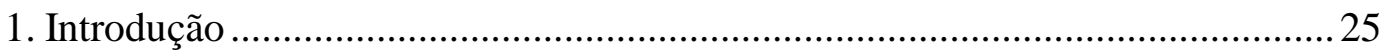

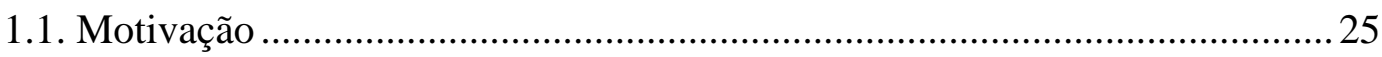

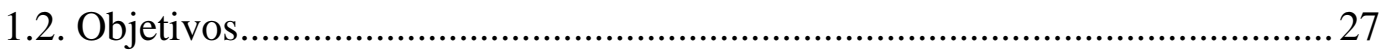

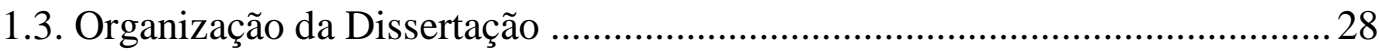

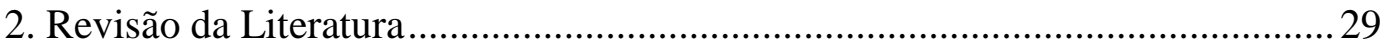

2.1. Fibras Vegetais: Características Físico-químicas e Mecânicas ........................29

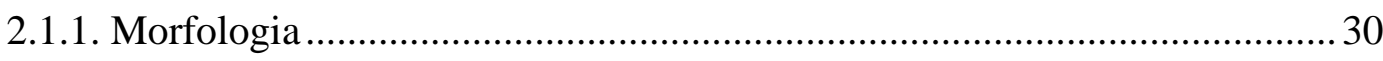

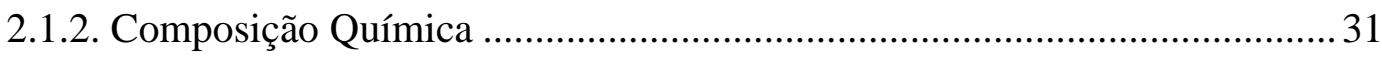

2.1.3. Propriedades Mecânicas ................................................................................ 32

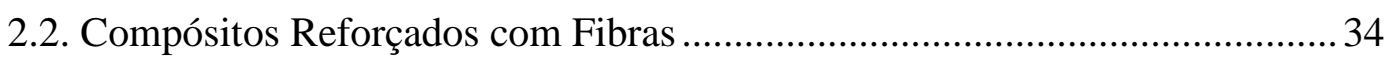

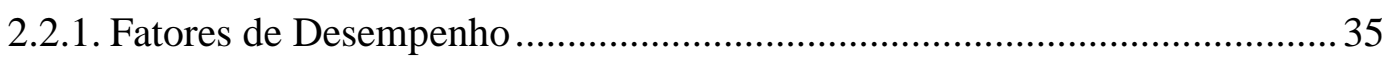

2.2.2. Compósitos Cimentícios Reforçados com Fibras Naturais ............................ 38

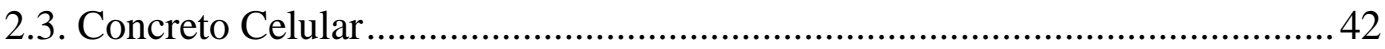

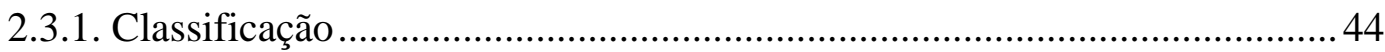

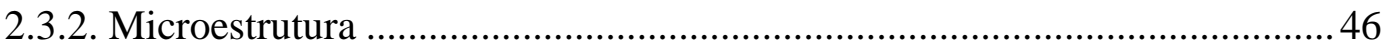

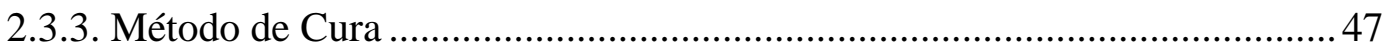

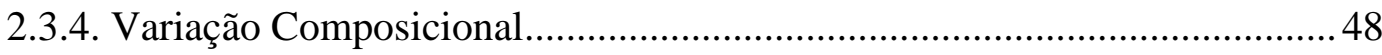

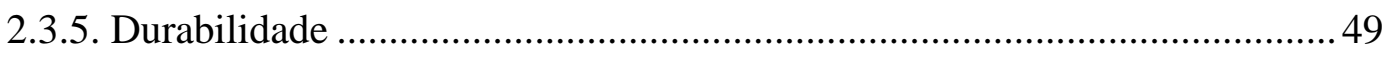

2.3.6. Desempenho Mecânico................................................................................ 51

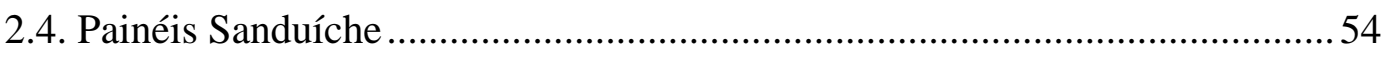

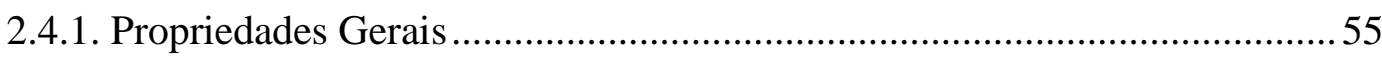

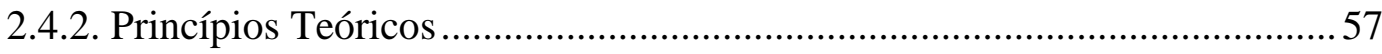




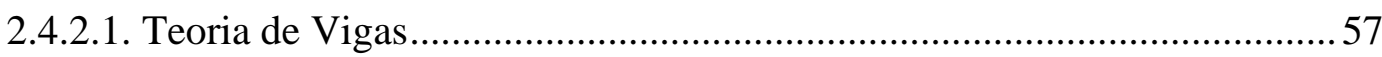

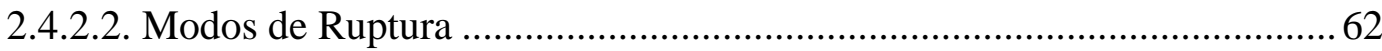

2.4.3. Comportamento Mecânico de Painéis Sanduíche Cimentícios .................... 64

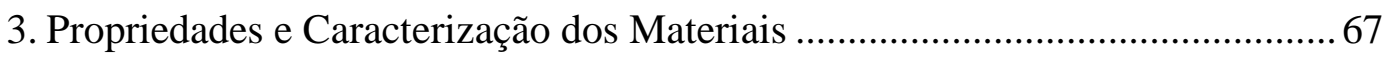

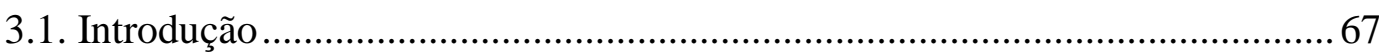

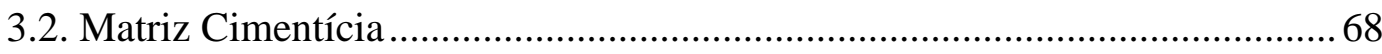

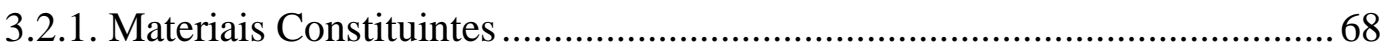

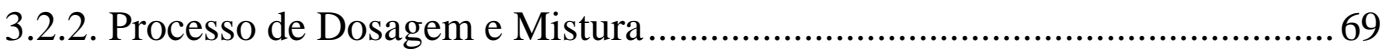

3.2.3. Propriedades da Matriz em Estado Fresco ..................................................... 70

3.2.4. Propriedades da Matriz em Estado Endurecido........................................... 71

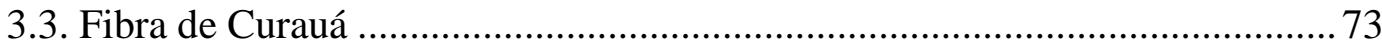

3.3.1. Características Gerais e Beneficiamento …................................................. 73

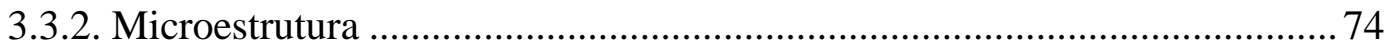

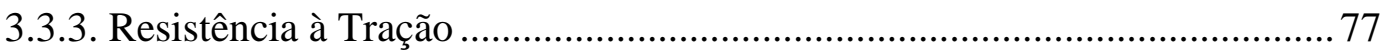

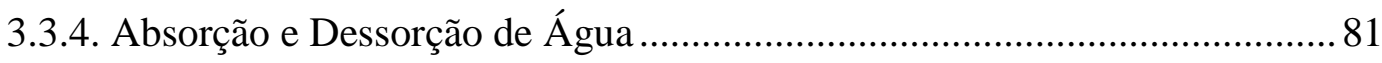

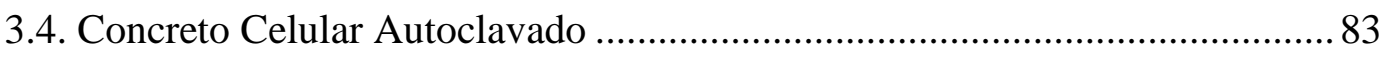

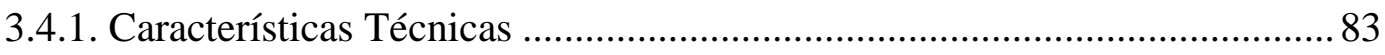

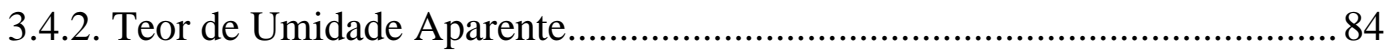

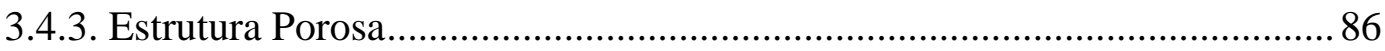

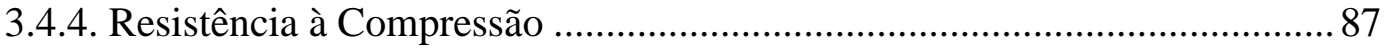

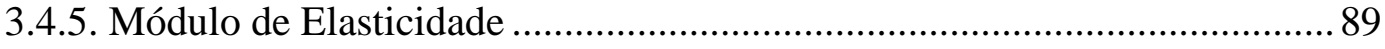

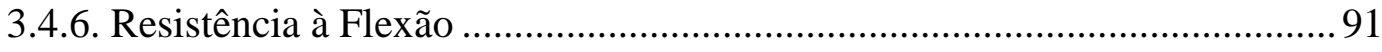

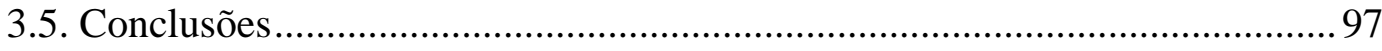

4. Desempenho Mecânico de Compósitos Cimentícios Reforçados com Fibra

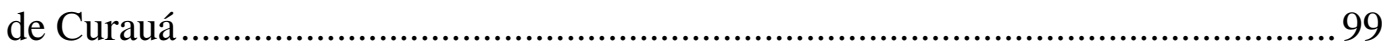




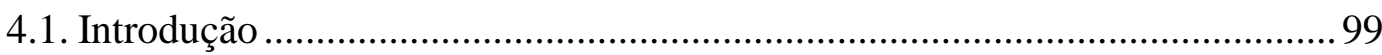

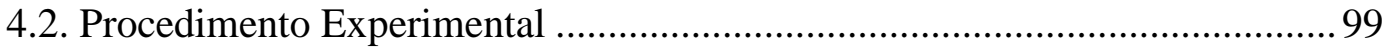

4.2.1. Processo de Fabricação dos Compósitos .......................................................99

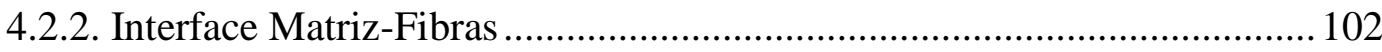

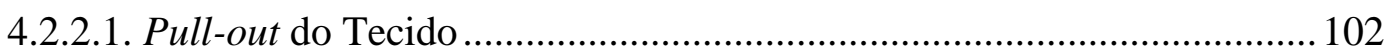

4.2.3. Comportamento Mecânico........................................................................... 104

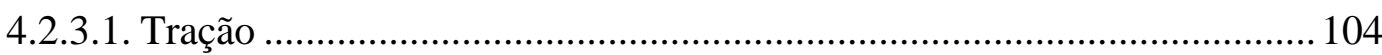

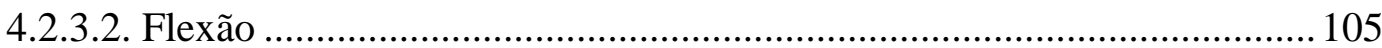

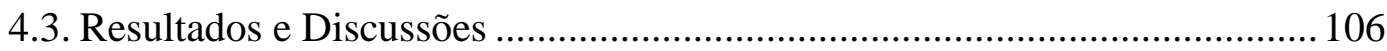

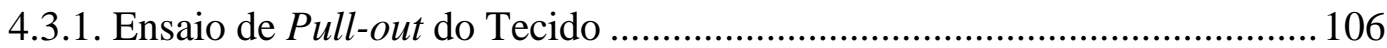

4.3.2. Ensaio de Tração Direta ............................................................................ 108

4.3.3. Ensaio de Flexão a Quatro Pontos .............................................................. 112

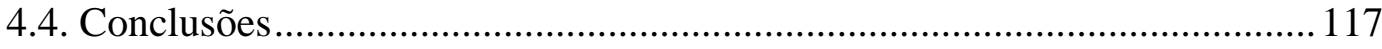

5. Desempenho Mecânico de Painéis Sanduíche Compósitos ............................ 118

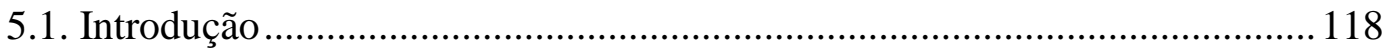

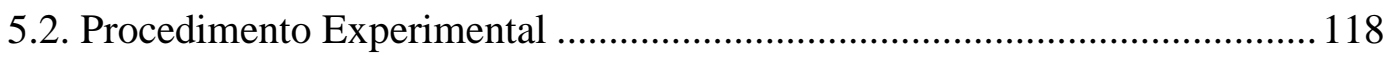

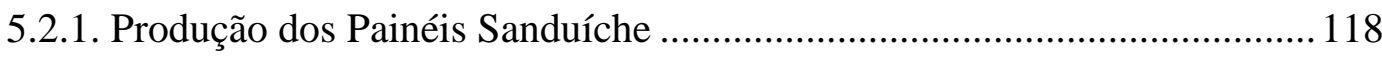

5.2.2. Aderência entre Lâminas e Núcleo............................................................ 120

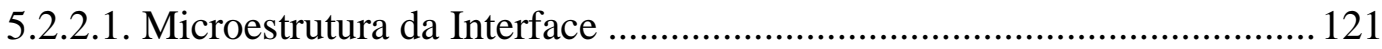

5.2.2.2. Propriedade de Aderência.................................................................... 122

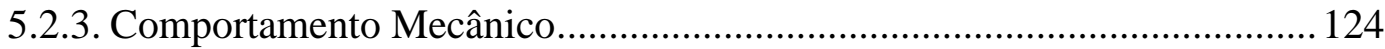

5.2.3.1. Flexão Monotônica ........................................................................... 125

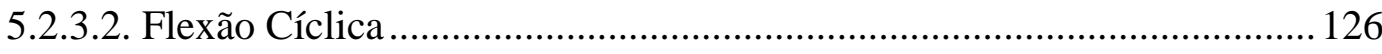

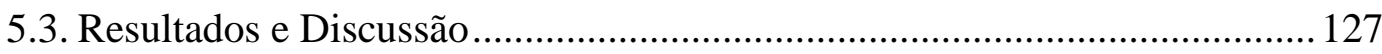

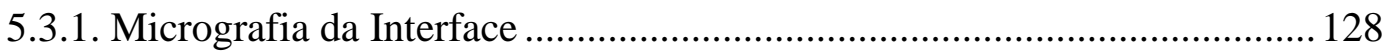

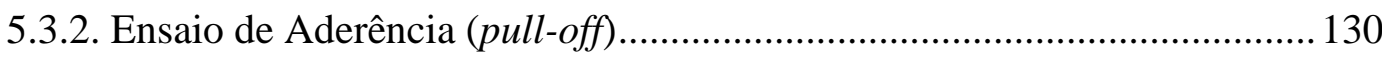


5.3.3. Ensaio Monotônico de Flexão a Quatro Pontos ......................................... 133

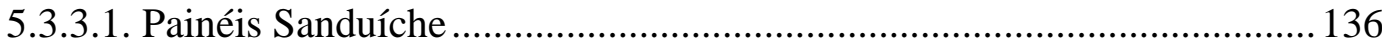

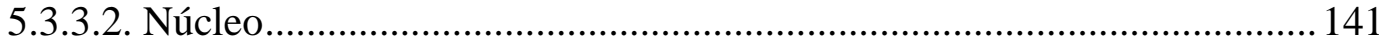

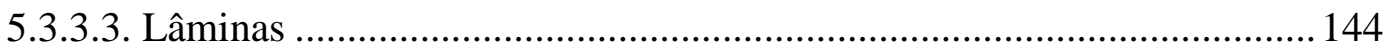

5.3.4. Ensaio Cíclico de Flexão a Quatro Pontos ............................................... 146

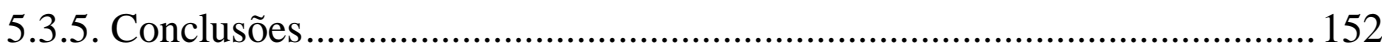

6. Conclusões e Trabalhos Futuros ..................................................................... 154

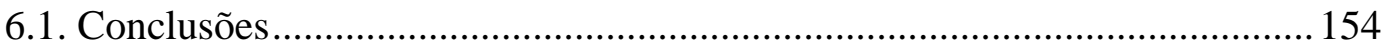

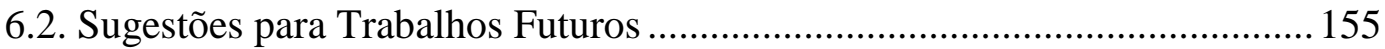

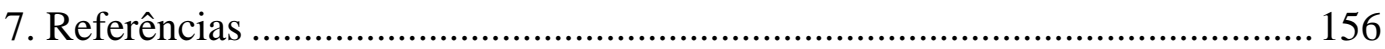

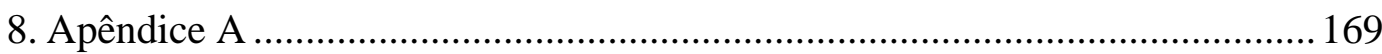

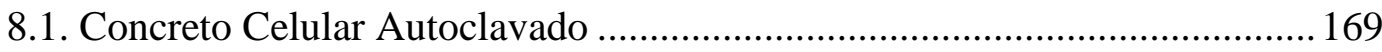

8.2. Fibra de Curauá e Compósito Cimentício ................................................... 170 


\section{Lista de Figuras}

Figura 2-1: Estrutura de uma fibra vegetal, na qual S1, S2 e S3 representam as paredes secundárias externa, intermediária e interna, respectivamente. Adaptado de PEREIRA et al. (2015) 30

Figura 2-2: Arranjo de fibras longas (a,c), dispostas ao longo da matriz de forma contínua, e fibras curtas $(b, d)$, dispersas na matriz.Fonte: BENTUR e MINDESS (1990).

Figura 2-3: Concreto sem finos, concreto celular e concreto de agregado leve, respectivamente. Fonte: NEWMAN e CHOO (2003)

Figura 2-4: Classificação do concreto celular. Adaptado de HAMAD (2014) ..... 45

Figura 2-5: Tipos comuns de núcleo. Adaptado de PFLUG et al. (2002) 55

Figura 2-6: Dimensões de uma viga sanduíche e de sua seção transversal, medidas pelo eixo central da estrutura. Adaptado de ALLEN (1969) .57 Figura 2-7: Benefício mecânico dos painéis sanduíche a partir do aumento da razão entre a espessura do núcleo e a espessura das lâminas,de 0 a 3 vezes maior. Adaptado de VIZZINI (2010)

Figura 2-8: Distribuição de tensões sob flexão: acima, comportamento de uma única lâmina; abaixo, diagrama estimado para painéis sanduíche.

Adaptado de WENNHAGE (2001) 60

Figura 2-9: Distribuição das tensões cisalhantes na viga sanduíche:

a) verdadeira distribuição de tensões, representada pela equação (2-7);

b) para um núcleo pouco resistente (condições 2-3 e 2-8 satisfeitas);

c) para um núcleo pouco resistente e desconsideração da flexão das lâminas em seu próprio eixo centroidal (condições 2-2, 2-3 e 2-8 satisfeitas). Adaptado de ALLEN (1969) 62

Figura 2-10: Representação dos modos de ruptura dos painéis sanduíche e dos esforços atuantes, quando aplicável. O modo i representa a ruptura por tração das lâminas; o modo ii demonstra o enrugamento das lâminas; o modo iii indica a ruptura por fissuras de cisalhamento no núcleo; 
o modo iv representa o descolamento entre lâmina e núcleo.

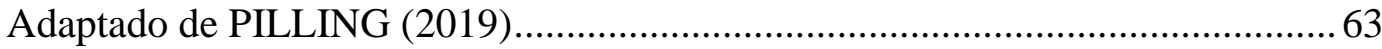

Figura 3-1: Organograma do procedimento experimental geral do trabalho .........68

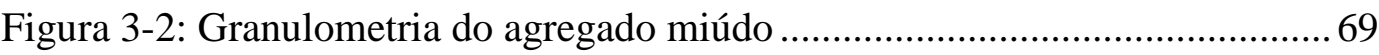

Figura 3-3: Processo de mistura: a) mistura composta por areia e água;

b) adição dos materiais cimentícios e água restante;

c) argamassa após a adição do superplastificante e mistura em alta velocidade ... 70

Figura 3-4: Teste de consistência: a) argamassa inserida no molde;

b) medida de um dos diâmetros;

c) medida do diâmetro consecutivo, em detalhe 71

Figura 3-5: Ensaio de compressão do corpo de prova cilíndrico ........................... 72

Figura 3-6: Resistência à compressão dos corpos de provas ao longo

do tempo, em diferentes idades de cura ............................................................. 72

Figura 3-7: Processo de separação dos filamentos: a) ferramenta utilizada para separar e pentear as fibras;

b) diferença entre as fibras antes e após o processo .74

Figura 3-8: Aparatos de análise: a) detalhe da disposição dos filamentos

de fibras para a análise microscópica;

b) equipamento utilizado para a deposição de camada de ouro na seção transversal das fibras;

c) microscópio eletrônico de varredura (MEV) utilizado para a obtenção de imagens

Figura 3-9: Contorno da seção transversal da fibra para o cálculo de sua área..... 76

Figura 3-10: Micrografias: a) seção transversal de amostra;

b) lateral da fibra natural;

c) seção transversal com morfologia diversa;

d) detalhe da estrutura interna da fibra à esquerda, onde os lúmens são visíveis.. 77

Figura 3-11: Preparação da amostra: a) a fibra deve ser centralizada

axialmente e a guia dobrada ao meio, fixando-se as partes por meio

de cola aplicada em sua área interna;

b) as bordas da guia devem ser cortadas imediatamente antes do ensaio;

c) a fibra é tracionada sem influência da guia

Figura 3-12: Setup de tração da fibra: a) aparato geral;

b) detalhe para as garras metálicas e o LVDT acoplado 
Figura 3-13: Curva tensão-deformação média da fibra de curauá.

80

Figura 3-14: Relação de perdas e ganhos de massa da fibra devido a

processos de absorção e dessorção de água

Figura 3-15: Equipamento utilizado para analisar a estrutura porosa das amostras de CCA.

Figura 3-16: Imagens obtidas da superfície do CCA: a) visão geral da

distribuição e quantidade dos poros;

b) detalhe para os poros de ar e seu formato esférico 86

Figura 3-17: Cubo de CCA centralizado na máquina de compressão, antes da aproximação do pistão

Figura 3-18: Ensaio de compressão axial: a) detalhe das dimensões e componentes do setup;

b) arranjo experimental 90

Figura 3-19: Relação tensão-deformação para corpo de provas de CCA em compressão 90

Figura 3-20: Imagem esquemática das dimensões do corpo de prova, comprimento do vão e elementos do arranjo para o ensaio de flexão a quatro pontos

Figura 3-21: Esquema de flexão a quatro pontos, com entalhe de $10 \mathrm{~mm}$ de altura e $5 \mathrm{~mm}$ de espessura 92

Figura 3-22 Setup de flexão a quatro pontos de CCA: a) sem entalhe;

b) com entalhe. 93

Figura 3-23: Relação entre força aplicada e deflexão dos corpos de prova submetidos à flexão a quatro pontos 94

Figura 3-24: Relação entre força aplicada e abertura do entalhe 95

Figura 4-1: Imagem ilustrativa da estrutura do compósito: três camadas de reforço de fibras, indicadas em ordem de disposição, intercaladas por camadas de matriz 100

Figura 4-2: Moldes utilizados para a fabricação dos compósitos. Placas de alumínio, cortadas sob medida, foram utilizadas para reduzir o comprimento dos compósitos, quando necessário 100

Figura 4-3: Processo de moldagem dos compósitos: a) camada de fibra saturada, penteada e medida;

b) disposição do tecido na matriz (dimensões para ensaio de tração); 
c) fabricação dos corpos de prova de de pull-out através da disposição

da única camada de fibra, centralizada entre duas camadas de matriz

de $4 \mathrm{~mm}$ de espessura cada

Figura 4-4: Corpo de prova para ensaio de pull-out: a) ilustração dos

elementos e dimensões dos corpos de prova;

b) corpos de provas antes e após o ensaio, nde se destacam o comprimento

livre (L livre), dividido em áreas superior e inferior, e o comprimento

arrancado da matriz (L arrancamento). O uso de cola no tecido atuou

como meio de homogeneização da área de contato das fibras

Figura 4-5: Aparato experimental de pull-out: a) ilustração 3D dos

elementos do setup;

b) vista lateral do aparato, com distinção entre o compósito restrito entre

placas de aço e o tecido excedente comprimido entre as cantoneiras

e chapas metálicas;

c) visão geral do equipamento durante o ensaio

Figura 4-6: Ensaio de tração direta dos compósitos: a) vista frontal dos

componentes do setup;

b) vista lateral, com detalhe para a espessura dos compósitos;

c) arranjo experimental utilizado.

Figura 4-7: Ensaio de flexão a quatro pontos: a) ilustração dos elementos de ensaio e suas respectivas dimensões;

b) compósito flexionado durante o teste 106

Figura 4-8: Curva típica da força de pull-out pelo deslocamento do tecido, dividida em zonas de acordo com o seu padrão de comportamento 107

Figura 4-9: Comportamento típico do compósito submetido a

ensaios e tração direta e suas respectivas zonas indicativas de seus

estágios de fissuração

Figura 4-10: Curva tensão vs deformação com detalhe para o trecho

de rigidez reduzida anterior à zona II

Figura 4-11: Modo de fissuração na tração direta: a) detalhe da formação de múltiplas fissuras na frente e no verso dos corpos de prova ensaiados;

b) ruptura e delaminação observados em algumas amostras após o ensaio

Figura 4-12: Comportamento do compósito sob flexão a quatro pontos, relação tensão $v s$ deflexão 
Figura 4-13: Modo de ruptura dos compósitos ensaiados à flexão:

a) fissuras de tração originárias na parte inferior do corpo de prova;

b) fissuras de tração com delaminação;

c) fissuras alargam-se ao longo da seção e levam o compósito à ruptura

Figura 4-14: Movimento da linha neutra ao longo do ensaio de acordo com o strain-gage inferior

Figura 5-1: Moldagem dos painéis sanduíche: à esquerda, fôrma de madeira montada ao redor do bloco de CCA, centralizado em seu interior antes da produção dos corpo de provas; à direita, painel sanduíche finalizado após a moldagem das placas de compósitos em dias consecutivos

Figura 5-2: Etapas de produção dos compósitos, em ordem: umedecimento da superfície de moldagem do bloco de CCA; disposição da primeira camada de fibras longas alinhadas de curauá sobre a matriz; última camada de matriz do compósito laminar após a disposição de três camadas de tecido como reforço.. 119 Figura 5-3: Painel sanduíche após o processo de moldagem

Figura 5-4: Elementos utilizados na análise microscópica da interface dos painéis: a) microscópio Hitachi;

b) detalhe da amostra preparada para a análise, com a superfície escurecida devido à deposição de prata 121

Figura 5-5: Dimensões e características das amostras e do disco metálico:

a) detalhe frontal do corte da perfuratriz no painel sanduíche em uma profundidade de até $5 \mathrm{~mm}$ da interface entre o compósito e o CCA;

b) dimensões do disco metálico e da rosca, cujo furo lateral superior permitiu a ligação com o equipamento de ensaio

Figura 5-6: Equipamento para a avaliação da força de aderência:

a) posicionamento do disco metálico e elementos centralizados do ensaio;

b) detalhe lateral, indicando o aparato de placas metálicas ao redor do painel

e a barra de ligação ao disco como meio de acoplamento à MTS

Figura 5-7: Corpos de prova e aparato experimental: a) vista superior do painel e suas respectivas amostras circunscritas;

b) ensaio das amostras após fixação dos discos em sua superfície, restrição do movimento do painel e centralização da aplicação de força.

Figura 5-8: Ensaio de flexão monotônico: a) configuração de 4 pontos com aplicação de força no terço médio; 
b) vista lateral do painel;

c) aparato experimental

Figura 5-9: Ilustração representativa do painel sanduíche e suas respectivas dimensões.

Figura 5-10: Ensaio cíclico dos painéis sanduíche: a) dimensões do material e elementos do setup;

b) equipamento e aparato utilizados

Figura 5-11: Imagens das amostras: a) superfície inferior do painel, demonstrando as camadas de fibra de reforço;

b) superfície superior do painel, detalhe da interface de contato entre os elementos;

c) detalhe para a superfície porosa do CCA e de sua adesão satisfatória com a argamassa 128

Figura 5-12: Micrografias da interface entre lâminas e núcleo:

a) imagem obtida pelo modo BSE demonstra uma única fase de material, sem aparentes transições;

b) imagem obtida pelo modo SE não exibe diferenças na topografia da amostra. 129

Figura 5-13: Acima, elementos presentes nas amostras do ensaio de aderência, na qual o disco, a cola, o compósito e o CCA encontram-se representados separadamente; abaixo, possíveis modos de ruptura dos painéis sanduíche no ensaio de aderência (pull-off) de acordo com a interface separada ou rompida.

Figura 5-14: Amostras ensaiadas e suas respectivas interfaces de ruptura, nas quais é possível identificar com facilidade a área de reforço de fibras nos corpos de prova extraídos

Figura 5-15: Curvas de força-deflexão de cada painel submetido à flexão e o comportamento médio de todos os corpos de prova

Figura 5-16: Divisão das zonas linear e de fissuração no comportamento dos painéis sob flexão a quatro pontos

Figura 5-17: Comparação entre o desempenho médio da estrutura sanduíche e o da referência análoga

Figura 5-18: Modos de ruptura do painel sanduíche: a) visão geral das fissuras no fim do ensaio, com fissuras de cisalhamento predominantes; 
b) detalhe do descolamento entre lâmina e núcleo, o qual pode ser associado ao efeito de pino;

c) delaminação observada nos compósitos laminares 140

Figura 5-19: Comparativo do comportamento de flexão do CCA:

a) como bloco, apresentando fissura única;

entre as lâminas do painel sanduíche, apresentando fissuras de cisalhamento ...143

Figura 5-20: Relação força-deflexão de todos os corpo de provas de painéis sanduíche e blocos de CCA submetidos à flexão a quatro pontos

Figura 5-21: Modo de ruptura das lâminas do painel sanduíche:

a) fissuras de cisalhamento no núcleo são responsáveis pela ruptura da estrutura, suscitando descolamento em relação às lâminas e gerando tensões interlaminares;

b) vista da lâmina superior do painel, com uma fissura transversal principal;

c) delaminação observada nas lâminas superior e inferior;

d) vista da lâmina inferior do painel, com a propagação de fissuras e dano pronunciado na matriz

Figura 5-22: Relação força-deflexão comparativa entre o comportamento sob flexão a quatro pontos em ensaios monotônico e cíclico.

Figura 5-23: Curva força vs deflexão dos primeiros ciclos de carregamentodescarregamento e parâmetros de análise: $\delta$ r é o deslocamento reversível, $\delta \mathrm{t}$ é o deslocamento total, $\mathrm{E}_{0}$ é a rigidez inicial do corpo de prova, $\mathrm{E}_{\mathrm{cicl}}$ é a rigidez associada ao ciclo analisado, e a área destacada é a energia dissipada no processo

Figura 5-24: Relação entre o grau de reversibilidade, $\delta \mathrm{r} / \delta \mathrm{t}$, e a deflexão normalizada, $\delta / \delta \max$

Figura 5-25: Representação das retas utilizadas para o cálculo do coeficiente angular dos ciclos de histerese, com detalhe para o comportamento dos ciclos iniciais, que apresentam maior rigidez

Figura 5-26: Relação típica entre o módulo normalizado dos ciclos e deflexão apresentada por esses.....

Figura 5-27: Relação típica entre a energia cumulativa dos ciclos de histerese, obtidos pela área entre as curvas de carregamento e descarregamento, e os pontos de deflexão dos corpo de provas 
Figura 5-28: Modos de ruptura dos corpos de prova ensaiados à flexão a quatro pontos sob carregamento cíclico:

a) multiplicação das fissuras no núcleo, com descolamento entre a lâmina inferior e o CCA;

b) detalhe para o núcleo danificado e a lâmina inferior deformada com os esforços;

c) lado inferior do painel, demonstrando a propagação das fissuras na região transversal

Figura 8-1: Curvas apresentadas pelos blocos de CCA para os ensaios de:

a) compressão axial (relação tensão-deformação);

b) flexão a quatro ponto sem entalhe (relação força-deflexão);

c) flexão a quatro pontos com entalhe (relação força-CMOD) 170

Figura 8-2: Curvas obtidas para os ensaios de: a) tração direta da fibra;

b) arrancamento do tecido;

c) tração direta do compósito;

d) flexão a quatro pontos do compósito 


\section{Lista de Tabelas}

Tabela 2-1: Compilação de propriedades químicas das fibras ............................... 32

Tabela 2-2: Propriedades físicas de fibras selecionadas......................................... 34

Tabela 2-3: Relação entre desempenho mecânico e densidade de CCA................52

Tabela 3-1: Teor variável de superplastificante e seu respectivo espalhamento ... 71

Tabela 3-2: Seção transversal dos filamentos de curauá ....................................... 76

Tabela 3-3: Propriedades mecânicas dos filamentos de curauá .............................. 80

Tabela 3-4: Características técnicas dos blocos de CCA ....................................... 83

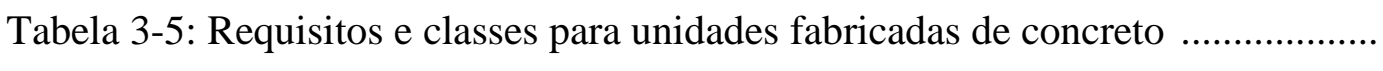

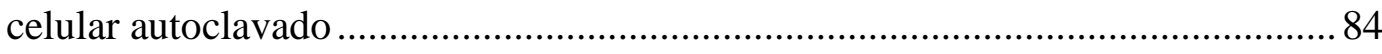

Tabela 3-6: Características físicas, densidade e umidade dos corpos de

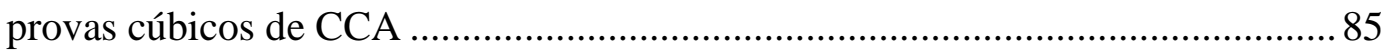

Tabela 3-7: Desempenho do CCA em ensaio à compressão ................................. 89

Tabela 3-8: Propriedades mecânicas do CCA .......................................................... 91

Tabela 3-9: Desempenho mecânico do CCA submetido ao ensaio de flexão

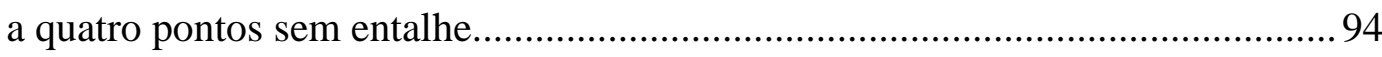

Tabela 3-10: Desempenho mecânico do CCA submetido ao ensaio de flexão .........

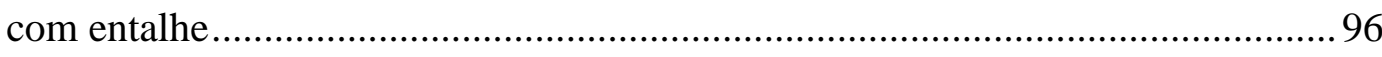

Tabela 4-1: Resumo dos resultados obtidos a partir dos ensaios de pull-out do tecido dos compósitos.

Tabela 4-2: Propriedades mecânicas dos compósitos submetidos à tração direta

Tabela 4-3: Propriedades mecânicas dos compósitos submetidos à flexão

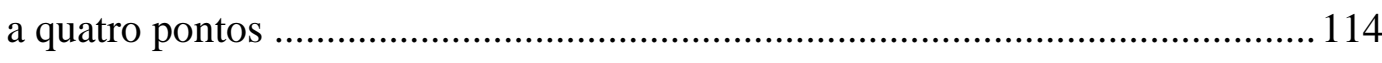

Tabela 5-1: Dimensões dos corpos de prova ..................................................... 126

Tabela 5-2: Resultados do ensaio de aderência para cada amostra ensaiada dos painéis sanduíche

Tabela 5-3: Propriedades mecânicas dos painéis sob flexão a quatro pontos (monotônico) 
Tabela 5-4: Dimensões dos painéis utilizadas para o cálculo e os valores médios da rigidez à flexão

Tabela 5-5: Forças máximas alcançadas pelos painéis e utilizadas como ponto limite do cálculo de rigidez ao cisalhamento transversal

Tabela 5-6: Dimensões de cálculo e resultados médios da resistência ao cisalhamento do núcleo

Tabela 5-8: Dimensões de cálculo e resultados médios das resistências à compressão (lâmina superior, $\mathrm{F}_{1}$ ) e à tração (lâmina inferior, $\mathrm{F}_{2}$ ) 145 
It doesn't matter what you do...so long as you change something from the way it was before you touched it into something that's like you after you take your hands away.

Ray Bradbury, Fahrenheit 451 


\section{Introdução}

\subsection{Motivação}

Haja vista o cenário mundial moderno voltado ao uso de materiais renováveis e biodegradáveis, inúmeras pesquisas focaram-se em fontes de baixo custo, grande disponibilidade e impacto ambiental reduzido. As fibras naturais apresentaram-se, então, como uma alternativa viável na Engenharia, particularmente devido às suas propriedades de resistência à tração e tenacidade, as quais tornaram-nas adequadas para a aplicação em materiais compósitos. De modo geral, o desenvolvimento de compósitos cimentícios reforçados com fibras baseiase na transferência de esforços entre o reforço e a matriz, permitindo que um sistema de microfissuras distribuídas seja criado e proporcione ganhos na ductilidade do material.

Devido à sua habilidade de controle de fissuras e aumento da resistência pós-fissuração, compósitos reforçados com fibras naturais possuem grande variedade de aplicações, tais como: reparos, smart materials, revestimentos externos em residência, emprego na indústria automobilística (partes internas de carros), painéis divisórios, fachadas, entre outros (FIDELIS, 2014; MARINELLI et al., 2008). O uso de fibras contínuas, em especial, permite a criação de elementos de concreto com pouca espessura e alta resistência à compressão e à tração (GRIES et al., 2006). Tais compósitos podem ser utilizados para fins de resistência ao impacto, retrofit, painéis estruturais e coberturas, dentre outras alternativas (COSTA CORREIA; SANTOS; SAVASTANO, 2018).

Tem-se que, apesar de as fibras sintéticas serem mais facilmente adaptáveis a aplicações específicas, além de serem produzidas em massa, o uso de fibras naturais permite a substituição de recursos não-renováveis e a construção de peças mais leves sem a perda de capacidade de carga do elemento. Outro fator importante está associado ao seu impacto ambiental, visto que a matéria prima é renovável e, ao final do seu ciclo de vida, acumula menos resíduos poluentes por ser 
biodegradável (JOSEPH et al., 1999). Ademais, as fibras estão amplamente disponíveis e requerem menor energia para extração.

Ainda sob o ponto vista da sustentabilidade, há um particular interesse da área de construção civil em reduzir as emissões de $\mathrm{CO}_{2}$ associadas à produção de cimento, principal matéria-prima do concreto, cuja tonelada é responsável por 0,08 toneladas de $\mathrm{CO}_{2}$ (GARTNER, 2004). Dessa forma, procura-se substituir parte do cimento Portland por materiais cimentícios suplementares, tais como subprodutos industriais e pozolanas, como a escória de alto forno, a cinza volante e o metacaulim (MOBASHER, 2011). Adicionalmente, as fibras naturais são beneficiadas pela incorporação desses materiais, uma vez que o ambiente alcalino da matriz cimentícia prejudica a sua durabilidade e acelera o seu envelhecimento. A decorrente degradação desse processo se dá por meio da mineralização da fibra por meio da migração de produtos de hidratação, principalmente $\mathrm{Ca}(\mathrm{OH})_{2}$, para a estrutura da fibra, comprometendo sua resistência (BENTUR; MINDESS, 1990).

Outra forma de reduzir emissões poluentes resume-se a medidas para limitar o uso de equipamentos de refrigeração, os quais liberam gases altamente tóxicos. Para fazê-lo, o uso de materiais com propriedades de isolamento térmico, como o concreto celular autoclavado (CCA), tem se mostrado eficaz sob condições térmicas variáveis (FUDGE; HACKER, 2005). O CCA é um material leve, poroso e isotrópico, cuja fabricação em massa requer menos energia, reduz a produção de resíduos e pode fazer uso de materiais reciclados de seu próprio processo de manufatura (HAAS, 2005; WITTMANN, 1983).

Há, no entanto, dificuldades e precauções associadas ao uso de fibras naturais e de concreto celular autoclavado na indústria de construção civil. No primeiro caso, deve-se considerar as dimensões das fibras, defeitos naturais, resistência, variabilidade de propriedades, cristalinidade e estrutura. Ao aplicá-las como reforço de compósitos, a interface matriz-fibras deve ser adequada e a transferência de esforços satisfatória; diferentes tipos de reforço levam a desempenhos mecânicos diferenciados. Quanto ao segundo caso, a alta porosidade e baixa densidade do CCA, associadas a baixos valores de resistência à compressão, limitam a sua aplicação para fins estruturais.

Alternativamente, construções sanduíche detêm uma natureza estrutural que permite abordagens multifuncionais e supre a necessidade da indústria por materiais 
novos, leves e de alta performance. Dentre as suas principais vantagens, encontrase a sua alta relação de rigidez por peso, derivada da distância imposta entre lâminas de considerável resistência e rigidez através da adição de um núcleo com relativa baixa resistência e densidade reduzida. Assim, elementos sanduíche são frequentemente capazes de fornecer menor peso estrutural que outras construções para uma dada condição de carregamento (VINSON, 2001; VIZZINI, 2010).

Aliados à proposta de construções com menor peso próprio, painéis sanduíche com lâminas de concreto têxtil oferecem a possibilidade de combinar seções de concreto compactas, com propriedades de rigidez e resistência. Por conseguinte, esse material detém potencial de aplicação em construções de fachada com paredes menos espessas e alta capacidade de carga, tal como coberturas, por exemplo (SHAMS; HORSTMANN; HEGGER, 2014). Ao utilizar painéis sanduíche com lâminas finas, rígidas e dúcteis, associadas a um núcleo com propriedades térmicas, torna-se possível obter sistemas construtivos eficazes sob o ponto de vista estrutural, acústico e térmico (FRAZÃO et al., 2018).

A julgar pela necessidade atual de materiais que cumpram pré-requisitos sustentáveis e exibam propriedades mecânicas satisfatórias, esta pesquisa apresenta uma alternativa na forma de painéis sanduíche, cujas lâminas fornecem ductilidade e cujo núcleo, isolamento térmico. O desenvolvimento do material procurou fazer uso de medidas a favor da durabilidade de seus constituintes, substituindo parcialmente o cimento da matriz dos compósitos, de forma a reduzir o ataque alcalino às fibras naturais. A escolha da fibra de curauá como reforço, por sua vez, justifica-se por seu uso econômico, rigidez e resistência à tração superior a algumas das fibras naturais brasileiras mais tradicionais, como o sisal e a juta (SATYANARAYANA; GUIMARÃES; WYPYCH, 2007). Outrossim, a interface fibra-matriz e lâmina-núcleo foram avaliadas para garantir que a adesão entre os materiais fosse desejável e suficiente.

\subsection{Objetivos}

Os objetivos da pesquisa em questão resumem-se a:

- Desenvolver e estudar as características de um material sustentável, leve e economicamente viável, que promova o uso de fibras naturais em substituição às 
sintéticas, fornecendo uma durabilidade satisfatória e adesão adequada entre seus componentes;

- Avaliar a aderência e o desempenho mecânico de painéis sanduíche compostos por um núcleo de concreto celular autoclavado e duas lâminas de compósitos reforçados com tecido unidirecional de curauá;

- Analisar as propriedades mecânicas isoladas dos compósitos e dos blocos de CCA, relacionando-as ao comportamento do painel e à consequente interação entre os materiais;

\subsection{Organização da Dissertação}

A estrutura do trabalho consiste nas seguintes divisões:

O Capítulo 1 apresenta a introdução, motivação e objetivos da pesquisa.

O Capítulo 2 fornece a revisão bibliográfica do tema, a qual engloba conceitos gerais e especificações a respeito de fibras naturais, concreto celular e painéis sanduíche. Trabalhos científicos são mencionados como referência, com particular ênfase no desempenho mecânico de cada material citado.

O Capítulo 3 descreve os ensaios de caracterização dos materiais de base da pesquisa, abordando os ensaios da matriz em estados fresco e endurecido, a microestrutura e resistência à tração da fibra de curauá, e a resistência à compressão e à flexão do concreto celular autoclavado.

O Capítulo 4 apresenta o método de fabricação dos compósitos reforçados com tecido unidirecional de curauá, assim como descreve a avaliação da interface fibra-matriz e da caracterização mecânica dos corpos de provas.

O Capítulo 5 traz os resultados e análises dos ensaios de aderência e de desempenho mecânico dos painéis sanduíche, avaliando a interface de transição entre lâminas e núcleo.

O Capítulo 6 apresenta as conclusões do presente trabalho e sugere meios futuros de abordagem para a continuidade e complementação da pesquisa. 


\section{Revisão da Literatura}

\subsection{Fibras Vegetais: Características Físico-químicas e Mecânicas}

As fibras naturais são, de maneira geral, divididas em três categorias de acordo com sua origem: animal, vegetal e mineral (MOHANTY; MISRA; HINRICHSEN, 2000). As fibras vegetais podem ser categorizadas de acordo com a parte da planta da qual são extraídas: semente, caule, folha e fruto. As fibras derivadas do caule possuem maior resistência à tração e, dessa forma, são utilizadas em produtos duráveis como tecido e papel, por exemplo.

Dentre as fibras vegetais mais utilizadas, encontram-se: algodão, linho, cânhamo, sisal, juta e coco (CHANDRAMOHAN; MARIMUTHU, 2011). Tais fibras são basicamente compostas por celulose, hemicelulose, lignina, cera e pectina, de forma que o efeito combinado de tais substâncias, em conjunto com sua morfologia, influencia as propriedades mecânicas da fibra vegetal e o seu desempenho associado (ROWELL et al., 2000).

Em geral, as fibras naturais detêm características favoráveis, como baixo custo, leveza e bom desempenho mecânico; são abundantes, podem ser utilizadas como isoladores térmicos e acústicos, sendo menos abrasivas para os equipamentos de processamento. Dentre suas propriedades, a densidade, resistência à tração, módulo de elasticidade, deformação do material e rigidez são características de alto interesse para a aplicação de fibras vegetais em compósitos ou para outros fins industriais.

Deve-se considerar, no entanto, que, ao contrário de fibras convencionais, as propriedades das fibras vegetais variam consideravelmente dependendo de suas características, tais como seu diâmetro, origem (caule, folha e semente) e estrutura (teor de celulose e defeitos naturais). Além disso, o seu processo de envelhecimento e as condições climáticas atuantes alteram a composição química das fibras em questão (SEDAN et al., 2008). Em virtude desses fatores, é necessário um 
conhecimento aprofundado de sua morfologia e composição de maneira a melhor compreender o seu comportamento.

\subsubsection{Morfologia}

A estrutura das fibras vegetais, também chamadas lignocelulósicas, é composta por microfibrilas de cadeias de celulose, unidas a uma matriz de lignina e hemicelulose - a qual atua como proteção mecânica e age contra a degradação microbiana. A parede celular vegetal é constituída por séries de polissacarídeos, compostos fenólicos e proteínas, sendo sua impermeabilidade e resistência fornecidas pela lignina, substância hidrofóbica que confere rigidez (TAIZ; ZIEGER, 2002).

A morfologia das fibras vegetais é constituída por diversas camadas: lamela média, parede primária e parede secundária, formadas ao redor do lúmen, o canal central responsável pelo transporte de água e nutrientes. A lamela média é composta predominantemente por pectina, a qual atua como elemento de ligação entre as fibras.

A parede primária, camada originária durante o crescimento das células, é formada por arranjos de celuloses em uma matriz de lignina, pectina e proteínas (PIETAK et al., 2007). A parede secundária, circundada pela primária, possui três camadas: parede secundária externa (S1), parede secundária intermediária (S2) e parede secundária interna (S3), como demonstrado na figura a seguir:

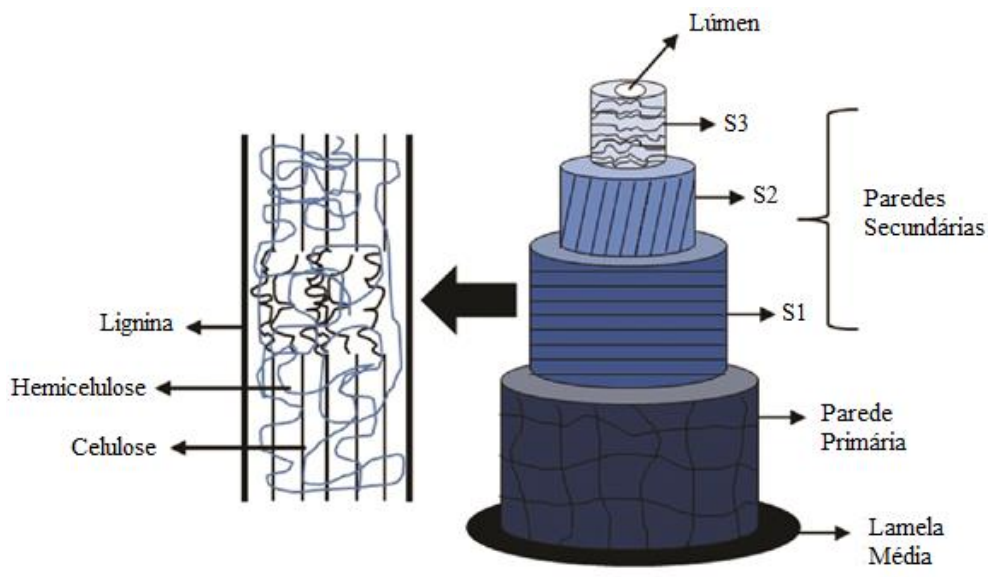

Figura 2-1: Estrutura de uma fibra vegetal, na qual S1, S2 e S3 representam as paredes secundárias externa, intermediária e interna, respectivamente. Adaptado de PEREIRA et al. (2015) 
A camada intermediária da parede secundária é constituída por microfibrilas de celulose, dispostas de forma helicoidal, com diâmetro de 10 a 30 nm (JOHN; THOMAS, 2008). Tais feixes de microfibrilas crescem no vegetal com diferentes angulações, em forma espiral.

\subsubsection{Composição Química}

A constituição básica das fibras vegetais resume-se à presença de celulose, hemicelulose, lignina, pectina e cera. A celulose é o elemento estrutural fundamental das fibras vegetais. Trata-se de um polímero de cadeia linear constituído por moléculas de glicose, unidas por ligações glicosídicas. Esses feixes de moléculas se agregam em microfibrilas, onde há a alternância entre regiões altamente ordenadas (cristalinas), estabilizadas por ligações de hidrogênio, e menos ordenadas (amorfas), nas quais as cadeias se apresentam de forma aleatória. A estrutura fibrosa da celulose é responsável pela resistência e estabilidade da fibra (PORTELA et al., 2009).

A hemicelulose é um grupo de polissacarídeos que possui diferentes unidades de açúcar, detém ramificações na cadeia e seus constituintes variam de planta para planta (ROWELL; HAN; ROWELL, 2000). Tais polímeros associamse naturalmente ao sistema de fibrilas de celulose através de ligações de hidrogênio, em paredes celulares (SANCHEZ et al., 2010).

A lignina, por sua vez, é um polímero de estrutura tridimensional, composta de hidrocarbonetos aromáticos e alifáticos, os quais unem as fibras celulósicas ao formar a parede celular (FENGEL; WEGENER, 2003). As ligações covalentes entre as cadeias de lignina e os componentes da celulose e hemicelulose aumentam a adesão entre as fibrilas, tornando a lignina um agente de enrijecimento da parede celular. De modo geral, a concentração de lignina em determinada fibra vegetal afeta sua morfologia, propriedades, maleabilidade e estrutura; seu alto teor implica em maior flexibilidade e qualidade da fibra (AGARWAL et al, 2017).

Outro elemento presente nas fibras é a pectina, nome representativo dos heteropolissacarídeos. A pectina atua na cimentação celular e fornece flexibilidade às plantas. Sua degradação implica em perda de resistência da fibra (MOHNEN, 2008). 
Em geral, a composição química da fibra varia de acordo com o seu tipo, havendo diferenças em fração de massa para cada constituinte principal, conforme demonstra a. Tabela 2-1 Tem-se que a variação composicional das fibras naturais afeta inúmeras propriedades das mesmas, desde a resistência mecânica até a estabilidade térmica e degradação. Assim, ao aplicar diferentes tipos de fibras em compósitos, esperam-se comportamentos diversos, tornando-se necessário entender as particularidades de cada fibra para o fim desejado.

Tabela 2-1: Compilação de propriedades químicas das fibras

\begin{tabular}{cccccc}
\hline $\begin{array}{c}\text { Tipo } \\
\text { de Fibra }\end{array}$ & $\begin{array}{c}\text { Celulose } \\
(\boldsymbol{\%})\end{array}$ & $\begin{array}{c}\text { Hemicelulose } \\
(\boldsymbol{\%})\end{array}$ & $\begin{array}{c}\text { Lignina } \\
(\boldsymbol{\%})\end{array}$ & $\begin{array}{c}\text { Pectina } \\
(\boldsymbol{\%})\end{array}$ & $\begin{array}{c}\text { Ceras } \\
(\boldsymbol{\%})\end{array}$ \\
\hline Bambu & $26,0-65,0$ & 30,0 & $5,0-31,0$ & - & - \\
Cânhamo & $68,0-78,0$ & $15,0-22,0$ & $3,7-10,0$ & 0,9 & 0,8 \\
Curauá & $70,7-73,6$ & 9,9 & $7,5-11,1$ & - & - \\
Coco & $21,46-53,0$ & $0,2-20,0$ & $38,3-46,5$ & $3,0-4,0$ & - \\
Juta & $51,0-72,0$ & $12,0-22,1$ & $5,0-15,9$ & $0,2-0,4$ & 0,5 \\
Linho & $60,0-81,0$ & $14,0-20,6$ & $2,0-5,0$ & $1,8-2,3$ & $1,5-1,7$ \\
Piaçava & $28,6-31,6$ & 25,8 & $45,0-48,4$ & - & - \\
Sisal & $43,0-88,0$ & $10,0-14,2$ & $4,0-14,0$ & $0,8-10,0$ & 2,0 \\
\hline
\end{tabular}

Fonte: adaptado de: BIAGIOTTI et al. (2004); DITTENBER et al. (2012); PACHECO-TORGAL et al. (2011); SATYANARAYANA et al. (2007)

\subsubsection{Propriedades Mecânicas}

As propriedades mecânicas das fibras naturais detêm grande variabilidade, estando sujeitas a inúmeras influências desde seu cultivo até sua morfologia. No primeiro caso, fatores como clima local, colheita, modo de extração, parte originária da planta e fornecimento devem ser considerados. Em termos morfológicos, características como geometria, seção transversal e estrutura cristalina são relevantes para o comportamento da fibra (DITTENBER; GANGARAO, 2012).

A composição química da fibra utilizada é igualmente importante, uma vez que a tenacidade da mesma é atribuída à rigidez das cadeias de celulose e à sua estrutura cristalina. Isso se dá pois as microfibrilas alinham-se ao eixo das fibras 
quando uma força é aplicada. A ruptura de uma fibra ocorre quando se perde a união entre um elemento da matriz (composta de lignina e hemicelulose) e as microfibrilas de celulose, as quais igualmente perdem as ligações de hidrogênio presentes no processo. Logo, a resistência à tração está ligada diretamente à força das cadeias de celulose, as quais atuam como elementos de reforço (HÄNNINEN, 2011).

Segundo o estudo de Bledzki e Gassan (1999), há a indicação de uma alta correlação entre a rigidez das fibras e a diminuição do ângulo espiral em relação ao eixo das mesmas, uma vez que tal ângulo está relacionado ao módulo de elasticidade. Assim, quanto mais alinhada a fibra estiver, maior sua rigidez. Dessa forma, torna-se conveniente medir o alinhamento das microfibrilas para a análise das propriedades de tração, levando-se em consideração a anisotropia das propriedades mecânicas das fibras vegetais.

Além disso, aspectos físicos como comprimento, formato e diâmetro da fibra influenciam em seu desempenho mecânico. Fibras com alta relação de comprimento/espessura tendem a apresentar resistência à tração mais elevada. Contudo, estudos diversos, como os de Tomczak et al. (2007) e Savastano Jr (2000), demonstraram que um maior comprimento da fibra pode levar a uma redução de sua resistência, uma vez que os defeitos e as irregularidades próprios de fibras vegetais detêm maior probabilidade de ocorrerem nesses casos do que em fibras mais curtas. Tais imperfeições comprometem a resistência e podem levar a uma ruptura precoce.

A influência do diâmetro das fibras em propriedades mecânicas possui certa disparidade de resultados: nos estudos realizados por Mukherjee e Satyanarayana (1986) em fibras de sisal, assim como na pesquisa de fibras de banana por Kulkarni et al. (1983), não foram observadas mudanças significativas no desempenho das fibras a partir do aumento de seu diâmetro. Não obstante, Tomcazk et al. (2007) demonstraram que a variação do diâmetro de fibras de curauá, medindo entre 26 e $64 \mu \mathrm{m}$, levou a diferenças consideráveis na resistência à tração e módulo de elasticidade das amostras: maiores diâmetros implicaram na redução de ambas as propriedades. De igual modo, a análise do comportamento de fibras de linho, realizada por Baley (2002), demonstrou um decréscimo do módulo de elasticidade de acordo com o aumento do diâmetro da fibra. $\mathrm{O}$ autor relacionou o resultado à consideração do tamanho do lúmen na seção transversal das fibras analisadas. 
Adicionalmente, devido à natureza higroscópica das fibras, o teor de umidade influencia em sua resistência à tração e contribui para sua degradação, nomeadamente em ambientes alcalinos (METHACANON et al., 2010). Valores representativos de propriedades das fibras associadas ao desempenho mecânico podem ser encontradas na Tabela 2-2.

Tabela 2-2: Propriedades físicas de fibras selecionadas

\begin{tabular}{cccccc}
\hline $\begin{array}{c}\text { Tipo } \\
\text { de }\end{array}$ & $\begin{array}{c}\text { Diâmetro } \\
\text { Fibra }\end{array}$ & $\begin{array}{c}\text { Resistência } \\
\text { à Tração } \\
(\mathbf{M P a})\end{array}$ & $\begin{array}{c}\text { Módulo de } \\
\text { Elasticidade } \\
(\mathbf{G P a})\end{array}$ & $\begin{array}{c}\text { Ângulo } \\
\text { Micro- } \\
\text { fibrilar } \\
\left({ }^{\circ}\right)\end{array}$ & $\begin{array}{c}\text { Umidade } \\
(\boldsymbol{\%})\end{array}$ \\
\hline Bambu & $25,0-40,0$ & $106,0-800,0$ & $11,0-32,0$ & - & - \\
Cânhamo & $25,0-500,0$ & $270,0-900,0$ & $23,5-90,0$ & $2,0-6,2$ & $6,2-12,0$ \\
Curauá & $7,0-10,0$ & $117,0-3000,0$ & $11,8-96,0$ & - & - \\
Coco & $10,0-460,0$ & $95,0-230,0$ & $2,8-6,0$ & $30,0-49,0$ & 8,0 \\
Juta & $20,0-200,0$ & $320,0-800,0$ & $8,0-78,0$ & 8,0 & $12,5-13,7$ \\
Linho & $12,0-600,0$ & $343,0-2000,0$ & $26,0-103,0$ & $5,0-10,0$ & $8,0-12,0$ \\
Piaçava & - & $109,0-1750,0$ & $1,1-6,0$ & - & - \\
Sisal & $8,0-200,0$ & $287,0-913,0$ & $9,0-38,0$ & $10,0-22,0$ & $10,0-22,0$ \\
\hline \multicolumn{4}{c}{ Fonte: adaptado de DITTENBER et al. $(2012) ;$ MONTEIRO et al. $(2011)$} &
\end{tabular}

\subsection{Compósitos Reforçados com Fibras}

A definição básica e comumente utilizada de compósitos é a de um material formado por dois outros materiais distintos, que, após combinação, resulta em um novo produto com características e propriedades aperfeiçoadas em relação aos seus componentes originais. Assim, trata-se de um material formado por uma fase contínua, denominada matriz, e uma fase dispersa, denominada reforço ou modificador, a qual pode ser contínua ou não na estrutura do mesmo.

A base do comportamento mecânico de um compósito se dá por meio da transferência de tensões entre matriz e reforço, cujo mecanismo influencia na resistência, modo de ruptura e deformação última do material. Em aplicações de compósitos cimentícios reforçados com fibras, a capacidade de deformação da matriz é inferior à das fibras, de forma que aquela rompe antes que a plena capacidade do reforço seja atingida. Em seguida, as fibras interceptam as fissuras, 
como pontes, contribuindo para a dissipação de energia por meio do processo de arrancamento e descolamento (MOBASHER, 2011).

Dessa forma, no caso de matrizes frágeis, a incorporação de materiais fibrosos possui vantagens consideráveis em relação à redução do tamanho das fissuras e ao ganho de resistência pós-fissuração, reduzindo a possibilidade de ruptura brusca do elemento. O estudo da interação entre matriz e fibras, tal como das variáveis englobadas por essa relação, constitui o objeto de análise dessa seção.

\subsubsection{Fatores de Desempenho}

O desempenho de compósitos reforçados com fibras é influenciado por uma série de fatores, dentre os quais pode-se destacar: a morfologia das fibras acrescidas na matriz; a orientação e a quantidade de fibras na estrutura do compósito; a interface matriz-fibra e a transferência de tensões (HULL; CLYNE, 1996).

\section{- Interface Matriz-fibras}

A matriz é um material homogêneo, que mantém a integridade estrutural do compósito ao aglutinar o material de reforço, preencher espaços vazios e manter os constituintes em suas posições. A escolha da matriz, assim como de seu reforço, depende das condições de uso do compósito, da vida útil dos constituintes, das ações mecânicas atuantes, dentre outros fatores.

No caso de matrizes cimentícias, deve-se haver um cuidado particular no caso de reforço com fibras naturais, uma vez que, devido à sua natureza e às propriedades da pasta de cimento, a interação entre reforço-matriz pode levar à possível perda precoce de resistência do compósito. Estudos (TOLÊDO FILHO et al., 2000; SAVASTANO; AGOPYAN, 1999) demonstram que os principais fatores motivadores estão relacionados a três condições mais frequentes. $\mathrm{O}$ fator predominante está associado à degradação das fibras por meio do ambiente alcalino da pasta de cimento. Há, igualmente, a mineralização das fibras em virtude da migração de hidróxido de cálcio para as suas paredes celulares. Adicionalmente, as fibras podem sofrer variações dimensionais por influência da umidade, as quais prejudicam a ligação fibra-matriz. 
De maneira a manter a durabilidade do compósito e evitar a degradação das fibras, algumas medidas podem ser adotadas tanto em relação à matriz quanto ao reforço. Para a primeira, a adição de materiais pozolânicos (sílica ativa, cinza volante ou escória, por exemplo) mostra-se particularmente eficiente, assim como o uso de cimentos com alto teor de alumina, uma vez que se consome o hidróxido de cálcio e se reduz a alcalinidade da pasta de cimento (TOLÊDO FILHO et al., 2000). Adicionalmente, tratamentos na superfície das fibras podem agir em sua capacidade de absorção de água, evitando seu aumento dimensional e, por consequência, aprimorando sua compatibilização com a matriz (CANOVAS; SELVA; KAWICHE, 1992; JOHN et al., 2005)

\section{- Orientação e Fração Volumétrica das Fibras}

A disposição e quantidade das fibras presentes em um compósito têm alta correlação com o seu comportamento e desempenho apresentados. Ao todo, um aumento na fração volumétrica da fibra leva a um aprimoramento da resistência à tração em uma variedade de sistemas de reforço de fibras. Inúmeros estudos (POTHAN; THOMAS; GEORGE, 1999; POTHAN; OOMMEN; THOMAS, 2003) comprovam que a relação entre a resistência do compósito e seu volume de fibras é direta e determinante.

Entretanto, tipos diferentes de fibra podem gerar efeitos opostos no comportamento do compósito dependendo do volume de reforço. Zaman et al. (2009) avaliaram o desempenho mecânico estático e dinâmico de compósitos reforçados com fibra de coco, com fração volumétrica de até $15 \%$, em matriz polimérica. Ambas as propriedades se mostraram dependentes da quantidade de fibra, havendo um decréscimo de resistência para um maior volume de fibras - o que indica que a transferência de esforços matriz-fibras não foi eficaz. Frações elevadas podem igualmente prejudicar o embebimento adequado das fibras na matriz.

O arranjo das fibras, por sua vez, é definido por dois principais fatores: as formas das fibras individuais e sua dispersão na matriz. Tem-se dois tipos principais de reforço: contínuo, no qual fibras longas são incorporadas na matriz de forma ininterrupta ao longo de todo o compósito; descontínuo, composto por fibras curtas, 
usualmente menores do que $50 \mathrm{~mm}$, dispersas na matriz (BENTUR; MINDESS, 1990). A orientação das fibras na matriz é igualmente um fator importante: podese dispô-las de maneira aleatória ou alinhada de acordo com uma direção preferencial. Há, igualmente, os arranjos 2D e 3D.

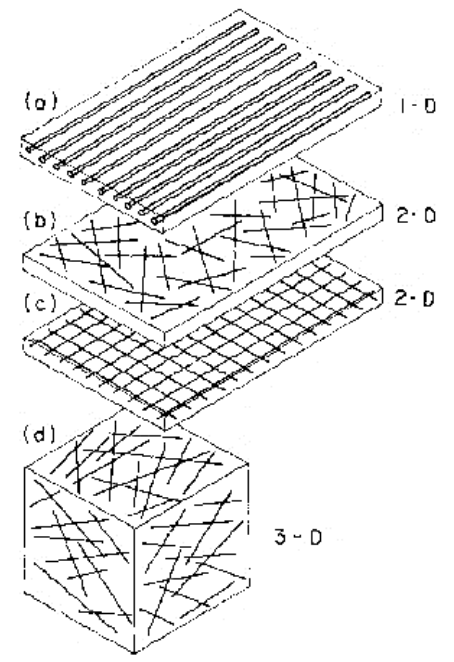

Figura 2-2: Arranjo de fibras longas (a,c), dispostas ao longo da matriz de forma contínua, e fibras curtas (b,d), dispersas na matriz. Fonte: BENTUR e MINDESS (1990)

Kang e Kim (2011) investigaram o efeito da orientação das fibras em estado de pré e pós-fissuração de compósitos cimentícios de elevado desempenho reforçados com fibras (UHPFRCC). A partir de ensaios de tração, observou-se que a orientação do reforço tem um efeito considerável no estado de pós-fissuração: a resistência à tração de compósitos com reforço contínuo distribuído longitudinalmente mostrou-se superior aos corpos de provas com fibras longas na direção transversal e fibras curtas distribuídas aleatoriamente em arranjos 2D e 3D.

Isso se deve ao fato de que o compósito detém propriedades anisotrópicas e o efeito de reforço das fibras é determinante. Em casos em que a seção longitudinal das fibras é disposta na mesma direção dos esforços de tração, eleva-se ao máximo a transmissão de esforços; no caso da disposição transversal, o reforço é ineficaz e as fibras atuam como defeitos na matriz, levando a trincas em tensões muito baixas. Usualmente, a forma mais eficiente de se obter um alto desempenho é utilizando fibras contínuas, já que os esforços serão mais bem distribuídos e resistidos através de um mesmo elemento ininterrupto (PELED; BENTUR, 2000). 


\section{- Transferência de Tensões}

Em geral, a transferência de tensões da matriz às fibras ocorre a partir da combinação de cisalhamento interfacial e ligação de natureza mecânica entre a fibra e a matriz. Até o ponto de fissura dessa última, a carga é suportada tanto pela matriz quanto pelas fibras. Uma vez que a fissuração ocorra, as fibras passam a suportar a tensão total na seção fissurada, agindo como pontes de ligação entre as regiões fissuradas da matriz, até que sejam completamente arrancadas nesse processo.

Ao permitir um meio de transferência de tensões e cargas ao longo das fissuras, as fibras podem aprimorar o desempenho mecânico do compósito, apresentando dois comportamentos principais: o strain-hardening e o strainsoftening. O primeiro é caracterizado por um ganho de resistência pós-fissuração, geralmente acompanhado por um comportamento de múltipla fissuração. De acordo com Bentur e Mindess (1990), uma fração volumétrica superior a 2\% tende a proporcionar maior capacidade de carga ao compósito e levar à condição de strain hardening.

O comportamento de strain-softening, por sua vez, ocorre quando há perda de resistência e a curva tensão-deformação apresenta-se de forma decrescente. Esse caso ocorre mais frequentemente com fibras curtas $(<50 \mathrm{~mm})$, uma vez que a fibra não atravessa o comprimento do material compósito como um todo e a distribuição de tensões não se dá de forma homogênea. Assim, a ligação matriz-reforço não é capaz de transmitir perfeitamente os esforços gerados na matriz, os quais deverão ser conduzidos por meio de deformação plástica ou elástica da matriz.

\subsubsection{Compósitos Cimentícios Reforçados com Fibras Naturais}

Há inúmeras maneiras de se utilizar as fibras naturais como reforço: fibras curtas, longas (tecido), nanofibras e polpa. Dentre os objetivos de adicioná-las em compósitos cimentícios, encontra-se o aprimoramento do seu desempenho mecânico, como o seu comportamento sob tração, flexão e impacto, além de melhorias nas propriedades de ductilidade e tenacidade pós-fissuração (YAN; KASAL; HUANG, 2016). 
Fibras curtas são frequentemente utilizadas em compósitos, o que resulta em produtos mais adequados a aplicações não estruturais, devido ao seu comportamento de strain softening e menor resistência à tração (SILVA; MOBASHER; FILHO, 2009a). Ensaios de tração, compressão e flexão foram realizados por Lima (2004) em compósitos cimentícios com reforço discreto de fibras de sisal, em corpos de prova com 1-3\% de fração volumétrica. A tensão máxima pós-fissuração demonstrou-se proporcional ao volume de fibras, alcançando 0,32 $\mathrm{MPa}, 0,74 \mathrm{MPa}$ e 1,19 $\mathrm{MPa}$ para adições de 1\%, 2\% e 3\%, respectivamente. Em ensaios de flexão a quatro pontos, os compósitos apresentaram deflexão última superior a $3 \mathrm{~mm}$, demonstrando ganho de tenacidade.

Similarmente, a influência do volume utilizado de fibras foi verificada por Sedan et al.(2008) a partir de compósitos cimentícios reforçados com fibras curtas de cânhamo. Observou-se um aumento na resistência à flexão a partir de volumes crescentes de fibras, obtendo-se uma resistência máxima de 6,8 MPa com a fração ótima de $16 \%$. Contudo, frações volumétricas superiores, de até $20 \%$, geraram falta de homogeneidade na mistura e menor adesão entre fibra-matriz, levando a uma redução da resistência.

No caso de compósitos reforçados com fibras curtas de juta, Mansur e Aziz (1982) verificaram a influência das variações de volume (1-4\%) e comprimento das fibras $(12,18,25$ e $38 \mathrm{~mm})$ por meio de ensaios de tração direta, flexão, compressão axial e impacto. A partir do volume ótimo de $2-3 \%$ e $25 \mathrm{~mm}$ de comprimento, observou-se um ganho substancial nas resistências à tração, à flexão e ao impacto. Não houve, contudo, diferença considerável na resistência à compressão ou sequer no módulo de elasticidade em tração e compressão. Ao todo, o desempenho mecânico mostrou-se adequado para materiais de construção de baixo custo. $\mathrm{O}$ mesmo foi concluído pela pesquisa de Swift (2011) com fibras curtas de sisal em área rural.

Compósitos cimentícios reforçados com fibras curtas de curauá apresentam performance usualmente satisfatória, como demonstra o estudo de Picanço (2005), no qual os corpos de prova demonstraram alta ductilidade e resistência pósfissuração, particularmente em comparação a compósitos reforçados com outras fibras vegetais, como sisal, coco e juta. Adicionalmente, a pesquisa de Soltan et al. (2017) demonstra que compósitos cimentícios com comportamento strain 
hardening podem ser obtidos com reforço discreto de fibras de curauá. Testes prévios realizados durante a pesquisa demonstraram que volumes de fibra abaixo de $2 \%$ apresentavam comportamento de strain softening e não foram suficientes para uma condição de múltipla fissuração. Ao fim dos ensaios, compósitos cimentícios reforçados com fibras curtas de 10-20 mm de curauá, com fração volumétrica ótima de 4,4\% e variações composicionais da matriz, alcançaram desempenho mecânico satisfatório e ganho de resistência pós-fissuração.

Do mesmo modo, o desempenho mecânico de compósitos com fibras discretas de curauá foi avaliado por meio de ensaios de flexão a quatro pontos por d'Almeida et al. (2010). De maneira a evitar o processo de mineralização das fibras, $50 \%$ do cimento Portland foi substituído por metacaulim. Compósitos reforçados com 2,4 e $6 \%$ de fibras curtas, de comprimentos de $25 \mathrm{~mm}$ e $50 \mathrm{~mm}$, foram testados. Para fibras de $25 \mathrm{~mm}$, observou-se um aumento na resistência à flexão pósfissuração de 33,44\% e 41,48\% quando a fração volumétrica aumentou de 2 para $4 \%$ e de 4 para $6 \%$, respectivamente. Aumentos similares foram observados para $50 \mathrm{~mm}$ entre $2 \%$ e $4 \%$. Em termos de tenacidade, o maior valor para fibras de 25 $\mathrm{mm}$ foi de $1,59 \mathrm{~kJ} / \mathrm{m}^{2}$, e $2,13 \mathrm{~kJ} / \mathrm{m}^{2}$ para $50 \mathrm{~mm}$ - ambas correspondentes à maior fração volumétrica. Os compósitos com $50 \mathrm{~mm}$ e $4 \%$ de reforço apresentaram resistência pós-fissuração de 4,59 ( \pm 0,58) MPa e comportamento strain hardening.

Os compósitos reforçados com tecido, por outro lado, constituem-se como uma inovação importante, que permite que estruturas leves e de pouca espessura detenham uma alta resistência à tração e à compressão a partir da eficiência de seu reforço. Compósitos cimentícios reforçados com tecido de sisal, com alta resistência à tração e ductilidade, foram desenvolvidos por Silva et al.(2009b). Os corpos de prova detinham fração volumétrica de $10 \%$ e foram submetidos a testes de tração e flexão. Os compósitos apresentaram alto módulo de elasticidade, entre 30 e $34 \mathrm{GPa}$, para os ensaios de flexão e tração, respectivamente. Um comportamento caracterizado pela formação de múltiplas fissuras foi observado, apresentando uma resistência máxima de aproximadamente $12 \mathrm{MPa}$ para tração e 25 MPa para flexão. Alta capacidade de absorção de energia foi verificada por meio da tenacidade, com valores de 45 e $22 \mathrm{~kJ} / \mathrm{m}^{2}$ em tração e flexão, respectivamente.

Compósitos cimentícios têxteis com camadas de fibra de juta foram desenvolvidos por Fidelis (2014), com matriz com baixo teor de hidróxido de cálcio 
e tratamento superficial com polímero nas fibras. Ensaios de tração direta em compósitos reforçados com 5 camadas apresentaram tensão última de $7 \mathrm{MPa}$ e deformação de $6,5 \%$.

Melo Filho (2005) desenvolveu laminados cimentícios reforçados por 3 e 5 camadas de fibras de sisal e moldados sob pressões de 2, 3 e $4 \mathrm{MPa}$, de maneira a analisar a influência do volume de fibras, fração volumétrica e pressão de moldagem. As características ótimas de pressão de moldagem de $3 \mathrm{MPa}$, fração volumétrica de $6 \%$ de fibras e 5 camadas de reforço de sisal levaram a uma resistência à flexão máxima de $40 \mathrm{MPa}$ e uma resistência à tração direta de $16 \mathrm{MPa}$. Outro estudo com compósitos reforçados com fibras longas de sisal foi realizado pelo mesmo autor, Melo Filho (2012), no qual elementos com reforço unidirecional e bidirecional, com 4, 6 e 8\%, obtiveram comportamento satisfatório no ensaio de punção, aumentando a carga de ruptura e tenacidade dos corpo de provas.

Em termos de durabilidade de compósitos cimentícios com fibras naturais, Toledo Filho et al. (2009) analisaram o comportamento de compósitos reforçados com fibras longas de sisal e matriz modificada, a partir do efeito de envelhecimento acelerado e ensaios de flexão a quatro pontos. O uso de uma matriz composta de $50 \%$ de argila calcinada como substituição parcial do cimento Portland levou ao consumo de hidróxido de cálcio e evitou o processo de degradação das fibras, mantendo a sua resistência após os ciclos de molhagem e secagem.

A influência da pressão de moldagem na resistência de compósitos foi avaliada por d'Almeida et al. (2009) em corpos de prova reforçados com cinco camadas de fibras longas e alinhadas de curauá, com $6 \%$ de fração volumétrica. Parte do cimento Portland foi substituído por metacaulim com o objetivo de produzir uma matriz livre de hidróxido de cálcio. De maneira a avaliar o seu comportamento mecânico, testes de flexão a quatro pontos foram realizados em corpos de prova de $400 \mathrm{~mm}$ x $100 \mathrm{~mm}$ x $12 \mathrm{~mm}$. Os compósitos sem pressão de moldagem alcançaram resistência à flexão de 27,52 MPa e tenacidade de 29,13 $\mathrm{kJ} / \mathrm{m}^{2}$. Os corpos de prova com pressão de $3 \mathrm{MPa}$ obtiveram $23,70 \mathrm{MPa}$ e 26,21 $\mathrm{kJ} / \mathrm{m}^{2}$, respectivamente. Logo, o efeito da aplicação de pressão durante a moldagem mostrou-se prejudicial para a resistência à flexão.

Os mecanismos de fissuração e o desempenho mecânico de compósitos reforçados com tecido de curauá, com variação do número de camadas (1, 3 e 5), 
foram avaliados através de ensaios de tração direta e de flexão a quatro pontos (SOUZA; SOUZA; SILVA, 2018). Todos os tipos de compósito apresentaram comportamento de strain e deflection hardening, havendo a formação de pequenas fissuras, inferiores a $70 \mu \mathrm{m}$.

Uma outra opção vantajosa para elementos compósitos encontra-se no uso de nanofibras. O objetivo de utilizar reforços na escala nanométrica resume-se a eliminar os defeitos macroscópicos a partir da desintegração de fibras naturais e eventual separação de fibrilas altamente cristalinas com poucos defeitos. Ao mudar as dimensões da fase de reforço, a área específica é consideravelmente aumentada, ao passo que a distância média entre as partículas diminui, permitindo interações partícula-partícula (DUFRESNE; BELGACEM, 2013).

Além das alternativas prévias, pode-se utilizar a polpa das fibras como reforço de compósitos, sendo necessária a individualização das fibras celulósicas antes de sua incorporação na matriz. Tal processo de desfibramento da planta em forma de massa fibrosa é denominado "polpação" e pode ser realizado por meio de ação mecânica e/ou química. Nesse último caso, visa-se dissolver a lignina e a hemicelulose por meio de ataques alcalinos, degradando os componentes não celulósicos.

De acordo com estudos, a redução do conteúdo de lignina torna as fibras mais resistentes ao ataque alcalino da pasta de cimento, provando-se benéfica para a durabilidade de compósitos cimentícios (GRAM, 1983). Compósitos cimentícios reforçados com polpa lignocelulósica apresentaram resultados satisfatórios, como os de Savastano et al. (2000), com reforço de fibras como banana e Eucalyptus grandis, e de Savastano et al. (2003), com reforço de polpa de sisal.

\subsection{Concreto Celular}

O concreto leve define-se como um material com densidade inferior ao concreto convencional $\left(2200-2600 \mathrm{~kg} / \mathrm{m}^{3}\right)$, possuindo uma variação entre $300-1850$ $\mathrm{kg} / \mathrm{m}^{3}$. Tal diferença implica em certos benefícios, como melhor isolamento térmico, menor peso próprio dos elementos construtivos e uma redução correspondente no tamanho das fundações. A densidade do concreto é reduzida por meio da substituição parcial dos materiais sólidos por vazios - os quais podem ser 
inseridos por meio de três possíveis formas: nas partículas de agregados (concreto de agregado leve), na pasta de cimento (concreto celular) e entre os agregados graúdos (concreto sem finos) (NEVILLE, 2011).
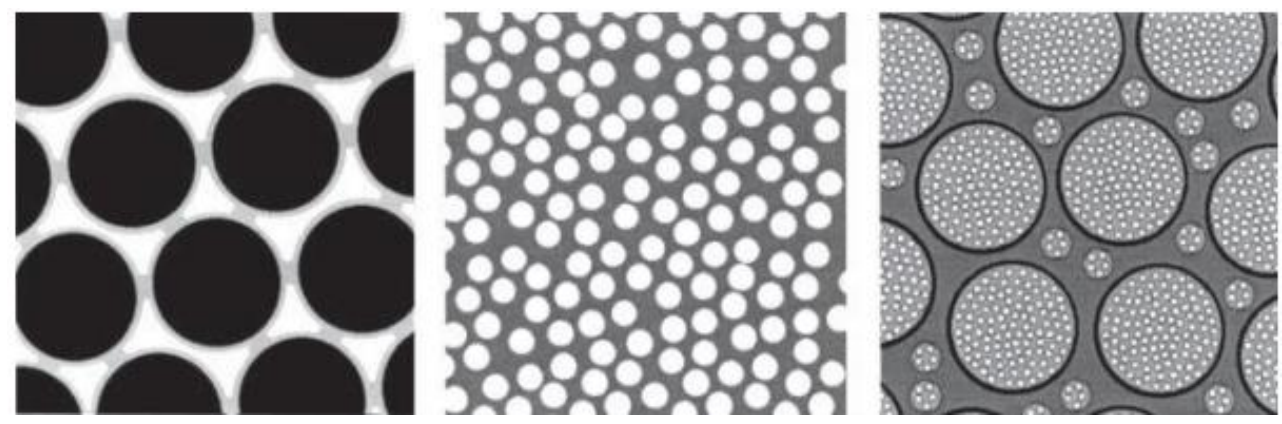

Figura 2-3: Concreto sem finos, concreto celular e concreto de agregado leve, respectivamente. Fonte: NEWMAN e CHOO (2003)

O concreto celular, em particular, é usualmente constituído por cimento, cal, areia silicosa, água e, por vezes, materiais pozolânicos. A sua estrutura porosa, responsável por sua baixa densidade e desempenho térmico adequado, se dá por meio da adição de um agente introdutor de vazios. Inúmeras vantagens podem ser observadas em seu uso, nomeadamente:

i. Devido à sua baixa densidade, sua estrutura facilita o manuseio e o corte, agilizando o processo de construção;

ii. Alto conteúdo de poros, de aproximadamente $80 \%$ de sua estrutura, permite que $5 \mathrm{~m}^{3}$ de material possam ser produzidos através de $1 \mathrm{~m}^{3}$ de materiais base, de maneira que há menor consumo de matéria-prima e maior leveza (HAAS, 2005);

iii. Alta capacidade de isolamento térmico devido ao seu baixo peso específico, associado ao seu coeficiente de condutividade entre 0,1 e $0,22 \mathrm{~W} / \mathrm{m} . \mathrm{K}$ para densidades entre $300-700 \mathrm{~kg} / \mathrm{m}^{3}$ (WITTMANN, 1983). Inúmeros estudos acerca do desempenho térmico de concretos celulares foram desenvolvidos (GAWIN et al., 2004; JIN et al., 2016; STUCKES; SIMPSON, 1985). Sua condutividade térmica demonstra-se mais condicionada à variação de umidade do que ao aumento de temperatura: quanto maior a umidade, maior a capacidade de condução de calor (JERMAN et al., 2013; LAURENT; GUERRE-CHALEY, 1995); 
iv. Resistência ao fogo, conforme demonstram testes realizados sob diferentes condições de umidade $\left(3\right.$ a $5 \%$ ) e temperatura $\left(100^{\circ} \mathrm{C}, 300^{\circ} \mathrm{C}, 500^{\circ} \mathrm{C}, 700^{\circ} \mathrm{C}\right.$, $900^{\circ} \mathrm{C}$ e $\left.1000^{\circ} \mathrm{C}\right) . \mathrm{O}$ concreto celular autoclavado evidencia perda de massa e propriedades mecânicas a partir de temperaturas acima de $500^{\circ} \mathrm{C}$ (KEYVANI, 2014);

v. Técnicas de produção eficientes em termos de energia e com menor demanda de quantidade básica de materiais em comparação com outros elementos de construção (DOMINGO, 2008). Além disso, no caso do concreto celular autoclavado, as emissões de gases como $\mathrm{CO}_{2}, \mathrm{CO}, \mathrm{NO}_{\mathrm{x}}$, originárias da geração de vapor no processo de produção, são relativamente baixas em comparação com outros processos industriais usuais (RILEM, 1993);

vi. Uso sustentável devido ao seu caráter não-tóxico, poroso, reutilizável, renovável e reciclável (LIU et al., 2001; RATHI; KHANDVE, 2015).

Dentre as suas desvantagens, encontram-se o seu alto teor de umidade, menor resistência e maior tendência à retração em comparação com o concreto padrão. Tais propriedades, no entanto, podem ser aprimoradas por meio da cura em autoclave (HOLT; RAIVIO, 2005). Além disso, o coeficiente de absorção sonora de concretos leves é usualmente baixo, exceto em casos de tratamento especial. Estudos com três tipos diversos de concreto celular autoclavado demonstram que o coeficiente de permeabilidade de ar decresce conforme a densidade do material aumenta (LAUKAITIS; FIKS, 2006). Em contraposição, o concreto celular espumoso oferece maior isolamento acústico quando comparado ao concreto usual devido à sua microestrutura em forma de células (AMRAN; FARZADNIA; ALI, 2015).

\subsubsection{Classificação}

De acordo com Narayanan e Ramamurthy (2000a), o concreto celular é classificado de acordo com três categorias principais: o método de formação de poros, o tipo de ligante e o método de cura. Os poros são formados por meio de processos químico, mecânico ou intermediário (pó de alumínio e resina). Os 
principais ligantes são cimento ou cal, podendo haver substituição parcial desses por materiais pozolânicos. O método de cura resume-se em autoclavado e nãoautoclavado (cura úmida), afetando o desempenho mecânico final do material. Dentre tais categorias, destacam-se o concreto celular autoclavado e o concreto celular espumoso, diferenciados por seu método de produção, como demonstrado abaixo:

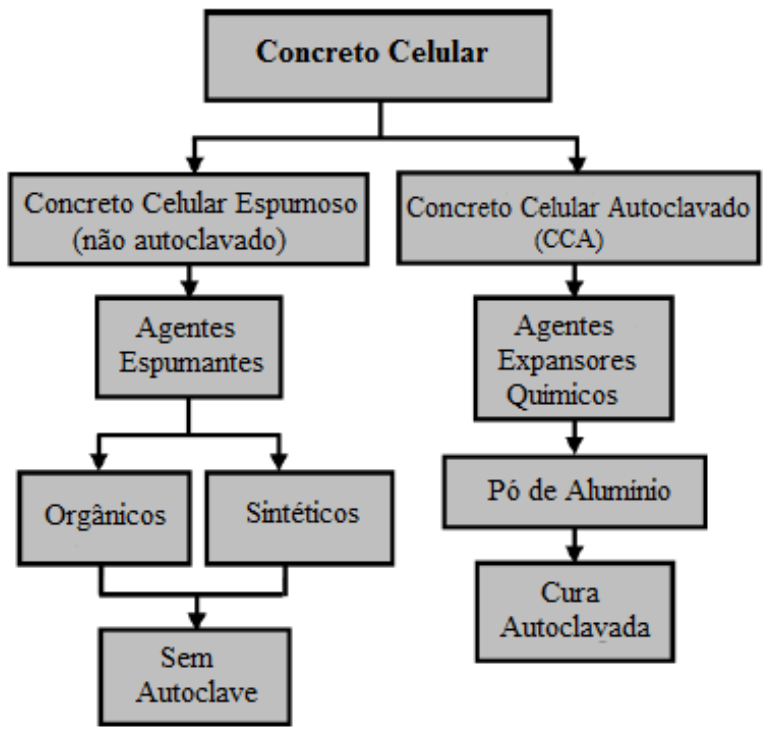

Figura 2-4: Classificação do concreto celular. Adaptado de HAMAD (2014)

O concreto celular autoclavado (CCA) é um material leve, de densidade seca entre 200 e $1000 \mathrm{~kg} / \mathrm{m}^{3}$, detentor de baixa condutividade térmica e alta resistência ao calor. A sua estrutura porosa é produzida através de um processo mecânico, por introdução de vazios, ou químico aerador, por meio de agentes expansores - sendo o pó de alumínio o mais utilizado para esse fim (RILEM, 1993). A reação química resultante do contato do agente expansor com substâncias alcalinas libera hidrogênio, expandindo o volume da mistura e, consequentemente, criando poros.

$\mathrm{O}$ concreto celular espumoso, em contrapartida, utiliza agentes espumantes para introduzir vazios em sua matriz. Os agentes mais comuns são os sintéticos e à base de proteínas. Esses últimos permitem a inclusão de uma maior quantidade de ar, além de fornecerem um sistema de poros geralmente mais estável; os agentes sintéticos produzem maior expansão e, portanto, produzem um material com menor densidade. Em geral, a quantidade inserida de agente espumante detém efeito 
considerável nas propriedades do concreto fresco e endurecido (AMRAN; FARZADNIA; ALI, 2015).

\subsubsection{Microestrutura}

As propriedades microestruturais do concreto celular são significantemente alteradas a partir de variações em sua composição ou em seu método de cura - os quais, por sua vez, estão diretamente ligados ao tamanho e distribuição de poros do material. Ademais, a porosidade detém influência considerável na resistência, permeabilidade, difusividade, retração e fluência do concreto celular (NARAYANAN; RAMAMURTHY, 2000a).

A estrutura porosa do concreto celular pode ser dividida em três regiões: poros de ar introduzidos por agentes surfactantes, com raio de 50 a $500 \mu \mathrm{m}$; microporos de raio $50 \mathrm{~nm}$ ou inferior, situados no espaço entre os produtos de hidratação e a pressão de ar; macroporos, externos a essas regiões, com poros de 50 $\mathrm{nm}$ a $50 \mu \mathrm{m}$. Os poros de ar constituem $45 \%$ do volume de poros, ao passo que os microporos e os macropros compõem $20 \%$ e $10 \%$ do total, respectivamente (TADA; NAKANO, 1983).

A incorporação de ar no concreto, dada pelo ingresso de pequenas bolhas de ar em sua matriz, é um procedimento complexo, que envolve inúmeras variáveis, tais como: processo de mistura, características dos agregados, propriedades físicoquímicas do cimento, quantidade de água, aditivos, propriedades do agente de introdução de ar, dentre outros parâmetros. Pesquisas demonstram que o uso de agregados e cimento mais finos, argamassa com menor trabalhabilidade e alta temperatura do concreto são fatores que diminuem o conteúdo de ar e afetam a eficiência do processo (DU; FOLLIARD, 2005).

A porosidade do concreto celular é uma propriedade que compromete o desempenho mecânico do material, sendo a autoclavagem o método mais usual para compensar essa perda. Em contrapartida, meios de controlar a formação de poros e aprimorar a resistência mecânica do material sem a cura em autoclave foi estudada por Cabrillac et al. (2006). Corpos de prova de concreto celular não autoclavado foram analisados em relação a variações composicionais, ou seja, quantidade de água e areia, tipo de ligante e dosagem do agente expansivo. Os resultados dos 
ensaios à compressão demonstraram que uma maior quantidade de areia ou cal na composição aumenta a resistência do concreto celular, ao passo que um acréscimo na quantidade de cimento ou na dosagem do agente expansor tende a reduzir o desempenho mecânico do material.

\subsubsection{Método de Cura}

O método de cura detém grande importância na durabilidade e desenvolvimento de resistência do concreto, assim como em outras propriedades diretamente associadas ao seu desempenho - porosidade, absorção de umidade e retração. Há, portanto, diferenças determinantes na estrutura de concretos celulares não autoclavados em relação a corpos de prova sujeitos à autoclavagem, isto é, a técnica que envolve a moldagem e o processamento hidrotérmico dos materiais sob temperaturas acima de $110^{\circ}$ e pressões saturadas de vapor.

A cura de materiais cimentícios em condições normais de temperatura e pressão depende essencialmente do aglomerante e de sua capacidade de unir os agregados. A cura sob condições de alta temperatura e pressão em vapor saturado, por sua vez, implica em uma reação química entre parte dos materiais silicosos e os elementos calcários, originando uma microestrutura com produtos de reação detentores de superfície específica menor do que os obtidos por cura normal (RILEM, 1993).

O produto inicial dessa reação é o silicato de cálcio hidratado, C-S-H, com relações variáveis de $\mathrm{Ca} / \mathrm{Si}$; com o avanço do tempo de cura, o produto reage com a sílica dissolvida do quartzo, formando a tobermorita $11 \mathrm{~A}^{\circ}(5 \mathrm{CaO} \cdot 6 \mathrm{SiO} 2 \cdot 5 \mathrm{H} 2 \mathrm{O})$, isto é, o principal ligante mineral do CCA. A composição do concreto sofre mudanças durante a autoclavagem, levando ao aumento do número de microporos e ao acréscimo em sua resistência devido ao efeito de ligação da tobermorita. (MITSUDA et al., 1992).

A diferença qualitativa entre materiais submetidos a técnicas de produção diversas - concreto celular autoclavado, concreto espumoso autoclavado e concreto espumoso não autoclavado - foi estudada por Tada e Nakano (1983). Avaliou-se a estrutura porosa das amostras por meio de microscopia e a distribuição dos poros através das técnicas de adsorção isotérmica e injeção de mercúrio. Os corpos de 
prova autoclavados demonstraram divisão clara entre os poros capilares advindos da tobermorita e os poros resultantes da incorporação de ar. As amostras não autoclavadas apresentaram distribuição de poros uniforme, tendo como resultado um maior volume de poros mais finos (poros de gel), o que leva a uma tendência à formação de fissuras devido à retração por secagem.

Verificações em relação à resistência à compressão, microestrutura e análise térmica foram realizadas por Wongkeo e Chaipanich (2010) para corpos de prova autoclavados e curados ao ar livre, com adições de sílica ativa e cinzas de fundo. Acréscimos no peso, resistência à compressão e condutividade térmicas foram observados com o aumento do tempo de cura. O melhor desempenho mecânico, de $18,8 \mathrm{MPa}$, foi obtido para os corpos de prova autoclavados com $20 \%$ de cinzas e $5 \%$ de sílica ativa.

\subsubsection{Variação Composicional}

A dosagem de certas substâncias e a adição de outras na composição do concreto celular são fatores influentes em seu comportamento e desempenho final. A formação de poros em sua estrutura, por exemplo, exige a adição de um agente expansor, sendo o pó de alumínio o mais comum; outros métodos incluem agente espumante, peróxido de hidrogênio, zinco em pó ou liga de alumínio (HOLT; RAIVIO, 2005).

O efeito da concentração de alumínio nas propriedades mecânicas e na porosidade do concreto celular foi investigado por Shabbar e Nedwell (2017) em amostras com $0,0,25,0,5,0,75$ e $1 \%$ de alumínio (Al) por peso de cimento. Os corpos de prova apresentaram valores decrescentes de resistência e densidade conforme o aumento de pó de alumínio utilizado na dosagem. Atribuiu-se esse comportamento à redução da taxa de produção do gel C-S-H devido à alta reatividade do alumínio.

A granulometria do pó, por sua vez, é igualmente um aspecto influente na resistência e densidade do concreto. Kumar e Ramamurthy (2015) utilizaram amostras com classes de granulometria de C50, C75, C85 e C95, dosagem variável entre $0,25 \%$ e $0,5 \%$, e pastas com diferentes razões de água/cimento. Os resultados demonstraram que, para uma dosagem constante de pó de alumínio e razão água- 
cimento na mistura, a densidade aparente reduziu-se a partir do aumento da granulometria. Ademais, amostras de classe C50 apresentaram maior resistência.

Dentre outras possíveis formulações, os concretos celulares podem fazer uso de cinza volante ao invés de areia como filler. Um estudo comparativo feito por Narayanan e Ramamurthy (2000b) avaliou a influência da adição de ambos em corpos de prova autoclavados e curados em meio úmido. Diferenças estruturais foram observadas devido ao grau de hidratação com o tempo, cujo processo é particularmente lento no caso da cinza volante. Assim, perde-se água adsorvida associada às partículas não reagentes, resultando em menor resistência e uma tendência à retração 5 vezes maior que no uso de areia. Além disso, a autoclavagem não demonstrou a mesma eficiência em produtos com cinza volante.

Resíduos podem igualmente ser adicionados na produção de concreto celular autoclavado, tal como subprodutos industriais (HEIKAL et al., 2005; MOSTAFA, 2005). O estudo de Connan (2005) utilizou resíduos ricos em sílicaalumina, advindos de demolições de edifícios. Para misturas ricas em sílica, um maior tempo de cura, menor temperatura de autoclavagem e pouca quantidade de aditivo mostraram-se benéficos para a resistência à compressão dos corpos de prova. Holt e Ravio (2005) avaliaram a adição de resíduos de processos de gaseificação, com alta quantidade de alumínio, em amostras de CCA. A adição de resíduos em quantidades de $1 \%$ e $3 \%$ foi bem-sucedida e forneceu produtos de acordo com as especificações requeridas; quantidades de até $10 \%$ seriam possíveis, desde que houvesse melhor proporção na mistura e otimização do processo.

\subsubsection{Durabilidade}

A alta porosidade do concreto celular o sujeita à penetração de agentes externos e de degradação, os quais comprometem a sua matriz. Altos níveis de umidade podem gerar danos significativos, desde processos físicos (ciclos de gelodegelo, retração) a químicos (carbonatação, corrosão, cristalização de sais) e biológicos (formação de mofo) (SCHOCH; KREFT, 2011). Dessa forma, a avaliação do desempenho a longo prazo do material sob condições úmidas é de grande interesse para aferir a sua aplicação em construções e afins. 
Dentre os problemas de durabilidade mais comuns em concretos celulares, encontra-se a carbonatação - mecanismo de degradação no qual a estrutura de tobermorita $11 \mathrm{~A}^{\circ}$ reage com dióxido de carbono, por meio da umidade, para formar a calcita, $\mathrm{CaCO}_{3}$ (MATSUSHITA; SHIBATA; KAMADA, 1999). A carbonatação do concreto leva à degradação e redução da vida útil do material. A avaliação dos danos desse processo é feita por meio de testes acelerados e em campo, a partir de diferentes composições, concentrações de dióxido de carbono e umidade relativa.

Sauman (1972) obteve reduções particularmente significativas na resistência à compressão de amostras de CCA sujeitas a concentrações de $10 \% \mathrm{e}$ $30 \%$ de $\mathrm{CO}_{2}$, com 50, 75 e 100\% de umidade relativa. Esse comportamento está estreitamente associado à decomposição da tobermorita, assim como à natureza e ao número de áreas de contato das fases de cristais de ligação. Matsushita et al. (2004) avaliaram o mecanismo de retração por carbonatação acelerada utilizando espectroscopia. Amostras laboratoriais foram submetidas a concentrações de 0,3 e $3 \%$ de $\mathrm{CO}_{2}$. Os resultados demonstraram que para graus de carbonatação abaixo de $20 \%$, a retração por carbonatação não foi observada. Para graus entre 50 a 60\%, a retração foi significativa e atingiu $0,25 \%$. As medidas feitas em campos demonstraram resultados similares às laboratoriais.

Em geral, outro fator problemático envolve ciclos de molhagem-secagem e gelo-degelo, advindos do constante acúmulo e liberação de água, o que leva a mudanças físico-químicas no material. A resistência do CCA a ciclos de gelodegelo depende altamente do teor de umidade e de sua densidade: amostras com menos de $500 \mathrm{~kg} / \mathrm{m}^{3}$ demonstram perda significativa de resistência, ao passo que corpo de provas com 500-600 kg/m², com resistência à compressão entre $1 \mathrm{MPa}$ e $2 \mathrm{MPa}$, apresentam resistência satisfatória aos ciclos para um teor de umidade inferior a 16\% (TIKALSKY; POSPISIL; MACDONALD, 2004).

Kus et al. (2004) explicitaram um estudo sobre a influência de diferentes tipos de revestimentos na durabilidade de paredes externas de CCA expostas à umidade. Painéis de CCA, de uma estrutura pré-moldada, foram monitorados no clima de Gävle, Suécia, por 4 anos. Em geral, os revestimentos apresentaram um efeito dependente do número de camadas e condição do microclima; testes realizados com produtos hidrofóbicos mostraram-se eficientes em prover melhor desempenho. 
Inúmeras pesquisas igualmente analisaram a influência de altos níveis de umidade nas propriedades térmicas do concreto celular autoclavado (HOLM; KUENZEL, 2002; SCHOCH; KREFT, 2011). O comportamento higrotérmico de corpos de prova de CCA foi estudado por Jerman et al. (2013), no qual a condutividade térmica das amostras demonstrou ser até 6 vezes superior à condição seca com o aumento do teor de umidade. A dependência da condutividade térmica com a temperatura se mostrou menos pronunciada, havendo um aumento de até $50 \%$ em uma variação de 2 a $40^{\circ} \mathrm{C}$.

Similarmente, o desempenho do CCA em um clima altamente úmido e quente foi avaliado em uma pesquisa na Tailândia, por Ungkoon et al. (2005), onde três pequenas casas com paredes compostas por materiais diversos - concreto leve, tijolo e bloco de CCA - foram monitoradas em relação ao fluxo de calor e condutividade térmica. Os resultados demonstraram melhor adequação do CCA para isolamento térmico e prevenção de umidade em comparação com os materiais alternativos.

\subsubsection{Desempenho Mecânico}

As propriedades mecânicas do concreto celular estão associadas a uma série de elementos, desde aspectos microestruturais, como cristalinidade e porosidade, até a incorporação de reforços e aditivos. A resistência à compressão do concreto é uma propriedade altamente dependente da estrutura porosa; a quantidade de silicatos de cálcio hidratados também exerce considerável contribuição para a resistência do material (HOFF, 1972). Em geral, a resistência cresce conforme a densidade do material e decresce no caso de aumento da porosidade.

O módulo de elasticidade do concreto celular também depende da umidade e densidade; sua relação com ambas as propriedades pode ser expressa em equações empíricas obtidas por regressão linear, conforme explicitado por RILEM (1993). Geralmente o módulo de elasticidade do concreto celular apresenta valores inferiores aos módulos de concretos usual e leve, variando de 1 a 8 GPa para uma densidade de 400-1200 kg/m³ (QU; ZHAO, 2017).

A resistência à flexão, por sua vez, pode alcançar 20 a 40\% da resistência à compressão, tendendo a zero no caso de densidades muito baixas. Tal resistência 
tende a ser superior aos valores de resistência à tração, e o módulo de ruptura pode ser estimado por meio de uma relação linear com a resistência à compressão (RILEM, 1993).

Valores médios de resistência à compressão e seus respectivos módulos de elasticidade e densidade foram expressos por Narayanan e Ramamurthy (2000a), como demonstrado na Tabela 2-3.

\begin{tabular}{ccc} 
Tabela 2-3: Relação entre desempenho mecânico e densidade de CCA \\
\cline { 2 - 3 } $\begin{array}{c}\text { Densidade } \\
\left(\mathbf{k g} / \mathbf{m}^{\mathbf{3}}\right)\end{array}$ & $\begin{array}{c}\text { Resistência à } \\
\text { Compressão } \\
(\mathbf{M P a})\end{array}$ & $\begin{array}{c}\text { Módulo de } \\
\text { Elasticidade } \\
\text { Estático } \\
\left(\mathbf{k N} / \mathbf{m m}^{\mathbf{2}}\right)\end{array}$ \\
\hline 400 & $1,3-2,8$ & $0,18-1,17$ \\
500 & $2,0-4,4$ & $1,24-1,84$ \\
600 & $2,8-6,3$ & $1,76-2,64$ \\
700 & $3,9-8,5$ & $2,42-3,58$ \\
\hline \multicolumn{2}{|c|}{ Adaptado de NARAYANAN \& RAMAMURTHY (2000a) }
\end{tabular}

Relações entre a microestrutura do concreto celular autoclavado e suas propriedades mecânicas foram estabelecidas por Alexanderson (1979) em corpos de prova sob variadas condições, como proporções de mistura, aditivos e condições de autoclavagem. Resultados advindos da análise de difração de raio $\mathrm{X}$ demonstraram que os principais produtos de reação em todos os casos pertenciam ao grupo de tobermoritas. A cristalinidade de tais grupos mostrou-se influente em ambos os aspectos de retração e resistência: a primeira decresceu a partir do aumento de cristalinidade, ao passo que a resistência à compressão alcançou um valor ótimo. A resistência também aumentou com a quantidade total de silicatos de cálcio hidratados e porosidade decrescente.

A incorporação de materiais pozolânicos no cimento é frequentemente utilizada para aprimorar algumas de suas propriedades. O estudo de Wongkeo et al. (2012) avaliou o efeito da substituição parcial do cimento Portland por cinzas de fundo em quantidades de 0 a $30 \%$ por peso. Cubos de $50 \mathrm{~mm}$ de aresta foram testados à compressão e alcançaram valores de 10,9 e 11,6 MPa para a adição de 
20 e $30 \%$ de pozolana, respectivamente. Prismas de $40 \mathrm{~mm}$ x $40 \mathrm{~mm}$ x $160 \mathrm{~mm}$ foram testados à flexão e obtiveram resistência de 2,6 a 3,2 MPa. Todos os corpos de prova apresentaram acréscimos na resistência à compressão, densidade seca, resistência à flexão e condutividade térmica a partir do aumento na quantidade de cinzas de fundo devido à formação de tobermorita.

Substituições parciais ou completas de areia por cinza volante igualmente foram objeto de estudo em misturas de concreto celular. Para uma maior quantidade de cinza volante, a densidade do material tende a ser menor devido à finura e menor gravidade específica da cinza volante. Essa redução na densidade não leva a uma perda considerável de resistência em virtude de sua pozolanicidade. Para uma dada densidade, um maior teor de cinza volante resulta em melhor resistência à compressão (NARAYANAN; RAMAMURTHY, 2000a). Hauser (1999) estudou o uso de cinza volante, advinda da indústria de celulose, como substituta para o cal e o sulfato nas misturas, mas os resultados não foram satisfatórios.

Além disso, para aprimorar as propriedades mecânicas do concreto celular, é possível adicionar fibras em sua estrutura, de forma que o produto final alcance melhor ductilidade e maior resistência à tração e à flexão. Laukaitis et al. (2009) investigaram a influência de aditivos fibrosos, como carbono, polipropileno e basalto, nas propriedades de mistura do concreto celular autoclavado. As fibras, em volume crescente de $0,1 \%$ a $0,4 \%$, mostraram-se influentes na resistência plástica, que aumentou, e na fluidez da mistura, que diminuiu. A quantidade ótima de 0,3\% forneceu um aumento na resistência à compressão e à flexão das amostras de CCA para todas as fibras analisadas. O melhor desempenho coube às fibras de carbono, conforme também demonstrou um estudo similar (PEHLIVANLI et al., 2016).

O desempenho de corpos de prova de concreto celular reforçado com fibras curtas de polipropileno foi comparado a amostras de concreto celular autoclavado sem reforço por Dey et al. (2014). Ensaios de impacto foram realizados sob diferentes alturas $(25,75$ e $150 \mathrm{~mm})$ na configuração de flexão a três pontos. As amostras reforçadas com fibras demonstraram maior ductilidade, com até 3 vezes a tenacidade à flexão apresentada pelos corpos de prova de CCA.

Um estudo similar conduzido por Bonakdar et al. (2013) avaliou o desempenho mecânico do mesmo tipo de material, com frações volumétricas de $0,18 \%, 0,27 \%$ e $0,36 \%$ de fibras de polipropileno. Os corpos de prova reforçados 
com a maior quantidade de fibras apresentaram $3 \mathrm{MPa}$ de resistência à compressão, 0,56 $\mathrm{MPa}$ de resistência à flexão, tenacidade superior a $25 \mathrm{Nm}$ e condutividade térmica de $0,15 \mathrm{~W} / \mathrm{Km}$. A resistência à compressão mostrou-se inferior devido à ausência de autoclavagem na produção dos corpos de prova reforçados, uma vez que o processo afetaria as fibras. A tenacidade apresentada pelas amostras reforçadas, por outro lado, foi 83 vezes mais que a tenacidade de amostras de CCA, comprovando a eficácia do controle de impactos e absorção de energia resultante da adição de fibras.

\subsection{Painéis Sanduíche}

A estrutura do painel sanduíche baseia-se na união de três elementos principais: duas lâminas exteriores finas, de material resistente, e um elemento de núcleo leve com rigidez reduzida. Os painéis sanduíche possuem inúmeras variações estruturais, seja em termos do tipo de material, espessura ou densidade. Usualmente as lâminas são idênticas em propriedades e dimensões e, independentemente da configuração do painel como um todo, as mesmas resistem aos esforços de flexão, enquanto o núcleo suporta os esforços de cisalhamento, atuando como apoio para as lâminas (VINSON, 1999).

Os painéis são materiais multifuncionais, com elevada rigidez, isolamento térmico e eficiência de fabricação (ARBAOUI et al., 2015). Ademais, o uso de painéis sanduíche leva a um aprimoramento da rigidez à flexão sem a adição de um peso substancial à estrutura, além de melhorar sua capacidade de absorção de energia (XIONG et al., 2018).

O conjunto dessas propriedades faz do painel sanduíche uma escolha desejável para a aplicação industrial, sendo particularmente utilizado em estruturas navais, aeroespaciais e automotivas, as quais demandam materiais com maior capacidade de carga e resistência ao impacto (SCHAEDLER; CARTER, 2016; THILL et al., 2010). Painéis sanduíche pré-moldados de concreto podem ser eficientemente aplicados em paredes externas, com função estrutural e de isolamento térmico, em ambientes residenciais ou comerciais (EINEA et al., 1991).

Em geral, a eficiência de tal combinação de diferentes elementos e suas respectivas propriedades depende essencialmente do funcionamento do painel 
como um material estrutural único - aspecto associado ao seu método de produção, escolha de materiais adequados, aderência lâminas-núcleo e transferência de esforços entre os elementos. Devido aos fatores influentes em seu desempenho, o projeto estrutural de painéis sanduíche é particularmente complexo, pois exige o conhecimento prévio do comportamento mecânico das lâminas e do núcleo, tal como de seus mecanismos de ruptura (ARBAOUI et al., 2015).

\subsubsection{Propriedades Gerais}

A constante demanda por estruturas sanduíche ao longo dos anos deve-se não somente ao desenvolvimento e aplicação de novos materiais, mas às suas inúmeras vantagens, dentre as quais destacam-se o considerável desempenho mecânico e a alta relação de rigidez à flexão por peso - o que permite que a estrutura sofra menores deformações e forneça um peso estrutural menor do que outras construções para uma mesma condição de carregamento (VINSON, 2001).

A variedade de combinações de materiais de lâminas e núcleos implica em uma série de configurações possíveis para construções sanduíche. De acordo com Davies (2008), as lâminas, de alta resistência, são usualmente fabricadas com alumínio, madeira, concreto. O núcleo pode ser feito por material plástico sólido, espuma rígida (poliuretano, poliestireno, espuma fenólica), estruturas honeycomb de metal ou papel, entre outras. A Figura 2-5 demonstra alguns tipos de núcleo mais frequentemente utilizados. A aderência entre as partes também exerce papel fundamental no desempenho da estrutura.

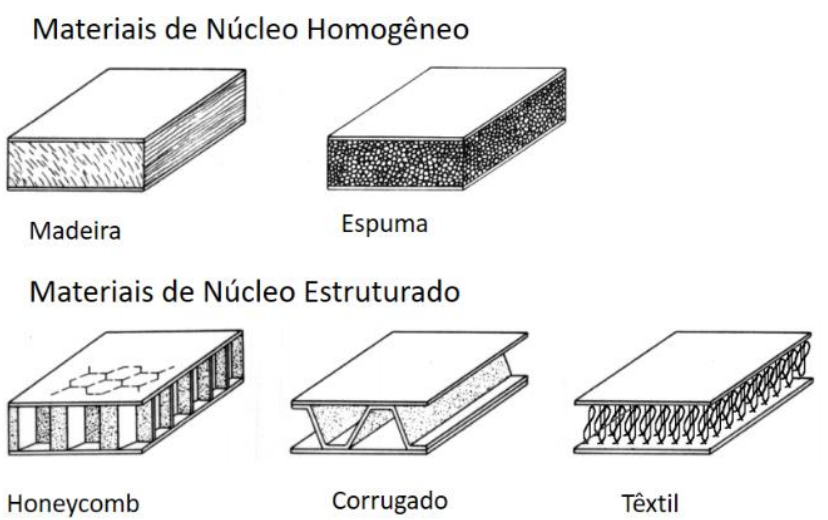

Figura 2-5: Tipos comuns de núcleo. Adaptado de PFLUG et al. (2002) 


\section{- Lâminas}

As lâminas de um painel sanduíche são usualmente finas, resistentes e com um módulo de elasticidade relativamente alto (DAVIES, 2008). Em geral, as lâminas detêm um desempenho mecânico superior ao apresentado pelo núcleo, apesar de serem menos espessas. A disparidade entre ambos, no caso de estruturas sanduíche comumente utilizadas em construção, é de uma razão núcleo/lâmina de 1 a 50 em espessura em contraste com uma razão de 50 a 1000 em termos de módulo (MOUSA; UDDIN, 2010).

As propriedades de interesse primário de uma lâmina envolvem alta rigidez à flexão, alta resistência à tração e à compressão, bem como resistência ao impacto. A escolha do material adequado para as lâminas também deve se ater a propriedades de tenacidade, fratura, durabilidade, suscetibilidade à umidade, entre outras características que podem afetar ou limitar seu uso (MARSHALL, 2013).

\section{- Núcleo}

O núcleo deve satisfazer três funções principais para o pleno funcionamento da estrutura sanduíche: ser rígido na direção perpendicular às lâminas de maneira a distancia-las corretamente; ser suficientemente rígido no cisalhamento para que as lâminas não deslizem em caso de flexão do painel; ser rígido de forma a manter as lâminas em posição plana (ALLEN, 1969). Caso essas condições não sejam satisfeitas, há riscos da estrutura se comportar como elementos independentes ou sofrer flambagem local.

Para que um material seja considerado adequado para a aplicação no núcleo de uma construção sanduíche, ele deve possuir uma série de propriedades: em termos mecânicos, as resistências à tração, à compressão e ao cisalhamento são as caraterísticas mais relevantes; em termos físicos, isolamento térmico, resistência à absorção de umidade e isolamento acústico são propriedades desejáveis (DAVIES, 2008). Os núcleos geralmente resumem-se a: espuma ou material sólido, honeycomb, web e corrugado. 


\section{- Aderência}

A camada de aderência entre os elementos de um painel é altamente influente em seu comportamento. O material adesivo que une o núcleo às lâminas permite que haja uma ligação forte entre os componentes e que os mesmos possam atuar como uma unidade (MOUSA; UDDIN, 2009).

De acordo com Davies (2008), há uma grande variedade de tipos de material adesivo, os quais podem ser escolhidos com base nos materiais de interface, na temperatura de serviço ou ainda no quesito de resistência ao fogo. Tais materiais são normalmente líquidos para a sua melhor incorporação na manufatura dos painéis. Adesivos de poliuretano são os mais utilizados para unir as lâminas ao núcleo. Dentre as propriedades relevantes para o material adesivo, encontra-se a sua tenacidade, a qual influencia na resistência necessária para separar as lâminas do núcleo sob condições estáticas ou dinâmicas - o que leva a uma melhor durabilidade e maior vida útil para o painel (MARSHALL, 2013).

\subsubsection{Princípios Teóricos}

\subsubsection{Teoria de Vigas}

Um painel sanduíche consiste basicamente em duas lâminas, de espessura t, conectadas a um material de menor densidade, com espessura c, como ilustrado na Figura 2-6. As lâminas são finas, resistentes e rígidas, ao passo que o núcleo é mais leve e espesso.

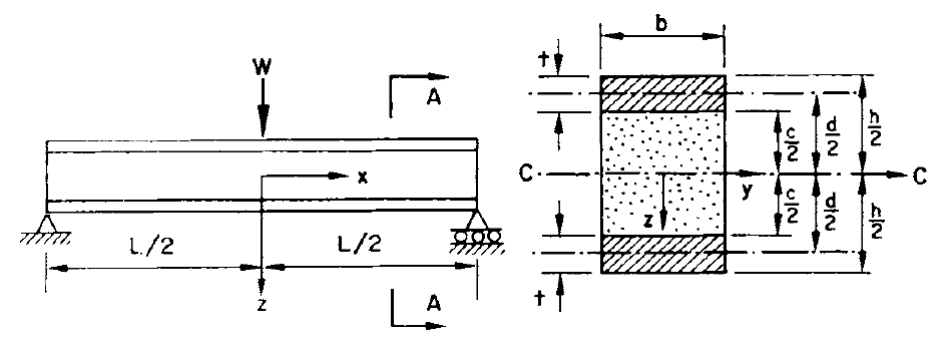

Figura 2-6: Dimensões de uma viga sanduíche e de sua seção transversal, medidas pelo eixo central da estrutura. Adaptado de ALLEN (1969)

Em termos gerais, o comportamento do painel sanduíche é equiparável a uma viga I, uma vez que as lâminas, de maneira análoga às mesas, suportam as 
tensões de tração e compressão, ao passo que o núcleo, tal como a alma da viga, resiste às tensões de cisalhamento (ZENKERT, 1995). Ademais, o núcleo separa ambas as lâminas, distanciando-as da linha neutra - e uma vez que o momento de inércia é proporcional ao quadrado da distância do elemento em relação ao eixo central, tem-se que estruturas sanduíche detêm elevada rigidez à flexão. Consequentemente, núcleos mais espessos tendem a aumentar a rigidez dos painéis sem que o peso da estrutura aumente consideravelmente.

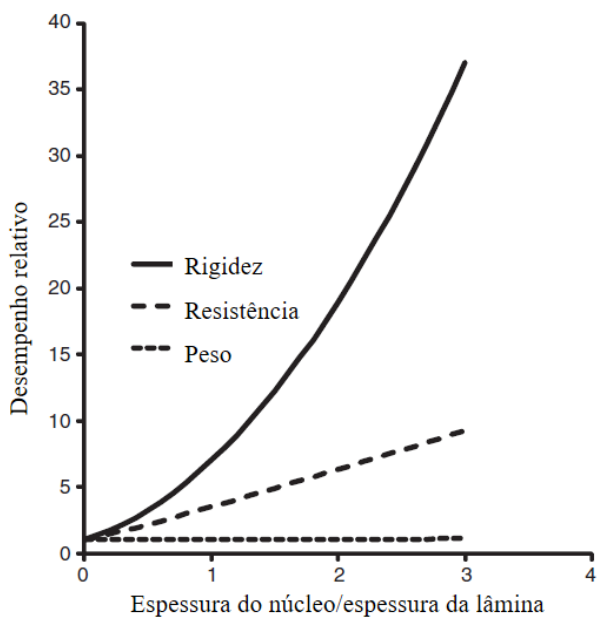

Figura 2-7: Benefício mecânico dos painéis sanduíche a partir do aumento da razão entre a espessura do núcleo e a espessura das lâminas, de 0 a 3 vezes maior. Adaptado de VIZZINI (2010)

A teoria das vigas pode ser utilizada para explicar o comportamento mecânico de vigas sanduíche, aproximando-se as tensões e deflexões dessa estrutura às equações clássicas de flexão, conforme explicitado por Allen (1969). A comparação exige hipóteses simplificadoras: as lâminas e núcleo são considerados materiais isotrópicos; as lâminas detêm rigidez superior ao núcleo; as seções transversais permanecem planas após flexão; há uma forte ligação entre os três elementos, de forma que não há deslizamento relativo.

Para uma viga comum, o produto do módulo de elasticidade e o momento de inércia, EI, representa a rigidez à flexão. De forma análoga, a rigidez de uma viga sanduíche pode ser caracterizada por $\mathrm{D}$, equação que representa a soma das rigidezes de flexão de cada elemento da estrutura, lâminas e núcleo, medidas a partir do eixo centroidal:

$$
D=E_{f} \frac{b t^{3}}{6}+E_{f} \frac{b t d^{2}}{2}+E_{c} \frac{b c^{3}}{12}
$$


Onde:

$\mathrm{D}$ = rigidez à flexão da viga;

$\mathrm{E}_{\mathrm{f}}=$ módulo de elasticidade das lâminas;

$\mathrm{E}_{\mathrm{c}}=$ módulo de elasticidade do núcleo;

$\mathrm{b}=$ largura da viga;

$\mathrm{t}=$ espessura de cada lâmina;

c = espessura do núcleo;

d = distância entre os centróides da lâmina;

Os dois primeiros termos da equação representam a rigidez das lâminas, sendo o primeiro referente à flexão local das lâminas quanto ao próprio eixo centroidal e o segundo associado à rigidez em relação à linha neutra. $\mathrm{O}$ terceiro termo da equação refere-se à rigidez do núcleo. Usualmente, o segundo termo é mais representativo da rigidez das lâminas, de forma que o primeiro termo representa menos que $1 \%$ do segundo quando:

$$
\frac{d}{t}>5,77
$$

Onde d pode ser definido como $d=\frac{h+c}{2}$, sendo h a altura total da viga. Painéis com lâminas finas geralmente satisfazem essa condição, tornando o primeiro termo da equação desprezível. Adicionalmente, o terceiro termo pode ser igualmente desconsiderado se a seguinte condição for satisfeita:

$$
6 \frac{E_{f}}{E_{c}} \frac{t}{c}\left(\frac{d}{c}\right)^{2}>100
$$

Para que esse termo seja inferior a $1 \%$, a razão entre os módulos de elasticidade das lâminas e do núcleo, $E_{f} / E_{c}$, deve ser elevada, o que não se pode garantir em todos os casos. Dessa forma, se as condições (2-2) e (2-3) forem válidas, a rigidez à flexão pode ser dada pela fórmula: 


$$
D=E_{f} \frac{b t d^{2}}{2}
$$

A distribuição das tensões normais nas lâminas e no núcleo do painel sanduíche pode ser igualmente definida por uma adaptação da teoria de flexão, levando-se em conta os diferentes elementos da seção transversal. Tem-se que a tensão de flexão em um ponto localizado a uma distância $z$ do eixo central é dada pelo produto do módulo de elasticidade pela deformação, onde essa última é definida como $\varepsilon=M z / D$. As maiores tensões nas lâminas e no núcleo ocorrem em suas extremidades, ou seja, quando $\mathrm{z}= \pm h / 2$ e $\mathrm{z}= \pm c / 2$, respectivamente:

$$
\left(\sigma_{f}\right)_{\max }= \pm \frac{M E_{f}}{D} \frac{h}{2} ; \quad\left(\sigma_{c}\right)_{\max }= \pm \frac{M E_{c}}{D} \frac{c}{2}
$$

Onde:

$$
\begin{aligned}
& \sigma_{\mathrm{f}}=\text { tensão nas lâminas; } \\
& \sigma_{\mathrm{c}}=\text { tensão no núcleo; } \\
& \mathrm{M}=\text { momento fletor; } \\
& \mathrm{h}=\text { espessura da viga; }
\end{aligned}
$$
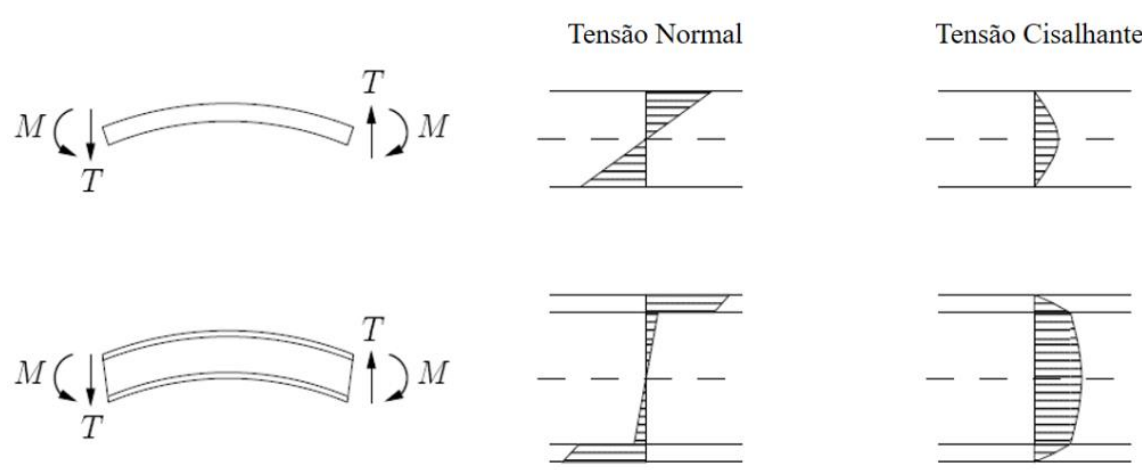

Figura 2-8: Distribuição de tensões sob flexão: acima, comportamento de uma única lâmina; abaixo, diagrama estimado para painéis sanduíche. Adaptado de WENNHAGE (2001)

Equações relativas aos esforços cisalhantes também podem ser deduzidas da teoria clássica, de acordo com Allen (1969). A tensão cisalhante em uma viga sanduíche é dada pela relação abaixo, considerando-se o produto do momento 
estático pelo módulo de elasticidade dos diferentes componentes da viga, isto é, lâminas e núcleo:

$$
\tau=\frac{V}{D b} \sum(S E)
$$

Onde:

$\tau=$ tensão cisalhante;

$\mathrm{V}=$ força de corte;

$\mathrm{D}=$ rigidez à flexão;

$\mathrm{S}=$ momento estático ou primeiro momento de área do elemento;

$\mathrm{E}=$ módulo de elasticidade;

Para uma distância z do centroide, substituindo-se o produto SE, a tensão cisalhante no núcleo é dada por:

$$
\tau=\frac{V}{D}\left\{E_{f} \frac{t d}{2}+\frac{E_{c}}{2}\left(\frac{c^{2}}{4}-z^{2}\right)\right\}
$$

Tal equação representa a relação real de distribuição da tensão cisalhante na viga sanduíche. Contudo, algumas simplificações podem ser realizadas se certas condições forem satisfeitas. Se o núcleo não contribuir para a rigidez à flexão da viga, pode-se assumir que a tensão de cisalhamento é constante ao longo da espessura do núcleo. Para que essa hipótese seja válida, tem-se que:

$$
4 \frac{E_{f}}{E_{c}} \frac{t}{c} \frac{d}{c}>100
$$

Tal condição é similar à (Eq. 2-3). Se ambas as condições forem satisfeitas, pode-se assumir que o módulo de elasticidade do núcleo é nulo e a equação pode ser descrita por:

$$
\tau=\frac{V}{D}\left(E_{f} \frac{t d}{2}\right)
$$


Para o caso mais simples, em que o primeiro e terceiro termos da equação de rigidez à flexão podem ser eliminados, ou seja, quando as condições das equações (2-2) e (2-3) são simultaneamente satisfeitas, bem como a (2-8), tem-se que a tensão cisalhante pode ser dada por:

$$
\tau=\frac{V}{b d}
$$

A distribuição de tensões para cada situação está indicada na Figura 2-9. As simplificações dependem das propriedades e dimensões dos materiais componentes do painel sanduíche analisado.

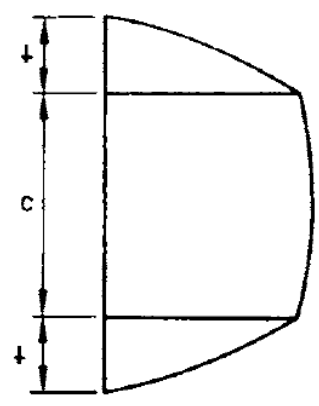

a)

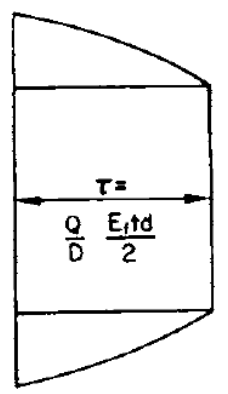

b)

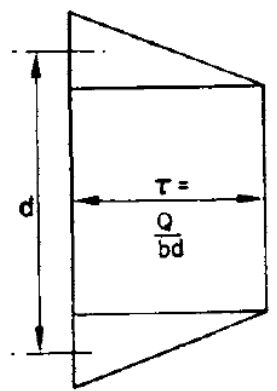

c)

Figura 2-9: Distribuição das tensões cisalhantes na viga sanduíche: a) verdadeira distribuição de tensões, representada pela equação (2-7); b) para um núcleo pouco resistente (condições 2-3 e 2-8 satisfeitas); c) para um núcleo pouco resistente e desconsideração da flexão das lâminas em seu próprio eixo centroidal (condições 2-2, 2-3 e 2-8 satisfeitas). Adaptado de ALLEN (1969)

\subsubsection{Modos de Ruptura}

O desempenho estrutural de painéis sanduíche não depende exclusivamente de seus materiais isolados ou de sua aderência, mas igualmente da qualidade da estrutura, das condições de carregamento e de seus respectivos mecanismos de ruptura (DANIEL; ABOT, 2000).

Painéis sanduíche submetidos a esforços de flexão e cisalhamento podem chegar à ruptura através de uma variedade de formas e, após o início do processo, a interação de modos de ruptura pode ocorrer e levar à falha da estrutura a partir de um mecanismo adicional (DANIEL; GDOUTOS, 2009). De acordo com Gibson e 
Ashby (1997), os modos de ruptura mais comuns para uma viga ou painel sanduíche são:

i. $\quad$ ruptura por tração das lâminas;

ii. ruptura por enrugamento (wrinkling) das lâminas;

iii. ruptura por cisalhamento do núcleo;

iv. ruptura por descolamento da interface entre lâminas-núcleo (falha da aderência);

Os modos de ruptura encontram-se representados, em ordem, na Figura $2-10$.

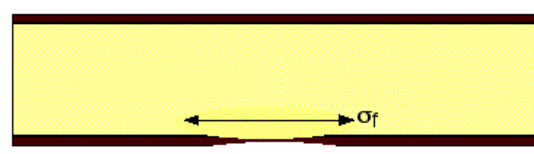

i)

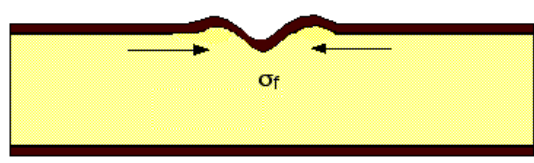

ii)

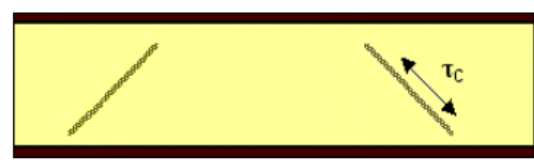

iii)

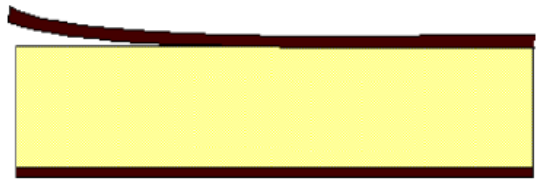

iv)

Figura 2-10: Representação dos modos de ruptura dos painéis sanduíche e dos esforços atuantes, quando aplicável. O modo i representa a ruptura por tração das lâminas; o modo ii demonstra o enrugamento das lâminas; o modo iii indica a ruptura por fissuras de cisalhamento no núcleo; o modo iv representa o descolamento entre lâmina e núcleo. Adaptado de PILLING (2019)

A ruptura das lâminas ocorre quando o material das mesmas não consegue suportar as tensões de tração originárias dos momentos de flexão. O enrugamento das faces, por sua vez, ocorre devido a tensões de compressão (DAVIES, 2008). O descolamento ou delaminação entre lâminas e núcleo ocorre quando a aderência do painel não consegue suportar as tensões de cisalhamento atuantes na estrutura.

A ruptura do núcleo por cisalhamento e a indentação (esmagamento das lâminas e núcleo na região dos apoios) ocorrem quando a tensão última do núcleo é alcançada e o mesmo chega à ruptura antes das lâminas (BRUFFEY; SHIU, 2016). Tal processo de esmagamento dos elementos nos apoios pode ser suprimido ao distribuir o carregamento em uma área equivalente à da seção transversal (GIBSON; ASHBY, 1997). 


\subsubsection{Comportamento Mecânico de Painéis Sanduíche Cimentícios}

As propriedades mecânicas dos painéis sanduíche são dependentes do comportamento individual de seus elementos, assim como de seu desempenho conjunto, como um material essencialmente compósito. Em geral, as lâminas do painel, sujeitas a esforços de tração ou compressão, são consideravelmente responsáveis pela resistência à flexão e rigidez da estrutura sanduíche, ao passo que o núcleo está associado aos esforços de cisalhamento (MANALO; ARAVINTHAN; KARUNASENA, 2013). A espessura do núcleo influencia na rigidez à flexão, ao passo que sua resistência ao cisalhamento é determinante em condições de carga que introduzam momentos de flexão e forças de cisalhamento fora do plano (FRAZÃO et al., 2018).

A escolha dos constituintes de um painel é, portanto, essencial em seu desempenho, e a pesquisa por novos materiais tem sido mais investigada, notandose a substituição crescente de lâminas metálicas por compósitos laminares, devido à sua relação satisfatória de resistência por peso (SHENHAR; FROSTIG; ALTUS, 1996). Dessa forma, o concreto reforçado com fibras, seja como reforço discreto ou contínuo, tornou-se aplicação comum, juntamente com um núcleo de isolamento térmico e conectores de cisalhamento entre os elementos, quando necessário. $\mathrm{O}$ comportamento mecânico de tais painéis foi abordado por uma série de autores, particularmente em relação ao seu desempenho sob flexão (GARA et al., 2012; WILLIAMS PORTAL et al., 2017).

Colombo et al. (2015) avaliaram corpos de prova com $550 \mathrm{~mm}$ x $150 \mathrm{~mm}$ e $1200 \mathrm{~mm}$ x $300 \mathrm{~mm}$ de concreto reforçado com tecido de fibra de vidro-AR e núcleo de espuma de poliestireno expandido por meio de ensaios de flexão a quatro pontos. Os menores e maiores corpos de prova atingiram força máxima de 9,19 kN e 16,38 $\mathrm{kN}$, respectivamente. Corpos de prova de ambas as geometrias apresentaram comportamento dúctil e múltipla fissuração dos compósitos. Similarmente, Hegger e Horstmann (2010) desenvolveram painéis sanduíche pré-fabricados com finas lâminas de concreto reforçado com tecido de fibra de vidro e núcleo de espuma de poliuretano para a aplicação em fachadas e construções modulares. Em geral, a estrutura demonstrou desempenho mecânico adequado para ser utilizado em 
construções, apresentando capacidade de carga satisfatória em ensaios de flexão a quatro pontos com vãos de 1,90 e 4,90 m.

Além disso, materiais naturais podem ser aplicados em painéis sanduíche, como demonstra o estudo de Frazão et al.(2018), onde compósitos cimentícios reforçados com fibras de sisal, curtas e longas, foram utilizados como lâminas dos corpos de prova. Os compósitos, com ambos os tipos de reforço, foram moldados em um núcleo de concreto leve reforçado com fibras de polipropileno. O comportamento dos painéis de $700 \mathrm{~mm}$ x $200 \mathrm{~mm}$ x $90 \mathrm{~mm}$ sob flexão a quatro pontos e seus modos de ruptura foram discutidos. Os painéis com fibras curtas atingiram uma força máxima média de $7 \mathrm{kN}$ e uma deflexão equivalente de $2 \mathrm{~mm}$, aproximadamente. Os corpos de provas com fibras longas alcançaram $18 \mathrm{kN}$ e 11 $\mathrm{mm}$, respectivamente. Os resultados indicaram que o uso de fibras longas levou a uma melhor resistência à flexão e um comportamento de múltipla fissuração.

A vida útil de painéis sanduíche, tal como a durabilidade associada à combinação dos materiais constituintes, foi abordada em algumas pesquisas. $\mathrm{O}$ projeto de painéis sanduíche com compósitos cimentícios reforçados com fibras de vidro foi avaliado por Cwpers et al. (2007), considerando-se o efeito da durabilidade na estrutura em estado de limite último. Três modelos de durabilidade foram utilizados para prever a evolução de resistência dos compósitos aplicados nos painéis, calibrando-os de acordo com dados experimentais da literatura sob condições de envelhecimento acelerado. Misturas cimentícias alternativas também foram desenvolvidas para o aprimoramento da durabilidade: Cuypers e Wastiels (2011) utilizaram lâminas com reforço de vidro-E e matriz de IPC (inorganic phosphate cement), de natureza não alcalina, em painéis com núcleo de espuma de poliestireno para uma comparação entre a análise preditiva e os resultados experimentais.

Em termos de núcleo, usualmente os painéis sanduíche utilizam estruturas do tipo honeycomb ou espuma de poliestireno. Há, contudo, outros materiais que atuam como bons isoladores térmicos, como o concreto celular autoclavado. Elkashef e Abdelmooty (2015) investigaram as diferenças de desempenho entre o CCA e a espuma rígida a partir de ensaios de flexão, com diferentes conectores de cisalhamento, em painéis com lâminas de concreto. Em geral, o uso de CCA obteve melhores resultados em termos de rigidez e modo de ruptura dos corpos de prova 
testados. Apesar de não ter aumentado a resistência máxima dos painéis, os corpos de provas com CCA demonstraram transferência de esforços adequada entre os elementos (comportamento de fully composite).

Outro estudo comparativo com diferentes tipos de núcleo foi realizado por Dey et al.(2015), envolvendo concreto celular autoclavado (CCA) e concreto celular polimérico reforçado com fibras de polipropileno. Ensaios de flexão a três pontos sob carregamento estático e dinâmico foram realizados em painéis sanduíche com lâminas de concreto reforçado com fibras (CRF) de vidro-AR. Para o ensaio estático de flexão, painéis CRF-CCA com dimensões de $50 \mathrm{~mm}$ x $50 \mathrm{~mm}$ x $250 \mathrm{~mm}$ alcançaram uma resistência à flexão de 2,4 MPa, rigidez inicial de 1780 $\mathrm{N} / \mathrm{mm}$ e deflexão de 1,34 mm no ponto de carga máxima. Corpos de prova de concreto celular polimérico, com as mesmas dimensões, obtiveram 3,7 MPa, 1980 $\mathrm{N} / \mathrm{mm}$ e 3,89 mm, respectivamente. Em geral, as lâminas reforçadas com fibras aprimoraram consideravelmente a rigidez, capacidade de carga e de absorção de energia de todos os corpos de prova. 


\section{Propriedades e Caracterização dos Materiais}

\subsection{Introdução}

O painel sanduíche é uma estrutura composta por três camadas: duas lâminas resistentes interpostas por um núcleo de baixa densidade. Para o desenvolvimento do conjunto, torna-se necessária a análise individualizada de seus materiais componentes. No caso do presente trabalho, isso implica na caracterização do compósito cimentício com reforço unidirecional de fibras de curauá, elemento das camadas superior e inferior, e do concreto celular autoclavado, que compõe o núcleo.

Uma vez que o desempenho do compósito reforçado com fibras é particularmente importante no estágio de pós-fissuração, a partir da transferência de tensões fibra-matriz, é necessário verificar se a matriz detém uma interação apropriada com o reforço. Adicionalmente, as fibras naturais, em razão de sua alta permeabilidade, são suscetíveis a problemas de durabilidade que afetam sua relação com a matriz, sobretudo variações de volume por umidade.

O concreto celular autoclavado, em contrapartida, é um material isotrópico, homogêneo e pouco denso. As suas propriedades são altamente dependentes de sua densidade, umidade e porosidade, de modo que a compreensão de seu desempenho mecânico depende da análise desses fatores.

De maneira a garantir melhores durabilidade e desempenho ao compósito, desenvolveu-se uma matriz com baixo teor de hidróxido de cálcio, substituindo uma parcela do cimento por materiais pozolânicos. A consistência ideal da matriz também foi determinada para que essa melhor adentrasse no tecido de reforço. As fibras de curauá, por sua vez, foram analisadas em relação à sua morfologia e resistência, enquanto o concreto celular autoclavado foi avaliado no que se refere à densidade, teor de umidade e comportamento mecânico.

O organograma representado na Figura 3-1 explicita os ensaios utilizados para a caracterização das propriedades dos materiais, assim como para a avaliação 
de seu desempenho individual. Os compósitos e os painéis sanduíche foram avaliados em capítulos separados (capítulos 3 e 4, respectivamente) devido à profundidade do tema.

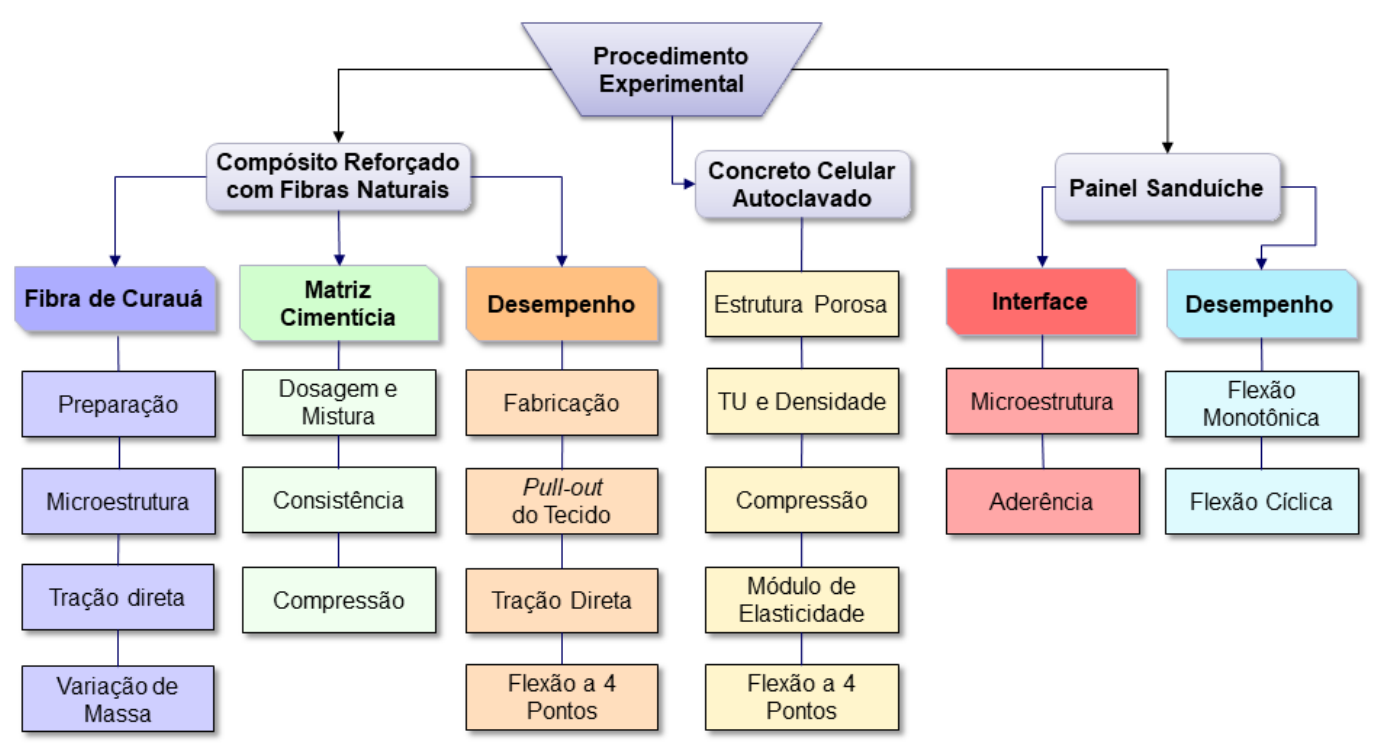

Figura 3-1: Organograma do procedimento experimental geral do trabalho

\subsection{Matriz Cimentícia}

\subsubsection{Materiais Constituintes}

Para a composição e desenvolvimento da matriz, os seguintes materiais foram empregados: cimento CPV-ARI de alta resistência inicial, fabricado por Holcim; cinza volante, advinda da empresa Pozofly; metacaulim, distribuído por Metacaulim do Brasil Industria e Comercio Ltda; areia de rio passante na peneira de $1,4 \mathrm{~mm}$ de abertura e retida na de $0,15 \mathrm{~mm}$.

De maneira a garantir dispersão e trabalhabilidade adequadas à mistura, utilizou-se 2,5\% de superplastificante Plastol 4100, fabricado pela Viapol. O aditivo possui teor de sólidos de $40 \%$ e massa específica aproximada de $1,1 \mathrm{~g} / \mathrm{cm}^{3}$, segundo o fabricante. O cimento CPV-ARI detém $95-100 \%$ de sua massa em forma de clínquer e sulfatos de cálcio, tal como materiais carbonáticos em 0-5\% de massa, de acordo com a NBR 5733 (1991).

A cinza volante adquirida é de classe $\mathrm{C}$ e possui mais de $70 \%$ de sua composição em $\mathrm{SiO}_{2}, \mathrm{Al}_{2} \mathrm{O}_{3}$ e $\mathrm{Fe}_{2} \mathrm{O}_{3}$, sendo menos de $5 \%$ composto por $\mathrm{SO}_{3}$ - 
propriedades em conformidade com os requisitos químicos prescritos pela NBR 12653 (2012). O metacaulim utilizado, por sua vez, detém massa específica de 2,60 $\mathrm{g} / \mathrm{cm}^{3}$, com 50-65\% de sua composição em $\mathrm{SiO}_{2}, 27-44,5 \%$ de $\mathrm{Al}_{2} \mathrm{O}_{3}$ e menos de $5 \%$ em $\mathrm{Fe}_{2} \mathrm{O}_{3}$, conforme indicado pelo fabricante.

A composição granulométrica da areia, agregado miúdo da matriz, foi obtida por meio de um agitador mecânico de peneiras Mesh, através de malhas com abertura de $0,15 \mathrm{~mm}, 0,30 \mathrm{~mm}, 0,60 \mathrm{~mm}, 1,18 \mathrm{~mm}$ e $1,4 \mathrm{~mm}$. O tamanho e distribuição das partículas de uma amostra de $1000 \mathrm{~g}$ é demonstrada por meio da curva granulométrica indicada na Figura 3-2.

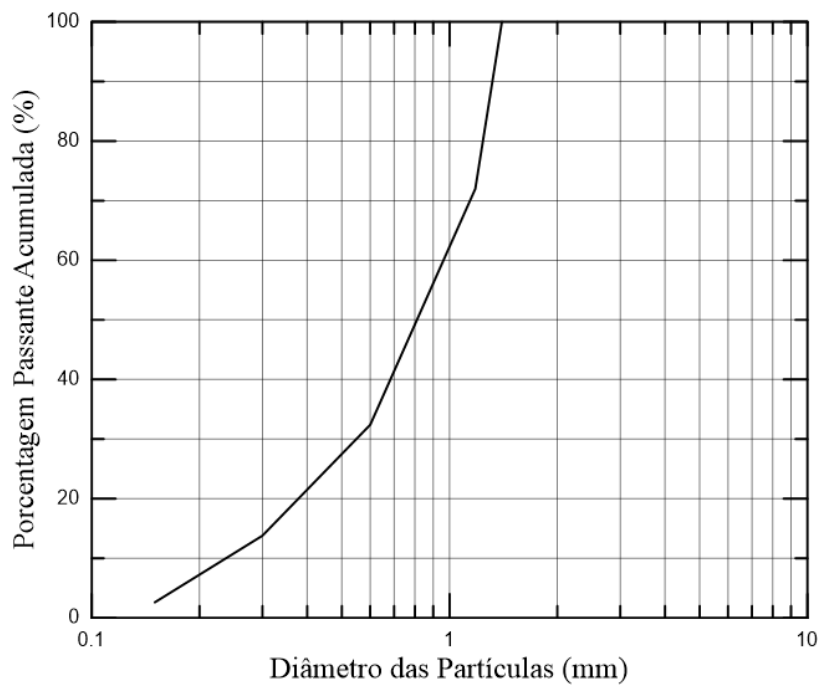

Figura 3-2: Granulometria do agregado miúdo

\subsubsection{Processo de Dosagem e Mistura}

A dosagem da matriz, cujo traço de 1:1:0,4 (areia:materiais cimentícios:água) foi adotado em concordância com o de Fidelis (2014), compreende uma substituição parcial do cimento por $40 \%$ de massa em metacaulim e $10 \%$ em cinza volante, de forma a reduzir seu teor de hidróxido de cálcio. Em relação à consistência da matriz, o teor de 2,5\% de superplastificante mostrou-se adequado para a fluidez desejada (conforme explicitado na seção 3.2.3).

A preparação e homogeneização da argamassa foi realizada em uma argamassadeira planetária de 5 litros, de acordo com o seguinte procedimento: mistura da areia com aproximadamente metade da quantidade de água prevista, por 1 minuto, em baixa velocidade (136 rpm); adição dos materiais cimentícios e da 
água restante por meio minuto, em mesma velocidade; adição gradual do superplastificante e homogeneização da mistura por 4 minutos em velocidade superior (281 rpm). A Figura 3-3 demonstra a execução do processo e suas respectivas etapas:

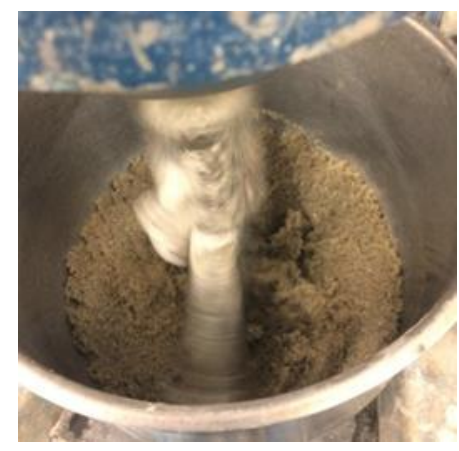

a)

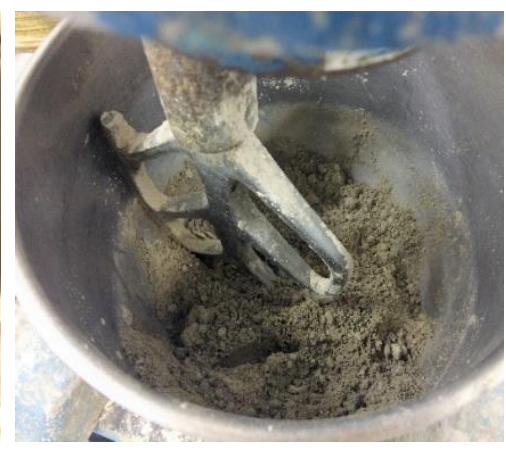

b)

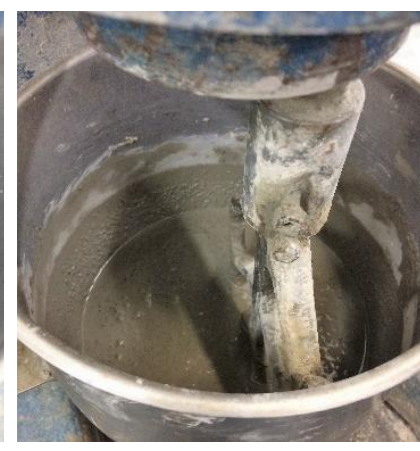

c)

Figura 3-3: Processo de mistura: a) mistura composta por areia e água; b) adição dos materiais cimentícios e água restante; c) argamassa após a adição do superplastificante e mistura em alta velocidade

\subsubsection{Propriedades da Matriz em Estado Fresco}

De modo a avaliar a reologia da mistura, é necessário obter informações relativas à consistência da matriz. Para esse fim, utilizou-se a norma ASTM C230 (2014) para a execução do ensaio de espalhamento, adaptado para um molde de dimensões $12,5 \mathrm{~cm}$ x 8,0 cm x 6,5 cm (base maior x base menor x altura).

O procedimento baseou-se na disposição da argamassa no interior do molde tronco-cônico, estabelecido no centro de uma mesa horizontal lisa. Uma vez que a argamassa atinja a borda do molde, a superfície é regularizada por meio de uma régua ou espátula, e o cone retirado de maneira que a mistura seja liberada e espalhada livremente pela mesa.

O índice final de consistência é definido como a média aritmética entre os diâmetros ortogonais, sendo os ensaios repetidos até que os valores consecutivos não ultrapassem $5 \mathrm{~mm}$ de diferença entre si. As imagens da Figura 3-4 demonstram a execução do ensaio. O ensaio de consistência foi aplicado para diferentes quantidades de superplastificante com o intuito de definir o teor ótimo do aditivo. Os resultados para variações de 1,5\%,2\%,2,5\% e $3 \%$ de superplastificante encontram-se na Tabela 3-1. 


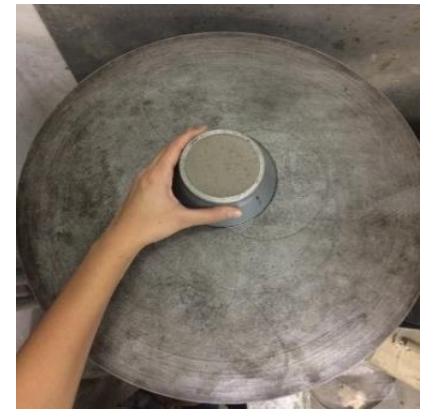

a)

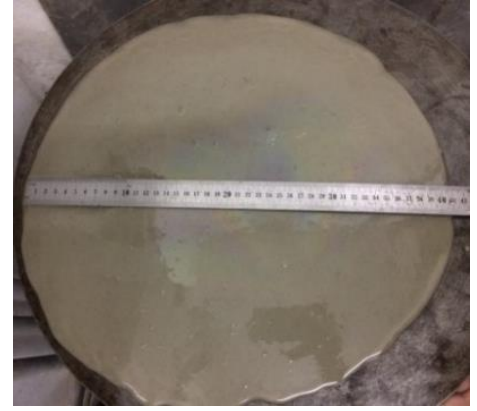

b)

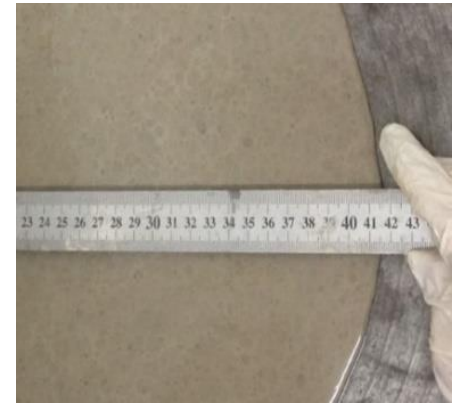

c)

Figura 3-4: Teste de consistência: a) argamassa inserida no molde tronco-cônico; b) medida de um dos diâmetros; c) medida do diâmetro consecutivo, em detalhe

Tabela 3-1: Teor variável de superplastificante e seu respectivo espalhamento

\begin{tabular}{cc}
\hline $\begin{array}{c}\text { Teor de SP } \\
(\%)\end{array}$ & $\begin{array}{c}\text { Espalhamento } \\
(\mathbf{m m})\end{array}$ \\
\hline 1,5 & 130,0 \\
2,0 & 142,5 \\
2,5 & 393,1 \\
3,0 & 448,7 \\
\hline
\end{tabular}

O teor ótimo de 2,5\% de superplastificante proporcionou uma consistência de aproximadamente $400 \mathrm{~mm}$, cuja fluidez apresentada demonstrou-se apropriada para a aplicação em compósitos com fibras vegetais devido à sua capacidade de adentrar o reforço natural contínuo.

\subsubsection{Propriedades da Matriz em Estado Endurecido}

A avaliação da matriz em seu estado endurecido foi realizada por meio de ensaios à compressão em idades diversas $(3,7,14,28,45$ e 90 dias) com o objetivo de aferir o ganho de resistência com o tempo. Os testes foram realizados em uma máquina de ensaio de compressão Controls, modelo 50-C46Z00, com capacidade de carga de $2000 \mathrm{kN}$. Para cada idade, três corpos de prova cilíndricos, de dimensões $100 \mathrm{~mm}$ x $50 \mathrm{~mm}$ (altura x diâmetro), foram submetidos à compressão sob uma taxa de deslocamento do pistão de $0,4 \mathrm{~mm} / \mathrm{min}$. Após a cura em câmara 
úmida, a superfície de cada uma das amostras foi regularizada por meio do faceamento de seu topo e base, de maneira a evitar acúmulo de tensões. A Figura 3-5 ilustra o equipamento e o posicionamento do corpo de prova durante o ensaio.

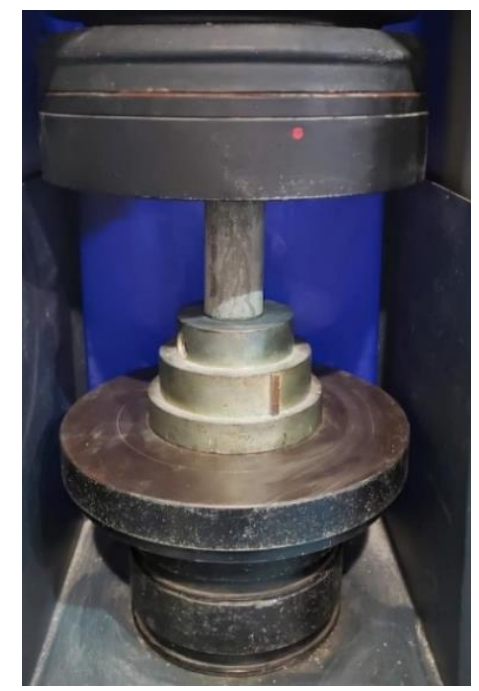

Figura 3-5: Ensaio de compressão do corpo de prova cilíndrico

A partir da força máxima aplicada, a resistência foi calculada por meio da razão entre força e área da seção transversal. O valor final da resistência à compressão para cada idade foi definido como a média entre as três amostras. Os resultados são explicitados na Figura 3-6, onde o desvio padrão dos valores de resistência são igualmente indicados:

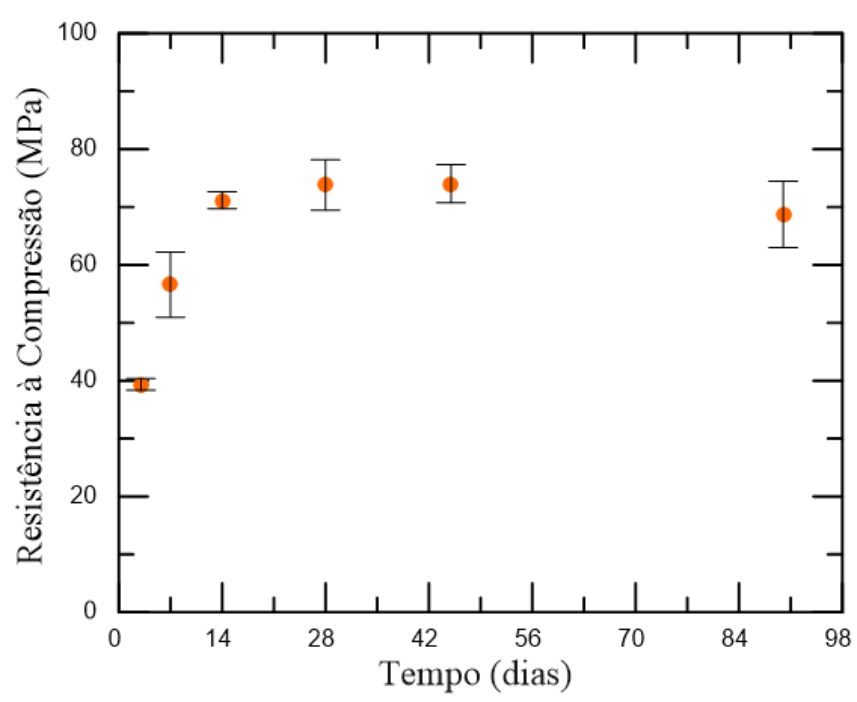

Figura 3-6: Resistência à compressão dos corpos de provas ao longo do tempo, em diferentes idades de cura 
Nota-se que a resistência apresentada pela matriz demonstra maior ganho entre 14 e 45 dias, apresentando uma média de $74 \mathrm{MPa}$. Tem-se que o ganho de resistência, apesar de não muito pronunciado, apresentou um alto valor médio e manteve certa estabilidade até os 90 dias. A substituição parcial do cimento detém uma parcela de tais efeitos positivos, uma vez que o metacaulim possui um caráter catalisador na hidratação do cimento, ao passo que a cinza volante influencia na trabalhabilidade da matriz (FERREIRA, 2012; LAGIER; KURTIS, 2007). Estudos anteriores (MELO FILHO et al., 2013; SILVA et al., 2010) corroboram influências positivas na durabilidade do compósito através da substituição parcial do cimento.

\subsection{Fibra de Curauá}

\subsubsection{Características Gerais e Beneficiamento}

O curauá é uma planta da região Amazônica, de nome científico Ananas comosus var. erectifolius - o que a classifica como pertencente à família do abacaxi (Ananas comosus). Suas folhas, eretas e planas, apresentam comprimento médio de 1,5 m, com largura de $5 \mathrm{~cm}$ e 0,5 cm de espessura (SILVA; AQUINO, 2008). A partir das mesmas, extraem-se fibras cujas características de baixo custo, leveza e desempenho mecânico satisfatório as tornam uma opção econômica e favorável a aplicações tecnológicas.

A fibras utilizadas nesse presente trabalho como reforço contínuo de compósitos cimentícios foram obtidas por meio de um projeto de parceria entre Fapespa/Tramontina/Embrapa/UFRA, baseado no cultivo de curauá em plantio florestal em Belém, Pará. De acordo com as informações fornecidas pela cartilha do projeto (ANDRADE et al., 2011), a colheita manual das folhas é realizada a cada três meses e produz uma média de 12 a 25 folhas por planta, contabilizando um peso médio de $2 \mathrm{~kg}$. O aproveitamento das folhas se dá de forma mecânica: a máquina desfibradeira é utilizada para a extração das fibras, as quais são submetidas à lavagem e posterior exposição ao Sol para secagem. Após o processamento, as fibras são classificadas e embaladas.

Uma vez adquiridas, as fibras apresentam-se aglomeradas entre si e com vestígios de resíduos de folhas, por efeito do pós-processamento. Assim, para torná- 
las mais adequadas à aplicação final no compósito, as fibras foram submetidas a um novo processo de limpeza e eliminação de impurezas.

Um dos possíveis processos de lavagem envolve o uso de água em alta temperatura, uma vez que se reduz a proporção de substâncias aderidas às paredes celulares de materiais lignocelulósicos (BENÍTEZ-GUERRERO et al., 2014). Dessa forma, as fibras de curauá foram submersas por 1 hora em água quente, sob temperatura controlada entre $70^{\circ}$ e $80^{\circ} \mathrm{C}$, sendo posteriormente expostas ao ar livre, sem a incidência direta de luz solar, para um processo de secagem natural por um período mínimo de 24 horas.

Após a secagem, deu-se início a um processo repetitivo de separação dos filamentos, de modo a evitar o agrupamento de fibras e facilitar a moldagem. O procedimento consiste no ato de pentear um conjunto de fibras por entre pregos dispostos lado a lado, cujo instrumento é ilustrado na Figura 3-7.

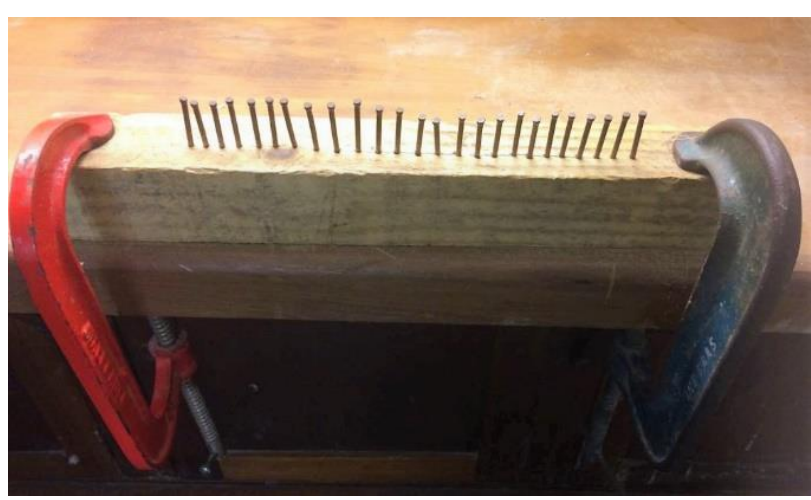

a)

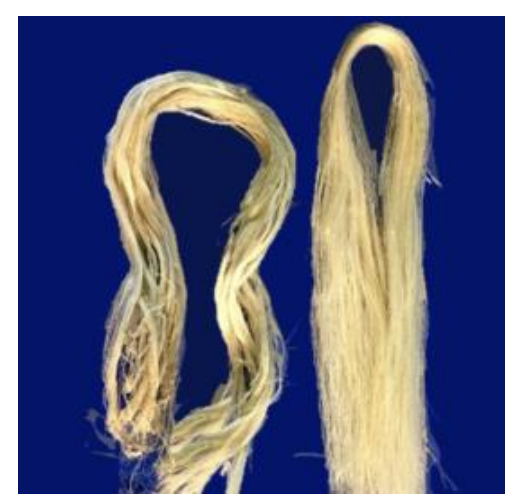

b)

Figura 3-7: Processo de separação dos filamentos: a) ferramenta utilizada para separar e pentear as fibras; b) diferença entre as fibras antes e após o processo

\subsubsection{Microestrutura}

Os filamentos de fibras naturais apresentam considerável variabilidade de formas, tamanhos e seções transversais, sendo necessário um método mais preciso para avaliar a área apresentada pelas amostras. Por conseguinte, para obter o diâmetro e a área transversal das fibras de curauá, utilizou-se da análise de imagens obtidas por microscopia. Dez filamentos de fibra, previamente imersos em água por 24 horas, foram cortados com lâmina de aço, perpendicularmente ao seu eixo, e 
fixados manualmente com fibra de carbono no aparato circular ilustrado na Figura 3-8-a.

Para melhor adequar as fibras à análise, é preciso aprimorar a condução de elétrons em sua superfície; para esse fim, uma fina camada de ouro foi depositada na área transversal das amostras por 30 segundos através do equipamento Sputter Coater SC-050, marca Balzers (Figura 3-8-b).

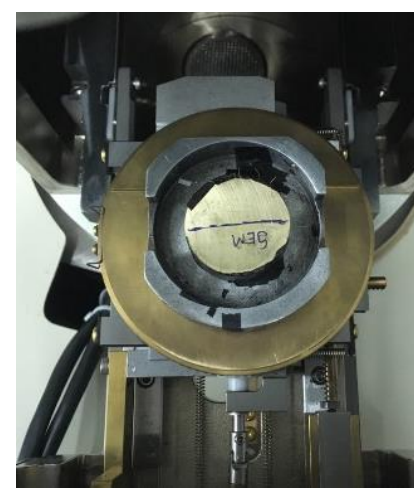

a)

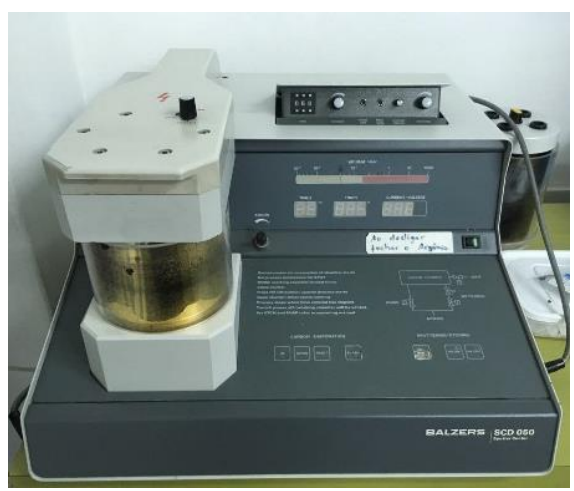

b)

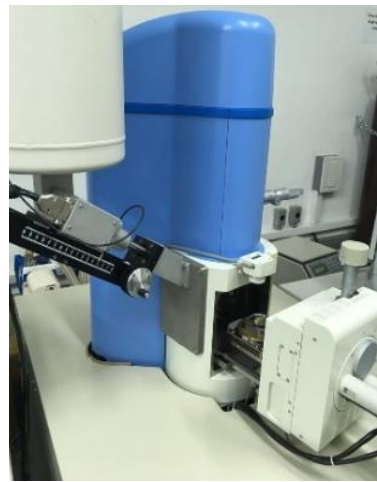

c)

Figura 3-8: Aparatos de análise: a) detalhe da disposição dos filamentos de fibras para a análise microscópica; b) equipamento utilizado para a deposição de camada de ouro na seção transversal das fibras; c) microscópio eletrônico de varredura (MEV) utilizado para a obtenção de imagens

Em seguida, os filamentos foram analisados em um microscópio eletrônico de varredura (MEV), JEOL JSM-6510LV, operando em uma faixa de tensões de aceleração de 10 a $30 \mathrm{kV}$. O processo de análise foi realizado no Laboratório de Microscopia Eletrônica do Departamento de Engenharia de Materiais da PUC-Rio. As imagens foram processadas pelo software ImageJ, o qual permite o cálculo da seção transversal das fibras através do contorno de suas respectivas áreas, como demonstrado pela Figura 3-9.

Os valores obtidos pela avaliação das seções transversais das fibras foram expressos na Tabela 3-2. As amostras demonstram resultados variáveis devido à diferença morfológica entre os filamentos, característica comum entre as fibras naturais. 


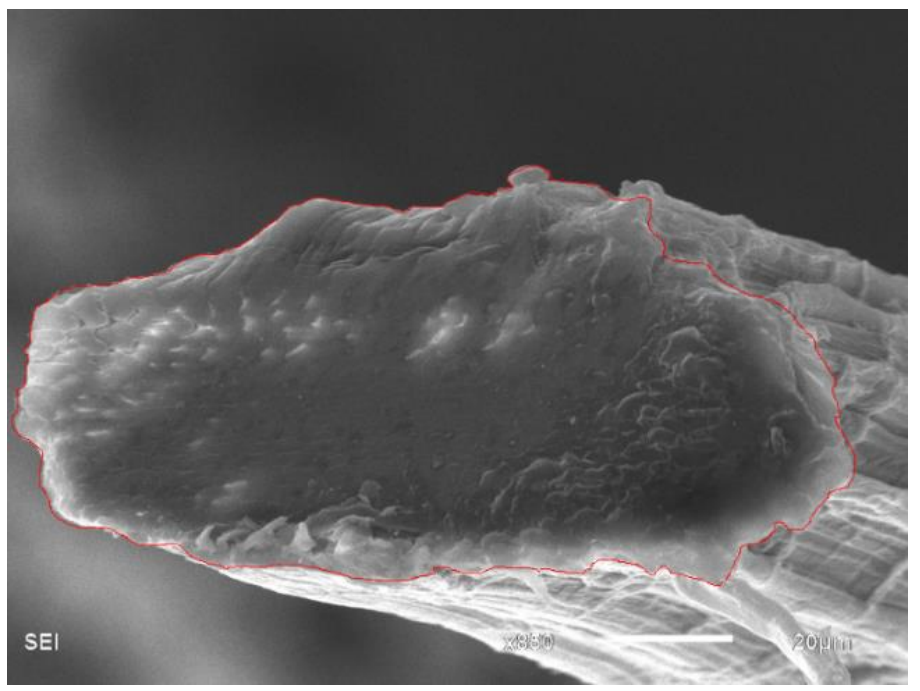

Figura 3-9: Contorno da seção transversal da fibra para o cálculo de sua área

Tabela 3-2: Seção transversal dos filamentos de curauá

\begin{tabular}{cc}
$\begin{array}{c}\text { Filamento } \\
\text { de } \\
\text { Fibra }\end{array}$ & $\begin{array}{c}\text { Área de Seção } \\
\text { Transversal } \\
\left(\mathbf{m m}^{\mathbf{2}} \mathbf{x} \mathbf{1 0}^{-\mathbf{3}}\right)\end{array}$ \\
\hline 1 & 1,45 \\
2 & 9,43 \\
3 & 5,14 \\
4 & 8,20 \\
5 & 3,41 \\
6 & 4,74 \\
7 & 5,35 \\
8 & 3,83 \\
9 & 4,55 \\
10 & 7,01 \\
Média & $\mathbf{5 , 3 1}$ \\
Desvio & $\mathbf{2 , 3 5}$ \\
Padrão & \\
\hline
\end{tabular}

Exemplos de imagens obtidas por microscopia são indicados na Figura 3-10, demonstrando diferentes aspectos da estrutura superficial da fibra de curauá. As micrografias detalham as fibrilas que compõem os filamentos, tal como as suas células de parênquima visíveis - distinguíveis pelas marcas transversais na estrutura longitudinal da fibra, Figura 3-10-b. A aproximação da seção transversal da fibra, 
na Figura 3-10-d, torna possível a identificação das paredes celulares e dos lúmens (cavidades centrais).

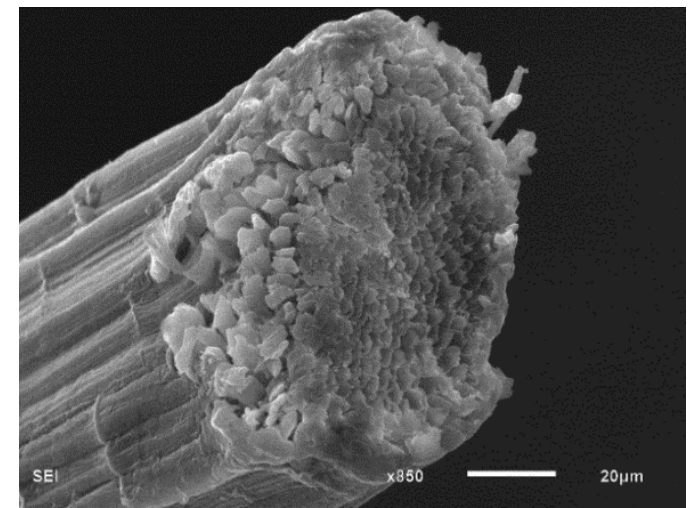

a)

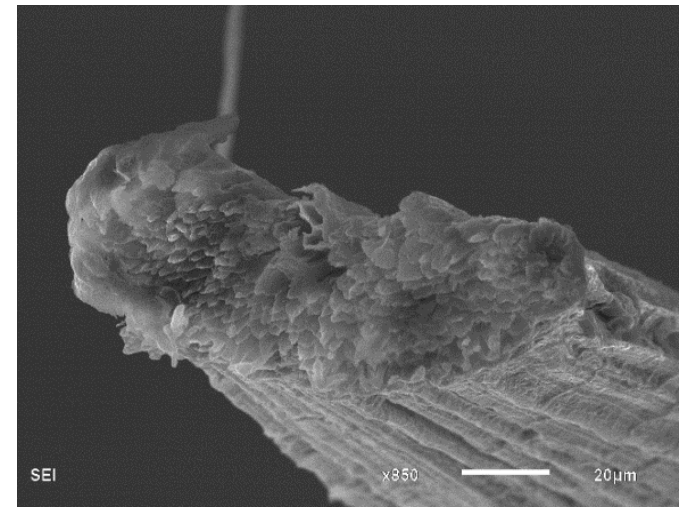

c)

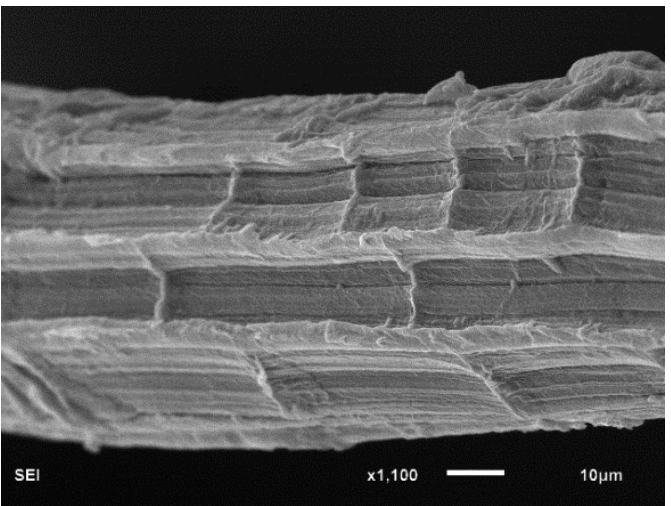

b)

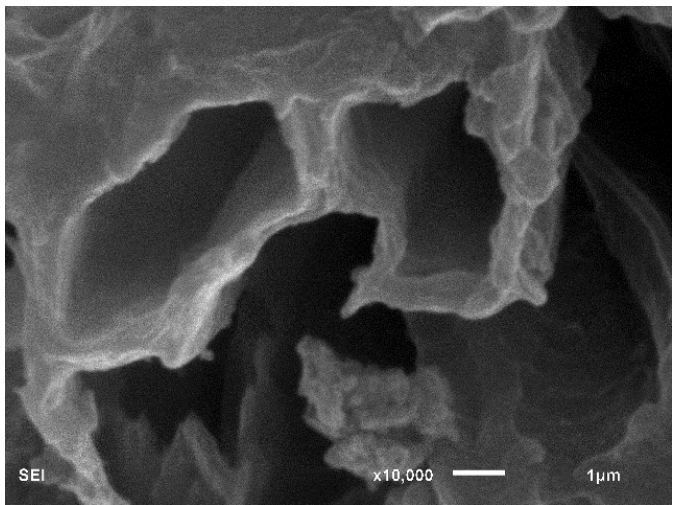

d)

Figura 3-10: Micrografias: a) seção transversal de amostra; b) lateral da fibra natural; c) seção transversal com morfologia diversa; d) detalhe da estrutura interna da fibra à esquerda, onde os lúmens são visíveis

\subsubsection{Resistência à Tração}

A avaliação das propriedades mecânicas das fibras de curauá foi realizada por meio de testes de tração direta de seus filamentos em uma máquina de ensaios universais MTS modelo 810, com capacidade de carga de $250 \mathrm{kN}$. Devido à sensibilidade do ensaio - uma vez que a força prevista pelo teste é muito inferior à ordem de grandeza englobada pelo sistema da máquina -, adicionou-se uma célula de carga de $100 \mathrm{~N}$ para maior precisão dos resultados.

O ensaio, realizado sob temperatura ambiente, envolveu 15 filamentos de fibras, os quais foram submetidos à limpeza sob alta temperatura, à secagem e à separação dos fios, como previamente descrito. O processo de preparo para o ensaio 
de tração seguiu as recomendações da norma ASTM C1557 (2014). As amostras foram fixadas em guias de papel cartão de maneira a evitar o esmagamento dos corpos de prova pelas garras da máquina. As bordas das guias foram cortadas para que as mesmas não influenciassem na tração das fibras, como ilustrado na Figura $3-11$.

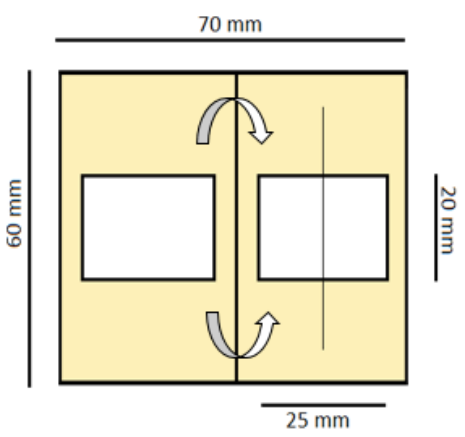

a)

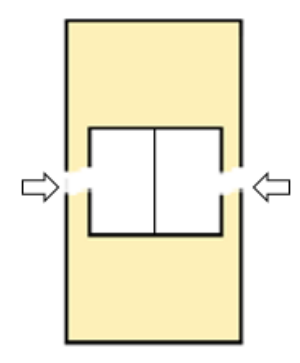

b)

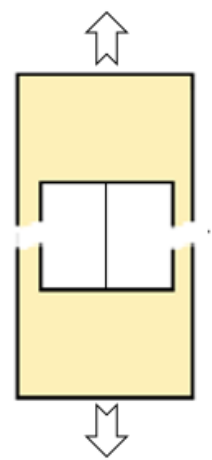

c)

Figura 3-11: Preparação da amostra: a) a fibra deve ser centralizada axialmente e a guia dobrada ao meio, fixando-se as partes por meio de cola aplicada em sua área interna; b) as bordas da guia devem ser cortadas imediatamente antes do ensaio; c) a fibra é tracionada sem influência da guia

O ensaio mecânico foi realizado a uma taxa de deslocamento de $0,1 \mathrm{~mm} / \mathrm{min}$, com um comprimento útil de $20 \mathrm{~mm}$. Um LVDT de $10 \mathrm{~mm}$ de curso foi acoplado ao aparato com o propósito de medir o alongamento da fibra, conforme ilustrado pela Figura 3-12.

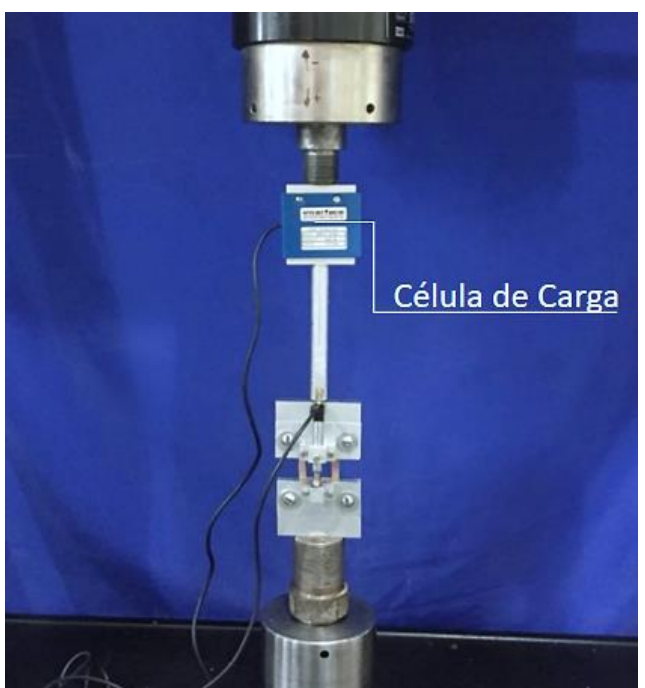

a)

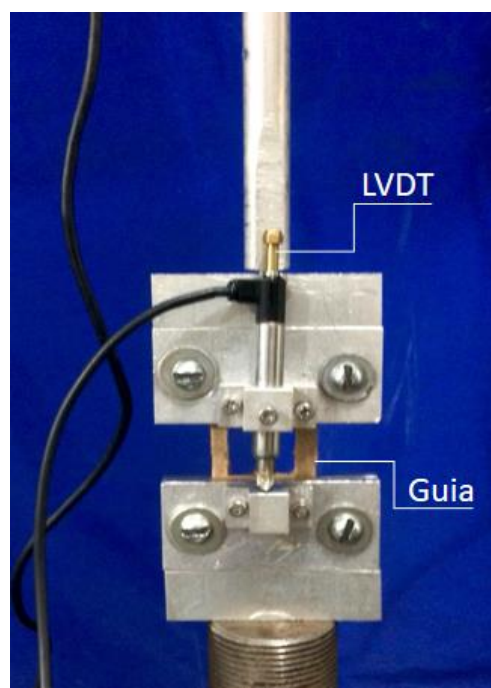

b)

Figura 3-12: Setup de tração da fibra: a) aparato geral; b) detalhe para as garras metálicas e o LVDT acoplado 
A resistência à tração é calculada pela relação entre força aplicada e área transversal. Similarmente, a tensão máxima atingida por cada corpo de prova é obtida por meio de:

$$
\sigma_{\text {máx }}=\frac{P_{\max }}{A}
$$

Onde:

$\sigma_{\text {máx }}=$ resistência máxima à tração $(\mathrm{MPa})$;

$\mathrm{P}_{\max }=$ força máxima atingida no ponto de fratura $(\mathrm{N})$;

$\mathrm{A}=$ área da seção transversal da fibra $\left(\mathrm{mm}^{2}\right)$;

A partir dos dados obtidos previamente por análise de imagens no item 3.3.2, é possível correlacionar a morfologia das fibras às suas propriedades mecânicas ao utilizar a área transversal média real dos filamentos para o cálculo de resistência à tração - no caso, $0,00531 \mathrm{~mm}^{2}$.

A deformação máxima da fibra, por sua vez, é calculada da seguinte forma:

$$
\varepsilon_{\text {máx }}=\frac{\delta \text { máx }}{L_{i}}
$$

Onde:

Emáx = deformação máxima da fibra $(\mathrm{mm} / \mathrm{mm})$;

$\delta_{\text {máx }}=$ deslocamento máximo atingido pela fibra $(\mathrm{mm})$;

$L_{i}=$ comprimento útil $(\mathrm{mm})$;

Tem-se que o deslocamento axial é medido pelo LVDT, ao passo que comprimento útil do teste é de $20 \mathrm{~mm}$. A Figura 3-13 demonstra, afinal, a relação entre a resistência à tração apresentada pela fibra e sua respectiva deformação. A curva tensão-deformação permite a determinação do módulo de elasticidade dos filamentos a partir de seu coeficiente angular na região elástica. As curvas de todos os filamentos ensaiados encontram-se no Apêndice A, Figura 8-2-a. 


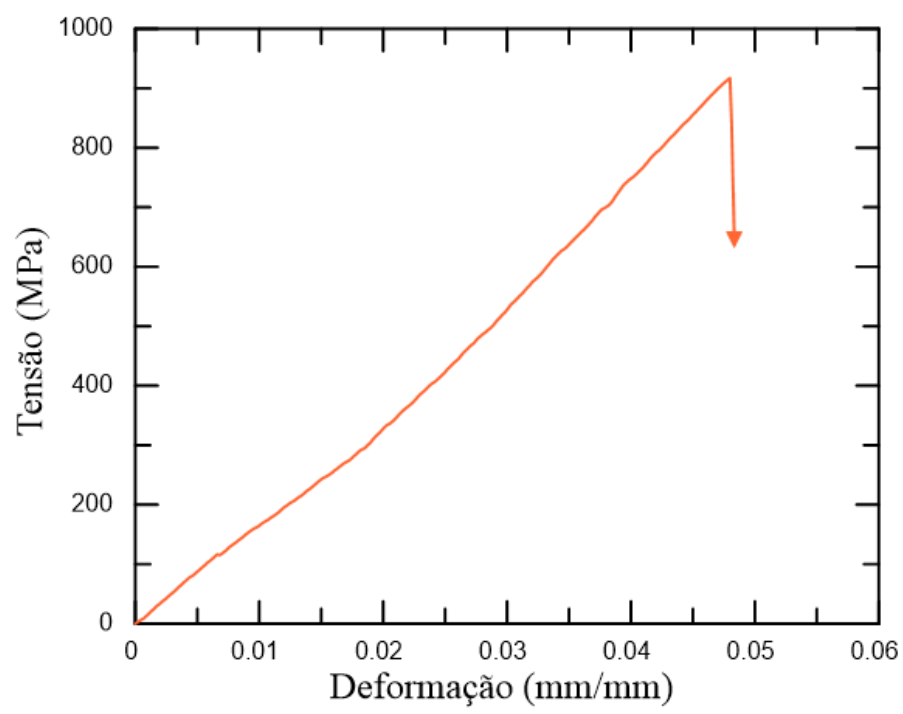

Figura 3-13: Curva tensão-deformação média da fibra de curauá

Os resultados da caracterização mecânica dos filamentos encontram-se detalhados na Tabela 3-3. A resistência à tração e o módulo de elasticidade apresentados mostram-se superiores aos de algumas fibras sintéticas, como o polipropileno, cuja resistência varia entre 400-550 MPa e o módulo de elasticidade detém 5,6 GPa, e o polietileno, com resistência variável entre 80-600 MPa e módulo de 5 GPa (BENTUR; MINDESS, 1990; FELEKOǦLU et al., 2009).

Tabela 3-3: Propriedades mecânicas dos filamentos de curauá

\begin{tabular}{ccc}
\hline Tensão & Deformação & Módulo de \\
Máxima & Máxima & Elasticidade \\
$(\mathbf{M P a})$ & $(\%)$ & $(\mathbf{G P a})$ \\
$867( \pm 389)$ & $4,9( \pm 0,5)$ & $14,5( \pm 4,6)$ \\
\hline
\end{tabular}

Apesar da alta variabilidade dos resultados obtidos, os mesmos encontramse de acordo com a literatura, como demonstra o estudo de Spinacé et al. (2009), que apresentou uma resistência à tração de $900( \pm 200) \mathrm{MPa}$, deformação aproximada de $3( \pm 1) \%$ e um módulo de elasticidade de $36( \pm 10)$ GPa para os filamentos de curauá avaliados. Comparativamente, para fibras de curauá com 0,004 $\mathrm{mm}^{2}$ de área transversal, Fidelis et al. (2013) obtiveram $543( \pm 260)$ MPa e $63,7( \pm 32,5) \mathrm{GPa}$ para a resistência à tração e módulo de elasticidade, respectivamente. Dittenberg (2012) aponta para uma variação de 87-1150 MPa e 11,8-96 GPa para as mesmas propriedades de fibras de curauá de fontes diversas. 
De igual maneira, as fibras ensaiadas apresentaram valores díspares, particularmente no que concerne ao módulo de elasticidade, o qual se mostrou inferior a referências da literatura (MONTEIRO et al., 2011; SILVA; AQUINO, 2008). A heterogeneidade das propriedades das fibras naturais é comum, podendo ocorrer inclusive na mesma plantação, e decorre do número de fatores influentes em suas características, como a estação de colheita, tipo do solo e condições do clima, conforme explicita Koronis et al. (2013). Deve-se considerar, igualmente, que há uma variabilidade associada à parte do curauá extraída para o processamento das fibras, já que seções diversas da planta podem apresentar rigidezes diferenciadas.

\subsubsection{Absorção e Dessorção de Água}

As fibras vegetais possuem considerável capacidade de incorporação de água devido à sua natureza porosa, sendo altamente influenciadas pelas condições do ambiente. Uma vez que a variação de volume decorrente de tal interação pode afetar o contato entre fibra-matriz no compósito, torna-se necessária a avaliação das propriedades higroscópicas da fibra ao absorver e dessorver (isto é, liberar) a água do meio. Os testes a seguir foram realizados de forma análoga ao proposto por Ferreira et al. (2015).

Três feixes de fibras, submetidos ao processo de limpeza mencionado anteriormente, foram pesados da mesma maneira que uma camada de tecido constituinte do compósito, isto é, 6,5 g. Para a avaliação da capacidade de absorção de água, os corpos de prova foram armazenados em estufa a $80^{\circ} \mathrm{C}$ até atingirem constância de massa. Posteriormente, os feixes de fibras foram submersos em água e submetidos a leituras de massa em intervalos de 2, 4, 6, 8, 10, 30, 60, 120, 180, 240 e 300 min. Os feixes foram retirados da água para cada medida, dispostos em um pano suave de algodão e cobertos com um segundo pano de mesmo material por 30 segundos, sendo pesados em seguida.

O ensaio de dessorção foi executado logo após, com os mesmos feixes de fibras saturados. As amostras foram dispostas em um pano para retirar o excesso d'água e depois armazenadas em estufa a $80^{\circ} \mathrm{C}$ para novas leituras de massa. As medidas foram realizadas após 10, 30, 60, 90 e $120 \mathrm{~min}$, repetindo-se o processo de 
disposição das fibras em panos por 30 segundos antes de cada leitura. A variação de massa das fibras, em porcentagem, calculada a partir dos ensaios de absorção e dessorção de água, é ilustrada na Figura 3-14.

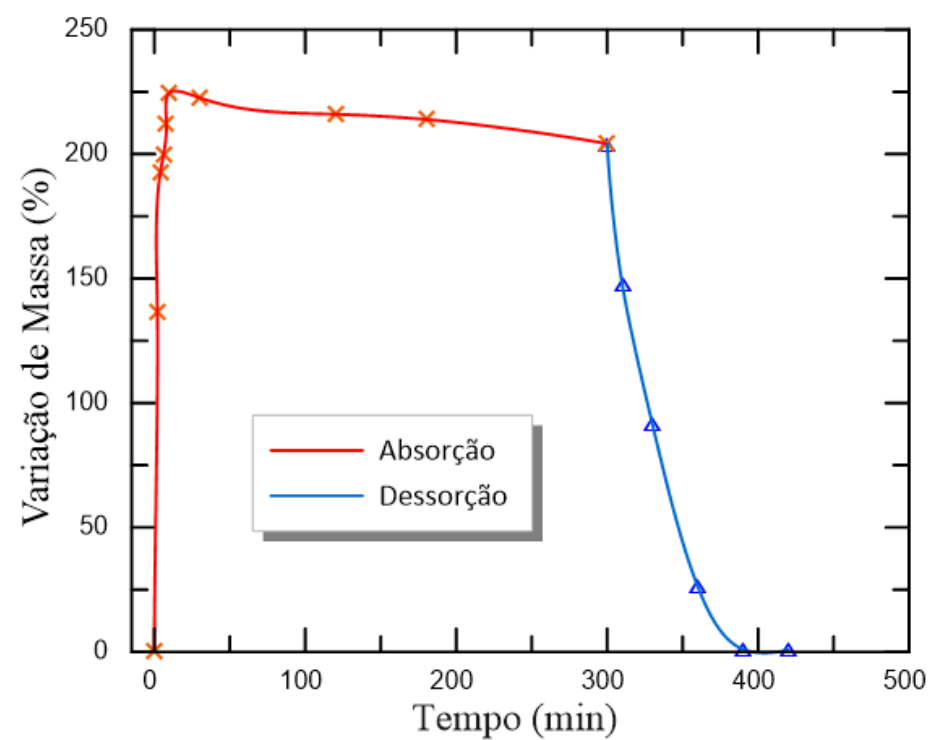

Figura 3-14: Relação de perdas e ganhos de massa da fibra devido a processos de absorção e dessorção de água

As amostras testadas atingiram sua capacidade máxima de absorção entre 10 e 30 minutos, alcançando aproximadamente $230 \%$ de ganho em massa. A capacidade de dessorção de água dos filamentos apresentou uma queda expressiva e constante, alcançando uma perda de $180 \%$ em 60 minutos. Ao comparar os resultados com a literatura, tem-se que Ferreira et al. (2015) obtiveram um ganho significativo de $350 \%$ de massa, ao passo que Lopes et al. (2011) registraram um valor de $92 \%$ em fibras não tratadas imersas por $24 \mathrm{~h}$.

Observa-se um patamar na curva de absorção após o valor máximo de variação de massa. Isso se deve à saturação da parede celular do curauá, após a qual a fibra não aumenta o seu volume. No caso, não houve uma estabilização plena do patamar devido a possíveis variações no processo de redução do excesso de água das fibras antes de sua pesagem.

Em relação à taxa de absorção, a qual mostrou-se inferior à obtida por Ferreira et al. (2015), há uma série de elementos que podem afetar a capacidade da fibra de absorver a água do meio. De acordo com Spinacé et al. (2009), o teor de umidade da fibra depende das condições atmosféricas, do tipo da fibra, da idade da planta e do solo no qual foi cultivada. Assim, tal disparidade é aceitável. 


\subsection{Concreto Celular Autoclavado}

\subsubsection{Características Técnicas}

Os blocos de CCA utilizados neste trabalho são fornecidos pela PRECON, com dimensões comerciais de $60 \mathrm{~cm}$ x $30 \mathrm{~cm}$ x $10 \mathrm{~cm}$ e $60 \mathrm{~cm}$ x $30 \mathrm{~cm}$ x 7,5 cm (comprimento $\mathrm{x}$ largura $\mathrm{x}$ altura). De acordo com a ficha disponibilizada pela fábrica (PRECON INDUSTRIAL S/A, 2017), as características técnicas dos blocos resumem-se às informações da Tabela 3-4.

Tabela 3-4: Características técnicas dos blocos de CCA

\section{Características Técnicas Gerais}

Densidade: $\leq 550 \mathrm{~kg} / \mathrm{m}^{3}$

Peso específico seco: $5,0 \mathrm{KN} / \mathrm{m}^{3}$

Resistência à tração por flexão:

$0,8 \mathrm{kN} / \mathrm{m}^{2}$

Resistência à compressão: $2,5 \mathrm{KN} / \mathrm{m}^{2}$

Peso específico de cálculo: $5,8 \mathrm{kN} / \mathrm{m}^{3}$

Coeficiente de dilatação: $0,008 \mathrm{~mm} / \mathrm{m}^{\circ} \mathrm{C}$
Coeficiente de condutibilidade térmica: $0,16 \mathrm{~W} / \mathrm{m}^{\circ} \mathrm{C}$

Módulo de elasticidade: $2300 \mathrm{~N} / \mathrm{mm}^{2}$

Ponto de fusão: $500^{\circ} \mathrm{C}$

Fonte: Precon Industrial S/A (2017)

Para avaliar as propriedades dos blocos e obter dados mais precisos que os de fábrica, ensaios de caracterização foram realizados de acordo com a norma ASTM C1693 (2009), cujas especificações englobam testes relativos à densidade seca, resistência à compressão e módulo de elasticidade.

A norma classifica os corpos de prova manufaturados de CCA de acordo com a sua classe de resistência, como demonstrado na Tabela 3-5. Em comparação ao tamanho de fábrica, os blocos utilizados detêm variações de suas dimensões, particularmente devido à irregularidade da superfície e fragilidade das faces externas. Consequentemente, o tamanho de cada corpo de prova foi registrado antes de cada ensaio por meio de um paquímetro. 
Tabela 3-5: Requisitos e classes para unidades fabricadas de concreto celular autoclavado

\begin{tabular}{cccc}
\hline & Resistência à & Densidade & Limites de \\
Classe & $\begin{array}{c}\text { Compressão } \\
\text { (MPa) }\end{array}$ & $\begin{array}{c}\text { Aparente Seca } \\
\text { Nominal } \\
\left(\mathbf{k g} / \mathbf{m}^{\mathbf{3}}\right)\end{array}$ & $\begin{array}{c}\text { Densidade } \\
\left(\mathbf{k g} / \mathbf{m}^{\mathbf{3}}\right)\end{array}$ \\
\hline CCA-2 & 2,0 & 400 & $350-450$ \\
& & 500 & $450-550$ \\
CCA-4 & 4,0 & 500 & $450-550$ \\
& & 600 & $550-650$ \\
& & 700 & $650-750$ \\
CCA-6 & 6,0 & 800 & $750-850$ \\
& & 600 & $550-650$ \\
& & 700 & $650-750$ \\
& & 800 & $750-850$ \\
\hline
\end{tabular}

Fonte: adaptado de ASTM C-1693 (2009).

\subsubsection{Teor de Umidade Aparente}

A verificação do teor de umidade e densidade aparente seca dos blocos de CCA foi avaliada em concordância com a ASTM C1693 (2009), com modificações adicionais. Os corpos de prova consistiram em 3 cubos de $100 \mathrm{~mm}$ de aresta, extraídos dos blocos por meio de uma serra de corte circular diamantado Coretest Systems RCSS-415. As dimensões de cada amostra foram medidas por meio de um paquímetro com precisão de $0,1 \mathrm{~mm}$, sendo o seu volume calculado através da média dos valores de comprimento, largura e altura de faces opostas.

Os corpos de prova, uma vez preparados, foram pesados e em seguida armazenados em uma estufa a $105 \pm 5^{\circ} \mathrm{C}$ por um tempo mínimo de 24 horas e até que duas pesagens consecutivas demonstrassem uma perda igual ou inferior a $0,2 \%$ da massa obtida anteriormente. O teor de umidade, calculado a partir da perda de massa por secagem, é definido pela relação a seguir: 


$$
T U=\frac{(A-B)}{B} \times 100
$$

Onde:

$\mathrm{TU}=$ teor de umidade $(\%)$;

$\mathrm{A}=$ massa amostrada úmida $(\mathrm{kg})$;

$\mathrm{B}=$ massa seca da amostra $(\mathrm{kg})$.

O teor de umidade do lote é definido como a média dos valores individuais, sendo aproximado ao $0,1 \%$ mais próximo. A densidade aparente seca, por sua vez, é calculada pela relação abaixo:

$$
\gamma=\frac{B}{V}
$$

Onde:

$\mathrm{B}=$ massa seca da amostra $(\mathrm{kg})$;

$\mathrm{V}=$ volume da amostra $\left(\mathrm{m}^{3}\right)$

A densidade aparente seca do bloco foi calculada como a média dos valores individuais das densidades de cada amostra, sendo o seu valor aproximado aos 5 $\mathrm{kg} / \mathrm{m}^{3}$ mais próximos.

Tabela 3-6: Características físicas, densidade e umidade dos corpos de provas cúbicos de CCA

\begin{tabular}{cccccc}
\hline $\begin{array}{c}\text { Corpo de } \\
\text { Prova }\end{array}$ & $\begin{array}{c}\text { Massa } \\
\text { Amostrada } \\
(\mathbf{k g})\end{array}$ & $\begin{array}{c}\text { Massa } \\
\text { Seca } \\
(\mathbf{k g})\end{array}$ & $\begin{array}{c}\text { Volume } \\
\left(\mathbf{m}^{\mathbf{3}}\right)\end{array}$ & $\begin{array}{c}\text { Teor de } \\
\text { Umidade } \\
(\boldsymbol{\%})\end{array}$ & $\begin{array}{c}\text { Densidade } \\
\text { Seca } \\
\left(\mathbf{k g} / \mathbf{m}^{\mathbf{3}}\right)\end{array}$ \\
\hline 1 & 0,497 & 0,479 & 0,00102 & 3,6 & 470 \\
2 & 0,485 & 0,469 & 0,00100 & 3,6 & 467 \\
3 & 0,492 & 0,460 & 0,00099 & 7,0 & 466 \\
\hline
\end{tabular}

Dadas as aproximações, os três corpos de provas ensaiados apresentaram teor de umidade médio de $4,7( \pm 1,9) \%$ e densidade aparente seca média de 470 $( \pm 2,3) \mathrm{kg} / \mathrm{m}^{3}$. 


\subsubsection{Estrutura Porosa}

Conforme previamente explicitado no item 2.3.2, o sistema de poros do concreto celular autoclavado está relacionado a inúmeras propriedades do material, como a resistência e a permeabilidade apresentadas pelo mesmo. De forma a caracterizar a estrutura porosa dos blocos de CCA, imagens foram obtidas por meio de um microscópio estereoscópio Nikon modelo SMZ800N, indicado na Figura 3-15.

Amostras de $10 \mathrm{~mm}$ de espessura e $50 \mathrm{~mm}$ de diâmetro foram utilizadas para a análise da estrutura porosa. As imagens obtidas a partir de diferentes aproximações do microscópio encontram-se na Figura 3-16. Nota-se que os poros visíveis adquirem formato aproximadamente esférico, apesar de deterem tamanhos diversos.

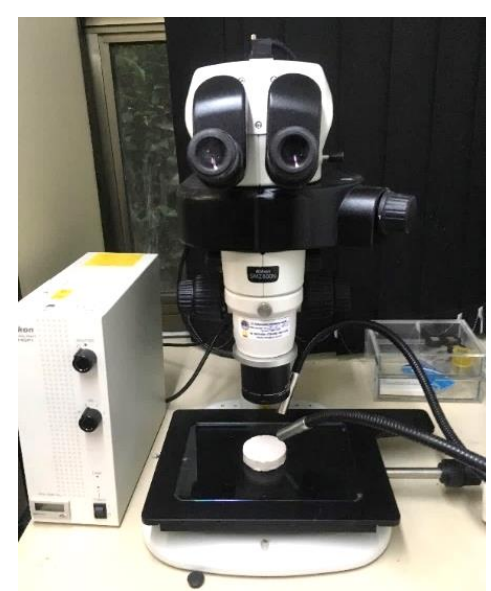

Figura 3-15: Equipamento utilizado para analisar a estrutura porosa das amostras de CCA

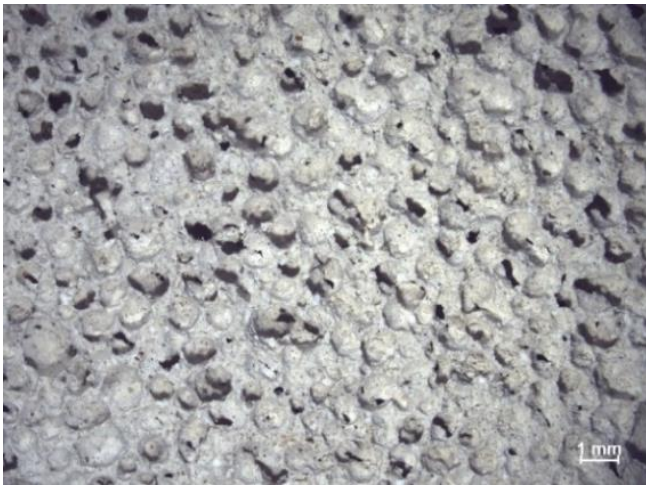

a)

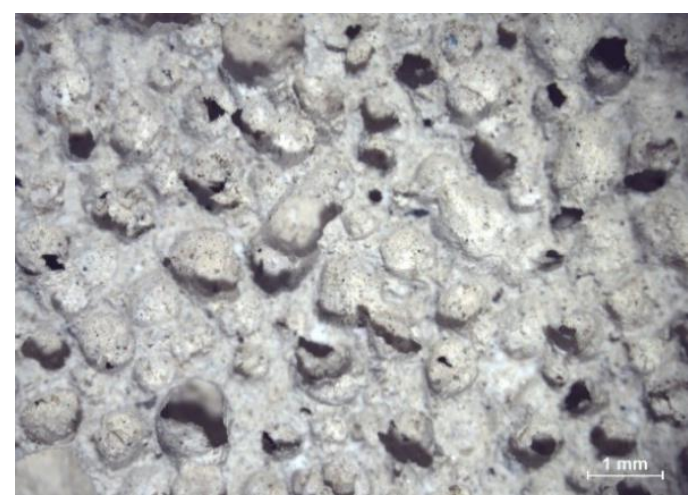

b)

Figura 3-16: Imagens obtidas da superfície do CCA: a) visão geral da distribuição e quantidade dos poros; b) detalhe para os poros de ar e seu formato esférico 
A fim de avaliar a distribuição e raios dos poros com base nas imagens obtidas, o software ImageJ foi utilizado para o cálculo da área, tal como para a contabilização do número de poros para a dada área da amostra. O processo, similar ao descrito no item 3.3.2, baseou-se no contorno manual dos poros para a estimativa de suas áreas individuais em três amostras. Para a definição da média de poros por área, utilizou-se um recurso manual de contabilização de pontos no Software.

Diante dos corpos de prova analisados, inferiu-se a existência de 2,2 poros para cada $\mathrm{mm}^{2}$ da amostra. Ademais, os poros apresentaram valores médios de área de $0,4 \mathrm{~mm}^{2}$, com variações entre $0,05-0,9 \mathrm{~mm}^{2}$, o que implica em raios entre 0,1 0,5 mm. O tamanho inferido está de acordo com a literatura, uma vez que os poros de ar, resultantes da expansão do material após o processo de inserção de vazios, possuem um raio entre 50 a $500 \mu \mathrm{m}$ (TADA; NAKANO, 1983). Poros de menor tamanho, como os microporos, não são visíveis através da análise devido à limitação do alcance de imagem do equipamento.

Tem-se que o tamanho dominante dos poros está associado à densidade do concreto celular autoclavado utilizado, uma vez que ele tende a aumentar conforme a densidade decresce. As amostras, de densidade previamente calculada, estão inclusas na classe 2 de referência do CCA, como indicado na Tabela 3-5, o que representa uma densidade inferior a $550 \mathrm{~kg} / \mathrm{m}^{3}$ e, portanto, uma alta incidência de poros e resistência à compressão reduzida. De acordo com Prim e Wittmann (1983), para corpos de prova de CCA com essa faixa de densidade, o volume de poros de ar introduzidos artificialmente corresponde a aproximadamente $53 \%$ dos $87 \%$ de porosidade total do material.

\subsubsection{Resistência à Compressão}

A umidade detém influência considerável nas propriedades do concreto celular autoclavado, sendo particularmente manifesta em sua relação com a resistência à compressão do material. De acordo com Wittmann (1983), a secagem completa das amostras permite um crescimento de $40 \%$ a $70 \%$ da resistência à compressão. O módulo de elasticidade em compressão, ainda que detenha diferença menos considerável, apresenta acréscimos de até $15 \%$ em condições secas. Dessa 
forma, é necessária a avaliação do teor de umidade das amostras antes de submetêlas a ensaios mecânicos.

De acordo com as recomendações da norma ASTM C1693 (2009), a resistência à compressão do concreto celular autoclavado deve ser avaliada em três corpos de prova cúbicos de $100 \mathrm{~mm}$ de aresta, extraídos por meio de corte seco e condicionados a um teor de umidade entre 5 e $15 \%$ em massa. De maneira a atingir o teor desejado, as amostras cúbicas foram secas em estufa sob uma temperatura de $70^{\circ} \mathrm{C}$, demandando aproximadamente $24 \mathrm{~h}$ para alcançar a faixa de umidade almejada. O teor de umidade do bloco é considerado como a média dos valores obtidos dos três corpos de prova analisados. Após condicionamento, os corpos de prova apresentaram um teor de umidade médio de $11,7( \pm 0,4) \%$ antes do ensaio à compressão.

Uma vez sob condições de umidade adequadas, os corpos de prova, com faces devidamente planas, foram ensaiados em uma máquina de compressão Controls C46Z00, como ilustrado na Figura 3-17. Aplicou-se metade da carga máxima prevista a $0,03 \mathrm{MPa} / \mathrm{s}$, sendo o restante da carga aplicado a $0,015 \mathrm{MPa} / \mathrm{s}$ até a ruptura. A velocidade de ensaio foi definida com base no momento de ruptura do corpo de prova, o qual deveria romper entre 1 e 2 minutos após o início do ensaio, conforme recomendado pela norma.

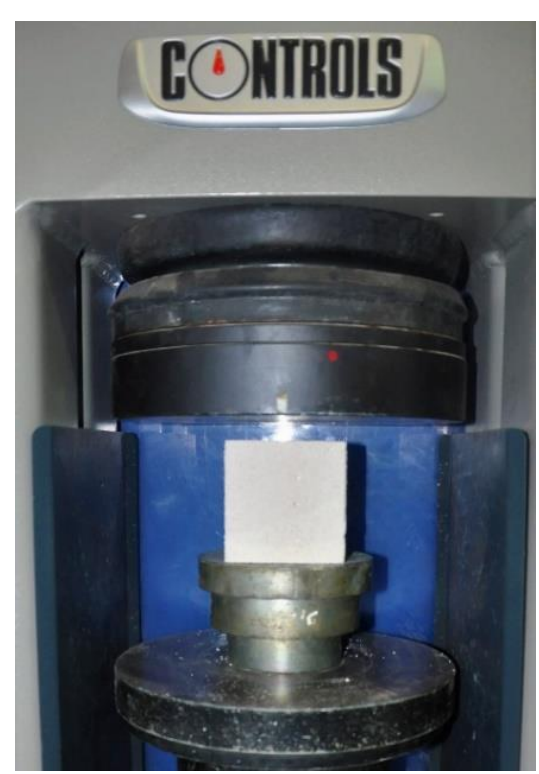

Figura 3-17: Cubo de CCA centralizado na máquina de compressão, antes da aproximação do pistão 
A resistência à compressão é dada pela relação entre força máxima e área transversal dos corpos de prova:

$$
f=\frac{P}{A}
$$

Onde:

$f=$ resistência à compressão do corpo de prova (MPa);

$\mathrm{P}=$ força máxima suportada $(\mathrm{N})$;

$\mathrm{A}=$ área da seção transversal comprimida $\left(\mathrm{mm}^{2}\right)$.

Tabela 3-7: Desempenho do CCA em ensaio à compressão

\begin{tabular}{ccccc}
\hline $\begin{array}{c}\text { Corpo } \\
\text { de }\end{array}$ & $\begin{array}{c}\text { Área } \\
\text { Pransversal } \\
\left(\mathbf{m m}^{\mathbf{2}}\right)\end{array}$ & $\begin{array}{c}\text { Força } \\
\text { Máxima } \\
(\mathbf{N})\end{array}$ & $\begin{array}{c}\text { Resistência à } \\
\text { Compressão } \\
(\mathbf{M P a})\end{array}$ & $\begin{array}{c}\text { Teor de } \\
\text { Umidade } \\
(\boldsymbol{\%})\end{array}$ \\
\hline 1 & 9900 & 22000 & 2,22 & 11,3 \\
2 & 9727 & 22900 & 2,35 & 11,6 \\
3 & 9900 & 22600 & 2,28 & 12,1 \\
\hline
\end{tabular}

As amostras ensaiadas apresentaram uma resistência à compressão de 2,3 $( \pm 0,07) \mathrm{MPa}$. De acordo com Narayanan e Ramamurthy (2000a), para uma densidade de $400 \mathrm{~kg} / \mathrm{m}^{3}$, a resistência à compressão do CCA varia de 1,3-2,8 MPa. Essa faixa de valores é condizente com a média obtida.

\subsubsection{Módulo de Elasticidade}

A determinação do módulo de elasticidade, em ensaio de compressão axial dos corpos de prova, foi realizada em uma máquina de ensaios universais MTS modelo 810, com capacidade de carga de $500 \mathrm{kN}$. Corpos de prova cilíndricos com altura de $150 \mathrm{~mm}$ e largura (diâmetro) de $75 \mathrm{~mm}$ foram utilizados, de modo a respeitar uma razão altura/diâmetro de 2 . Os corpos de provas foram extraídos dos blocos por meio de uma perfuratriz diamantada Hilti, sendo posteriormente ajustados à altura desejada através de uma serra de corte seco. As amostras foram armazenadas em estufa a $70 \pm 5^{\circ} \mathrm{C}$, alcançando um teor de umidade médio de 4,2 $( \pm 0,4) \%$. 
De maneira a medir o deslocamento vertical dos corpos de prova, dois transdutores de deslocamento variável linear (LVDT) de $5 \mathrm{~mm}$ foram acoplados à lateral de anéis acrílicos concêntricos ao corpo de prova, conforme ilustrado na Figura 3-18-b. Adotou-se uma taxa de deslocamento de $0,1 \mathrm{~mm} / \mathrm{min}$ para o ensaio.

O módulo de elasticidade é calculado a partir do coeficiente angular da curva de tensão-deformação em sua região linear. A tensão é ditada pela relação entre a força $(\mathrm{N})$ e a área sobre a qual é aplicada $\left(\mathrm{mm}^{2}\right)$. A deformação é dada pela razão entre deslocamento $(\mathrm{mm})$, obtido a partir da média dos valores dos LVDTs, e o comprimento de medição dos mesmos (mm), L0, indicado na Figura 3-18-a.

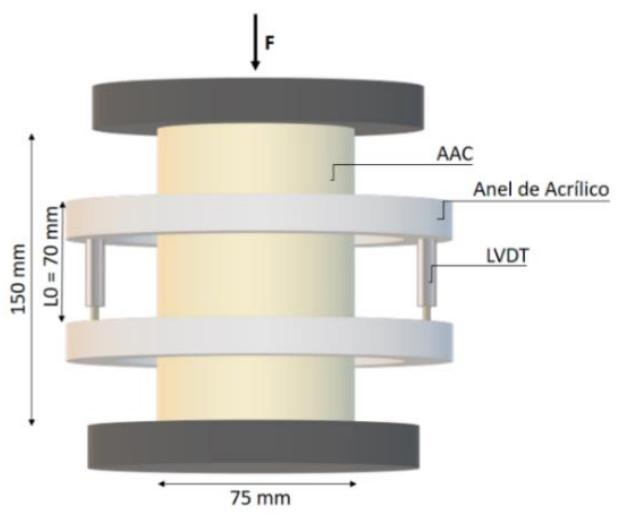

a)

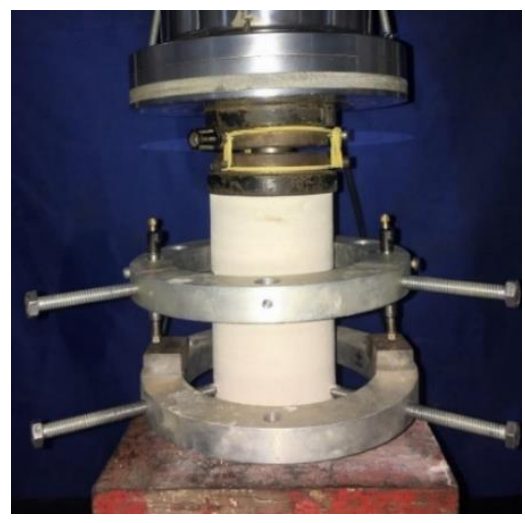

b)

Figura 3-18: Ensaio de compressão axial: a) detalhe das dimensões e componentes do setup; b) arranjo experimental

A curva típica é demonstrada na Figura 3-19 e os resultados explicitados na Tabela 3-8. As curvas restantes encontram-se no apêndice A, Figura 8-1-a.

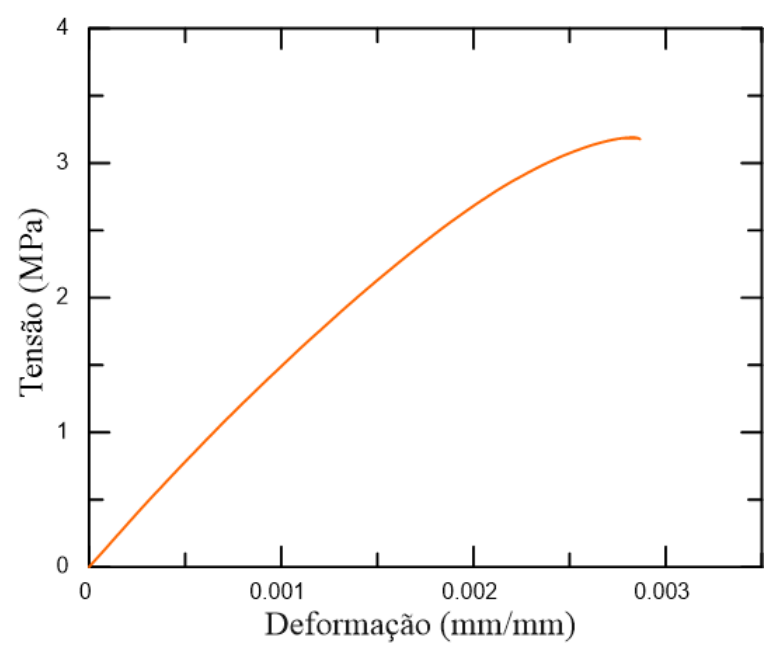

Figura 3-19: Relação tensão-deformação para corpo de provas de CCA em compressão 
Tabela 3-8: Propriedades mecânicas do CCA

\begin{tabular}{ccc}
\hline $\begin{array}{c}\text { Tensão } \\
\text { Máxima } \\
(\mathbf{M P a})\end{array}$ & $\begin{array}{c}\text { Deformação } \\
\text { Máxima } \\
(\mathbf{m m} / \mathbf{m m})\end{array}$ & $\begin{array}{c}\text { Módulo de } \\
\text { Elasticidade } \\
(\mathbf{G P a})\end{array}$ \\
\hline $3,26( \pm 0,16)$ & $0,0029( \pm 0,0003)$ & $1,49( \pm 0,01)$ \\
\hline
\end{tabular}

Comparativamente, Uddin et al. (2006) obtiveram um módulo de elasticidade de 2,14 GPa para blocos de CCA com densidade de $560 \mathrm{~kg} / \mathrm{m}^{3}$. Chen et al. (2013) obtiveram um módulo de 1,70 GPa para blocos com densidade de 461 $\mathrm{kg} / \mathrm{m}^{3}$.

\subsubsection{Resistência à Flexão}

A avaliação da resistência à flexão do concreto celular autoclavado foi realizada de acordo com a norma BS EN 1351 (1997), modificada conforme necessidade. A propriedade mecânica é avaliada a partir da aplicação de um momento fletor, por meio de um carregamento de dois pontos, no terço médio de um corpo de prova simplesmente apoiado. De acordo com a norma, o vão, 1, deve ser igual a $3 \mathrm{~h}$, onde h é a altura nominal dos corpos de prova - no caso, $75 \mathrm{~mm}$, como indicado na seção 3.4.1. Os roletes de carregamento devem ser espaçados igualmente em relação ao roletes de suporte, distanciados por uma extensão h, como demonstra a Figura 3-20 e ilustra a Figura 3-22-a. Utilizou-se areia peneirada umedecida para regularizar a superfície abaixo dos roletes de carregamento.
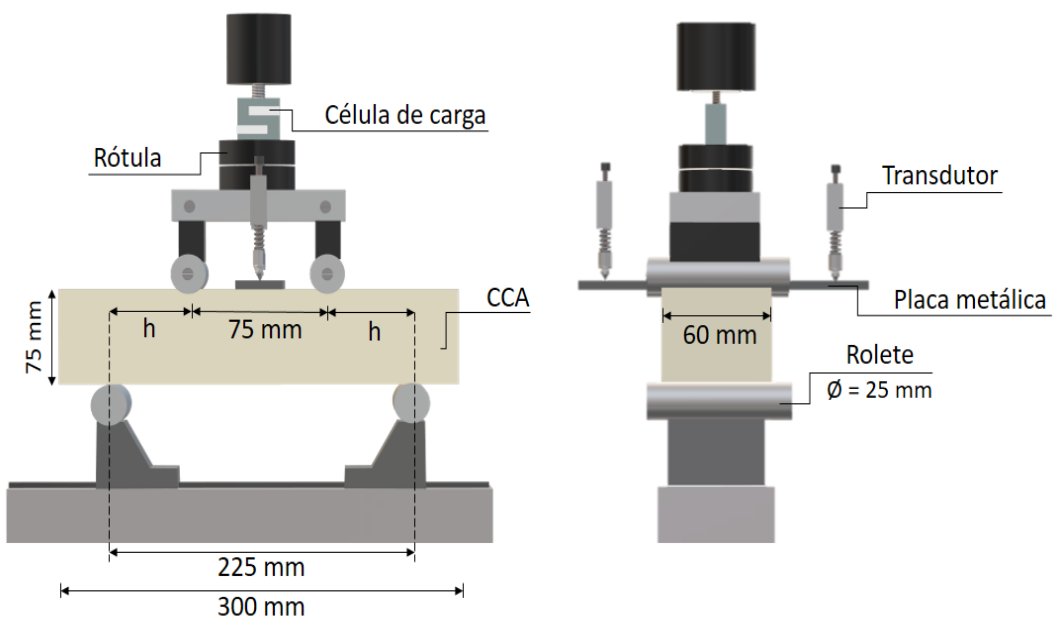

Figura 3-20: Imagem esquemática das dimensões do corpo de prova, comprimento do vão e elementos do arranjo para o ensaio de flexão a quatro pontos 
Blocos de $300 \mathrm{~mm}$ x $60 \mathrm{~mm}$ x $75 \mathrm{~mm}$ (comprimento x largura x altura) foram utilizados para o ensaio e suas dimensões medidas por meio de paquímetro com precisão de 0,1 mm. Dois transdutores Gefran, com $10 \mathrm{~mm}$ de comprimento, foram utilizados para medir o deslocamento vertical dos corpos de provas. Uma célula de carga de capacidade de $2,5 \mathrm{kN}$ foi acoplada ao equipamento para a obtenção de dados mais precisos, tendo-se em vista os pequenos valores de força previstos para a flexão do material. O aparato experimental encontra-se na Figura 3-22-a. Antes do ensaio, os corpos de prova foram secos em estufa a $60^{\circ} \mathrm{C}$ pelo tempo necessário (usualmente 24h) até atingirem um teor de umidade entre 5 e $15 \%$. Posteriormente, os mesmos foram armazenados em temperatura ambiente até atingirem o equilíbrio.

De modo a verificar o aparecimento e a abertura de fissuras, ensaios de flexão com entalhe foram igualmente realizados. Similarmente, blocos de $300 \mathrm{~mm}$ x $60 \mathrm{~mm}$ x $75 \mathrm{~mm}$, condicionados a um teor de umidade entre 5 e $15 \%$, foram utilizados na configuração de flexão a quatro pontos com um comprimento de vão de $225 \mathrm{~mm}$ e um entalhe de $10 \mathrm{~mm}$. Dois transdutores Gefran de $10 \mathrm{~mm}$ de curso foram utilizados para a avaliação do deslocamento axial, ao passo que o clip gage foi empregado para o controle da abertura do entalhe (CMOD), conforme esquematizado na Figura 3-21 e ilustrado na Figura 3-22-b.
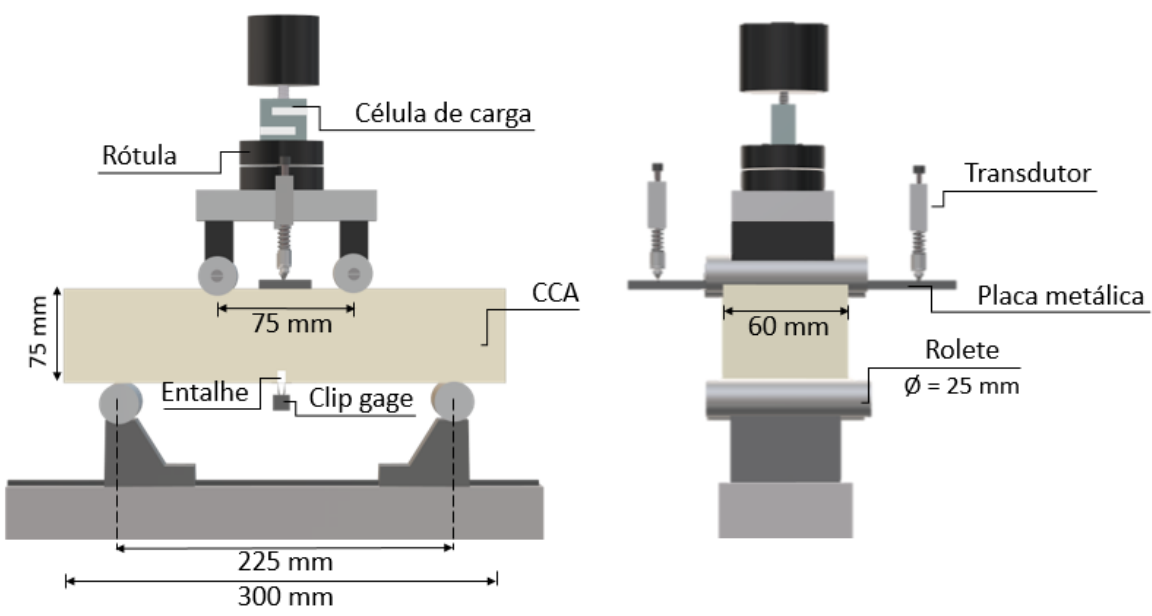

Figura 3-21: Esquema de flexão a quatro pontos, com entalhe de $10 \mathrm{~mm}$ de altura e $5 \mathrm{~mm}$ de espessura 


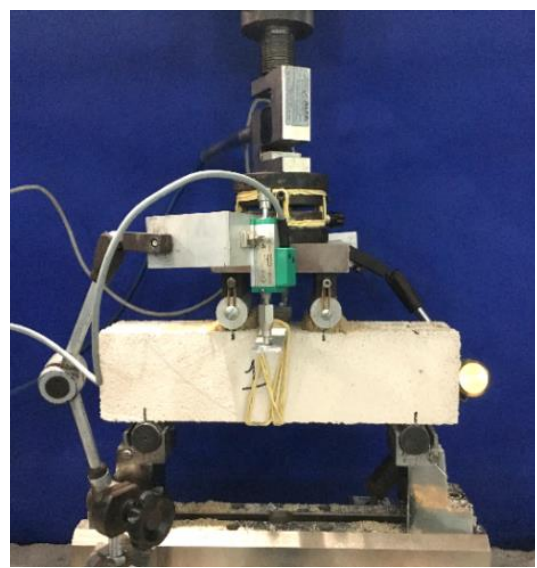

a)

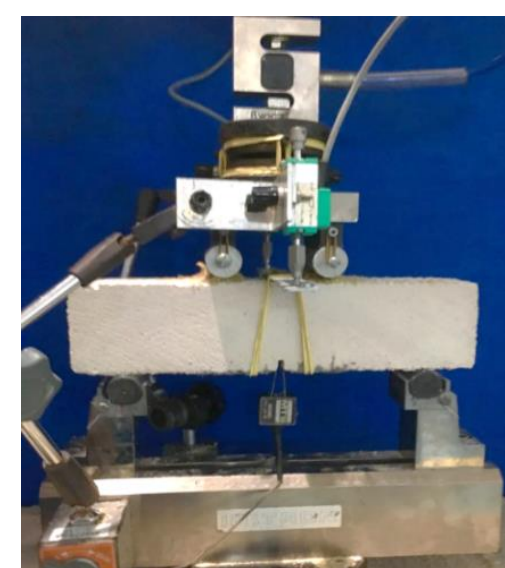

b)

Figura 3-22 Setup de flexão a quatro pontos de CCA: a) sem entalhe; b) com entalhe.

Ambos os ensaios foram realizados em um atuador servo hidráulico MTS modelo 204.63, com capacidade de carga de 100 kN. Após o seu término, os corpos de prova fraturados foram examinados, de modo que a altura e a largura de sua seção transversal no local de fratura fossem registradas.

A resistência à flexão de cada corpo de prova é calculada pela equação:

$$
f_{c f}=\frac{F l}{b_{f r} h_{f r}^{2}}
$$

Onde:

$f_{c f}=$ resistência à flexão $(\mathrm{MPa})$;

$F=$ força máxima suportada $(\mathrm{N})$;

$l=$ comprimento de vão $(\mathrm{mm})$;

$b_{f r}$ e $h_{f r}=$ dimensões da seção transversal no local de fratura (mm);

Os valores obtidos por cada corpo de prova foram aproximados ao $0,1 \mathrm{MPa}$ mais próximo.

O ensaio de flexão sem entalhe utilizou o controle do atuador, em uma taxa de deslocamento de $0,1 \mathrm{~mm} / \mathrm{min}$. A deflexão dos corpos de prova foi obtida a partir da média entre os deslocamentos dos transdutores, localizados no meio do vão. A curva representativa do comportamento dos corpos de prova encontra-se na Figura 3-23. Todos os resultados obtidos para esse teste encontram-se na Figura 8-1-b. 


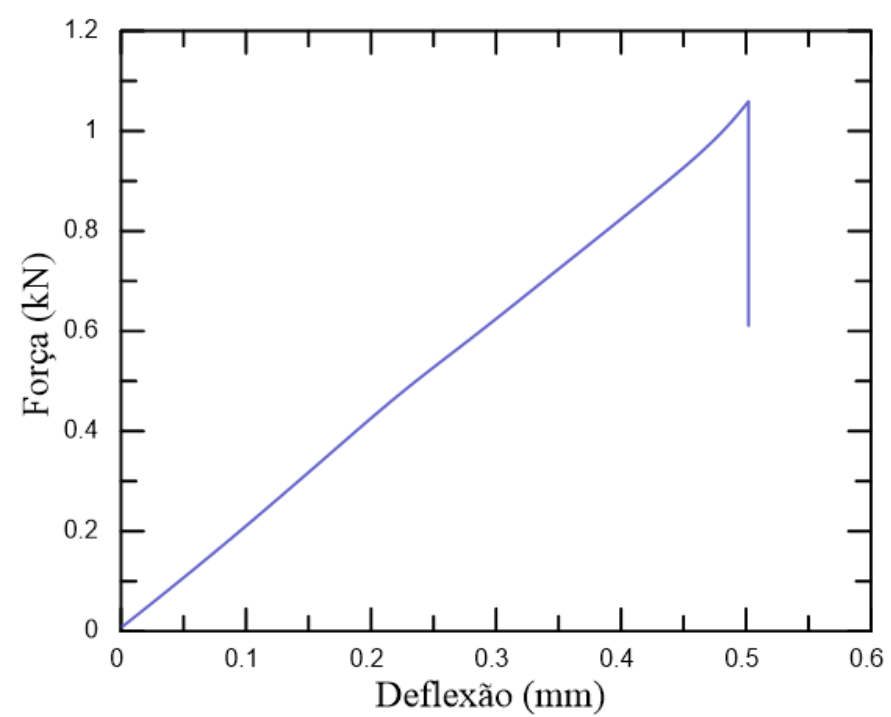

Figura 3-23: Relação entre força aplicada e deflexão dos corpos de prova submetidos à flexão a quatro pontos

Os parâmetros mecânicos do ensaio encontram-se na Tabela 3-9. Além da resistência à flexão, calculada conforme a fórmula mencionada, há a força máxima e sua deflexão correspondente, assim como a tenacidade, calculada a partir da área abaixo da curva força-deflexão. A integral da curva foi obtida por meio do programa OriginPro no ponto de deflexão máxima.

Tabela 3-9: Desempenho mecânico do CCA submetido ao ensaio de flexão a quatro pontos sem entalhe

\begin{tabular}{ccccc}
\hline $\begin{array}{c}\text { Corpo } \\
\text { de } \\
\text { Prova }\end{array}$ & $\begin{array}{c}\text { Força } \\
\text { Máxima } \\
(\mathbf{N})\end{array}$ & $\begin{array}{c}\text { Deflexão } \\
\text { Máxima } \\
(\mathbf{m m})\end{array}$ & $\begin{array}{c}\text { Resistência } \\
\text { à Flexão } \\
\left(\mathbf{N} / \mathbf{m m}^{2}\right)\end{array}$ & $\begin{array}{c}\text { Tenacidade } \\
(\mathbf{N . m})\end{array}$ \\
\hline 1 & 1072 & 0,498 & 0,74 & 0,265 \\
2 & 984 & 0,404 & 0,69 & 0,231 \\
3 & 1062 & 0,531 & 0,74 & 0,267 \\
Média & $\mathbf{1 0 4 0}$ & $\mathbf{0 , 4 7 7}$ & $\mathbf{0 , 7 2}$ & $\mathbf{0 , 2 5 4}$ \\
Desvio & $\mathbf{4 8}$ & $\mathbf{0 , 0 6 6}$ & $\mathbf{0 , 0 3}$ & $\mathbf{0 , 0 2 0}$ \\
Padrão & & & & \\
\hline
\end{tabular}

O valor médio de resistência obtido pelos corpos de prova foi de $0,72 \mathrm{MPa}$, com $0,48 \mathrm{~mm}$ de deflexão. A resistência à flexão habitual do CCA pode alcançar 20 a 40\% da sua resistência à compressão (RILEM, 1993). Conforme calculado no item 3.4.4, a resistência à compressão dos corpos de prova é de 2,3 MPa. Concluise, por consequência, que a resistência esperada pelo material varia entre 0,46-0,92 
MPa. Comparativamente, tem-se que Dey et al. (2015) ensaiaram blocos de CCA sob flexão a três pontos e obtiveram 1,1 MPa de resistência e $0,31 \mathrm{~mm}$ de deflexão no ponto de força máxima. Uddin et al. (2006) obtiveram 0,73 MPa, $900 \mathrm{~N}$ e 0,30 $\mathrm{mm}$ de resistência à flexão a quatro pontos, força máxima e deflexão equivalente, respectivamente. Tais resultados demonstram que o comportamento dos blocos de CCA adequam-se aos valores de referência.

O ensaio de flexão a quatro pontos com entalhe, por sua vez, utilizou o clip gage para o controle da abertura a uma taxa de deslocamento de $0,01 \mathrm{~mm} / \mathrm{min}$. A curva que correlaciona a força aplicada à abertura da entrada do entalhe encontrase na Figura 3-24. O comportamento dos três corpos de prova ensaiados encontrase representado na Figura 8-1-c. A Tabela 3-10 resume os parâmetros do ensaio de flexão com entalhe.

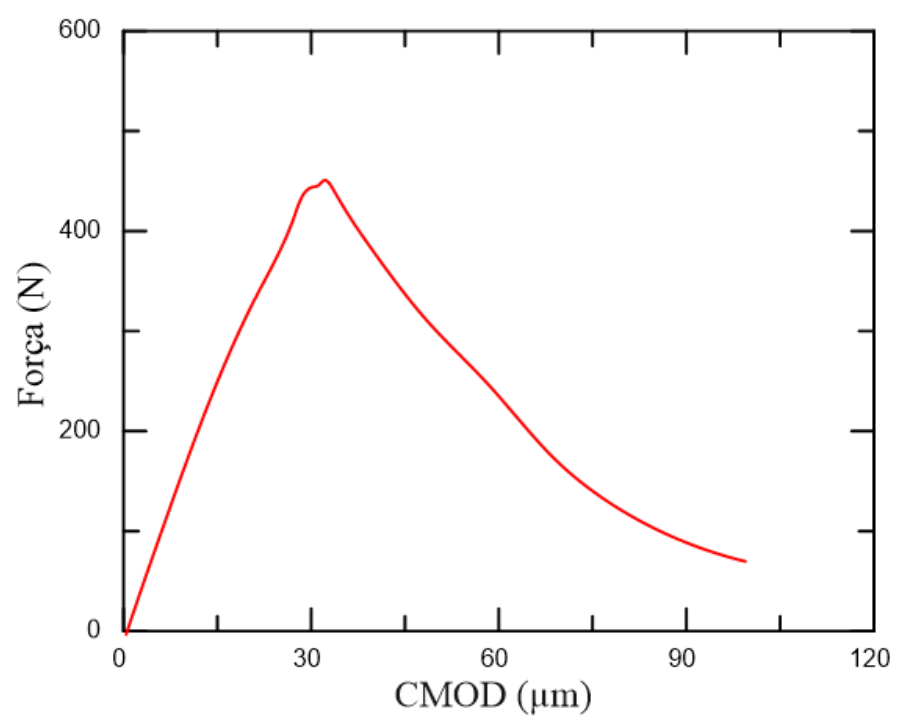

Figura 3-24: Relação entre força aplicada e abertura do entalhe

A força de pico e a deflexão nesse ponto foram registradas, levando-se em consideração os valores obtidos pelos LVDTs do meio do vão. O CMOD máximo representa a abertura do entalhe para a força máxima. A resistência à flexão foi calculada conforme a (Eq. 3-6, descontando-se a altura do entalhe $\left(\mathrm{H}_{\text {total }}-\mathrm{h}_{\text {entalhe }}=\right.$ h) na área da seção transversal.

Em termos de energia, dois parâmetros foram utilizados para a relação força-CMOD: a tenacidade de abertura de fissura foi obtida por meio da área da curva até o ponto de força máxima; a energia de fratura específica, $\mathrm{G}_{\mathrm{f}}$, foi obtida através da área de $\mathrm{P}_{\max }$ até o ponto de ruptura, sendo o resultado dividido pela área 
útil (h x b). A energia de fratura do material é definida como a energia necessária para que uma fissura de área unitária seja formada.

Tabela 3-10: Desempenho mecânico do CCA submetido ao ensaio de flexão com entalhe

\begin{tabular}{ccccccc}
\hline $\begin{array}{c}\text { Corpo } \\
\text { de } \\
\text { Prova }\end{array}$ & $\begin{array}{c}\text { Força } \\
\text { Máxima } \\
(\mathbf{k N})\end{array}$ & $\begin{array}{c}\text { CMOD } \\
\text { Máximo } \\
\mathbf{( m m})\end{array}$ & $\begin{array}{c}\text { Deflexão } \\
\text { Máxima } \\
\mathbf{( m m})\end{array}$ & $\begin{array}{c}\text { Resistência } \\
\text { à Flexão } \\
\left(\mathbf{N} / \mathbf{m m}^{2}\right)\end{array}$ & $\begin{array}{c}\text { Tenacidade } \\
\text { Máxima } \\
\mathbf{( N . m )}\end{array}$ & $\begin{array}{c}\mathbf{G}_{\mathbf{f}} \\
(\mathbf{N} / \mathbf{m})\end{array}$ \\
\hline 1 & 484 & 0,030 & 0,903 & 0,44 & 0,0079 & 4,22 \\
2 & 454 & 0,032 & 0,605 & 0,42 & 0,0081 & 3,70 \\
3 & 469 & 0,028 & 0,927 & 0,43 & 0,0074 & 4,19 \\
Média & $\mathbf{4 6 9}$ & $\mathbf{0 , 0 3 0}$ & $\mathbf{0 , 8 1 2}$ & $\mathbf{0 , 4 3}$ & $\mathbf{0 , 0 0 7 8}$ & $\mathbf{4 , 0 3}$ \\
$\begin{array}{l}\text { Desvio } \\
\text { Padrão }\end{array}$ & $\mathbf{1 5}$ & $\mathbf{0 , 0 0 2}$ & $\mathbf{0 , 1 7 9}$ & $\mathbf{0 , 0 1}$ & $\mathbf{0 , 0 0 0 4}$ & $\mathbf{0 , 2 9}$ \\
\hline
\end{tabular}

Nota-se que, para os corpos de prova com entalhe, a força máxima é consideravelmente reduzida. A partir de um ensaio análogo, Bonakdar et al.(2013) submeteu blocos de CCA de $150 \mathrm{~mm}$ x $150 \mathrm{~mm}$ x $500 \mathrm{~mm}$, com entalhe de $25 \mathrm{~mm}$, à flexão a três pontos. Os corpos de prova alcançaram 0,66 $\mathrm{MPa}$ de resistência à flexão, com 0,051 mm de abertura de entalhe no ponto de força máxima.

Brühwiler et al. (2007) ensaiaram à flexão (configuração de 3 pontos) diversos tipos de CCA, com altura útil (h) igual a 50, 80 e $100 \mathrm{~mm}$, e espessura (b) de 40, 100 e 200 mm. O tipo de CCA leve, com 1,31 GPa de módulo de elasticidade e 2,23 MPa de resistência à compressão, apresentou uma energia de fratura de $\mathrm{Gf}=$ $2,99 \mathrm{~N} / \mathrm{m}$. A energia de fratura do concreto, por outro lado, assume valores típicos de 1, 5 e 7 N/m (RILEM, 1993).

Os blocos de CCA ensaiados apresentaram comportamento similar às pesquisas mencionadas, de forma que a ruptura do material foi caracterizada por uma fissura no meio do vão e completa perda de capacidade de carga. Em geral, tem-se que todos os corpos de prova apresentaram uma fratura brusca, pouco após atingirem a força máxima. O material não apresentou meios de evitar a propagação de fissuras, a qual comprometeu rapidamente a resistência dos corpos de prova. 


\subsection{Conclusões}

A caracterização dos materiais necessários à produção dos painéis sanduíche foi abordada nesse capítulo. A matriz adotada foi desenvolvida para aprimorar a durabilidade do compósito, uma vez que uma parcela do cimento foi substituída por materiais pozolânicos visando a redução do teor de hidróxido de cálcio. No que concerne ao desempenho, a consistência da matriz foi avaliada para que fosse suficientemente fluida para penetrar no reforço unidirecional de fibras. Ensaios de espalhamento demonstraram um valor de $400 \mathrm{~mm}$ no estado fresco e um teor ótimo de superplastificante de 2,5\%. A resistência à compressão de amostras cilíndricas da matriz foi determinada em idades diversas, atingindo 73,8 $( \pm 4,36) \mathrm{MPa}$ em 28 dias.

A fibra de curauá foi caracterizada a partir da correlação entre sua morfologia e performance mecânica. Dez amostras de fibras foram analisadas em um microscópio eletrônico de varredura e suas áreas contabilizadas por meio de um software adequado. A área de seção transversal média das fibras constituiu 0,00531 $\mathrm{mm}^{2}$, sendo utilizada no cálculo de resistência à tração. Os filamentos ensaiados obtiveram uma resistência à tração de $867( \pm 389) \mathrm{MPa}$, módulo de elasticidade de $14,5( \pm 4,6) \mathrm{GPa}$, e deformação máxima de $4,9( \pm 0,5) \%$. A variabilidade do formato e da área de seção transversal das fibras torna o uso de análise de imagens necessário para um cálculo mais preciso da resistência dos filamentos. Ademais, para verificar a capacidade de absorção e dessorção de água pela fibra natural, um ensaio com três filamentos indicou um ganho máximo de $230 \%$ em massa após imersão em água e uma perda de $180 \%$ de massa após o processo de secagem.

$\mathrm{O}$ concreto celular autoclavado foi avaliado não apenas em relação às propriedades mecânicas, mas igualmente em relação à sua estrutura porosa. Após o condicionamento de corpo de provas cúbicas em estufa, sua densidade aparente seca foi determinada como $470 \mathrm{~kg} / \mathrm{m}^{3}$, com teor de umidade de $4,7( \pm 1,9) \%$.

O seu desempenho mecânico foi avaliado por meio de ensaios de compressão e de flexão a quatro pontos em configurações com e sem entalhe. A resistência à compressão média dos corpos de prova foi de $2,3( \pm 0,07) \mathrm{MPa}$. Corpos de prova cilíndricos foram sujeitos à compressão axial para a determinação do seu módulo de elasticidade, cujo valor foi de 1,49 $( \pm 0,01) \mathrm{GPa}$. A resistência à flexão de blocos de $300 \mathrm{~mm}$ x $60 \mathrm{~mm} \times 75 \mathrm{~mm}$ foi de $0,72( \pm 0,03) \mathrm{MPa}$, com deflexão 
máxima de 0,477 $( \pm 0,066) \mathrm{mm}$. Blocos com entalhe de $10 \mathrm{~mm}$ apresentaram resistência de 0,43 $( \pm 0,01) \mathrm{MPa}$, com $0,030( \pm 0,002) \mathrm{mm}$ de abertura máxima de entrada do entalhe e energia de fratura específica de 4,03 $( \pm 0,29) \mathrm{N} / \mathrm{m}$. 


\section{Desempenho Mecânico de Compósitos Cimentícios Reforçados com Fibra de Curauá}

\subsection{Introdução}

O presente capítulo aborda as etapas de produção de compósitos cimentícios reforçados com tecido unidirecional de curauá, compostos por uma matriz com teor reduzido de hidróxido de cálcio, conforme explicitado no capítulo 3. O reforço baseou-se na disposição de três camadas de 6,5 g de fibra de curauá, dispostas de forma longitudinal, perfazendo 7,5\% de fração volumétrica.

Estudos em compósitos reforçados com fibras longas indicam desempenho mecânico satisfatório, particularmente devido à habilidade do tecido em transferir tensões e controlar a abertura de fissuras. A fim de verificar o comportamento dos compósitos em questão, ensaios de tração direta e de flexão a quatro pontos foram executados. Nesse último caso, as deformações foram registradas nas superfícies superior e inferior das amostras, de modo a analisar o desenvolvimento da linha neutra. Ensaios de arrancamento (pull-out) foram realizados para a avaliação da aderência entre fibra e matriz.

\subsection{Procedimento Experimental}

\subsubsection{Processo de Fabricação dos Compósitos}

Os compósitos utilizados nesse trabalho são reforçados com camadas longas unidirecionais de fibra de curauá. Os feixes de fibras, conforme descrito no item 3.3.1, foram submetidos a um processo de limpeza e de separação dos filamentos antes de sua aplicação na argamassa. Os compósitos foram produzidos com $60 \mathrm{~mm}$ de largura e $10 \mathrm{~mm}$ de espessura, mas com variações em seu comprimento, conforme finalidade: para ensaios de tração, corpos de prova de $500 \mathrm{~mm}$ de comprimento, reforçados com camadas de fibra pesando de 6-6,5 g cada; para ensaios de flexão, $350 \mathrm{~mm}$ e fibras com 4,2-5 g; para ensaios de pull-out, $150 \mathrm{~mm}$ de comprimento. 
Cada corpo de prova foi produzido com três camadas de tecido, intercaladas por quatro camadas de matriz, como ilustrado na Figura 4-1. Excepcionalmente para os testes de pull-out, foram fabricados corpos de prova com apenas uma camada de fibras, com $2 \mathrm{~mm}$ de espessura, intercalada por 2 camadas de $4 \mathrm{~mm}$ de matriz cada, mantendo-se a espessura de $10 \mathrm{~mm}$ do compósito. Considerando o número padrão de camadas de reforço, a fração volumétrica dos compósitos resultantes foi de $7,5 \%$.

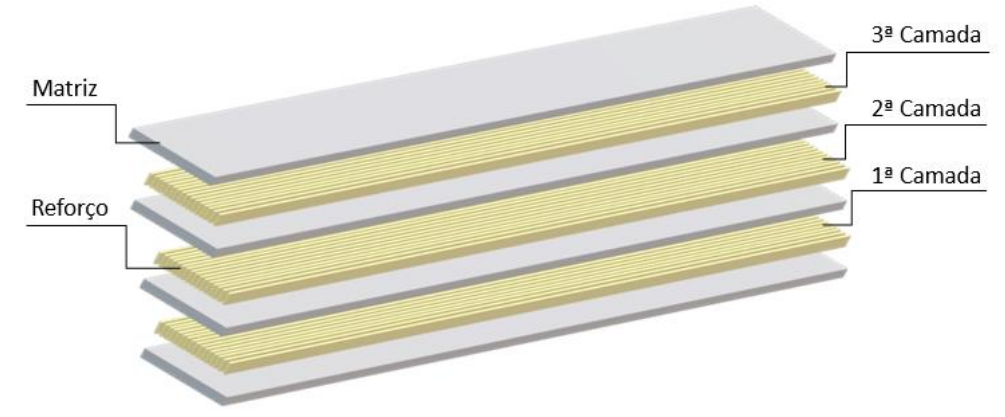

Figura 4-1: Imagem ilustrativa da estrutura do compósito: três camadas de reforço de fibras, indicadas em ordem de disposição, intercaladas por camadas de matriz

Fôrmas de metal de $500 \mathrm{~mm}$ de comprimento útil e $10 \mathrm{~mm}$ de espessura foram utilizadas para a moldagem dos corpos de prova, como demonstrado na Figura 4-2. Para evitar que o contato direto entre a fôrma e o compósito gerasse irregularidades na matriz no processo eventual de desmoldagem, utilizou-se papel contact em toda a sua superfície, além de uma fina camada de desmoldante antes da deposição da argamassa.

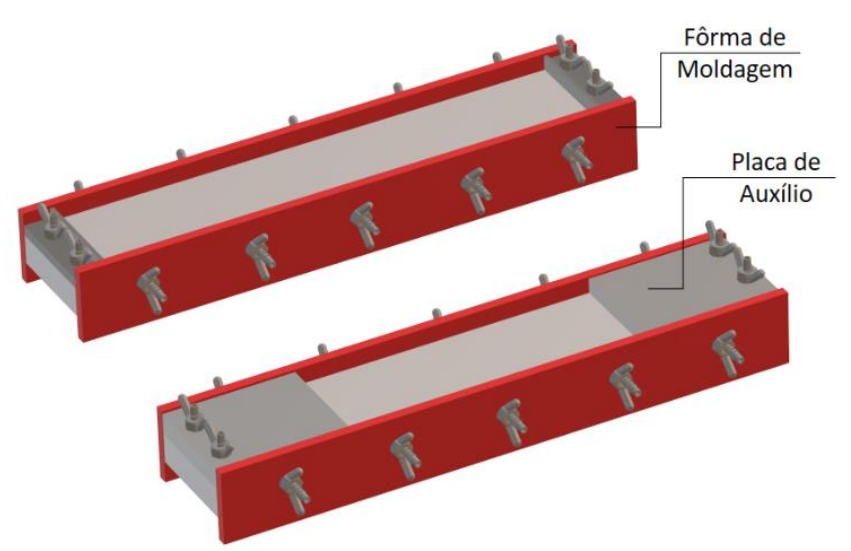

Figura 4-2: Moldes utilizados para a fabricação dos compósitos. Placas de alumínio, cortadas sob medida, foram utilizadas para reduzir o comprimento dos compósitos, quando necessário 
Placas de alumínio auxiliares foram utilizadas para a redução do comprimento dos compósitos de flexão e de pull-out. Nesse último caso, 2 placas de $100 \mathrm{~mm}$ x $60 \mathrm{~mm}$ x $4 \mathrm{~mm}$ (comprimento $\mathrm{x}$ largura $\mathrm{x}$ espessura) foram utilizadas nas extremidades das fôrmas, de modo que os compósitos finais detivessem um comprimento de $300 \mathrm{~mm}$ e uma camada de reforço de $2 \mathrm{~mm}$ de espessura, disposta no centro da matriz, como demonstra a Figura 4-3-c.

As fibras passaram por um processo de preparação prévio à moldagem: primeiramente, foram penteadas, cortadas nas dimensões adequadas e devidamente pesadas. Em seguida, os feixes foram submersos por 2 horas, de forma a assumirem estado saturado, evitando possíveis variações volumétricas quando inseridos na matriz. Ademais, a saturação das fibras preveniria uma possível absorção da água da matriz, desequilibrando sua relação água/cimento. Uma vez retirada da água, cada camada de fibra foi penteada novamente para garantir o alinhamento do reforço na matriz. Entrementes, a matriz foi produzida de acordo com o item 3.2.2.

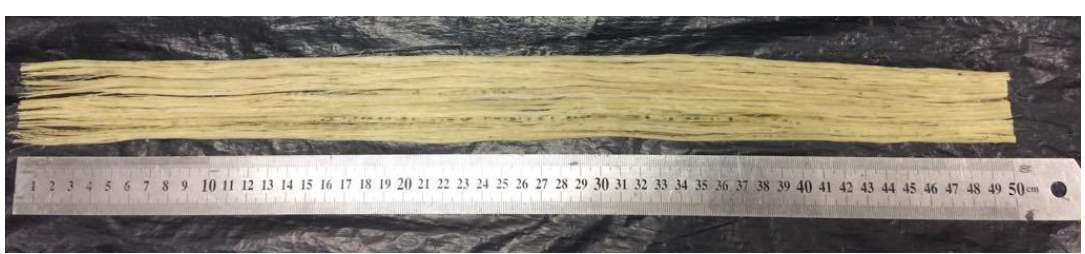

a)

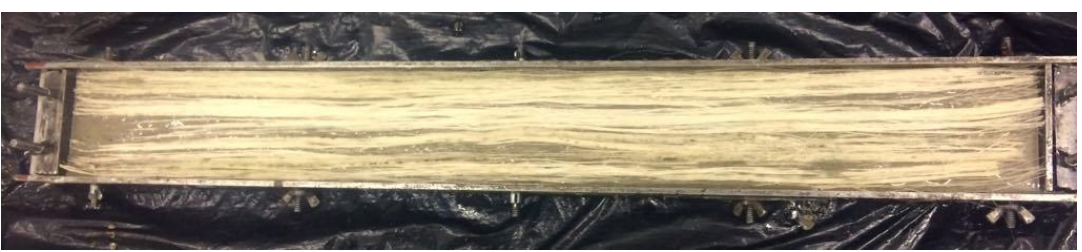

b)
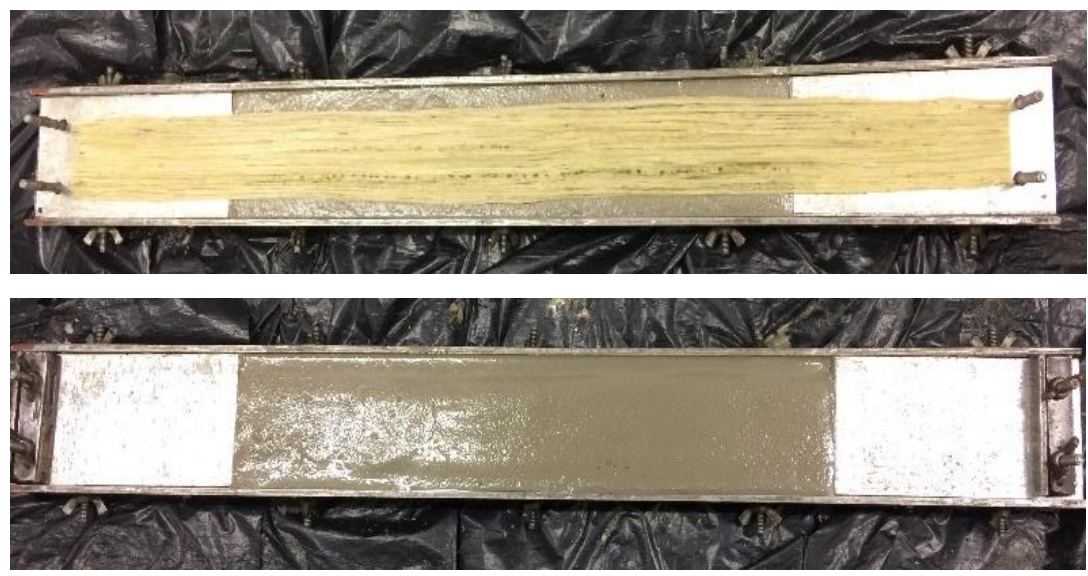

c)

Figura 4-3: Processo de moldagem dos compósitos: a) camada de fibra saturada, penteada e medida; b) disposição do tecido na matriz (dimensões para ensaio de tração); c) fabricação dos corpos de prova de de pullout através da disposição da única camada de fibra, centralizada entre duas camadas de matriz de $4 \mathrm{~mm}$ de espessura cada 
Imediatamente após a moldagem, as amostras foram cobertas por plástico filme em suas respectivas fôrmas com a finalidade de evitar possíveis fissurações por troca de umidade com o meio. Após um período mínimo de 24 horas, os corpos de prova foram desmoldados e curados em câmara úmida.

\subsubsection{Interface Matriz-Fibras}

A interface entre fibra e matriz é um componente de considerável importância no desempenho de um compósito, pois está associada à aderência entre os elementos e a capacidade correlacionada de transmissão de tensões. Há inúmeros fatores que influenciam a aderência fibra-matriz, como a morfologia da fibra (tipo, diâmetro, entre outros), fração volumétrica e orientação em relação à aplicação de carga (BENTUR; MINDESS, 1990).

Particularmente no caso de reforço contínuo, a geometria da malha, o tipo de tecido, o comprimento embutido, a mistura utilizada, o tempo de cura e os métodos de processamento são possíveis causas de variações nos valores de arrancamento (PELED; BENTUR, 2000; SILVA et al., 2011; SUEKI et al., 2007). Para avaliar tal propriedade, ensaios de arrancamento (pull-out) do tecido foram executados em oito amostras, tendo-se o propósito de obter uma relação entre força de arrancamento e deslocamento do reforço.

\subsubsection{Pull-out do Tecido}

Ensaios de arrancamento do tecido de curauá foram executados em amostras produzidas de acordo com o item 4.2.1. Cada placa de $300 \mathrm{~mm}$ de comprimento foi cortada, após a cura de 28 dias, em corpos de prova $150 \mathrm{~mm}$ x $60 \mathrm{~mm}$ x $10 \mathrm{~mm}$, como indicado na Figura 4-4. A camada unidirecional de fibras deteve comprimento de embutimento de $150 \mathrm{~mm}$ e aproximadamente $100 \mathrm{~mm}$ de comprimento livre, correspondente à parcela de tecido excedente.

Para o ensaio, os corpos de prova foram testados em uma máquina MTS 810, com capacidade de carga de $250 \mathrm{kN}$, a partir de uma taxa de deslocamento de $1 \mathrm{~mm} / \mathrm{min}$. O aparato experimental, indicado na Figura 4-5, consistiu no uso de duas placas de aço para a fixação do corpo de prova, unidas por parafusos submetidos a um torque de 8 N.mm. A camada de tecido excedente foi dividida por componentes diversos de fixação: uma dupla de cantoneiras de alumínio, localizada na área inferior do tecido (imediatamente acima das placas de aço), e duas chapas metálicas espessas, localizadas na área superior. 


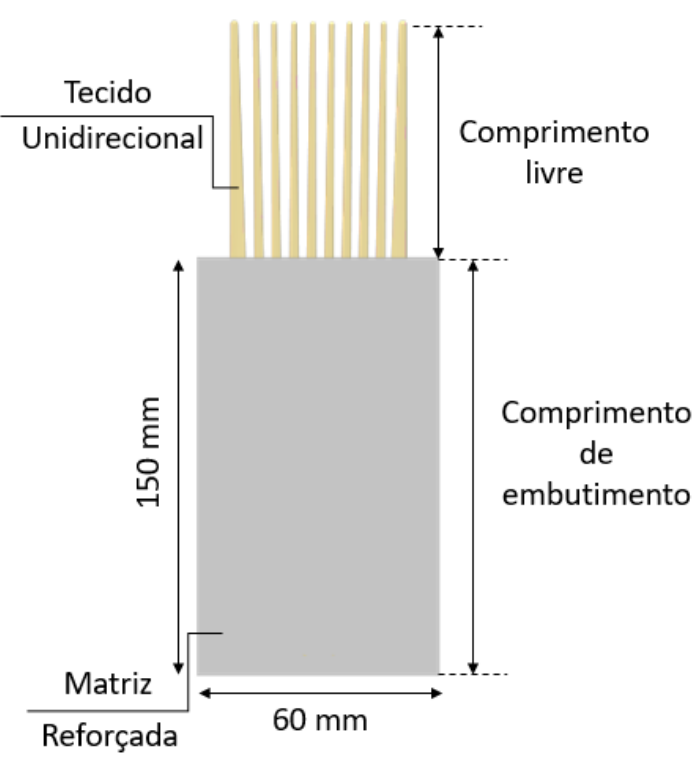

a)

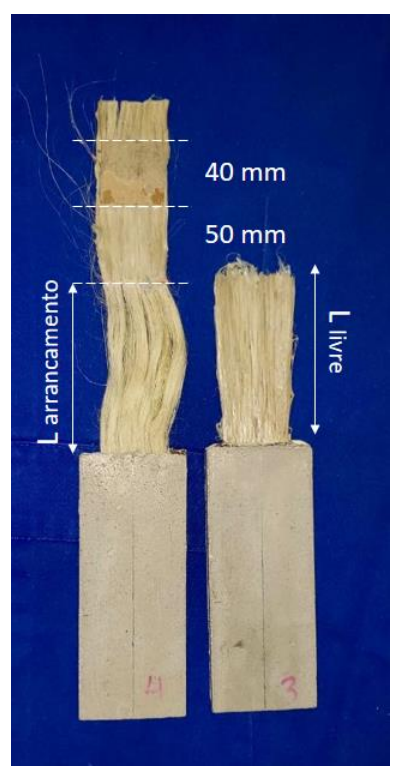

b)

Figura 4-4: Corpo de prova para ensaio de pull-out: a) ilustração dos elementos e dimensões dos corpos de prova; b) corpos de provas antes e após o ensaio, onde se destacam o comprimento livre (L livre), dividido em áreas superior e inferior, e o comprimento arrancado da matriz (L arrancamento). $\mathrm{O}$ uso de cola no tecido atuou como meio de homogeneização da área de contato das fibras

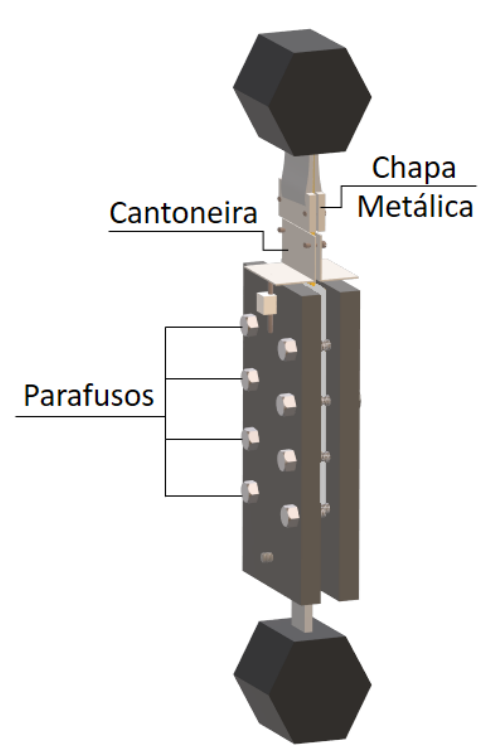

a)

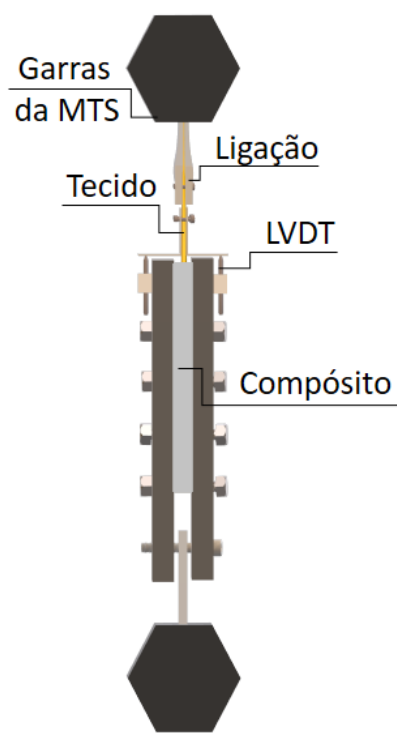

b)

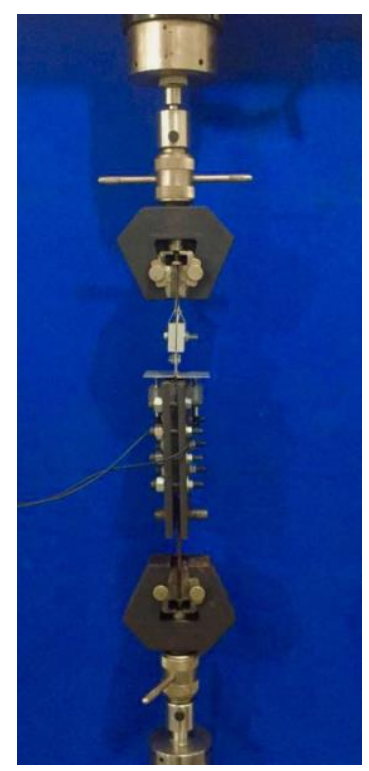

c)

Figura 4-5: Aparato experimental de pull-out: a) ilustração 3D dos elementos do setup; b) vista lateral do aparato, com distinção entre o compósito restrito entre placas de aço e o tecido excedente comprimido entre as cantoneiras e chapas metálicas; c) visão geral do equipamento durante o ensaio

As cantoneiras atuaram como apoio de dois LVDTs de $10 \mathrm{~mm}$ de curso, os quais mediram o deslocamento do tecido durante o processo de seu arrancamento da matriz. As chapas metálicas, por sua vez, comprimiram a parte superior do tecido, de forma a exercer 
suficiente atrito em sua superfície para que a força de tração pudesse ser aplicada sem o desprendimento ou deslizamento das fibras.

Adicionalmente, para unificar a área livre do tecido, utilizou-se cola branca em sua superfície horas antes do ensaio, a fim de que as fibras não se dispersassem durante o teste e a superfície de contato fosse mais homogênea.

\subsubsection{Comportamento Mecânico}

A avaliação do comportamento mecânico de um compósito requer a execução de ensaios que registrem a sua capacidade de suportar tensões e controlar a abertura de múltiplas fissuras. Assim, ensaios de tração direta e de flexão a quatro pontos foram realizados para a obtenção de informações relativas à resistência e à deformação do material sob diferentes tipos de esforços. Os mecanismos de fissuração e ruptura foram registrados e zonas de carregamento identificadas.

\subsubsection{Tração}

Os ensaios de tração direta foram executados em uma máquina de ensaios universais MTS modelo 311, com capacidade de carga de $1000 \mathrm{kN}$. Oito corpos de prova de dimensões $500 \mathrm{~mm}$ x $60 \mathrm{~mm}$ x $10 \mathrm{~mm}$ foram testados aos 28 dias de idade, a uma taxa de deslocamento de 0,1 $\mathrm{mm} / \mathrm{min}$.

As extremidades dos corpos de prova foram acopladas a placas de aço e presas às garras hidráulicas da MTS para a execução do ensaio, como ilustrado na Figura 4-6-c. Devido à irregularidade da superfície dos compósitos, as áreas de extremidade dos corpos de prova foram cobertas por uma camada de massa plástica, de maneira a não gerar interferências nas placas de aço. Para cada parafuso dessas últimas, aplicou-se um torque de 8 N.mm, com o auxílio de um torquímetro, para a fixação dos corpos de prova.

O deslocamento vertical dos corpos de prova foi registrado através de dois transdutores Gefran de $100 \mathrm{~mm}$ de curso, dispostos entre duas estruturas de suporte acopladas às extremidades visíveis do corpo de prova. O comprimento livre das amostras $\left(\mathrm{L}_{0}\right)$ foi medido para cada amostra individualmente, estendendo-se entre as faces superiores dos suportes dos transdutores, como demonstrado na Figura 4-6-a. Em média, o comprimento livre dos corpos de prova foi de $200 \mathrm{~mm}$, com variações. 


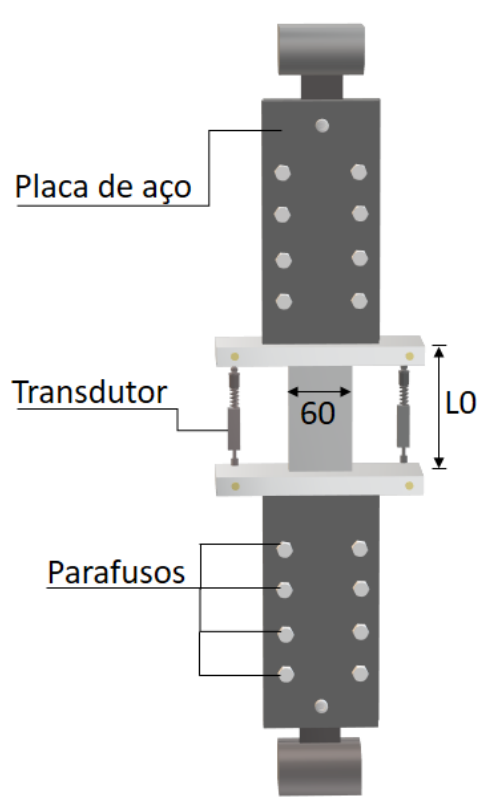

a)

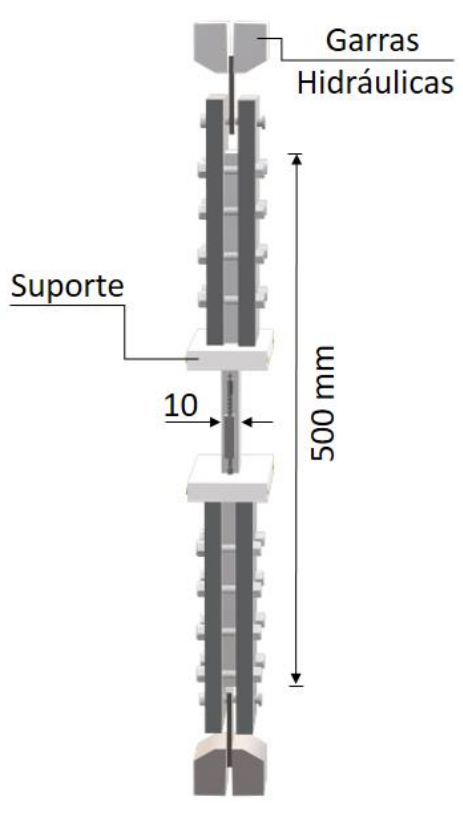

b)

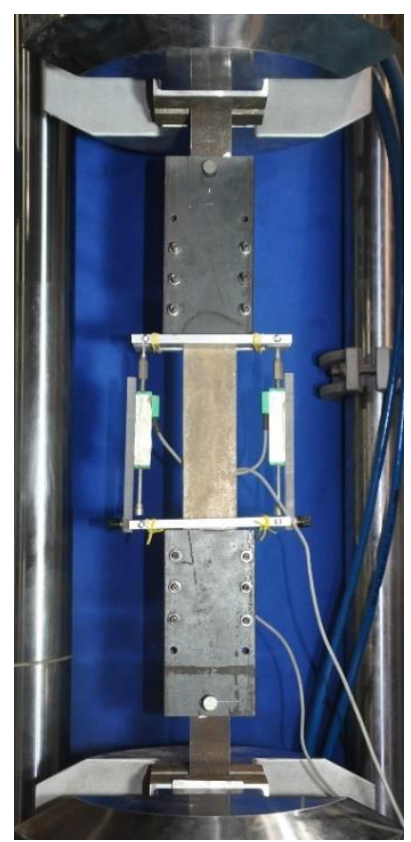

c)

Figura 4-6: Ensaio de tração direta dos compósitos: a) vista frontal dos componentes do setup; b) vista lateral, com detalhe para a espessura dos compósitos; c) arranjo experimental utilizado

\subsubsection{Flexão}

A norma ASTM C1341 (2013) foi utilizada para obter e avaliar as propriedades dos compósitos sujeitos à flexão. Os corpos de prova foram ensaiados sob a configuração de 4 pontos, com espaçamento de 1/3 do vão entre os pontos de aplicação de força, como ilustrado na Figura 4-7-a. Uma vez que o ensaio de flexão a 4 pontos submete uma porção maior dos corpos de prova aos esforços máximos de tração e de compressão, trata-se de uma alternativa preferível à configuração de 3 pontos, segundo recomendação da norma.

Oito corpos de prova de dimensões $350 \mathrm{~mm}$ x $60 \mathrm{~mm}$ x $10 \mathrm{~mm}$ foram testados aos 28 dias em uma máquina de ensaios universais MTS modelo 810, com capacidade de 500 kN. Uma célula de carga de 2,5 $\mathrm{kN}$ foi acoplada ao equipamento para uma leitura mais precisa dos dados de ensaio. O deslocamento vertical dos corpos de prova no meio do vão foi avaliado por dois transdutores Gefran de $50 \mathrm{~mm}$, dispostos em uma placa de metal fina situada na superfície superior do compósito, conforme a Figura 4-7-b.

Os transdutores foram posicionados de maneira invertida por conveniência dessa posição no setup. As deformações associadas aos esforços de compressão e tração foram medidas por meio de dois strain gages dispostos no eixo central superior e inferior de cada 
corpo de prova. Os ensaios foram realizados a uma taxa de $1 \mathrm{~mm} / \mathrm{min}$ por controle de deslocamento.

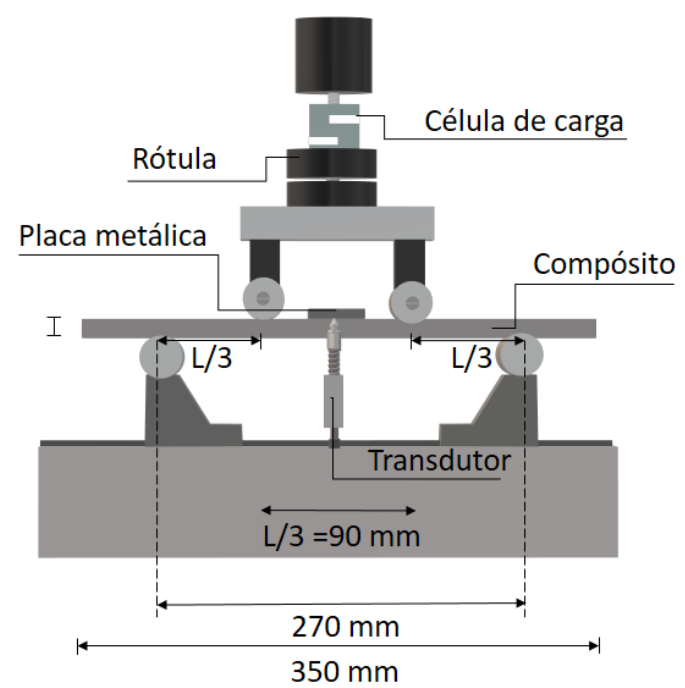

a)

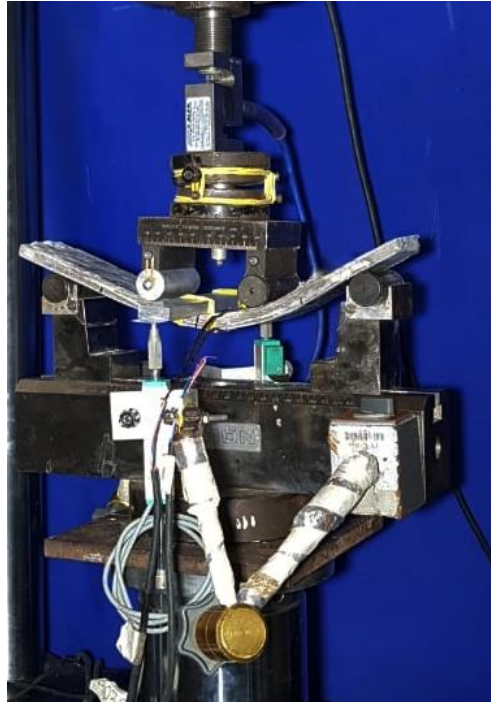

b)

Figura 4-7: Ensaio de flexão a quatro pontos: a) ilustração dos elementos de ensaio e suas respectivas dimensões; b) compósito flexionado durante o teste

\subsection{Resultados e Discussões}

O comportamento mecânico típico dos compósitos é demonstrado e discutido nessa seção para cada ensaio realizado: pull-out do tecido, tração direta e flexão a quatro pontos dos compósitos. A força máxima, capacidade de deflexão ou deformação, tenacidade, rigidez e modo de ruptura foram registrados para cada teste, levando-se em conta os seus valores médios e respectivos desvios padrão.

\subsubsection{Ensaio de Pull-out do Tecido}

A eficiência da adesão entre fibra e matriz, avaliada por ensaios de arrancamento, está diretamente associada ao mecanismo de transferência de tensões entre ambos os elementos. $\mathrm{O}$ comportamento típico dos corpos de prova está expresso na Figura 4-8, a qual relaciona a força de arrancamento $(\mathrm{N})$ com o deslocamento do tecido $(\mathrm{mm})$ durante o processo. As curvas dos outros corpos de prova ensaiados encontram-se na Figura 8-2-b. A média dos valores de força máxima de arrancamento e deslocamento equivalente, tal como os desvios padrão correspondentes, encontram-se na Tabela 4-1. 


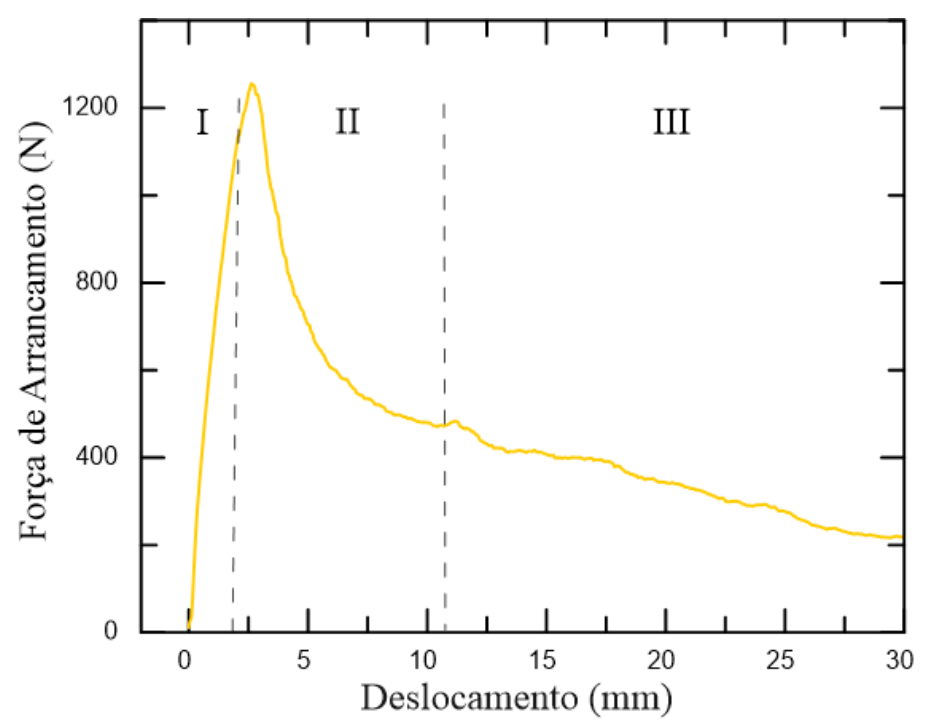

Figura 4-8: Curva típica da força de pull-out pelo deslocamento do tecido, dividida em zonas de acordo com o seu padrão de comportamento

Tabela 4-1: Resumo dos resultados obtidos a partir dos ensaios de pull-out do tecido dos compósitos

\begin{tabular}{cc}
\hline $\begin{array}{c}\text { Força Máxima de Arrancamento } \\
(\mathbf{N})\end{array}$ & $\begin{array}{c}\text { Deslocamento em } \mathbf{P}_{\max } \\
(\mathbf{m m})\end{array}$ \\
\hline $1327( \pm 212)$ & $3,28( \pm 0,52)$ \\
\hline
\end{tabular}

Ao analisar os corpos de prova ensaiados e compará-los ao modelo de Sueki et al. (2007) para compósitos cimentícios reforçados com fibras, é possível notar regiões comuns a todas os corpos de prova, distinguíveis por padrões de comportamento bem definidos. Durante a fase inicial, nota-se um aumento considerável da carga quando fibra e matriz se comportam linearmente - indicativo de que há uma ligação ideal entre a pasta de cimento e o reforço. A região elástico-linear é delimitada pelo fim da zona I, a partir da qual inicia-se um comportamento não-linear, anterior ao alcance da força máxima de arrancamento.

A zona II é caracterizada pelo início do descolamento do tecido e de sua propagação ao longo da matriz. A força máxima de arrancamento ocorre em condições parciais de descolamento e representa o comprimento crítico desse processo. Após atingi-lo, há uma queda progressiva de capacidade de carga e rigidez, notável no pós-pico. O término da zona II é marcado por uma diminuição do deslocamento. Posteriormente, inicia-se a resposta dinâmica do reforço, zona III, quando o descolamento do tecido já ocorreu em sua totalidade e o processo de deslizamento o procede. Trata-se de uma região onde a camada de tecido é de fato arrancada progressivamente de sua matriz, levando a uma diminuição da carga e aumento do deslocamento. 
Em geral, a aderência entre tecido e matriz cimentícia é distinta de outros tipos de reforço, uma vez que, devido à sua seção não homogênea (composta por cordões), apenas os filamentos externos estão em contato direto com a matriz, ao passo que os internos não detêm plena ancoragem (FIDELIS et al., 2016). Há estudos que analisaram o comportamento de adesão para esse caso: Peled e Mobasher (2007) verificaram a resposta mecânica de quatro tipos de tecido em matrizes cimentícias, dentre os quais os tecidos de polipropileno e de vidro alcançaram força máxima de arrancamento de $174 \mathrm{~N}$ e $184 \mathrm{~N}$, respectivamente, para $12,7 \mathrm{~mm}$ de comprimento embutido. Através de uma pesquisa similar, Sueki et al. (2007) obtiveram $144 \mathrm{~N}$ de força de pullout para um tecido de PVA com 7,6 mm de comprimento na matriz.

Nota-se que, para uma dada matriz e seu reforço, há uma relação crescente entre a força máxima de pull-out e o comprimento embutido. Assim, tendo-se em vista que os compósitos analisados possuem uma parcela considerável de seus filamentos ancorados na matriz, e que essa é suficientemente fluida para penetrar na camada unidirecional de fibras de curauá, os valores de força de arrancamento acima de $1 \mathrm{kN}$ demonstram aderência satisfatória entre fibramatriz.

\subsubsection{Ensaio de Tração Direta}

O comportamento de tensão-deformação típico dos compósitos reforçados por longas fibras de curauá, submetidos a ensaios de tração direta, é demonstrado na Figura 4-9.

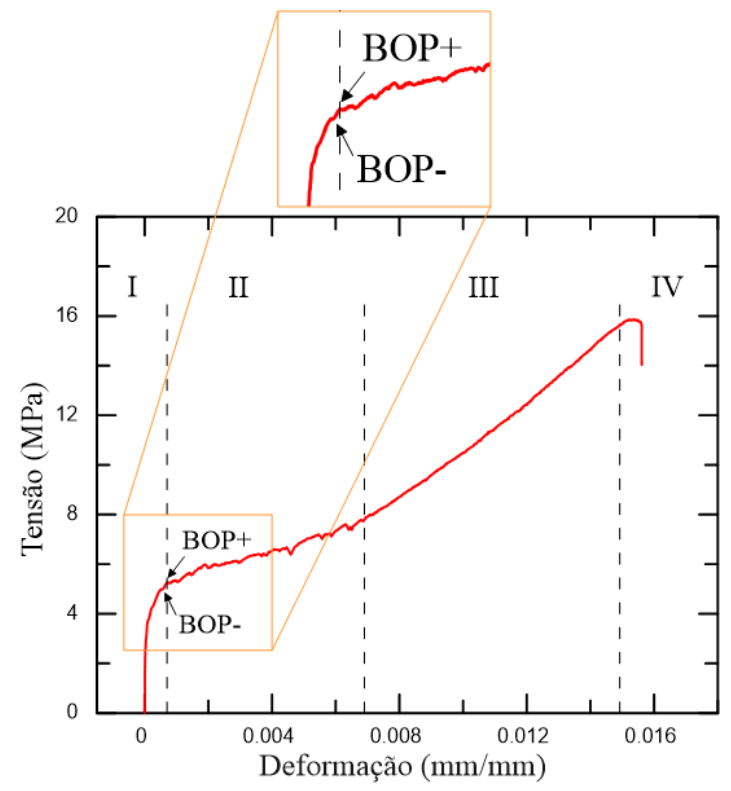

Figura 4-9: Comportamento típico do compósito submetido a ensaios de tração direta e suas respectivas zonas indicativas de seus estágios de fissuração 
O cálculo da tensão é feito por meio da razão entre a força aplicada e a área transversal da amostra. Uma vez que a espessura dos corpos de prova depende da moldagem e pode gerar variações, as seções transversais foram medidas para cada elemento. As deformações, por outro lado, foram calculadas pela razão $\Delta l / \mathrm{L}_{0}$, onde $\Delta l$ representa a média dos deslocamentos obtidos pelos transdutores e $\mathrm{L}_{0}$ o comprimento livre.

O mecanismo de fissuração pode ser dividido em zonas, delimitadas pelo padrão de resposta do compósito em cada região (BALEY, 2002; MOBASHER; PAHILAJANI; PELED, 2006; SILVA; MOBASHER;FILHO, 2009b; YAO et al., 2015). A zona I caracteriza-se como a região elástico-linear, onde se mantém o comportamento linear de ambas matriz e fibras. Nesse caso, tal região é governada majoritariamente pela matriz, tendo-se em vista a baixa fração volumétrica das fibras nos compósitos desenvolvidos. Em seguida, tem-se início o processo de fissuração da matriz, demarcado pelo bend over point, BOP. O ponto de BOPdemarca a tensão onde a primeira fissura na matriz é formada, ao passo que o BOP+ indica a completa formação da fissura na matriz - delimitando o final da zona I.

A zona II engloba a formação e a propagação de fissuras distribuídas, decorrentes do comportamento de múltipla fissuração, característico de compósitos com reforço contínuo. Tal processo indica que, a partir do aparecimento de tensões adicionais, as camadas de fibras longitudinais são capazes de realizar ligações entre as fissuras, transferir as tensões para a matriz e manter a capacidade de carga do compósito. Trata-se, portanto, de uma zona dependente da aderência entre fibra-matriz, a qual influencia o desempenho do reforço.

Ao longo dessa zona, o espaçamento entre as fissuras tende a diminuir de maneira substancial, perdendo-se parte da rigidez do compósito no processo. A estabilização das fissuras ocorre apenas no final da zona II, onde se adquire a saturação do espaçamento das mesmas. Assim, novas fissuras não são formadas, mas as já existentes tornam-se mais largas. A região III, contudo, é governada pelo comportamento do tecido e apresenta ganhos significativos de rigidez e resistência. Por fim, a zona IV inicia-se ante ao aparecimento de uma nova fissura e descreve a situação pós-pico, demarcando a perda da capacidade de resistência do compósito e sua eventual ruptura.

As propriedades mecânicas dos compósitos ensaiados encontram-se indicadas na Tabela 4-2, juntamente com os seus respectivos valores de desvio padrão. A tensão máxima e a deformação correspondente, a tenacidade medida nos pontos de força máxima, tal como a tensão na primeira fissura e a rigidez das curvas nas zonas II e III estão resumidas nesses resultados. 
Tabela 4-2: Propriedades mecânicas dos compósitos submetidos à tração direta

\begin{tabular}{cccccc}
\hline $\begin{array}{c}\text { Tensão } \\
\text { Máxima } \\
(\mathbf{M P a})\end{array}$ & $\begin{array}{c}\text { Deformação } \\
\text { em } \mathbf{P}_{\max }\end{array}$ & $\begin{array}{c}\text { Tenacidade } \\
(\boldsymbol{\%})\end{array}$ & $\begin{array}{c}\boldsymbol{\sigma} \mathbf{J}) \\
(\mathbf{M P P}+\end{array}$ & $\begin{array}{c}\text { Rigidez } \\
\text { Zona II } \\
(\mathbf{k N} / \mathbf{m m})\end{array}$ & $\begin{array}{c}\text { Rigidez } \\
\text { Zona III } \\
(\mathbf{k N} / \mathbf{m m})\end{array}$ \\
\hline 15,09 & 1,40 & 12,92 & 4,76 & 1,03 & 2,60 \\
$( \pm 1,00)$ & $( \pm 0,08)$ & $( \pm 0,45)$ & $( \pm 0,32)$ & $( \pm 0,27)$ & $( \pm 0,23)$ \\
\hline
\end{tabular}

Tem-se que a tensão e a deformação máximas são representantes da capacidade de carga do corpo de prova, ao passo que a tenacidade é uma propriedade associada à absorção de energia do mesmo. A tensão de primeira fissura, $\sigma_{\mathrm{BOP}+}$, denota a resistência média dos compósitos quando os danos à matriz são iniciados e o desempenho do reforço é requerido para manter a resistência. Trata-se de um valor de referência para as propriedades de interface fibra-matriz e para a subsequente degradação das fibras (KUMARIA; KUMAR; SINGH, 1997).

Os valores obtidos pelos corpos de prova são compatíveis com referências similares da literatura: Silva et al. (2009b) obtiveram $12 \mathrm{MPa}, 1,53 \%$ e 5,10 $\mathrm{MPa}$ de resistência à tração, deformação última e $\sigma_{\mathrm{BOP}+}$, respectivamente, para compósitos reforçados com $10 \%$ de fibras de sisal. Toledo Filho et al. (2009) alcançaram 17,82 MPa de resistência à tração, 6,23 MPa de $\sigma_{\mathrm{BOP}+}$ e $21,70 \mathrm{~kJ} / \mathrm{m}^{2}$ de tenacidade total para compósitos reforçados com fibras longas de sisal e matriz livre de $\mathrm{CH}$. Para compósitos reforçados com 3 camadas alinhadas de juta, sem tratamento, Fidelis (2014) obteve 4,38 MPa de resistência, 3,49\% de deformação última e 2,39 $\mathrm{MPa}$ de $\sigma_{\mathrm{BOP}+}$

Adicionalmente, a avaliação da rigidez dos compósitos durante o ensaio, através da relação entre força $(\mathrm{kN})$ e deflexão $(\mathrm{mm})$, é particularmente necessária, pois indica o comportamento apresentado pelos corpos de provas conforme diferentes elementos de sua constituição são requisitados - quer sejam a matriz, o reforço ou a aderência entre ambos. A região elástica da curva, zona I, representa o módulo de elasticidade do compósito; a rigidez da zona II indica o comportamento dos corpos de provas ante à fissuração da matriz, ao passo que a rigidez da zona III representa a resposta pós-fissuração do compósito.

A rigidez do compósito na zona elástica (zona I) não se encontra indicada na tabela, pois a análise dos resultados apresentou um valor abaixo de $10 \mathrm{GPa}$ - o que não condiz com a literatura, conforme demonstram estudos para compósitos unidirecionais de curauá (DE OLIVEIRA; HELFER; AMICO, 2012; SOUZA, 2017). Isso se deve ao fato de que os corpos de prova apresentaram um acréscimo súbito de tensão nos momentos iniciais do ensaio e, em seguida, um pequeno trecho com rigidez reduzida antes da primeira fratura. Tal trecho, 
destacado na Figura 4-10, indica a redução de rigidez antes do início da zona II, sendo responsável pelo valor inferior ao esperado. Consequentemente, o módulo de elasticidade foi calculado para os corpos de provas sob flexão, como explicitado no item 4.3.3. Todas as curvas de tração e flexão obtidas podem ser encontradas no apêndice A, seção 8.2.

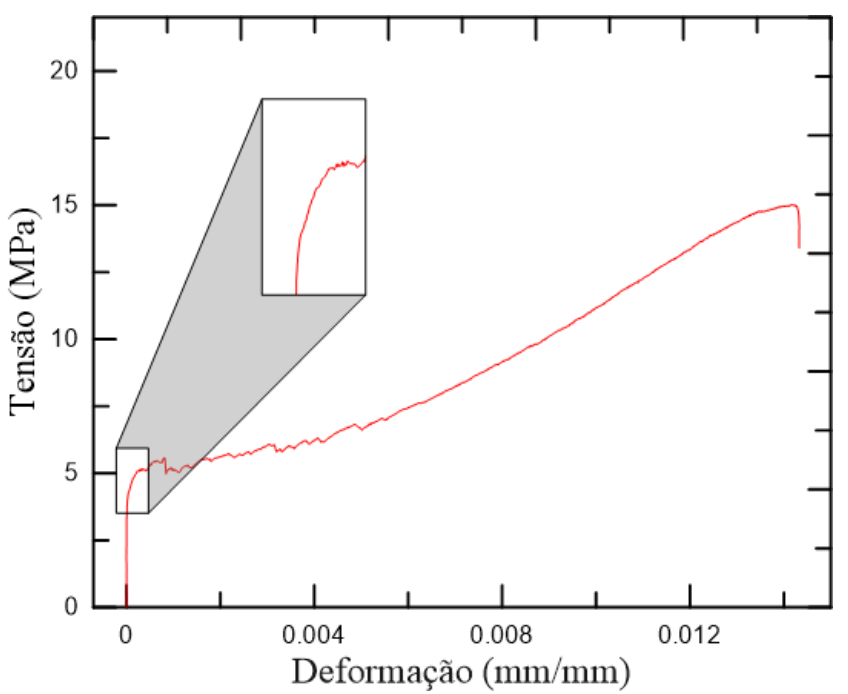

Figura 4-10: Curva tensão vs deformação com detalhe para o trecho de rigidez reduzida anterior à zona II

A rigidez dos compósitos nas zonas II e III foi obtida por meio do coeficiente angular de retas adequadas às regiões das curvas. Nota-se que, durante o processo de múltipla fissuração na zona II, os corpos de prova apresentaram uma média de $1,03 \mathrm{kN} / \mathrm{mm}$, com uma visível perda de rigidez em relação à zona elástico-linear. Esse comportamento decorre da formação de fissuras que transpassam a largura do compósito e reduzem sua capacidade de carga. A zona III, no entanto, demonstrou uma rigidez média de $2,60 \mathrm{kN} / \mathrm{mm}$. Tal resultado demonstra a eficiência do reforço em suportar os esforços e aumentar a rigidez dos corpos de prova, proporcionando um comportamento de strain-hardening.

O padrão de fissuração apresentado pelos corpos de prova encontra-se indicado na Figura 4-11, com o aparecimento de múltiplas fissuras e ocasional delaminação observada nas extremidades das amostras presas às placas de aço. Tem-se que o comportamento final do compósito é um reflexo de processos cumulativos de danos à sua estrutura, seja na forma de fissuração na matriz, descolamento das fibras ou delaminação.

Observou-se, através do processo de moldagem e dos posteriores ensaios, que variações no desempenho dos corpos de prova se deveram à presença de falhas durante sua fabricação - seja na disposição das camadas ou no adensamento inadequado. Não obstante, os compósitos desenvolvidos apresentaram resposta mecânica satisfatória, com múltipla fissuração, pouca 
variação de tensão última (conforme ilustrado na Figura 8-2-c do apêndice A) e ganho de resistência com o aumento da deformação.

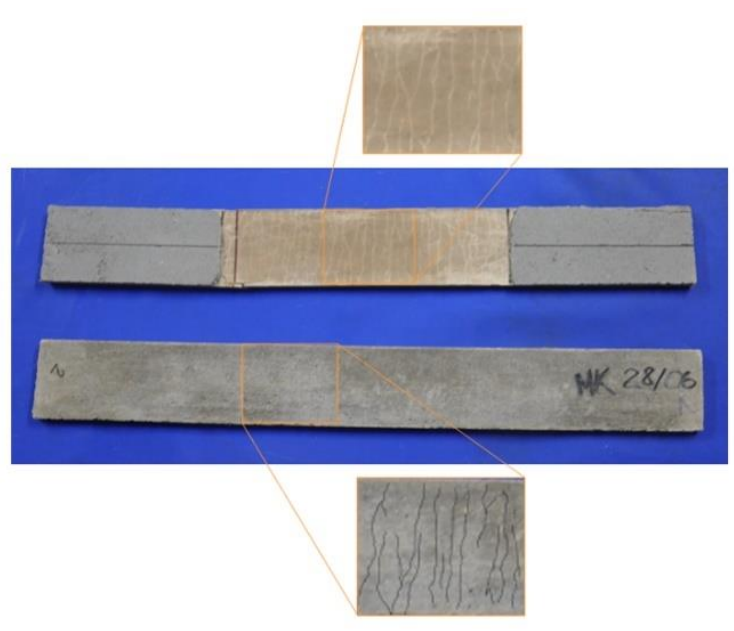

a)

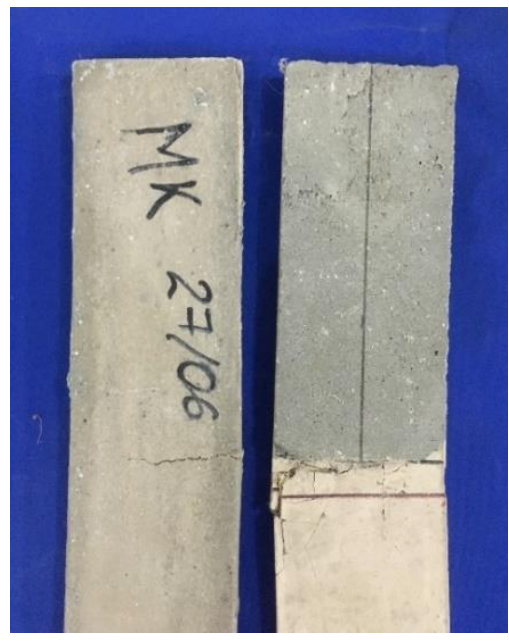

b)

Figura 4-11: Modo de fissuração na tração direta: a) detalhe da formação de múltiplas fissuras na frente e no verso dos corpos de prova ensaiados; b) ruptura e delaminação observados em algumas amostras após o ensaio

\subsubsection{Ensaio de Flexão a Quatro Pontos}

O cálculo das propriedades de flexão dos compósitos é baseado em equações clássicas de vigas, através de hipóteses simplificadoras, nas quais assume-se que o material seja homogêneo, elástico-linear e as seções permaneçam planas após flexão. Os valores de tensão na flexão são calculados a partir da relação:

$$
\sigma=\frac{P L}{b d^{2}}
$$

Onde:

$\sigma=$ tensão a uma dada força $(\mathrm{MPa})$;

$\mathrm{P}=$ força aplicada $(\mathrm{N})$;

$\mathrm{L}=$ comprimento do vão (mm);

$\mathrm{b}=$ largura do corpo de prova $(\mathrm{mm})$;

$\mathrm{d}=$ espessura do corpo de prova $(\mathrm{mm})$; 
A resistência à flexão é equivalente à tensão máxima, sendo calculada por uma fórmula análoga para a força máxima aplicada. A deflexão máxima, por conseguinte, é o valor referente ao ponto de tensão máxima.

Para a caracterização do módulo de elasticidade do compósito, os resultados dos ensaios de flexão foram utilizados em substituição aos de tração, como justificado na seção anterior. O módulo de elasticidade tangente foi, então, obtido a partir do traçado de uma reta tangente à parcela linear do gráfico força-deflexão (isto é, antes do aparecimento das múltiplas fissuras), cuja inclinação é também relacionada ao vão, largura e espessura dos corpos de provas, conforme a fórmula abaixo:

$$
E=0,21 \frac{L^{3} m}{\left(b d^{3}\right)}
$$

Onde:

$\mathrm{E}=$ módulo de elasticidade $(\mathrm{MPa}) ;$

$\mathrm{L}=$ comprimento do vão externo $(\mathrm{mm})$;

$\mathrm{m}=$ inclinação da tangente à reta da região elástica da curva força-deflexão $(\mathrm{N} / \mathrm{mm})$;

$\mathrm{b}=$ largura do corpo de prova $(\mathrm{mm})$;

$\mathrm{d}=$ espessura do corpo de prova $(\mathrm{mm})$;

O comportamento típico dos compósitos submetidos à flexão é melhor representado pela Figura 4-12, a partir da curva de tensão-deflexão. De forma análoga ao ensaio de tração, a resposta mecânica dos compósitos pode ser descrita por diferentes etapas: inicialmente, uma região elástico-linear; em seguida, a formação e multiplicação de fissuras; posterior saturação e abertura progressiva das fissuras já formadas, gerando perda abrupta de resistência. A primeira zona é governada pela matriz, ao passo que a terceira depende essencialmente do desempenho do reforço e de seu processo de intersecção de fissuras até o ponto de ruptura.

Nota-se que todos os corpos de prova apresentaram múltipla fissuração e deflection hardening, demonstrando considerável capacidade de absorção de energia. Para avaliar essa propriedade, a tenacidade dos corpos de prova foi calculada para o ponto de força máxima, considerando-se a área englobada pelo gráfico de força-deflexão. A Tabela 4-3 descreve as propriedades mecânicas resultantes dos ensaios, tal como os seus desvios padrão. 


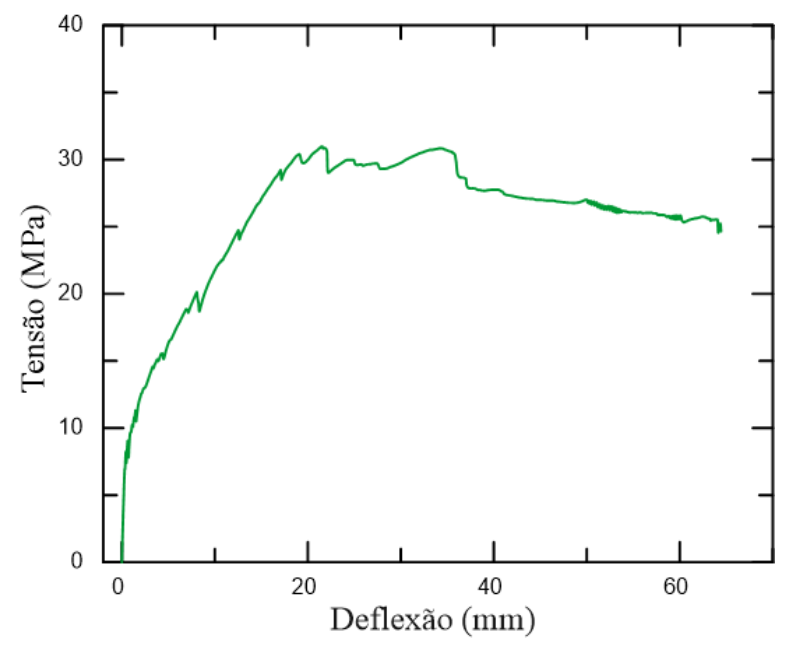

Figura 4-12: Comportamento do compósito sob flexão a quatro pontos, relação tensão vs deflexão

Tabela 4-3: Propriedades mecânicas dos compósitos submetidos à flexão a quatro pontos

\begin{tabular}{cccc}
\hline $\begin{array}{c}\text { Tensão Máxima } \\
(\mathbf{M P a})\end{array}$ & $\begin{array}{c}\text { Deflexão em } \mathbf{P}_{\text {max }} \\
(\mathbf{m m})\end{array}$ & $\begin{array}{c}\text { Tenacidade } \\
(\mathbf{J})\end{array}$ & $\begin{array}{c}\text { Módulo de Elasticidade } \\
(\mathbf{G P a})\end{array}$ \\
\hline $32,16( \pm 5,19)$ & $33,39( \pm 7,36)$ & $13,32( \pm 2,89)$ & $26,88( \pm 16,60)$ \\
\hline
\end{tabular}

O valor médio de resistência à flexão obtido pelo material, tal como sua tenacidade, equipara-se a outros compósitos reforçados com fibras vegetais, como indica a literatura. Compósitos cimentícios reforçados com tecido de sisal, com cinco camadas alinhadas, apresentaram uma resistência à flexão máxima de $25,7 \mathrm{MPa}, 22,13 \mathrm{~kJ} / \mathrm{m}^{2}$ de tenacidade e 29,55 GPa de módulo de elasticidade inicial em seus ensaios (SILVA et al., 2009). Compósitos reforçados com cinco camadas de fibras de curauá, com $6 \%$ de fração volumétrica, obtiveram resistência à flexão de 27,52 MPa e tenacidade de 29,13 kJ/m² (D’ALMEIDA et al., 2009).

O modo de ruptura predominante nos compósitos foi caracterizado por fissuras originadas na região tracionada dos corpos de prova, estendendo-se ao longo da face, usualmente a uma distância de 2,5-5,5 mm do eixo central, conforme indicado na Figura 4-13c. Isso decorre do fato de que, uma vez que o reforço das fibras cobre a direção paralela às suas camadas, o compósito deve recorrer à matriz, elemento mais frágil, para resistir aos esforços transversais.

Alguns corpos de prova igualmente apresentaram um modo de ruptura por tração acompanhada de delaminação, devido à existência de altas tensões interlaminares, gerando fissuras que se originam na interface entre camadas, como demonstrado na Figura 4-13-b. A 
delaminação pode ter ocorrido devido a defeitos originados durante a moldagem, como adensamento insuficiente (inserção de vazios na matriz).

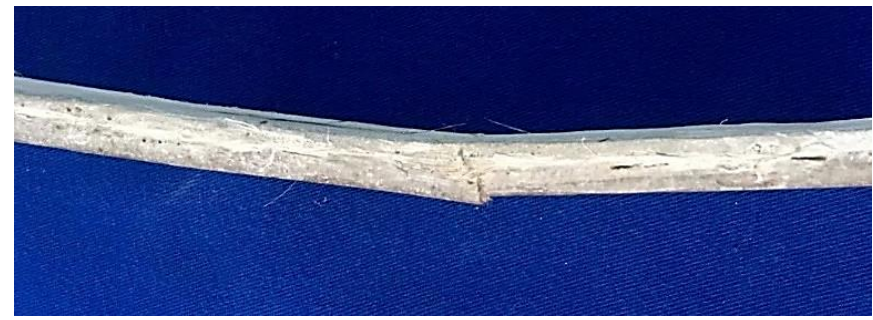

a)

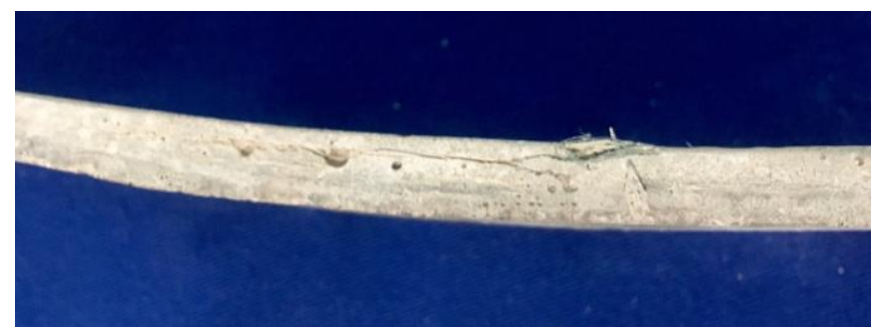

b)

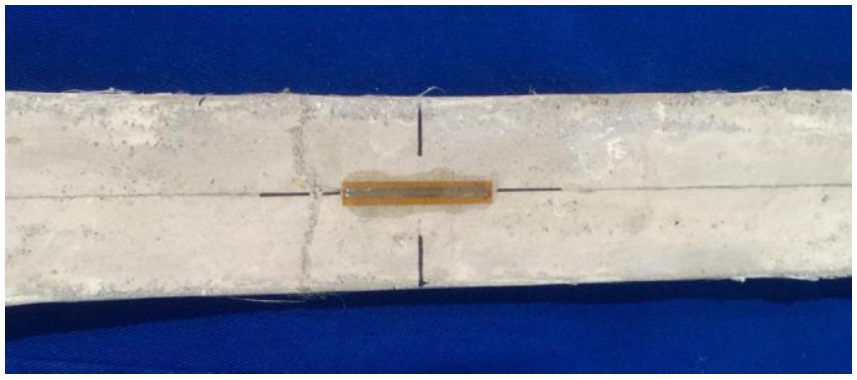

c)

Figura 4-13: Modo de ruptura dos compósitos ensaiados à flexão: a) fissuras de tração originárias na parte inferior do corpo de prova; b) fissuras de tração com delaminação; c) fissuras alargam-se ao longo da seção e levam o compósito à ruptura

Para avaliar outro aspecto das propriedades do material sob flexão, a mudança de posição da linha neutra foi determinada experimentalmente através dos strain-gages acoplados às superfícies superior (área comprimida) e inferior (área tracionada). Assumindo-se que as seções permanecem planas após flexão, o valor variável da linha neutra, normalizado com a espessura do compósito, foi calculado como indicado abaixo:

$$
L N=\frac{y}{d}=\frac{\varepsilon_{\text {sup }}}{\varepsilon_{\text {sup }}+\varepsilon_{\text {inf }}}
$$


Onde:

$\mathrm{LN}=$ linha neutra normalizada em função da distância com relação à face superior;

$\mathrm{y}=$ distância medida do topo do compósito até a linha neutra ( $\mathrm{mm})$;

d = espessura do compósito $(\mathrm{mm})$;

$\varepsilon_{\text {sup }}=$ deformação de compressão, strain-gage superior $(\mathrm{mm} / \mathrm{mm})$;

$\varepsilon_{\text {inf }}=$ deformação de tração, strain-gage inferior $(\mathrm{mm} / \mathrm{mm})$;

Dessa forma, a linha neutra varia entre 0 (face mais comprimida) e 1 (face mais tracionada). A curva que demonstra o comportamento da LN em relação à deformação encontra-se na Figura 4-14:

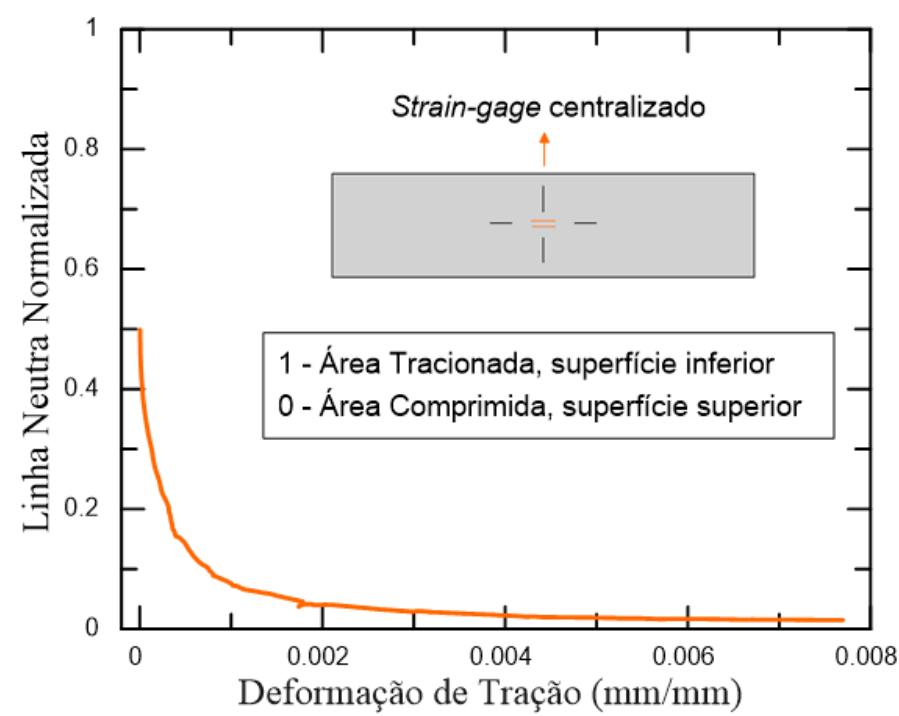

Figura 4-14: Movimento da linha neutra ao longo do ensaio de acordo com o strain-gage inferior

Os oito compósitos ensaiados apresentaram variações de comportamento, com uma tendência principal, na qual a linha neutra apresentou-se na posição centroidal do material, $0,5 \mathrm{~d}$, na região elástica da curva. Após o aparecimento da primeira fissura, as amostras apresentaram mudança da linha neutra a uma posição muito próxima ao 0 , isto é, à superfície superior do compósito e área comprimida. Tal posição da LN indica a existência de fissuras localizadas e a propagação das mesmas com profundidade similar à da primeira fissura. Os strain-gages usualmente perderam a capacidade de registrar as deformações após $0,008 \mathrm{~mm} / \mathrm{mm}$.

Um comportamento similar foi observado por Souza (2017), cujos corpos de prova reforçados com 3 e 5 camadas de fibras alinhadas de curauá apresentaram uma linha neutra próxima a $0,5 \mathrm{~d}$ no início do ensaio. No caso de 3 camadas, os corpos de prova mantiveram sua 
LN próxima ao topo do material durante o processo de deformação; para 5 camadas, a LN mostrou-se menos profunda, mantendo uma posição de $19 \%$ do topo do corpo de prova.

A variação de comportamento entre os diferentes corpos de prova ensaiados pode ter sua origem em inúmeros fatores, como a disposição das camadas de fibra durante a moldagem ou ainda à posição e à cola dos strain-gages nas superfícies do compósito.

\subsection{Conclusões}

A avaliação da interface fibra-matriz e das propriedades mecânicas de compósitos reforçados com três camadas de fibras de curauá foi abordada nesse capítulo. Ensaios de pullout do tecido demonstraram três respostas distintas do compósito: linear, não-linear e dinâmica. Para um comprimento de embutimento de $150 \mathrm{~mm}$, obteve-se uma força média de arrancamento de $1327( \pm 212)$ N, o que demonstra considerável adesão entre fibra e matriz.

Ensaios de tração direta foram executados em oito amostras com $500 \mathrm{~mm}$ de comprimento. Todos os corpos de provas apresentaram comportamento de múltipla fissuração e strain-hardening. Obteve-se uma resistência à tração média de 15,09 $( \pm 1,00)$ MPa e uma tensão de primeira fissura de 4,76 $( \pm 0,32) \mathrm{MPa}$. Quatro zonas principais foram observadas nas curvas de tensão-deformação de acordo com sua característica principal: comportamento elástico-linear de matriz e fibras; fissuração da matriz; saturação e alargamento das fissuras; queda de capacidade de carga e eventual ruptura.

Ensaios de flexão a quatro pontos foram executados em oito corpos de prova de $350 \mathrm{~mm}$ de comprimento. Os testes indicaram uma resistência à flexão de 32,16 $( \pm 5,19) \mathrm{MPa}$ e um módulo de elasticidade de 26,88 $( \pm 16,60) \mathrm{GPa}$ - indicativos de um desempenho mecânico considerável. Strain-gages dispostos nas superfícies dos compósitos permitiram a análise das deformações e da linha neutra. A LN, inicialmente localizada na metade da espessura do compósito, moveu-se para a área superior, indicando fissuras localizadas e ruptura dos compósitos por tração.

Em geral, os compósitos apresentaram resultados satisfatórios, demonstrando aderência adequada entre fibra-matriz, alta resistência à tração e à flexão, e uma grande capacidade de deformação. 


\section{Desempenho Mecânico de Painéis Sanduíche Compósitos}

\subsection{Introdução}

O capítulo a seguir aborda a produção de painéis sanduíche constituídos por compósitos laminados reforçados com fibras e entremeados por um núcleo de CCA. Tem-se que o desempenho de um painel sanduíche está associado à sua capacidade de agir como um compósito - isto é, apresentando interação ideal entre as lâminas e o núcleo -, assim como à sua resistência a diferentes esforços e condições. A partir desse princípio, analisam-se as propriedades mecânicas e de aderência dos corpos de prova através dos seguintes ensaios principais: flexão a quatro pontos com carregamento monotônico e cíclico (carregamentodescarregamento), e aderência (pull-off), respectivamente. A microestrutura da interface foi igualmente avaliada por meio de análise de imagens.

\subsection{Procedimento Experimental}

\subsubsection{Produção dos Painéis Sanduíche}

Os painéis sanduíche são compostos por dois compósitos laminados reforçados com fibra unidirecional de curauá, de $10 \mathrm{~mm}$ de espessura, e um núcleo de concreto celular autoclavado pré-fabricado, de 70 a $75 \mathrm{~mm}$ de espessura. Os corpos de prova foram produzidos a partir da moldagem direta dos compósitos na superfície de blocos de CCA, os quais foram previamente condicionados a um teor de umidade entre 5 e 15\%. Não foram utilizados conectores entre as lâminas e o núcleo ou quaisquer métodos que facilitassem a união lâminasnúcleo, cabendo à interação entre o cimento e a superfície porosa do CCA as condições de aderência do painel. Optou-se, assim, por um sistema mais simples, rápido e sustentável, baseado na escolha de materiais adequados e com potencial de apresentarem uma aderência satisfatória entre si.

Compensados navais, com espessura de $20 \mathrm{~mm}$, foram montados ao redor dos blocos de CCA, de dimensões de $350 \mathrm{~mm}$ x $60 \mathrm{~mm}$ x $70 \mathrm{~mm}$ (comprimento x largura x altura), de maneira 
a permitir que os $10 \mathrm{~mm}$ das superfícies superior e inferior da fôrma fossem utilizados para a moldagem, conforme ilustra a Figura 5-1:

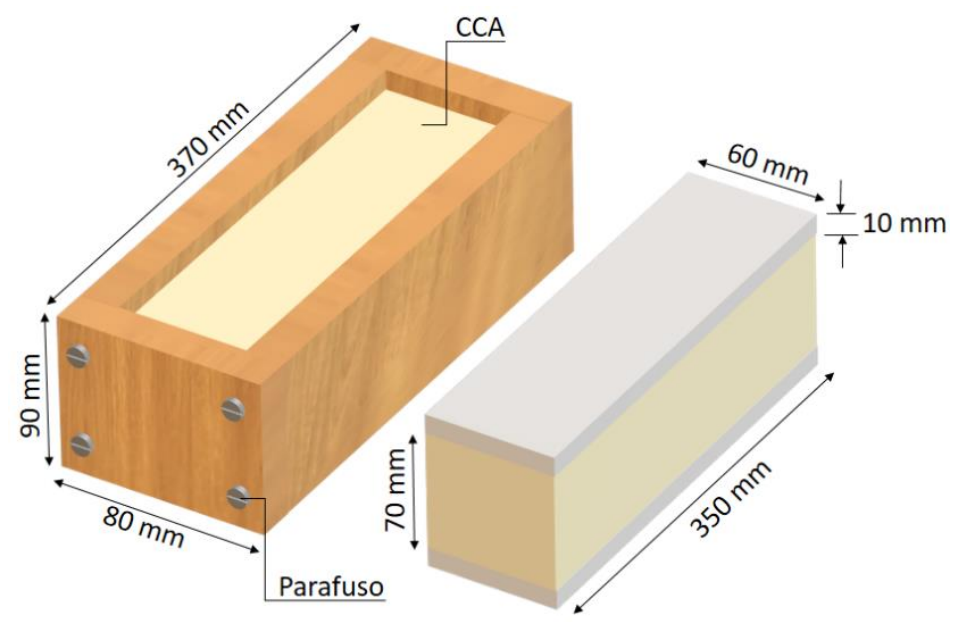

Figura 5-1: Moldagem dos painéis sanduíche: à esquerda, fôrma de madeira montada ao redor do bloco de CCA, centralizado em seu interior antes da produção dos corpo de provas; à direita, painel sanduíche finalizado após a moldagem das placas de compósitos em dias consecutivos

Uma vez que o CCA é um material altamente poroso, a superfície dos blocos foi umedecida imediatamente antes da moldagem, de forma que o material não absorvesse a água da matriz após a disposição da primeira camada de argamassa, como demonstra a Figura 5-2. A superfície interna da fôrma, por sua vez, foi submetida a uma camada de desmoldante apropriado, de modo a evitar danos na matriz após o desmolde.
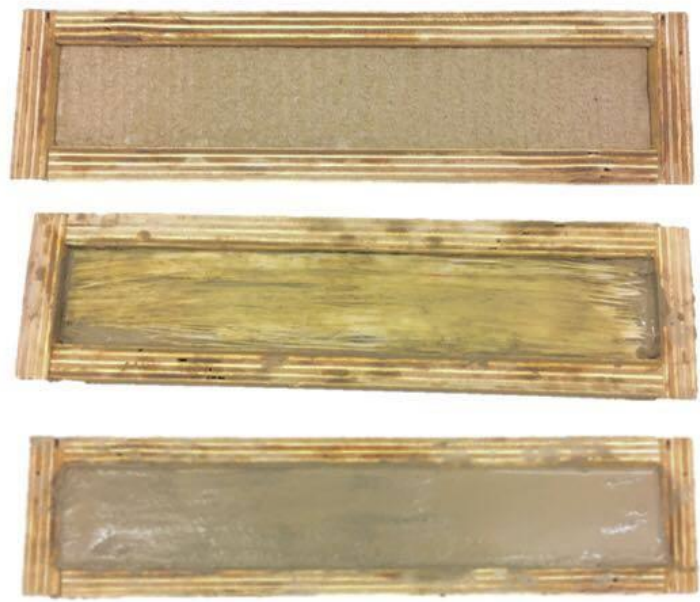

Figura 5-2: Etapas de produção dos compósitos, em ordem: umedecimento da superfície de moldagem do bloco de CCA; disposição da primeira camada de fibras longas alinhadas de curauá sobre a matriz; última camada de matriz do compósito laminar após a disposição de três camadas de tecido como reforço 
O processo de fabricação dos painéis exigiu dois dias de moldagem - o primeiro para a execução do compósito laminar superior e sua cura de 24 horas, e o segundo para a produção da camada inferior. Placas de acrílico, cortadas sob medida, foram posicionadas sobre as placas de compósito após a moldagem, de maneira a evitar a perda de umidade com o meio e exercer pressão sobre os corpos de prova para reforçar a sua aderência. O uso de desmoldante na superfície de contato do acrílico permitiu que o mesmo não aderisse à argamassa nesse processo.

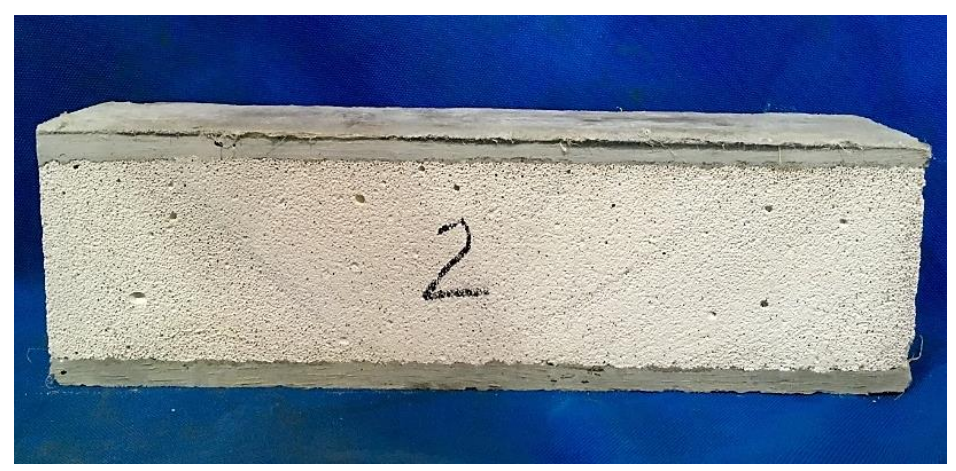

Figura 5-3: Painel sanduíche após o processo de moldagem

Após o período mínimo de 48 horas, os corpos de prova foram desmoldados e curados em câmera úmida (umidade de $100 \%$ e temperatura de $24^{\circ} \mathrm{C}$ ). A aparência final dos painéis sanduíche produzidos encontra-se representada na Figura 5-3. Os corpos de prova foram analisados em relação ao comportamento sob flexão, eficiência de aderência entre lâminas e núcleo, e resposta mecânica sob carregamentos e descarregamentos cíclicos.

\subsubsection{Aderência entre Lâminas e Núcleo}

Tendo-se em vista que a performance do painel sanduíche depende consideravelmente de uma ligação satisfatória entre as lâminas e o núcleo, é essencial que a interface de aderência entre os compósitos laminados e o concreto celular autoclavado seja analisada de forma aprofundada. Para esse fim, a microestrutura da interface foi investigada por meio de micrografias, ao passo que a força de aderência entre os materiais foi verificada por ensaios de pull-off. Em geral, tem-se que a força de aderência entre argamassas e blocos depende da taxa de absorção inicial e capacidade de retenção de água da argamassa, tal como da rugosidade da superfície de contato. A interação com o concreto celular autoclavado, em particular, depende de seu teor de umidade e das condições do meio (RILEM, 1993). 


\subsubsection{Microestrutura da Interface}

Dentre os modos de verificação da interface entre argamassa e bloco, tal como a maneira em que a aderência se estabelece, está a análise microscópica da região de transição entre ambos os materiais. Para a obtenção das imagens, amostras de $20 \mathrm{~mm}$ x $20 \mathrm{~mm}$ x $20 \mathrm{~mm}$ foram seccionadas dos painéis utilizando uma serra diamantada Arotec.

Previamente à moldagem, os blocos de CCA foram submetidos a um condicionamento de 5 a $15 \%$ de teor de umidade e mantidos à temperatura ambiente por pelo menos $24 \mathrm{~h}$. Dessa forma, a superfície dos mesmos não se encontrou excessivamente seca a ponto de absorver a umidade da argamassa e endurecê-la no processo. Ademais, para evitar a perda de plasticidade da argamassa, a superfície dos blocos foi umedecida antes do processo de moldagem, como mencionado anteriormente.

Imagens gerais da estrutura, com menor poder de ampliação, foram obtidas a partir do microscópio estereoscópio Nikon modelo SMZ800N, equipamento ilustrado anteriormente na Figura 3-15. Detalhes mais precisos da interface foram obtidos com o microscópio eletrônico de mesa Hitachi TM3030, Figura 5-4-a. As amostras receberam deposição de prata para a realização de tal análise, como é possível observar na Figura 5-4-b. A extração de ar e água das amostras mostrou-se mais lenta que o padrão devido à porosidade do material, contabilizando 5 horas para o término do processo.

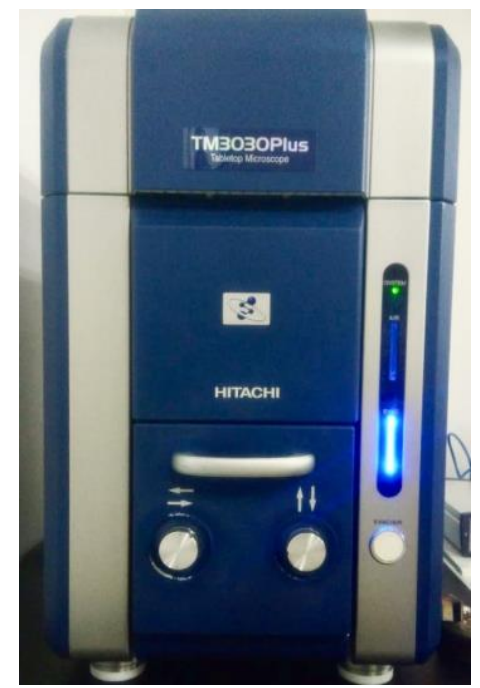

a)

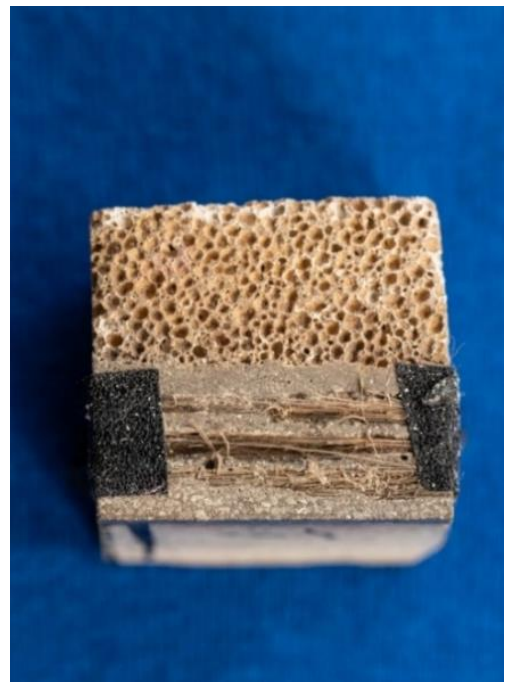

b)

Figura 5-4: Elementos utilizados na análise microscópica da interface dos painéis: a) microscópio Hitachi; b) detalhe da amostra preparada para a análise, com a superfície escurecida devido à deposição de prata 
O processo de obtenção das micrografias foi realizado no laboratório de microscopia do Centro de Tecnologia Mineral (CETEM), unidade de pesquisa do Ministério da Ciência, Tecnologia e Inovação (MCTI). O microscópio foi operado sob $15 \mathrm{kV}$ de tensão de aceleração e dois sinais diversos foram emitidos para a obtenção das imagens: elétrons retroespalhados (Backscattered-Electron, BSE) e elétrons secundários (Secondary Electrons, SE). O primeiro modo está associado a informações de contraste e identificação de diferentes fases; o segundo caso fornece detalhes sobre a superfície.

\subsubsection{Propriedade de Aderência}

A análise mecânica da propriedade de aderência dos painéis sanduíche foi obtida a partir de uma adaptação da NBR 13528 (2010). De acordo com o método sugerido pela norma, a resistência de aderência é medida por meio da força de tração necessária para extrair a amostra de seu substrato. No caso, o procedimento consistiu em circunscrever 12 corpos de prova cilíndricos, de $50 \mathrm{~mm}$ de diâmetro e com até $15 \mathrm{~mm}$ de profundidade total, em 4 painéis sanduíche de $350 \mathrm{~mm}$ x $100 \mathrm{~mm}$ x $90 \mathrm{~mm}$. Esse processo foi realizado por meio de uma perfuratriz com ponta diamantada Hilti e o corte das amostras pode ser visualizado na Figura 5-5-a.

Os painéis utilizados nesse ensaio foram moldados com uma largura maior do que a padrão (100 mm em substituição aos $60 \mathrm{~mm}$ usuais) devido ao requisito da norma referente a um diâmetro mínimo das amostras de ensaio. Essas foram distribuídas de forma centralizada e espaçadas em até $50 \mathrm{~mm}$ entre si, de forma que, para cada painel, 3 amostras válidas pudessem ser ensaiadas.

Um disco circular metálico foi colado à superfície do material por meio de massa plástica adesiva, sendo necessária a limpeza da área antes de sua aplicação e uma espera de 24 horas para a completa fixação do disco à amostra. As dimensões do disco podem ser verificadas na Figura 5-5-b. Posteriormente, uma barra de ligação foi utilizada para acoplar o disco ao equipamento de tração.

As dimensões das amostras, como diâmetro e profundidade de corte, foram medidas por paquímetro com precisão de $0,1 \mathrm{~mm}$. Uma das 12 amostras foi extraída do painel para a verificação da umidade do corpo de prova antes do ensaio, já que tal condição pode ser um indicativo de variações na aderência. A amostra foi pesada após extração e mantida em estufa em temperatura de $100-105^{\circ} \mathrm{C}$ até atingir massa constante. Em sequência, a mesma foi disposta 
em um dessecador até resfriamento. O cálculo de sua umidade foi realizado de acordo com a fórmula provida pela NBR 13528 (2010) e resultou em um teor de umidade de 11,78\%.

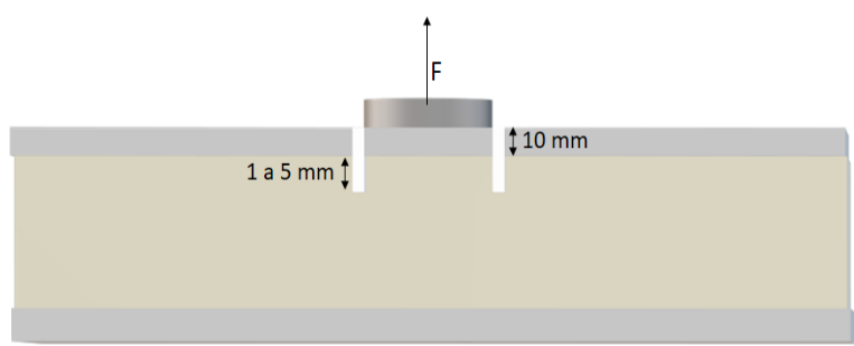

a)

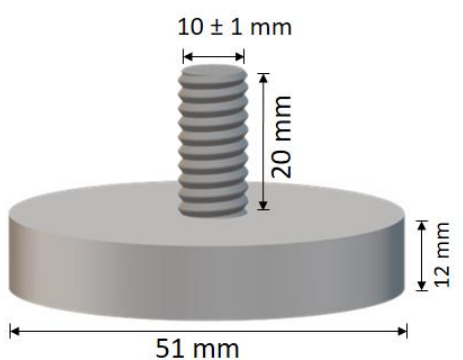

b)

Figura 5-5: Dimensões e características das amostras e do disco metálico: a) detalhe frontal do corte da perfuratriz no painel sanduíche em uma profundidade de até $5 \mathrm{~mm}$ da interface entre o compósito e o CCA; b) dimensões do disco metálico e da rosca, cujo furo lateral superior permitiu a ligação com o equipamento de ensaio

O ensaio de aderência foi realizado em uma MTS 810 com capacidade de $250 \mathrm{kN}$, com uma célula de carga de $2,5 \mathrm{kN}$ adicionada ao equipamento. $\mathrm{O}$ controle do ensaio foi realizado por deslocamento do atuador, sob uma taxa de $0,1 \mathrm{~mm} / \mathrm{min}$. Quatro barras metálicas foram utilizadas para restringir o movimento do painel durante o ensaio, sendo fixadas à base do arranjo experimental, como ilustrado na Figura 5-6-b. Para o ensaio de cada amostra, dispostas em posições diversas do material, o painel foi deslocado e o aparato remontado de forma centralizada, como na Figura 5-6-a, para que cada corpo de prova não se movesse durante a aplicação de força.

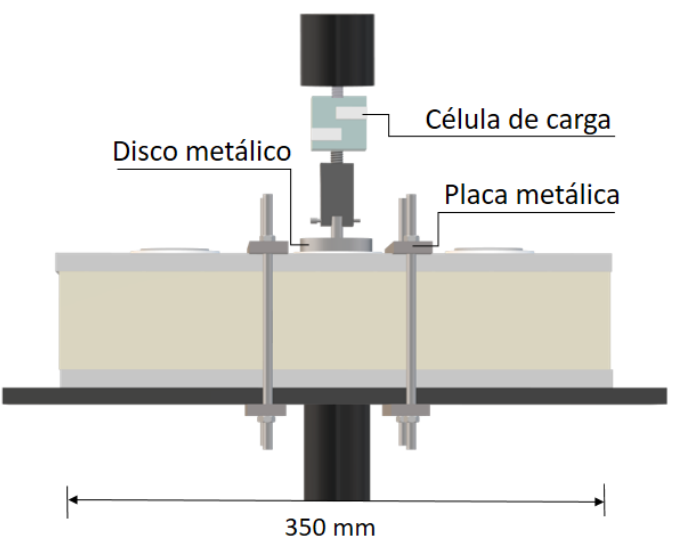

a)

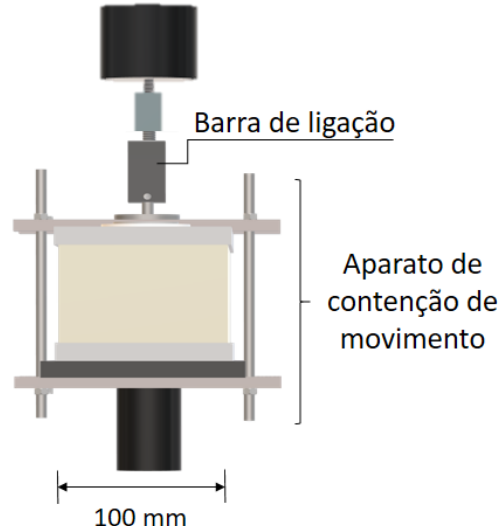

b)

Figura 5-6: Equipamento para a avaliação da força de aderência: a) posicionamento do disco metálico e elementos centralizados do ensaio; b) detalhe lateral, indicando o aparato de placas metálicas ao redor do painel e a barra de ligação ao disco como meio de acoplamento à MTS 
Os testes foram realizados, por consequência, através da aplicação de uma força direta de tração no disco metálico colado ao material. O aparato foi devidamente centralizado e alinhado ao corpo de prova, de modo que a força aplicada estivesse ortogonal à superfície. A força necessária para a ruptura do corpo de prova foi registrada, tal como seu modo de fratura. A resistência de aderência $(\mathrm{MPa})$ foi definida como a carga de ruptura $(\mathrm{N})$ dividida pela área transversal $\left(\mathrm{mm}^{2}\right)$ das amostras circulares.

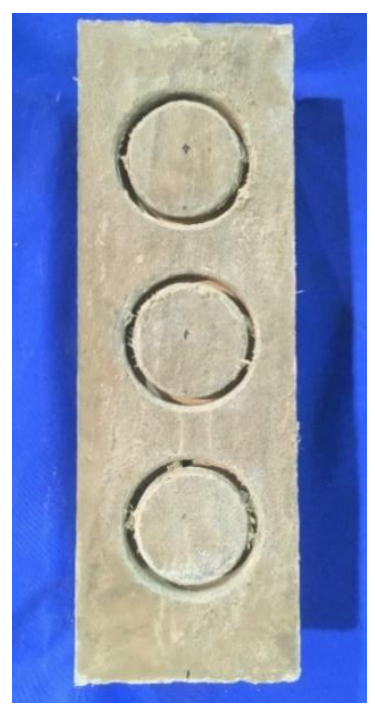

a)

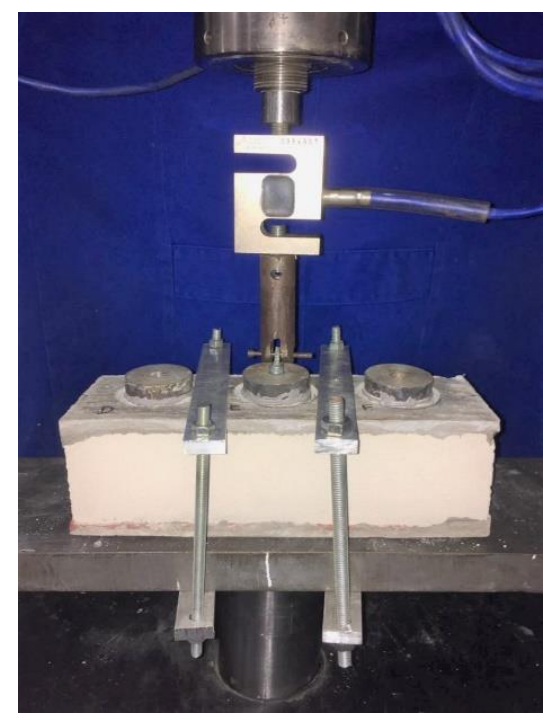

b)

Figura 5-7: Corpos de prova e aparato experimental: a) vista superior do painel e suas respectivas amostras circunscritas; b) ensaio das amostras após fixação dos discos em sua superfície, restrição do movimento do painel e centralização da aplicação de força.

\subsubsection{Comportamento Mecânico}

A fim de investigar o comportamento mecânico dos painéis sanduíche, ensaios de flexão foram realizados a partir de carregamentos monotônicos e cíclicos. A análise de flexão a quatro pontos é particularmente indicada para a avaliação da influência de novos materiais e da interação entre os elementos de um painel, como indica Frazão et al. (2018). Isso se deve ao fato de que, devido aos esforços de tração e compressão aos quais o corpo de prova é submetido, o ensaio permite verificar a capacidade das lâminas de suportar as tensões e do núcleo de transferir os esforços de cisalhamento. A escolha dos ensaios cíclicos, em contrapartida, justifica-se pela avaliação da resistência do material a diferentes tipos de carregamento, uma vez que, ao longo de sua vida útil, painéis sanduíche podem enfrentar condições agravantes em seu meio. 


\subsubsection{Flexão Monotônica}

Três corpos de prova de $350 \mathrm{~mm}$ x $60 \mathrm{~mm}$ x $90 \mathrm{~mm}$ foram ensaiados à flexão a quatro pontos aos 28 dias em uma MTS modelo 204.63, com capacidade de $100 \mathrm{kN}$. Os blocos de CCA utilizados na moldagem foram condicionados a um teor de umidade entre 5 e $15 \%$. O ensaio utilizou o mesmo espaçamento aplicado aos testes das placas cimentícias na seção 4.2.3.2, isto é, de $270 \mathrm{~mm}$ e 1/3 do vão entre os roletes de aplicação de força. Dois transdutores foram dispostos no meio do vão para registrar o deslocamento vertical das amostras. Os painéis foram ensaiados a uma taxa de deslocamento de $1 \mathrm{~mm} / \mathrm{min}$.

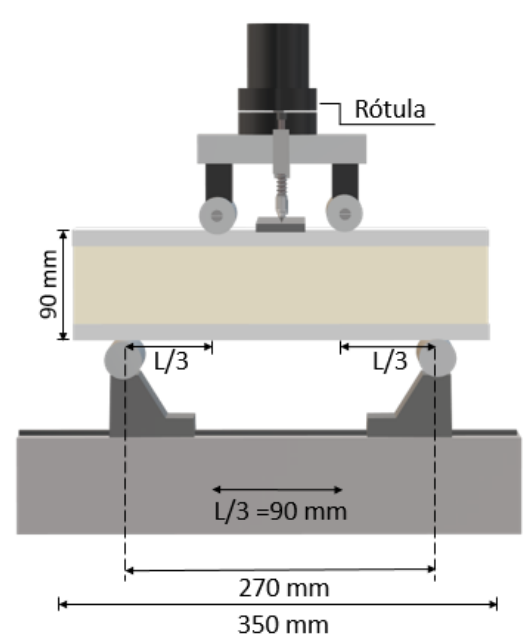

a)

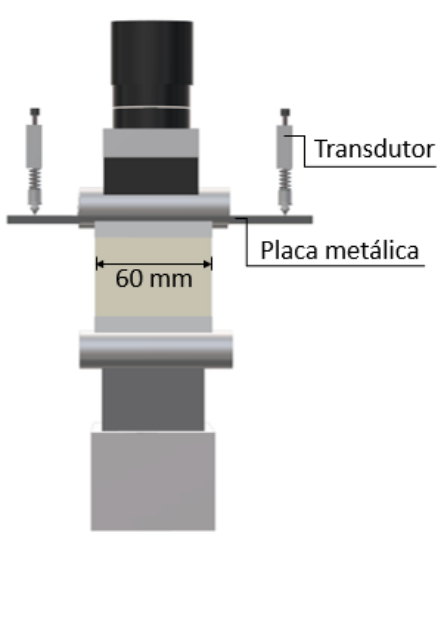

b)

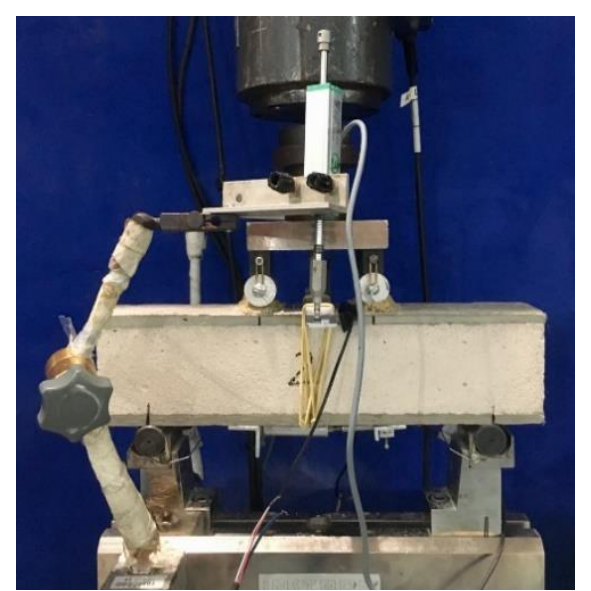

C)

Figura 5-8: Ensaio de flexão monotônico: a) configuração de 4 pontos com aplicação de força no terço médio; b) vista lateral do painel; c) aparato experimental

Devido às diferenças na altura dos blocos de CCA (inerentes à pré-fabricação), tal como na espessura das placas de compósitos (decorrentes do processo de moldagem), as dimensões de cada painel foram medidas por meio de paquímetro com precisão de $0,1 \mathrm{~mm}$. Três pontos de medida, extremidades e centro, foram estipulados para medir o comprimento (L), a largura (b), a espessura total do painel $\left(\mathrm{d}_{\mathrm{t}}\right)$, a espessura da lâmina superior $\left(\mathrm{t}_{1}\right)$, a espessura da lâmina inferior $\left(\mathrm{t}_{2}\right)$ e a espessura do núcleo (c), cuja média dos valores encontra-se na Tabela 5-1. Uma vez que há diferentes conotações para as dimensões do painel - seja de acordo com a teoria clássica de Allen (1969) ou com as normas ASTM - preferiu-se denominar a distância entre os centroides como $d_{c}$ e a altura total do corpo de prova como $d_{t}$ ou h, conforme indicado na Figura 5-9: 


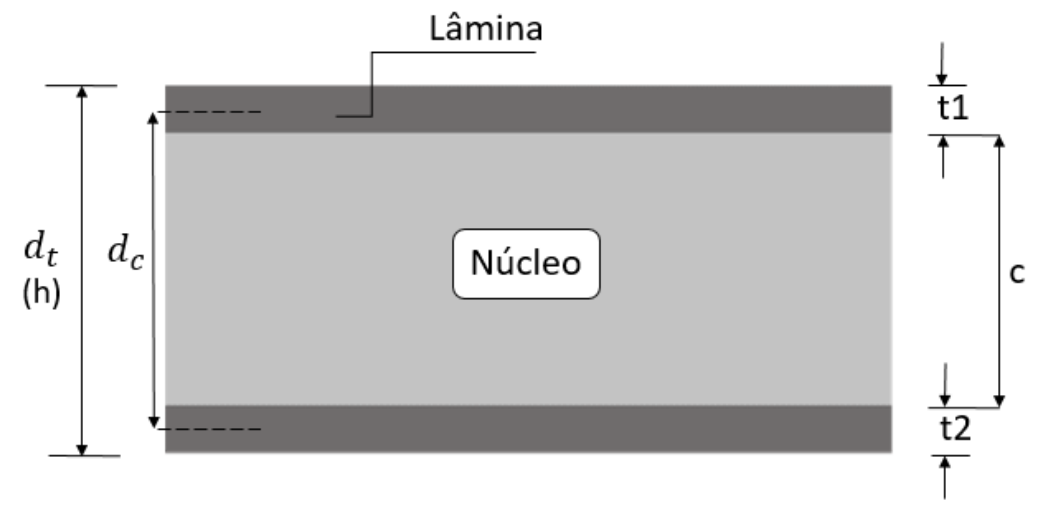

Figura 5-9: Ilustração representativa do painel sanduíche e suas respectivas dimensões

Tabela 5-1: Dimensões dos corpos de prova

\begin{tabular}{ccccccc}
\hline Painel & $\begin{array}{c}\mathbf{L} \\
(\mathbf{m m})\end{array}$ & $\begin{array}{c}\mathbf{b} \\
(\mathbf{m m})\end{array}$ & $\begin{array}{c}\mathbf{d}_{\mathbf{t}} \\
(\mathbf{m m})\end{array}$ & $\begin{array}{c}\mathbf{t}_{\mathbf{1}} \\
(\mathbf{m m})\end{array}$ & $\begin{array}{c}\mathbf{t}_{\mathbf{2}} \\
(\mathbf{m m})\end{array}$ & $\begin{array}{c}\mathbf{c} \\
(\mathbf{m m})\end{array}$ \\
\hline 1 & 351 & 61 & 89,8 & 9,8 & 11,3 & 68,7 \\
2 & 352 & 61,25 & 90,7 & 9,8 & 11,3 & 69,5 \\
3 & 351 & 60,5 & 89,8 & 8,8 & 12,7 & 68,3 \\
\hline
\end{tabular}

\subsubsection{Flexão Cíclica}

Para a avaliação do desempenho mecânico dos painéis sanduíche submetidos a ciclos de carregamento-descarregamento, o arranjo experimental seguiu os mesmos princípios apresentados pelo ensaio de flexão monotônico, tal como o mesmo espaçamento entre os pontos de força e disposição dos elementos de medida. A carga, em contrapartida, foi aplicada através do sinal emitido pelo LVDT, gerando ciclos de carregamento baseados em incrementos de deflexão variáveis. Tais pontos foram pré-definidos com base no comportamento da curva típica do ensaio monotônico, de maneira que o conjunto de ciclos foi aplicado em zonas características já previstas para os corpos de prova.

Dez ciclos foram aplicados no total, por controle do deslocamento do LVDT, para pontos fixos de deflexão: 0,2, 0,4 e 0,8 $\mathrm{mm}$ com taxa de deslocamento de $0,1 \mathrm{~mm} / \mathrm{min} ; 1,0,2,0$, $3,0,4,0$ e $5,0 \mathrm{~mm}$ com taxa de $0,5 \mathrm{~mm} / \mathrm{min} ; 7,5$ e $10,0 \mathrm{~mm}$, com taxa de $1 \mathrm{~mm} / \mathrm{min}$. Uma vez que esses valores de deflexão fossem alcançados durante o carregamento, o modo de ensaio seria revertido para controle de força, submetendo o corpo de prova a um descarregamento com taxa de $1 \mathrm{kN} / \mathrm{min}$ até um ponto mínimo de retorno. Esse ponto de retorno foi definido como um valor de força constante, onde $\mathrm{P}_{\min }=0,05 \mathrm{kN}$. 
Três painéis sanduíche de $350 \mathrm{~mm}$ x $60 \mathrm{~mm}$ x $90 \mathrm{~mm}$ foram ensaiados em um atuador servo hidráulico MTS 204.63. Devido à sensibilidade do ensaio, dois LVDTs foram utilizados no meio do vão: um de $5 \mathrm{~mm}$, localizado na parte superior da placa de suporte, e outro de $50 \mathrm{~mm}$, localizado na parte inferior, como demonstra a Figura 5-10-a. O LVDT de $5 \mathrm{~mm}$ foi utilizado para registrar a deflexão dos ciclos com maior precisão até o ponto de $3 \mathrm{~mm}$. Após atingi-lo, o controle foi revertido para o LVDT de $50 \mathrm{~mm}$, o qual prosseguiu com os ciclos restantes. A inversão da posição desse último LVDT foi utilizada para diminuir a pressão da mola e reduzir o ruído nos resultados. Ainda para fins de melhor sensibilidade, realizou-se o aterramento da base magnética dos LVDTs.

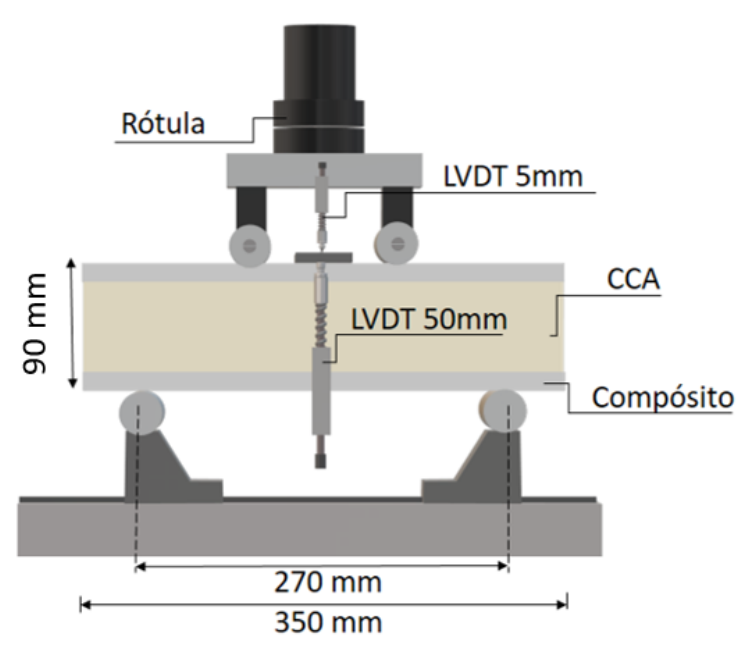

a)

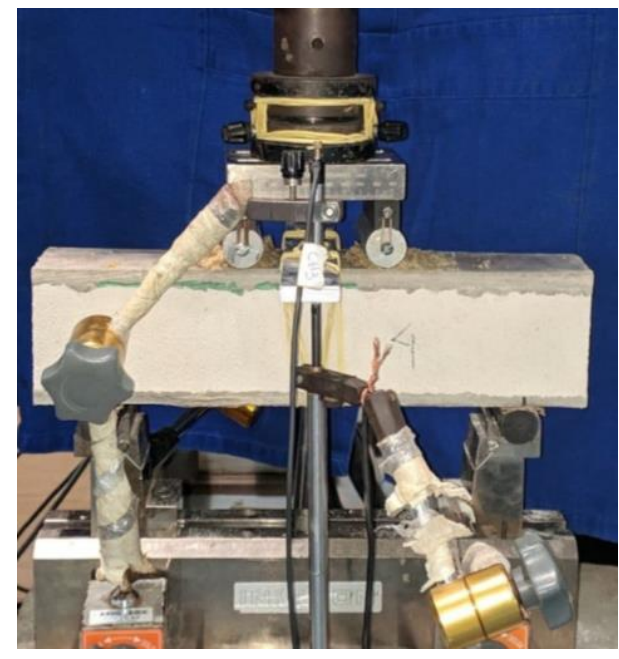

b)

Figura 5-10: Ensaio cíclico dos painéis sanduíche: a) dimensões do material e elementos do setup; b) equipamento e aparato utilizados

Devido a possíveis irregularidades na superfície dos compósitos, utilizou-se uma rótula no aparato experimental, de forma a equalizar a aplicação de força. Outra medida utilizada para a regularização do carregamento baseou-se na disposição de areia umedecida abaixo dos roletes, como ilustrado pela Figura 5-10-b.

\subsection{Resultados e Discussão}

Apresenta-se, nessa seção, o comportamento mecânico dos painéis sanduíche submetidos a ensaios de flexão a quatro pontos e de aderência. Os ensaios de flexão foram executados por meio de carregamentos monotônicos e cíclicos, de tal forma a avaliar a sua 
capacidade de transferência de esforços e comparar o desempenho apresentado pelos corpos de prova em ambas as condições. De maneira complementar, os ensaios de aderência, juntamente com imagens adquiridas através de um microscópio eletrônico de varredura (MEV), atuaram como meio de investigação da interface entre lâminas e núcleo, assim como da qualidade de interação entre os elementos constituintes. Os dados de força máxima, tenacidade, deformação e resistência encontram-se expostos em cada subseção, em seus valores médios e respectivos desvios padrão, de acordo com o foco de análise.

\subsubsection{Micrografia da Interface}

As imagens obtidas pelo microscópio estereoscópio encontram-se abaixo. Devido ao seu menor alcance de imagem, é possível distinguir as três camadas de fibras unidirecionais, distribuídas ao longo da matriz, na Figura 5-11-a.

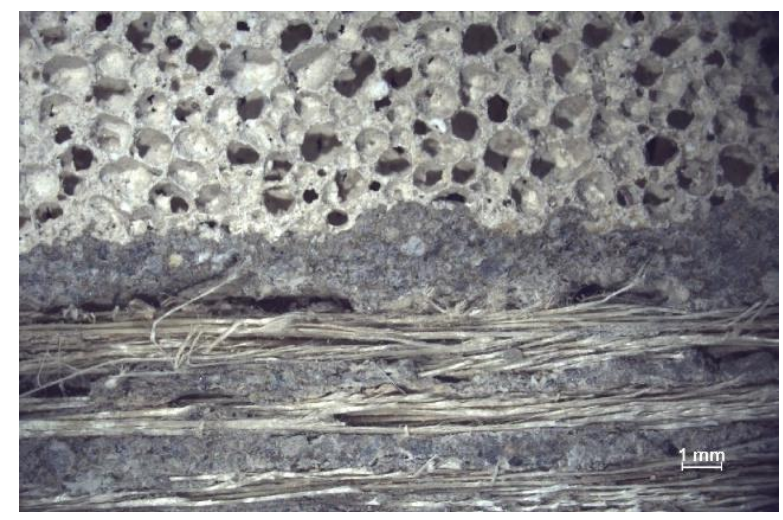

a)

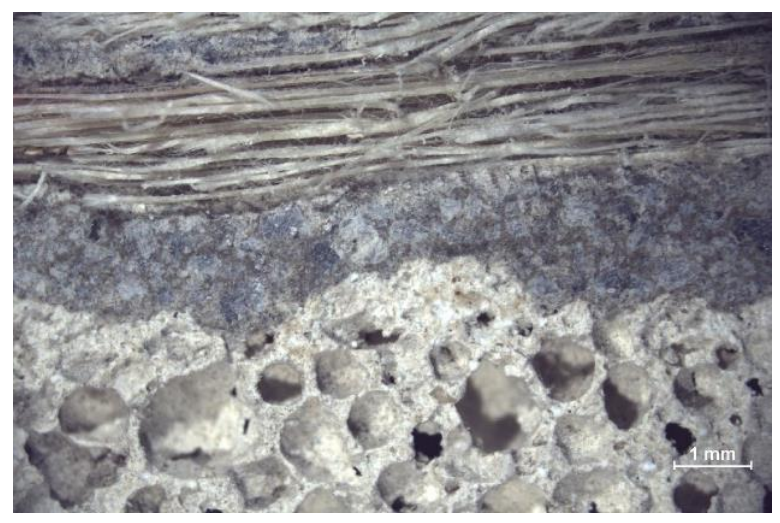

b)

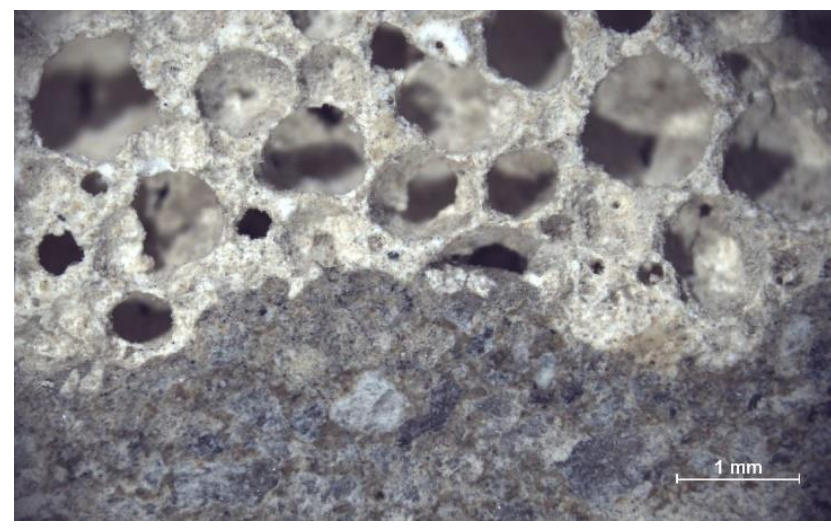

c)

Figura 5-11: Imagens das amostras: a) superfície inferior do painel, demonstrando as camadas de fibra de reforço; b) superfície superior do painel, detalhe da interface de contato entre os elementos; c) detalhe para a superfície porosa do CCA e de sua adesão satisfatória com a argamassa 
Nota-se, através das imagens, que a transição entre a argamassa e o bloco de CCA não apresenta rupturas visíveis ou vazios. O CCA, por ser um material poroso e com superfície rugosa, consegue assimilar a argamassa ao seu próprio material. De maneira a corroborar a qualidade da adesão entre os materiais, micrografias da interface foram obtidas por um microscópio eletrônico de varredura (MEV), como exposto na Figura 5-12.

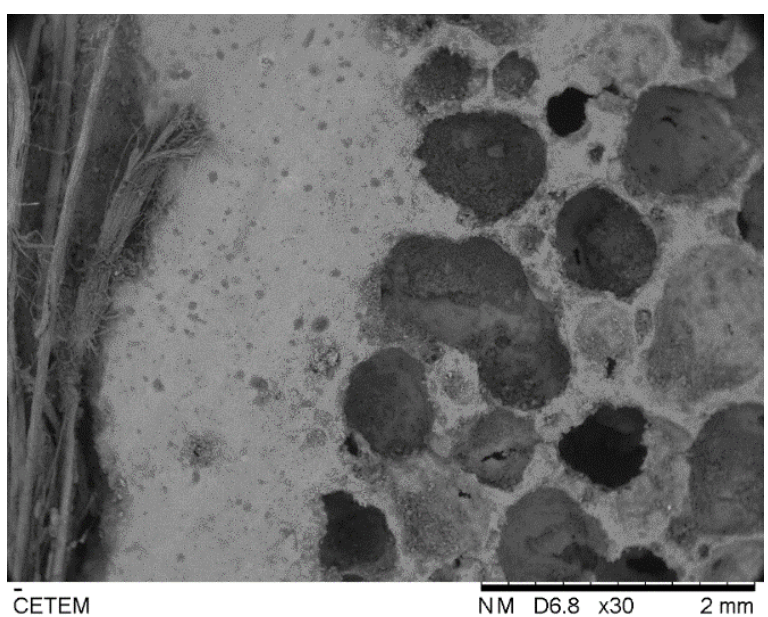

a)

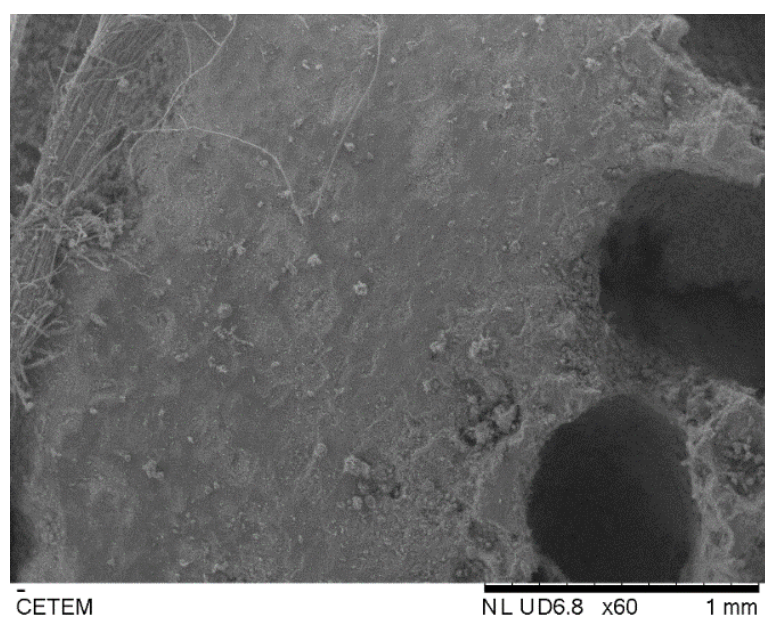

b)

Figura 5-12: Micrografias da interface entre lâminas e núcleo: a) imagem obtida pelo modo BSE demonstra uma única fase de material, sem aparentes transições; b) imagem obtida pelo modo SE não exibe diferenças na topografia da amostra

A Figura 5-12-a demonstra a investigação de possíveis mudanças de fase nas amostras (modo BSE), na qual é possível notar apenas uma leve diferença (em tons de cinza) na transição dos materiais, de forma que a imagem indica um material íntegro, com uma união satisfatória entre os elementos. A Figura 5-12-b, que possui como objetivo identificar variações na superfície da amostra (modo SE), não sugere mudanças na topografia do material - indicativo adicional da qualidade de aderência entre lâminas-núcleo. Ademais, nota-se que, em ambas as micrografias, não há qualquer aparente porosidade na área de transição lâmina-núcleo, aspecto característico de uma aderência falha entre um substrato poroso e a argamassa.

Tem-se que um dos fatores favoráveis à aderência entre os elementos está na consistência da matriz, a qual foi planejada para ser suficientemente fluida de forma a penetrar no tecido de curauá utilizado como reforço. Assim, uma argamassa mais fluida é adequada para a superfície do CCA, compensando o processo de sucção de seus poros. A interação satisfatória entre ambos os materiais forneceu aos painéis uma aderência eficaz e transição suave entre o bloco de concreto celular autoclavado e os compósitos laminares. 


\subsubsection{Ensaio de Aderência (pull-off)}

A eficácia da aderência entre lâminas e núcleo foi verificada a partir do ensaio de 11 corpos de prova, aplicando-se uma força de tração em discos circunscritos nos painéis. Os valores médios obtidos, como a resistência de aderência (MPa), calculada por meio da relação entre carga de ruptura $(\mathrm{N})$ e área da seção transversal $\left(\mathrm{mm}^{2}\right)$, encontram-se resumidos na Tabela 5-2, juntamente com os desvios padrão.

Tabela 5-2: Resultados do ensaio de aderência para cada amostra ensaiada dos painéis sanduíche

\begin{tabular}{cccccc}
\hline Amostra & $\begin{array}{c}\text { Área } \\
\left(\mathbf{m m}^{2}\right)\end{array}$ & $\begin{array}{c}\text { Carga de } \\
\text { Ruptura } \\
(\mathbf{N})\end{array}$ & $\begin{array}{c}\text { Resistência de } \\
\text { Aderência } \\
(\mathbf{M P a})\end{array}$ & Modo de Ruptura \\
\hline 1 & 2206 & 685 & 0,31 & Substrato & (Excluído) \\
2 & 2210 & 612 & 0,28 & Argamassa & (Excluído) \\
3 & 2165 & 254 & 0,12 & Argamassa & \\
4 & 2206 & 169 & 0,08 & Argamassa & \\
5 & 2219 & 327 & 0,15 & Argamassa \\
6 & 2227 & 114 & 0,05 & Argamassa & \\
7 & 2190 & 224 & 0,10 & Argamassa & \\
8 & 2128 & 31 & 0,01 & Argamassa & (Excluído) \\
9 & 2144 & 54 & 0,03 & Argamassa & \\
10 & 2185 & 259 & 0,12 & Argamassa & \\
11 & 2194 & 140 & 0,06 & Argamassa & \\
Média & $\mathbf{2 1 9 1}$ & $\mathbf{1 9 3}$ & $\mathbf{0 , 0 9}$ & & \\
Desvio & $\mathbf{2 7}$ & $\mathbf{9 0}$ & $\mathbf{0 , 0 4}$ & & \\
Padrão & & & & & \\
\hline
\end{tabular}

O detalhamento dos possíveis modos de ruptura, como indicado pela NBR 13528 (2010), encontra-se ilustrado na Figura 5-13. Para a reprodução do caso, considera-se a estrutura das amostras do painel sanduíche, onde a argamassa é representada pela placa cimentícia e o substrato pelo concreto celular autoclavado. 

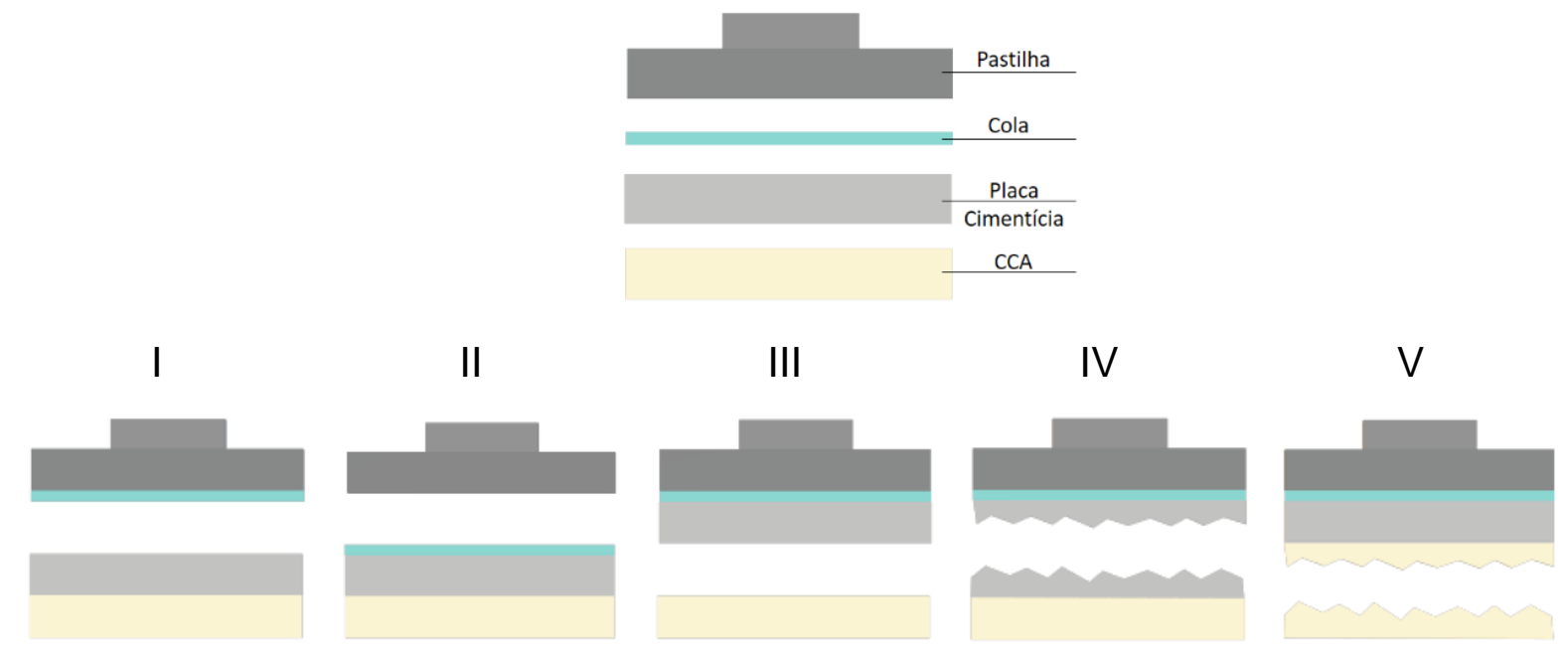

Figura 5-13: Acima, elementos presentes nas amostras do ensaio de aderência, na qual o disco, a cola, o compósito e o CCA encontram-se representados separadamente; abaixo, possíveis modos de ruptura dos painéis sanduíche no ensaio de aderência (pull-off) de acordo com a interface separada ou rompida

Os modos de ruptura dividem-se de acordo com o comportamento da interface, a qual pode ser simplesmente separada entre dois elementos ou sofrer fraturas no processo de tração. Em geral, os locais de fratura resumem-se a:

I. Interface argamassa/cola;

II. Interface cola/pastilha;

III. Interface argamassa/substrato;

IV. Argamassa;

V. Substrato.

Tem-se que, quando a ruptura ocorre na interface entre a argamassa e o substrato (tipo III), a força de ruptura obtida representa verdadeiramente a resistência da aderência entre os dois elementos. Em caso de outros tipos de ruptura (tipos IV e V), a aderência entre as camadas não pode ser definida em exatidão, mas se pode concluir que é maior do que o valor obtido em ensaio. Em contrapartida, para o tipo de ruptura caracterizado pela separação da cola, o resultado deve ser desprezado, pois indica que a união entre o disco e a superfície não foi suficiente para transferir a força de tração. Os modos de ruptura obtidos durante o ensaio, para cada amostra, encontram-se na Figura 5-14. 

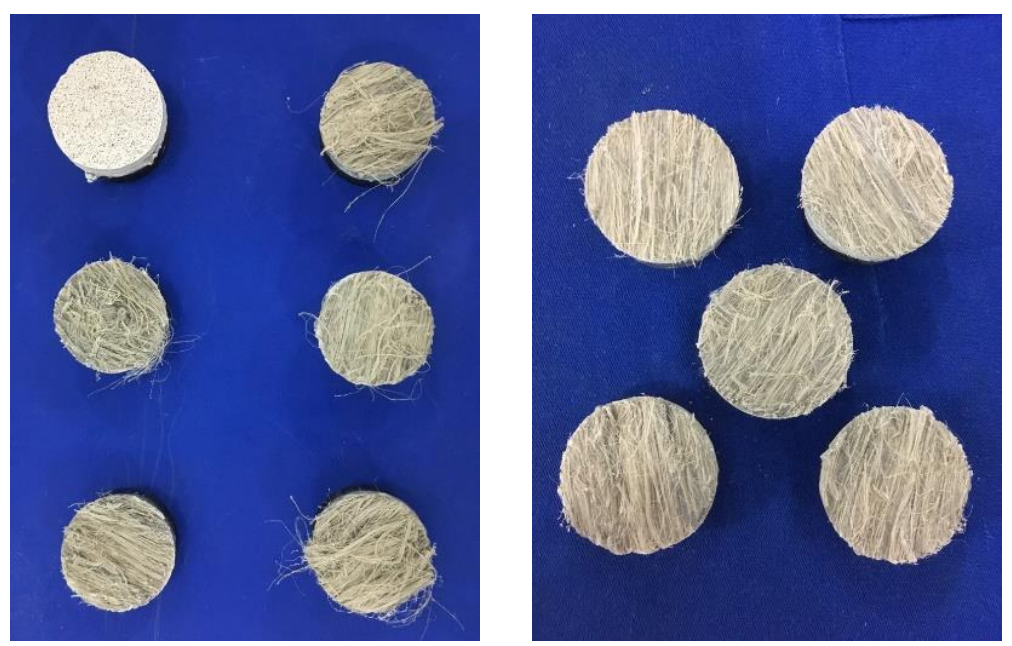

Figura 5-14: Amostras ensaiadas e suas respectivas interfaces de ruptura, nas quais é possível identificar com facilidade a área de reforço de fibras nos corpos de prova extraídos

Como observado na Tabela 5-2, resultados com comportamento díspar foram excluídos para obter uma análise da interface mais condizente com o painel sanduíche avaliado. Tais outliers apresentaram resistências muito superiores ou inferiores à média dos outros corpos de prova possivelmente devido a variações experimentais.

Dessa maneira, a maior resistência de aderência obtida foi de $0,15 \mathrm{MPa}$ e todos os modos de ruptura ocorreram por falha do compósito (isto é, modo de ruptura IV) - com exceção de uma única amostra, com ruptura pelo CCA (modo de ruptura V), que apresentou um valor de força excessivamente alto e, portanto, não representa o comportamento do material. De forma análoga, os ensaios de pull-off realizados por Frazão et al. (2018) entre compósitos laminares de sisal e núcleo de concreto leve com fibras de polipropileno apresentaram falha do tipo coesiva, com resistência de 0,95 $\mathrm{MPa}$ e 1,27 MPa para as camadas superior e inferior, respectivamente.

Em geral, a ruptura ocorre no plano mais fraco dos elementos envolvidos. No caso, isso indica que a adição de fibras de curauá cria pontos de fragilidade na matriz no sentido ortogonal, tornando as superfícies entre as camadas de fibras e a matriz mais suscetíveis às forças de tração. Ademais, como o modo de ruptura não ocorreu entre as superfícies de aderência (compósito e CCA), o valor médio de resistência à tração obtido representa um limite inferior para a aderência, ou seja, com média superior à aderência da interface.

De acordo com Davies (2008), para que um painel sanduíche detenha uma aderência satisfatória entre as duas lâminas e o núcleo a curto e longo prazos, deve-se ter como referência uma resistência à tração mínima de $0,075 \mathrm{MPa}$. Os corpos de prova ensaiados apresentaram 
resistência média superior a $0,09 \mathrm{MPa}$, demonstrando que as três camadas detêm aderência adequada.

\subsubsection{Ensaio Monotônico de Flexão a Quatro Pontos}

As curvas obtidas para o ensaio de flexão a quatro pontos para os três painéis, tal como o comportamento médio dos mesmos, encontra-se exposto na Figura 5-15, a partir da relação entre força $(\mathrm{kN})$ e deflexão $(\mathrm{mm})$.

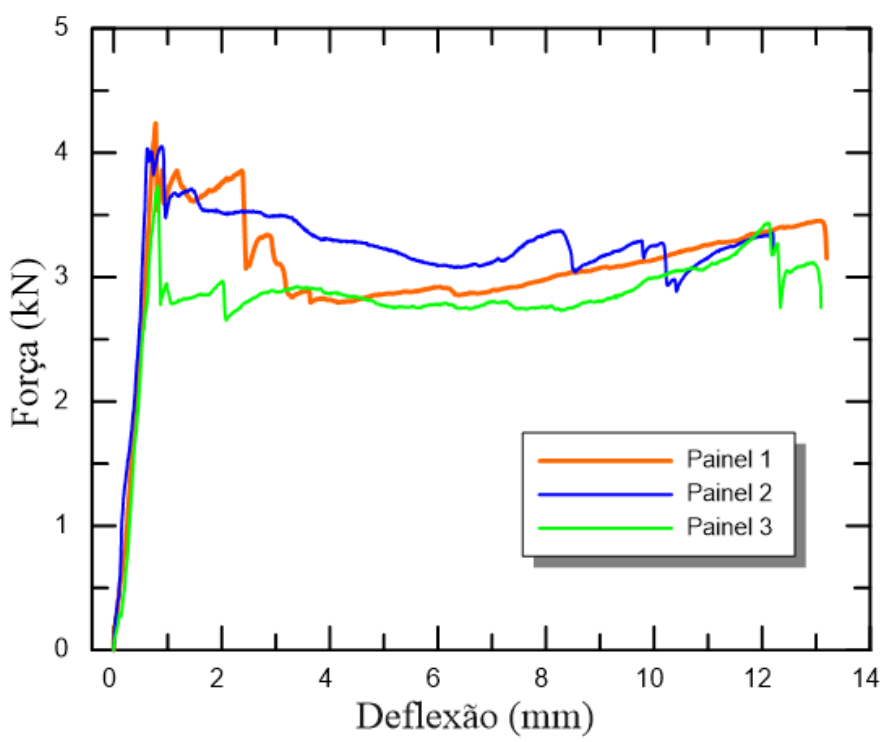

Figura 5-15: Curvas de força-deflexão de cada painel submetido à flexão e o comportamento médio de todos os corpos de prova

Durante o ensaio, registrou-se a força máxima aplicada pelo atuador, tal como a sua deflexão correspondente, obtida pela média dos deslocamentos do meio do vão. A tenacidade dos corpos de prova foi obtida em dois pontos principais: o de força máxima $\left(\mathrm{P}_{\max }\right)$ e o correspondente a $12 \mathrm{~mm}$ de deflexão, cuja utilidade é explicitada na seção 5.3.4. Ambos os valores foram obtidos por meio da área abaixo das curvas. A média e o desvio padrão foram calculados para todos os corpos de prova: 
Tabela 5-3: Propriedades mecânicas dos painéis sob flexão a quatro pontos (monotônico)

\begin{tabular}{ccccc}
\hline $\begin{array}{c}\text { Painel } \\
\text { Sanduíche }\end{array}$ & $\begin{array}{c}\text { Força } \\
\text { Máxima } \\
(\mathbf{N})\end{array}$ & $\begin{array}{c}\text { Deflexão } \\
\text { em } \mathbf{P}_{\max } \\
(\mathbf{m m})\end{array}$ & $\begin{array}{c}\text { Tenacidade } \\
\text { em } \mathbf{P}_{\mathbf{m a x}} \\
(\mathbf{J})\end{array}$ & $\begin{array}{c}\text { Tenacidade } \\
\text { em 12 } \mathbf{~ m m} \\
(\mathbf{J})\end{array}$ \\
\hline 1 & 4238 & 0,776 & 1,51 & 36,57 \\
2 & 4055 & 0,889 & 2,18 & 38,65 \\
3 & 3732 & 0,812 & 1,42 & 33,60 \\
Média & $\mathbf{4 0 0 8}$ & $\mathbf{0 , 8 2 6}$ & $\mathbf{1 , 7 0}$ & $\mathbf{3 6 , 2 7}$ \\
Desvio Padrão & $\mathbf{2 5 6}$ & $\mathbf{0 , 0 6 0}$ & $\mathbf{0 , 4 1}$ & $\mathbf{2 , 5 4}$ \\
\hline
\end{tabular}

Observa-se que os corpos de prova apresentaram um padrão de comportamento caracterizado por ganhos de resistência e rigidez similares entre si até o ponto de força máxima (usualmente em torno de $4 \mathrm{kN}$ ) e, a despeito da perda gradual de capacidade de carga, observouse um comportamento dúctil, com satisfatória capacidade de deflexão. A Figura 5-16 destaca a área de transição entre diferentes padrões de comportamento dos painéis até os seus respectivos $5 \mathrm{~mm}$ de deflexão registrados:

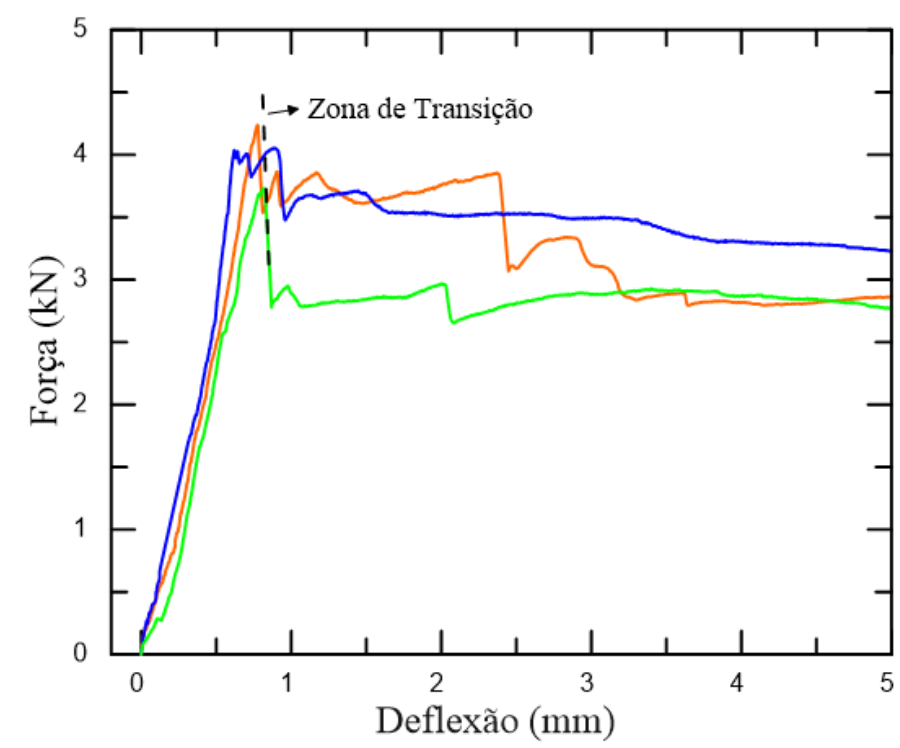

Figura 5-16: Divisão das zonas linear e de fissuração no comportamento dos painéis sob flexão a quatro pontos

Inicialmente, nota-se que o núcleo e as lâminas se comportam de maneira elástico-linear até o aparecimento das primeiras fissuras, ponto de limite da zona elástica. Assim, há a formação de fissuras múltiplas nas lâminas e núcleo dos painéis. A queda repentina de força, causada principalmente por fissuras de cisalhamento no núcleo, representa uma mudança significativa na inclinação da curva, sendo definida como uma zona de transição, conforme 
definido pela ASTM C393 (2011). Após esse ponto, a propagação e aumento das fissuras do núcleo, tal como a prolongação das tensões nas lâminas, associadas a uma menor aderência entre os elementos, levam a perdas visíveis de resistência. O comportamento de deflection softening se estabelece até o esgotamento da capacidade do painel.

A resistência e a capacidade de absorção de energia alcançadas pelos corpos de prova mostraram-se equivalentes a painéis sanduíche de estrutura similar. Ensaios de flexão a três pontos, com vão de 220 mm, foram realizados por Dey et al. (2015) em painéis sanduíche com lâminas de concreto reforçado com 2 camadas de tecido de vidro-AR e núcleo de CCA, de dimensões de $50 \mathrm{~mm}$ x $100 \mathrm{~mm}$ x $250 \mathrm{~mm}$ - geometria similar aos painéis desenvolvidos. Os corpos de prova alcançaram uma força máxima de 2766 N, obtendo resistência à flexão de 1,6 MPa e deflexão de 1,40 mm no ponto de carga máxima. A tenacidade em $1 \mathrm{~mm}$ de deflexão, de 1,45 MPa, mostrou-se análoga à obtida para os painéis no ponto de força máxima. A comparação direta entre os resultados encontra-se na Figura 5-17.

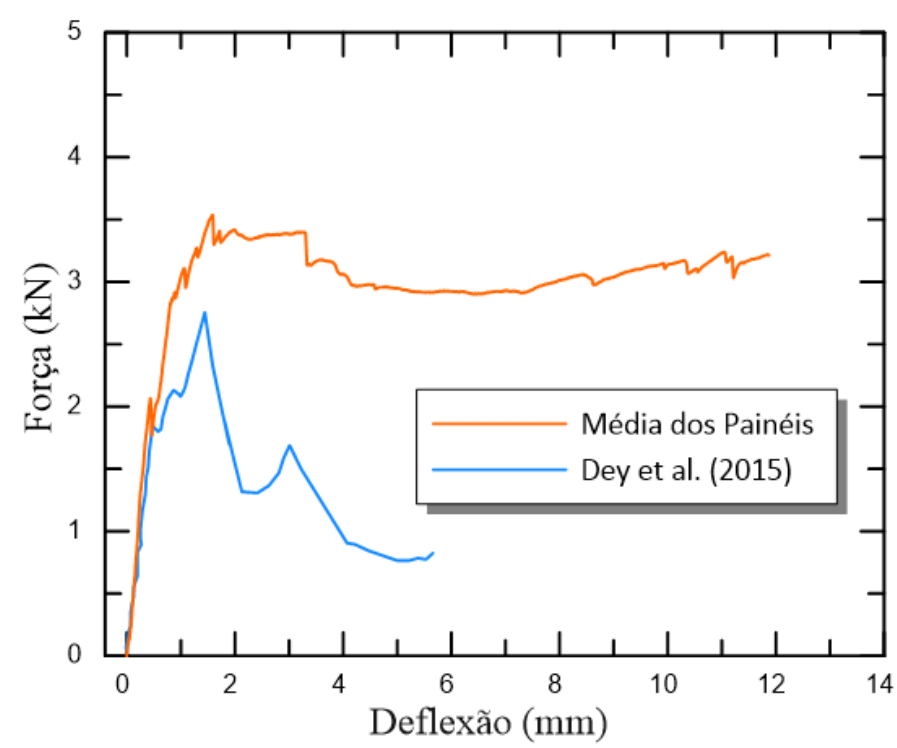

Figura 5-17: Comparação entre o desempenho médio da estrutura sanduíche e o da referência análoga

Verifica-se que os painéis com fibras naturais apresentaram uma capacidade de deformação consideravelmente maior, o que indica que o uso de fibras longas de curauá levou a uma melhor capacidade de controle de fissuras e ductilidade. A comparação do desempenho do painel sanduíche em relação ao bloco de CCA, por sua vez, encontra-se descrita no item 5.3.3.2.

Uma outra estrutura similar foi desenvolvida por Frazão et al. (2018), composta por painéis sanduíche com lâminas de compósitos cimentícios reforçados com fibras de sisal 
associadas a um núcleo de concreto leve reforçado com fibras de polipropileno (PP). Os corpos de prova com fibras longas de sisal obtiveram um padrão pronunciado de deflection hardening até o ponto de $18,14 \mathrm{kN}$ e 10,40 mm de deflexão. Nota-se que a discrepância de desempenho entre essa estrutura e o modelo desenvolvido se dá majoritariamente devido às diferenças de resistência do núcleo, uma vez que o CCA obteve 2,3 $\mathrm{MPa}$ e 1,49 $\mathrm{GPa}$ de resistência à compressão e módulo de elasticidade, respectivamente, ao passo que o concreto leve com fibras de PP alcançaram 45,13 MPa e 22,67 GPa. Os compósitos reforçados com sisal, em contrapartida, apresentaram performance inferior, com resistência à flexão última de 8,60 MPa, enquanto os compósitos de curauá exibiram 32,16 MPa no ensaio de flexão a quatro pontos.

Para a análise mais aprofundada do comportamento mecânico dos painéis sob flexão, equações clássicas e as normas ASTM D7249 (2006) e ASTM D7250 (2009) foram utilizadas para o cálculo das propriedades mais importantes de cada elemento analisado: para o painel sanduíche, a rigidez à flexão e a rigidez ao cisalhamento; para o núcleo, a resistência ao cisalhamento e o módulo de cisalhamento; para as lâminas, a resistência à compressão e à tração.

As normas indicadas estipulam dimensões padrões para os painéis sanduíche, as quais os corpos de prova produzidos não se adequam. Contudo, os corpos de prova ensaiados não ultrapassam o limite de largura expresso (igual a 6 vezes a espessura total do painel ou metade do vão), de maneira que as simplificações das equações propostas pelas normas podem ser aplicadas para o caso.

\subsubsection{Painéis Sanduíche}

\section{- Rigidez à Flexão e Rigidez ao Cisalhamento Transversal}

A rigidez à flexão do painel, propriedade dependente do módulo de elasticidade e do momento de inércia dos elementos, representa a resistência do corpo de prova à deformação de flexão. Como mencionado anteriormente na seção 2.4.2, a rigidez à flexão de painéis sanduíche detém vantagem em relação a outros tipos de construção devido à distância centroidal entre as lâminas por conta da adição de um núcleo espesso.

A rigidez ao cisalhamento contabiliza a influência de esforços de cisalhamento que atravessam a seção transversal. Tem-se que tal propriedade de um painel sanduíche é usualmente inferior à propriedade equivalente de um membro homogêneo de igual rigidez à 
flexão, devido ao uso de um núcleo leve e mais suscetível ao cisalhamento. Dessa forma, esse cálculo não pode ser desconsiderado com frequência na avaliação da estabilidade e resistência de um painel sanduíche (NORDSTRAND; CARLSSON; ALLEN, 1994).

Para o cálculo da rigidez à flexão dos painéis, pode-se fazer uso de equações clássicas, como a (Eq. 2-1, mencionada no item 2.4.2, a qual considera a soma das rigidezes de ambas as lâminas e do núcleo. Contudo, para fins de simplificação da equação, as condições ((Eq. 2-2) e ((Eq. 2-3) devem ser aplicadas ao painel sanduíche para que termos possam ser suprimidos.

Para fins de representação, as condições indicadas utilizaram as dimensões originais, ou seja, $350 \mathrm{~mm}$ x $60 \mathrm{~mm}$ x $90 \mathrm{~mm}$. Expressando os termos em mm, tem-se que:

$$
\frac{d_{c}}{t}=\frac{h+c}{2 t}=\frac{90+70}{20}=8,0>5,77
$$

Consequentemente, isso implica que a condição ((Eq. 2-2) é satisfeita para o painel e o primeiro termo da Eq. (Eq. 2-1 pode ser desprezado. Para o cálculo da condição ((Eq. 2-3), é necessário utilizar dados previamente calculados: o módulo de elasticidade do núcleo, obtido na seção 3.4.5, e o módulo de elasticidade da lâmina, referente ao valor encontrado na seção 4.3.3. Tem-se que $\mathrm{E}_{\mathrm{c}}=1,49 \mathrm{GPa}$ e $\mathrm{E}_{\mathrm{f}}=26,85 \mathrm{GPa}$, respectivamente. Logo:

$$
6 \frac{E_{f}}{E_{c}} \frac{t}{c}\left(\frac{d_{c}}{c}\right)^{2}=6 \frac{26,85}{1,49} \frac{10}{70}\left(\frac{80}{70}\right)^{2}=20,17<100
$$

Uma vez que o valor obtido é inferior a 100, a condição (Eq. 2-3) não pode ser satisfeita e o terceiro termo da equação de rigidez não poderá ser desconsiderado. Para o cálculo da rigidez do painel, a equação mais adequada encontra-se abaixo e o resultado na Tabela 5-4. Os resultados são válidos até a fissuração dos corpos de prova.

$$
D=E_{f} \frac{b t d_{c}^{2}}{2}+E_{c} \frac{b c^{3}}{12}
$$

Onde:

$\mathrm{D}=$ rigidez à flexão da viga $\left(\mathrm{N} \cdot \mathrm{mm}^{2}\right)$;

$\mathrm{E}_{\mathrm{f}}=$ módulo de elasticidade das lâminas $\left(\mathrm{N} / \mathrm{mm}^{2}\right)$;

$\mathrm{E}_{\mathrm{c}}=$ módulo de elasticidade do núcleo $\left(\mathrm{N} / \mathrm{mm}^{2}\right)$; 
$\mathrm{b}=$ largura da viga $(\mathrm{mm})$;

$\mathrm{t}=$ espessura das lâminas $(\mathrm{mm})$;

$\mathrm{c}=$ espessura do núcleo $(\mathrm{mm})$;

$\mathrm{d}_{\mathrm{c}}=$ distância entre os centróides da lâmina $(\mathrm{mm})$;

Tabela 5-4: Dimensões dos painéis utilizadas para o cálculo e os valores médios da rigidez à flexão

\begin{tabular}{cccccc}
\hline Painel & $\mathbf{b}(\mathbf{m m})$ & tmédio $(\mathbf{m m})$ & $\mathbf{d} \mathbf{c}(\mathbf{m m})$ & $\mathbf{c}(\mathbf{m m})$ & $\mathbf{D}\left(\mathbf{N} \cdot \mathbf{m m}^{\mathbf{2}}\right)$ \\
\hline 1 & 61,0 & 10,6 & 79,3 & 68,7 & $5,69 \mathrm{E}+10$ \\
2 & 61,25 & 10,6 & 80,1 & 69,5 & $5,84 \mathrm{E}+10$ \\
3 & 60,5 & 10,8 & 79,1 & 68,3 & $5,70 \mathrm{E}+10$ \\
Média & $\mathbf{6 0 , 9}$ & $\mathbf{1 0 , 6}$ & $\mathbf{7 9 , 5}$ & $\mathbf{6 8 , 8}$ & $\mathbf{5 , 7 4 E + 1 0}$ \\
Desvio Padrão & $\mathbf{0 , 3 8}$ & $\mathbf{0 , 1}$ & $\mathbf{0 , 5}$ & $\mathbf{0 , 6}$ & $\mathbf{8 , 2 2 E + 0 8}$ \\
\hline
\end{tabular}

A rigidez ao cisalhamento transversal, por sua vez, pode ser obtida através da norma ASTM D7250 (2009), a qual estipula que, caso o módulo de elasticidade da lâmina já seja conhecido, uma única configuração de ensaio é suficiente para obter as propriedades de cisalhamento - nesse caso, a configuração de flexão a quatro pontos com aplicação de força no terço médio. Por conseguinte, esta fórmula pode ser aplicada:

$$
U=\frac{P(S-L)}{4\left[\Delta-\frac{P\left(2 S^{2}-3 S L^{2}+L^{3}\right.}{96 D}\right]}
$$

Onde:

$\mathrm{U}=$ rigidez ao cisalhamento transversal $(\mathrm{N})$;

$\mathrm{P}=$ força aplicada no ponto $(\mathrm{N})$;

$\mathrm{S}=$ comprimento do vão total $(\mathrm{mm})$;

$\mathrm{L}=$ comprimento de vão entre os pontos de aplicação de força $(\mathrm{mm})$;

$\mathrm{D}=$ rigidez à flexão da viga $\left(\mathrm{N} . \mathrm{mm}^{2}\right)$;

$\Delta=$ deflexão no meio do vão $(\mathrm{mm})$;

A rigidez ao cisalhamento foi calculada para cada corpo de prova para uma série de forças $(\mathrm{P})$, com suas respectivas deflexões $(\Delta)$, até o ponto de carga máxima aplicada $\left(\mathrm{P}_{\max }\right)$. Os valores devem ser calculados para um mínimo de 10 níveis de força espaçados igualmente ao longo da curva força-deflexão. Estipulou-se um intervalo de 0,05 mm entre cada força 
aplicada na fórmula até o ponto máximo de carga. O valor final de U para cada corpo de prova é dado pela média dos valores calculados para as forças consideradas na série de pontos. Para todos os corpos de prova, a média da rigidez à flexão (D) foi utilizada na fórmula, isto é, 5,74 x $10^{10}$ N.mm². Tem-se:

Tabela 5-5: Forças máximas alcançadas pelos painéis e utilizadas como ponto limite do cálculo de rigidez ao cisalhamento transversal

\begin{tabular}{ccc}
\hline Painel & Pmax $(\mathbf{N})$ & $\mathbf{U}(\mathbf{N})$ \\
\hline 1 & 4238 & $2,26 \mathrm{E}+05$ \\
2 & 4055 & $2,75 \mathrm{E}+05$ \\
3 & 3732 & $1,86 \mathrm{E}+05$ \\
Média & $\mathbf{4 0 0 8}$ & $\mathbf{2 , 2 9 E}+\mathbf{0 5}$ \\
Desvio Padrão & $\mathbf{2 5 6}$ & $\mathbf{4 , 4 5 E}+\mathbf{0 4}$ \\
\hline
\end{tabular}

Estruturas sanduíche com lâminas reforçadas com fibras sintéticas e núcleo de isolamento térmico podem ser igualmente utilizadas como meio de comparação. Almeida (2009) desenvolveu painéis sanduíche com lâminas de polímero reforçado com fibras de vidro e núcleo de espuma rígida de poliuretano. As propriedades de flexão resumiram-se a: 3,96 kN de força máxima, 4,69 MPa de tensão máxima nas fibras externas e 751,60 kN de rigidez ao cisalhamento. Uddin et al.(2006) desenvolveram painéis sanduíche com núcleo de CCA e lâminas de polímero reforçado com fibras de carbono em matriz de resina epóxi, obtendo 12 $\mathrm{kN}$ de resistência e 1,86 mm de deflexão no pico de força. Colombo et al. (2015) ensaiaram painéis sanduíche com lâminas de TRC de fibra de vidro-AR e núcleo de espuma de poliestireno expandido através de ensaios de flexão a quatro pontos, obtendo força máxima de 8,6 kN, com múltipla fissuração observada em todos os corpos de prova.

\section{- Modo de Ruptura}

Os corpos de prova de painéis sanduíches chegaram à ruptura pela formação de fissuras de cisalhamento no núcleo, que se propagaram dos pontos de aplicação de força até os suportes e laterais do material, como exposto na Figura 5-18-a. As fissuras demonstradas nessa figura podem ser comparadas ao efeito de pino observado no concreto armado, no qual a armadura atua como pinos de ligação nas fissuras, auxiliando na transferência da força cortante para o concreto e contribuindo para a resistência do elemento (CHAVEZ ARAUZ, 2002). Contudo, 
tal efeito pode ocasionar fissuras horizontais nesse processo, como observado no corpo de prova.

O aprofundamento de tais fraturas levou ao parcial descolamento entre núcleo e lâmina, próximo aos pontos de apoio, como demonstra a Figura 5-18-b. A exposição dessa região de interface entre os elementos decorre de seu caráter descontínuo de transição de materiais, tornando-a uma área frágil e suscetível a fraturas. Nota-se certa delaminação entre a matriz e o reforço nos pontos mais afetados dos compósitos laminares (Figura 5-18-c), levando à propagação das fissuras ao longo da largura do compósito.

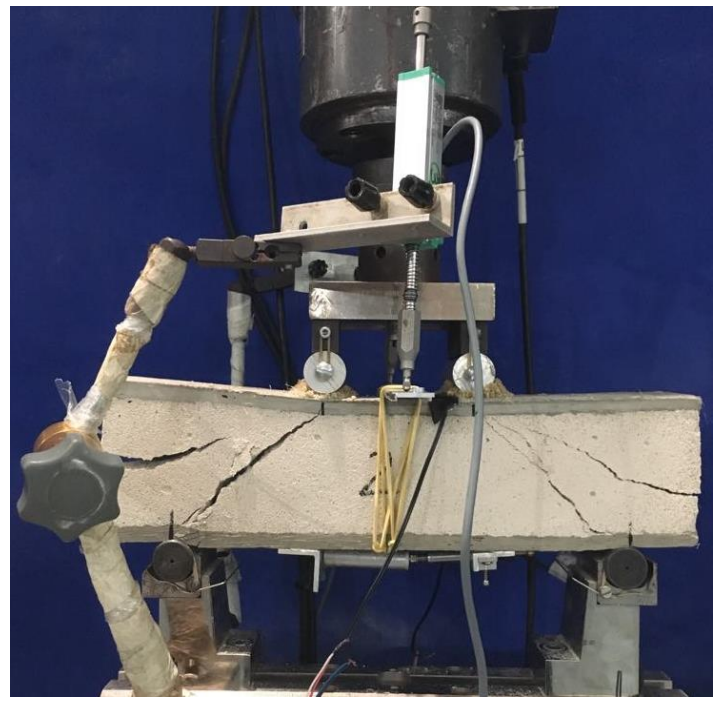

a)

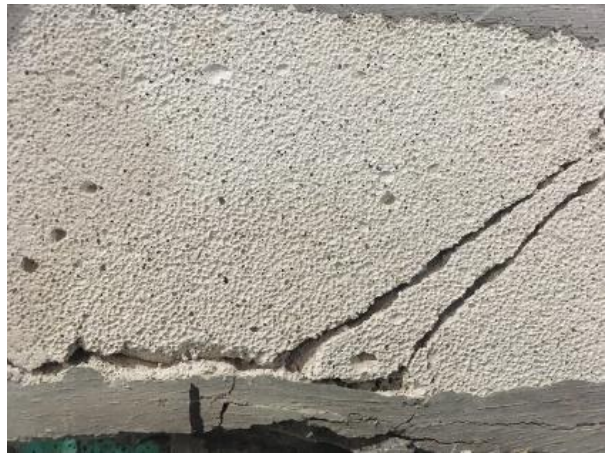

b)

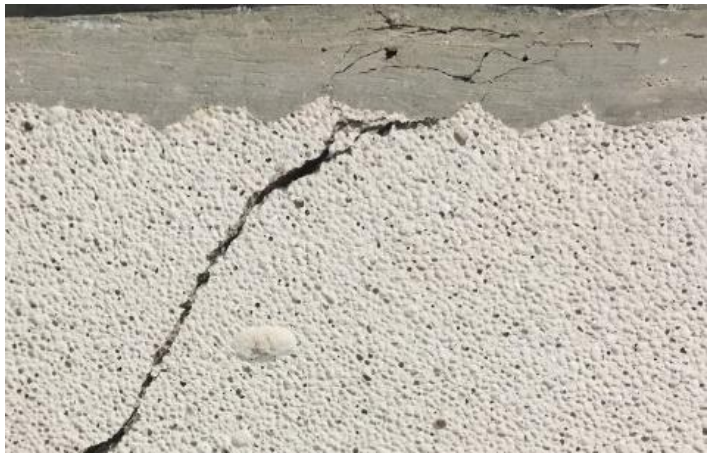

C)

Figura 5-18: Modos de ruptura do painel sanduíche: a) visão geral das fissuras no fim do ensaio, com fissuras de cisalhamento predominantes; b) detalhe do descolamento entre lâmina e núcleo, o qual pode ser associado ao efeito de pino; c) delaminação observada nos compósitos laminares 


\subsubsection{Núcleo}

\section{- Resistência ao Cisalhamento e Módulo de Cisalhamento}

Dentre as propriedades mais relevantes do núcleo, quando submetido à flexão, está a sua capacidade de transferir os esforços de cisalhamento por meio de uma aderência adequada com as lâminas, de maneira que é o elemento que oferece maior rigidez ao cisalhamento em um painel sanduíche. No entanto, o desempenho do núcleo deve ser suficientemente satisfatório para que as deformações de cisalhamento não atinjam uma magnitude que prejudicaria as vantagens adquiridas pela rigidez à flexão do painel (FOLIE, 1971). Para avaliar tal propriedade, calcula-se o módulo de cisalhamento, o qual representa a razão entre a tensão e a distorção, sendo um indicativo de rigidez do material.

Há fatores associados aos corpos de prova, entretanto, que influenciam a sua capacidade de resistência ao cisalhamento, como a existência de descontinuidades, porosidade e geometria do material do núcleo. Em geral, as variações de densidade constituem a principal origem de diferenças de resultados entre amostras testadas (ASTM C393, 2011).

Uma vez que equações clássicas previamente demonstraram que o módulo de elasticidade do núcleo não pode ser desconsiderado no cálculo de rigidez (como expresso na (Eq. 5-3), a equação de Allen, (Eq. 2-7, será usada para o cálculo da resistência ao cisalhamento. O ponto em que a distribuição de tensões cisalhantes é maior ocorre no centroide, isto é, quando $\mathrm{z}=0$. Ademais, a força de corte para um ensaio de flexão a quatro pontos é de $\mathrm{P} / 2$. Nesse caso, a Eq. 2-7 transforma-se em:

$$
\tau=\frac{P \max }{2 D}\left[E_{f} \frac{t d_{c}}{2}+\frac{c^{2} E_{c}}{8}\right]
$$

Onde:

$\tau=$ resistência ao cisalhamento $(\mathrm{MPa})$;

Pmax = força máxima aplicada $(\mathrm{N})$

$\mathrm{D}=$ rigidez à flexão $\left(\mathrm{N} \cdot \mathrm{mm}^{2}\right)$;

$\mathrm{E}_{\mathrm{f}}=$ módulo de elasticidade das lâminas $\left(\mathrm{N} / \mathrm{mm}^{2}\right)$;

$\mathrm{E}_{\mathrm{c}}=$ módulo de elasticidade do núcleo $\left(\mathrm{N} / \mathrm{mm}^{2}\right)$;

$\mathrm{t}=$ espessura média das lâminas $(\mathrm{mm})$; 
$\mathrm{d}_{\mathrm{c}}=$ distância entre os centróides da lâmina $(\mathrm{mm})$;

$\mathrm{c}=$ espessura do núcleo $(\mathrm{mm})$;

Tem-se que os valores médios de resistência ao cisalhamento, levando-se em conta o valor de rigidez à flexão anteriormente calculado, encontram-se resumidos na tabela a seguir:

Tabela 5-6: Dimensões de cálculo e resultados médios da resistência ao cisalhamento do núcleo

\begin{tabular}{ccccccc}
\hline Painel & Pmax $(\mathbf{N})$ & $\mathbf{t}_{\text {médio }}(\mathbf{m m})$ & $\mathbf{c}(\mathbf{m m})$ & $\mathbf{d c}(\mathbf{m m})$ & $\mathbf{D}\left(\mathbf{N} \cdot \mathbf{m m}^{\mathbf{2}}\right)$ & $\boldsymbol{\tau}_{\max }(\mathbf{M P a})$ \\
\hline 1 & 4238 & 10,6 & 68,7 & 79,3 & $5,69 \mathrm{E}+10$ & 0,45 \\
2 & 4055 & 10,6 & 69,5 & 80,1 & $5,84 \mathrm{E}+10$ & 0,43 \\
3 & 3732 & 10,8 & 68,3 & 79,1 & $5,70 \mathrm{E}+10$ & 0,40 \\
Média & $\mathbf{4 0 0 8}$ & $\mathbf{1 0 , 6}$ & $\mathbf{6 8 , 8}$ & $\mathbf{7 9 , 5}$ & $\mathbf{5 , 7 4 E}+\mathbf{1 0}$ & $\mathbf{0 , 4 3}$ \\
Desvio Padrão & $\mathbf{2 5 6}$ & $\mathbf{0 , 1 0}$ & $\mathbf{0 , 6 0}$ & $\mathbf{0 , 5 4}$ & $\mathbf{8 , 2 2 E + 0 8}$ & $\mathbf{0 , 0 3}$ \\
\hline
\end{tabular}

Tendo-se em vista que o concreto celular autoclavado é um material isotrópico, o módulo de cisalhamento do núcleo pode ser encontrado a partir da equação clássica que o correlaciona ao módulo de elasticidade e ao coeficiente de Poisson do material:

$$
G=\frac{E}{2(1+v)}
$$

Onde:

$\mathrm{G}=$ módulo de cisalhamento do núcleo $(\mathrm{GPa})$;

$\mathrm{E}=$ módulo de elasticidade $(\mathrm{GPa})$;

$v=$ coeficiente de Poisson;

Conforme calculado anteriormente, o módulo de elasticidade do núcleo é de $\mathrm{E}_{\mathrm{c}}=1,49$ GPa. O coeficiente de Poisson, por sua vez, foi fornecido pelo fabricante dos blocos de CCA e explicitado na Tabela 3-4, constituindo um valor entre 0,15 e 0,25. De maneira a utilizá-lo na fórmula, o valor médio de $v=0,20$ foi adotado. Tem-se:

$$
G=\frac{1,5}{2(1+0,2)}=0,63 G P a
$$

Tem-se que o valor médio de módulo de cisalhamento do núcleo é de 0,63 GPa. 


\section{- Modo de Ruptura}

De forma a melhor caracterizar o comportamento do núcleo, é importante ressaltar as diferenças do bloco de CCA quando ensaiado à flexão como elemento isolado ou inserido no painel sanduíche. No primeiro caso, o CCA apresenta uma ruptura frágil, caracterizada por uma fissura no meio do vão ou próxima aos roletes de aplicação de carga. Quando utilizado como núcleo e auxiliado pelas camadas de compósitos laminares em suas extremidades, é possível notar fissuras diagonais e um comportamento mais dúctil.

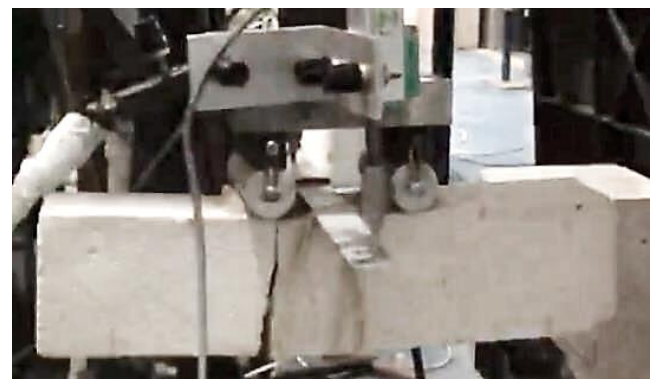

a)

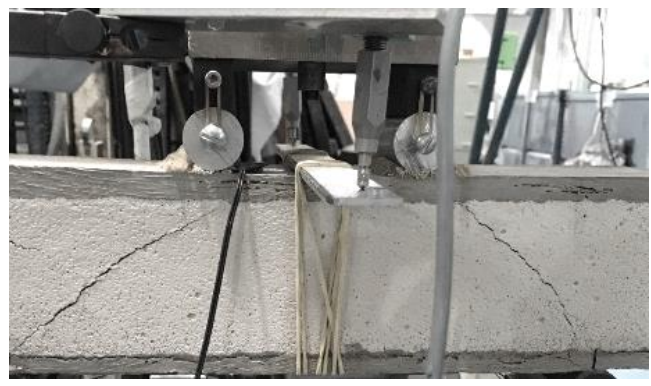

b)

Figura 5-19: Comparativo do comportamento de flexão do CCA: a) como bloco, apresentando fissura única; b) entre as lâminas do painel sanduíche, apresentando fissuras de cisalhamento

Pode-se estender tal comparação às curvas de força-deflexão obtidas pelo bloco isolado de CCA e pelo painel sanduíche, expressa na Figura 5-20, a qual demonstra o comportamento de ambos por uma envoltória das curvas respectivas. Os ganhos, portanto, não apenas na resistência à flexão, mas igualmente na capacidade de absorção de energia, são notáveis.

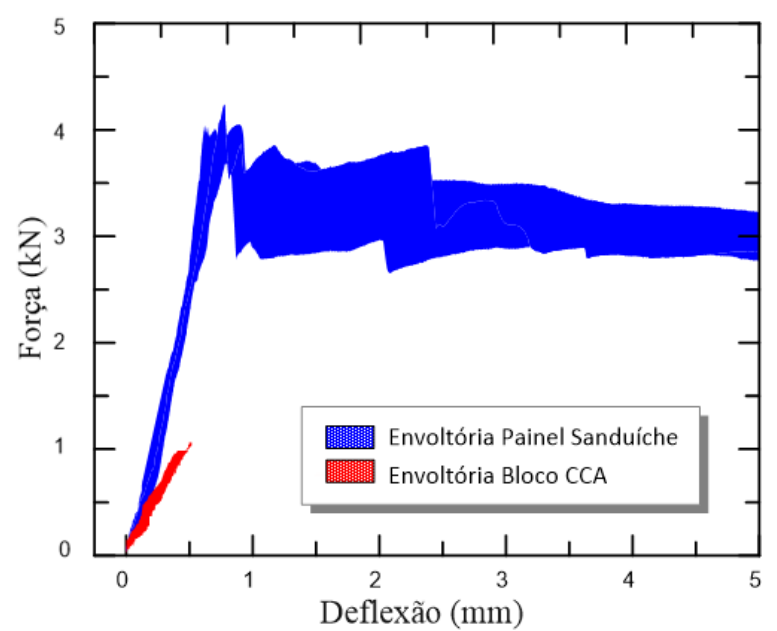

Figura 5-20: Relação força-deflexão de todos os corpo de provas de painéis sanduíche e blocos de CCA submetidos à flexão a quatro pontos 
Comparativamente, o painel sanduíche apresenta uma tenacidade 7 vezes maior que o CCA no ponto de carga máxima. Um comportamento semelhante foi obtido pelo estudo de Dey (2015), no qual as estruturas sanduíche apresentaram uma capacidade de absorção de energia na faixa de 3 a 6 vezes maior do que o núcleo isolado de concreto celular.

\subsubsection{Lâminas}

\section{- Resistência à Tração e à Compressão}

Há inúmeros elementos que podem influenciar a resistência oferecida pelas lâminas de um painel sanduíche, dentre eles: os materiais das mesmas e do núcleo, os métodos de fabricação e cura, o material de aderência, a taxa de velocidade do ensaio, entre outros. Dentre os fatores especificamente associados à geometria dos corpos de prova, estão inclusos: a forma do núcleo, a espessura das lâminas e o nivelamento de sua superfície. Uma vez que a fabricação de cada lâmina foi feita em dias separados e com espessuras variáveis (dependentes do processo de moldagem), a Tabela 5-7 indica as espessuras das lâminas superior $\left(\mathrm{t}_{1}\right)$ e inferior $\left(\mathrm{t}_{2}\right)$, e calcula as resistência de acordo.

Para avaliar a propriedade de resistência aos esforços de compressão e de tração, a norma ASTM D7249 (2006) foi utilizada para o cálculo da resistência última de cada lâmina, individualmente. As fórmulas a seguir são válidas no regime linear, na pré-fissuração, para painéis sanduíche que se encaixam na condição de $t / c \leq 0,10$ - a qual os corpos de prova satisfazem:

$$
F_{1}^{u}=\frac{P_{\text {max }} *(S-L)}{2\left(d_{t}+c\right) b t_{1}} \quad F_{2}^{u}=\frac{P_{\text {max }} *(S-L)}{2\left(d_{t}+c\right) b t_{2}}
$$

Onde:

$F_{1}^{u}=$ tensão última da lâmina superior (MPa);

$F_{2}^{u}=$ tensão última da lâmina inferior (MPa);

Pmax = força máxima antes da ruptura $(\mathrm{N})$;

$\mathrm{S}=$ comprimento do vão total (mm);

$\mathrm{L}=$ vão entre os pontos de aplicação de força $(\mathrm{mm})$

$t_{1}=$ espessura da lâmina superior $(\mathrm{mm})$; 
$t_{2}=$ espessura da lâmina inferior $(\mathrm{mm})$;

$d_{t}=$ altura total do painel $(\mathrm{mm})$;

$\mathrm{c}=$ espessura do núcleo $(\mathrm{mm})$;

$\mathrm{b}=$ largura da viga $(\mathrm{mm})$;

Tabela 5-7: Dimensões de cálculo e resultados médios das resistências à compressão (lâmina superior, $\mathrm{F}_{1}$ ) e à tração (lâmina inferior, $\mathrm{F}_{2}$ )

\begin{tabular}{ccccccccc}
\hline Painel & $\begin{array}{c}\text { Pmax } \\
(\mathbf{N})\end{array}$ & $\begin{array}{c}\mathbf{d t} \\
(\mathbf{m m})\end{array}$ & $\begin{array}{c}\mathbf{c} \\
(\mathbf{m m})\end{array}$ & $\begin{array}{c}\mathbf{b} \\
(\mathbf{m m})\end{array}$ & $\begin{array}{c}\mathbf{t}_{1} \\
(\mathbf{m m})\end{array}$ & $\begin{array}{c}\mathbf{t}_{2} \\
(\mathbf{m m})\end{array}$ & $\begin{array}{c}\mathbf{F}_{1} \\
(\mathbf{M P a})\end{array}$ & $\begin{array}{c}\mathbf{F}_{2} \\
(\mathbf{M P a})\end{array}$ \\
\hline 1 & 4238 & 89,8 & 68,7 & 61 & 9,8 & 11,3 & 4,01 & 3,48 \\
2 & 4055 & 90,7 & 69,5 & 61,25 & 9,8 & 11,3 & 3,78 & 3,28 \\
3 & 3732 & 89,8 & 68,3 & 60,5 & 8,8 & 12,7 & 3,97 & 2,77 \\
Média & $\mathbf{4 0 0 8}$ & $\mathbf{9 0 , 1}$ & $\mathbf{6 8 , 8}$ & $\mathbf{6 0 , 9}$ & $\mathbf{9 , 5}$ & $\mathbf{1 1 , 8}$ & $\mathbf{3 , 9 2}$ & $\mathbf{3 , 1 8}$ \\
Desvio & $\mathbf{2 5 6}$ & $\mathbf{0 , 4 8}$ & $\mathbf{0 , 6 0}$ & $\mathbf{0 , 3 8}$ & $\mathbf{0 , 5 8}$ & $\mathbf{0 , 7 7}$ & $\mathbf{0 , 1 2}$ & $\mathbf{0 , 3 7}$ \\
Padrão & & & & & & & & \\
\hline
\end{tabular}

\section{- Modo de Ruptura}

As lâminas superiores e inferiores dos painéis apresentaram fissuras transversais originárias da propagação de fissuras de cisalhamento no núcleo, apresentando igualmente o efeito de pino, como demonstra a Figura 5-21-a. As lâminas superiores apresentaram fissuras menos pronunciadas que as inferiores, concentradas na área próxima aos roletes de aplicação de força (Figura 5-21-b). Entretanto, tais lâminas, submetidas aos esforços de compressão, exibiram uma maior área de descolamento entre os compósitos e o CCA, o que diminuiu a sua aderência com o núcleo.

As lâminas inferiores, por sua vez, apesentaram maior propagação de fissuras na matriz, localizadas na área correspondente aos roletes de apoio (Figura 5-21-d). Ambas as lâminas apresentaram zonas de delaminação, indicando que a interface matriz-fibras foi degradada (Figura 5-21-c). 


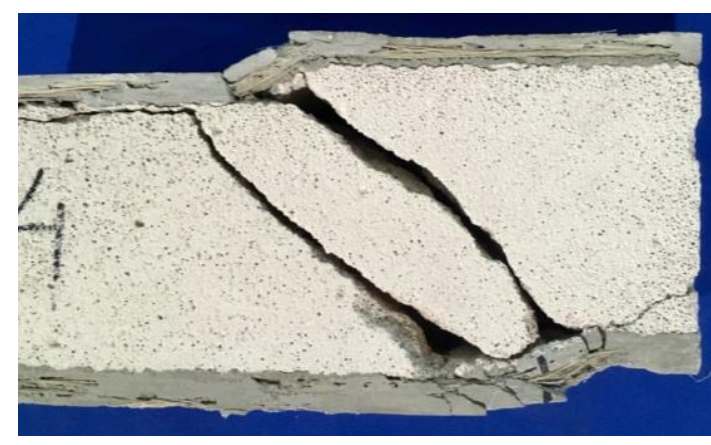

a)

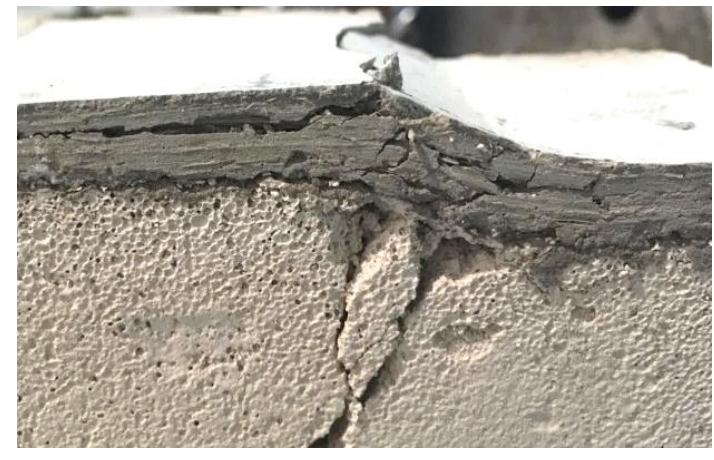

c)

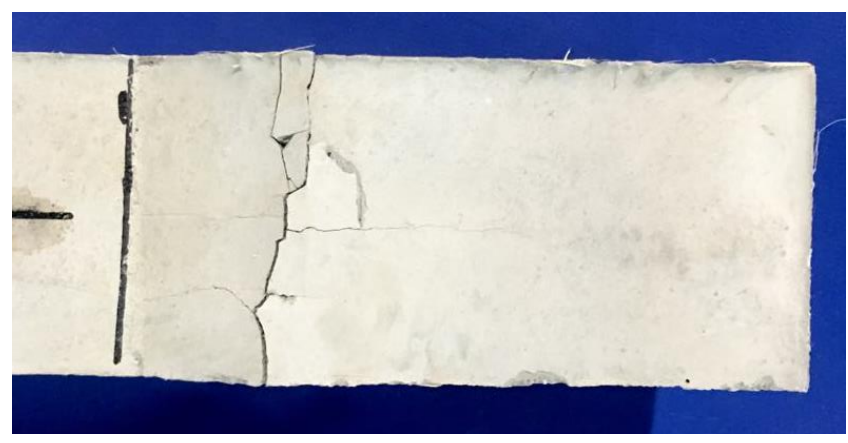

b)

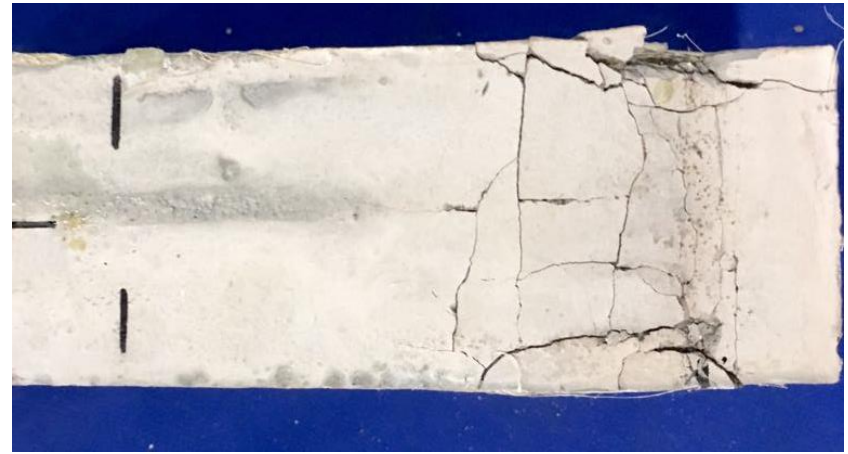

d)

Figura 5-21: : Modo de ruptura das lâminas do painel sanduíche: a) fissuras de cisalhamento no núcleo são responsáveis pela ruptura da estrutura, suscitando descolamento em relação às lâminas e gerando tensões interlaminares; b) vista da lâmina superior do painel, com uma fissura transversal principal; c) delaminação observada nas lâminas superior e inferior; d) vista da lâmina inferior do painel, com a propagação de fissuras e dano pronunciado na matriz

\subsubsection{Ensaio Cíclico de Flexão a Quatro Pontos}

Os resultados obtidos pela aplicação de 10 ciclos de carregamento-descarregamento em três corpos de prova de painéis sanduíche podem ser ilustrados pela curva típica do ensaio, apresentada na Figura 5-22, a qual indica as diferenças de comportamento em relação ao ensaio monotônico.

Uma vez que as amostras foram ensaiadas sem entalhe, as equações padrão de mecânica da fratura não foram utilizadas para a análise do material. Entretanto, análises relativas à rigidez e à energia foram executadas para cada corpo de prova, atuando como parâmetros representativos da degradação da estrutura durante o processo. 


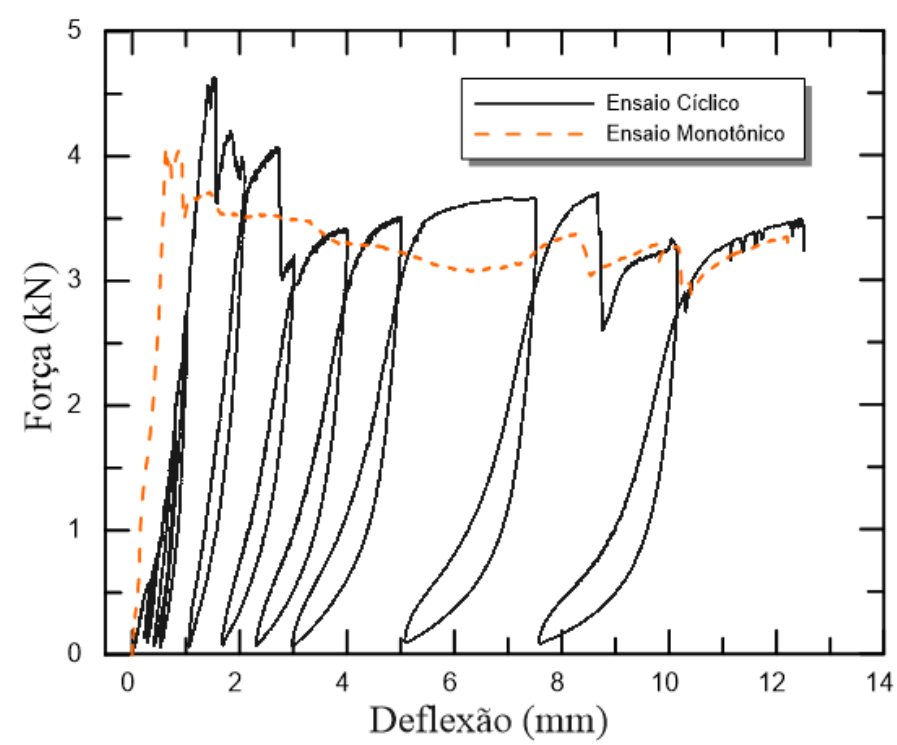

Figura 5-22: Relação força-deflexão comparativa entre o comportamento sob flexão a quatro pontos em ensaios monotônico e cíclico

O comportamento dos corpos de prova sob ensaios cíclicos mostrou-se similar ao monotônico, demonstrando considerável capacidade de resistência e, apesar da perda de rigidez inicial, um maior valor de $\mathrm{P}_{\max }$. Curvas de histerese características foram obtidas, mudando de forma e se tornando mais largas conforme o aumento do número de ciclos. De acordo com Rouby e Reynaud (1993), a degradação da interface entre matriz-fibras leva a uma maior possibilidade de ruptura e uma ampliação da forma dos ciclos, sendo um indicativo de perda de rigidez. Ademais, nota-se que ciclos originados em maiores valores de deflexão apresentam deformações inelásticas - como é possível notar ao compará-los aos ciclos iniciais (Figura $5-25)$.

Nota-se também que, no processo de descarregamento, há um deslocamento residual que precede o carregamento de um novo ciclo. Tal deslocamento está associado à capacidade do material de se recuperar dos danos advindos dos ciclos impostos - de forma que o acúmulo de ciclos leva a valores maiores de deslocamento. Para avaliar esse parâmetro, calcula-se o grau de reversibilidade, definido como a razão entre o deslocamento reversível ( $\delta r)$ e o deslocamento total $(\delta \mathrm{t})$ do ciclo de histerese. $\mathrm{O}$ deslocamento total é definido como a distância em $\mathrm{x}$ até o ponto de descarregamento do ciclo (BOULEKBACHE et al., 2014).

O módulo dos ciclos é outra forma de analisar o comportamento à flexão dos corpos de prova sob carregamento cíclico. O cálculo de $\mathrm{E}_{\text {cicl }}$ é baseado na inclinação da linha que conecta os dois pontos de reversão do carregamento. A inclinação do início elástico da curva força- 
deflexão é calculada por meio de $\mathrm{E}_{0}$, o qual representa o módulo tangencial inicial (BOULEKBACHE et al., 2016).

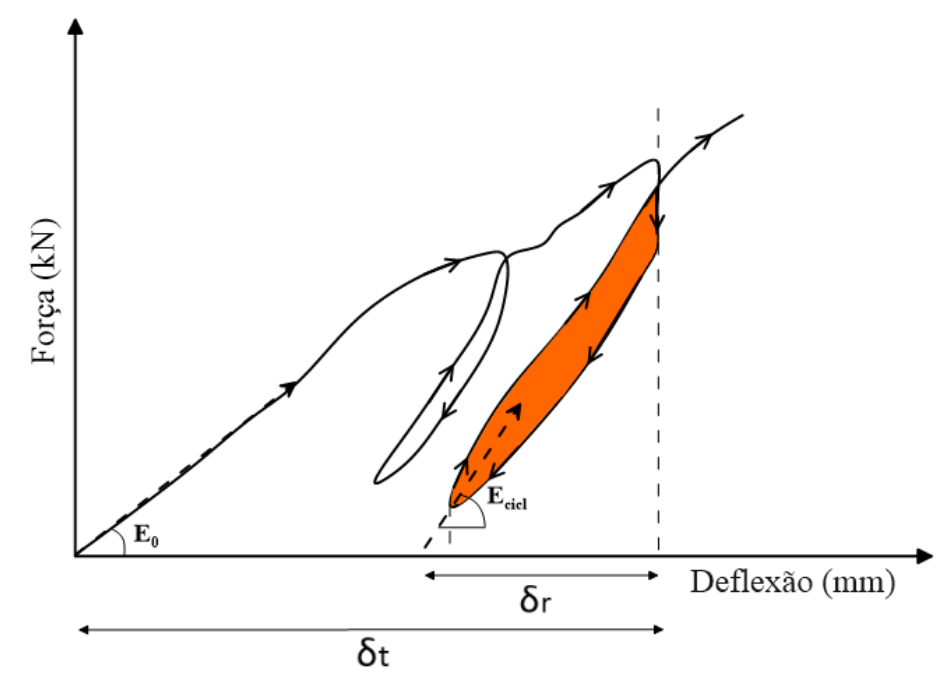

Figura 5-23: Curva força vs deflexão dos primeiros ciclos de carregamento-descarregamento e parâmetros de análise: $\delta$ r é o deslocamento reversível, $\delta$ t é o deslocamento total, $\mathrm{E}_{0}$ é a rigidez inicial do corpo de prova, $\mathrm{E}_{\mathrm{cicl}}$ é a rigidez associada ao ciclo analisado, e a área destacada é a energia dissipada no processo

A Figura 5-24 demonstra a relação típica entre o grau de reversibilidade e a deflexão normalizada dos corpos de provas. Essa última foi obtida a partir da razão $\delta / \delta_{\max }$, isto é, a deflexão obtida para determinada força, $\delta$, sobre a deflexão obtida na força máxima, $\delta$ max.

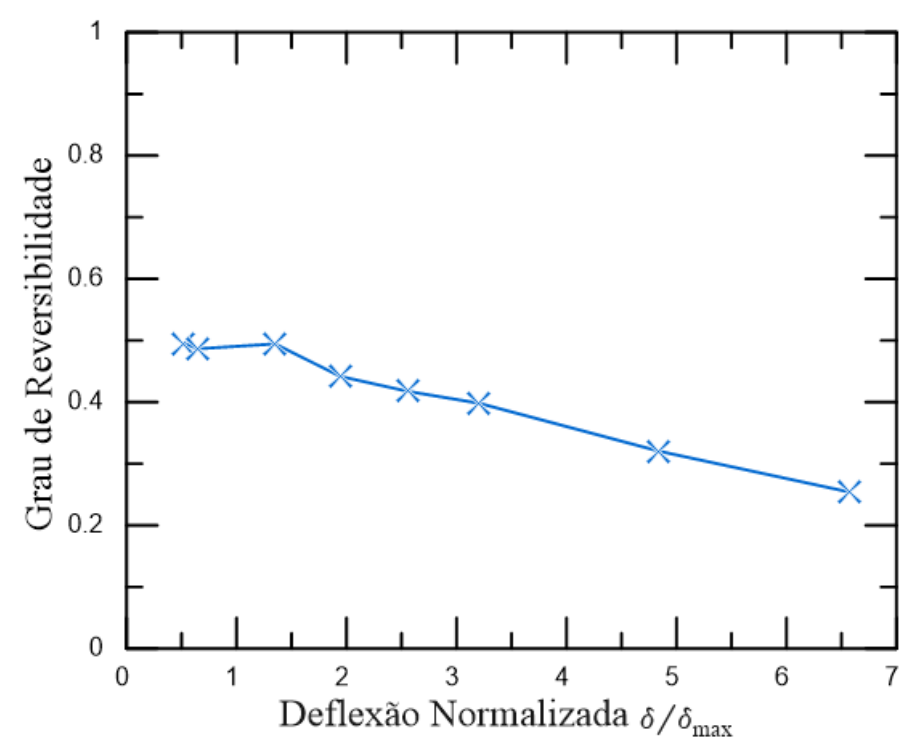

Figura 5-24: Relação entre o grau de reversibilidade, $\delta$ r/ $\delta$ t, e a deflexão normalizada, $\delta / \delta \max$ 
Nota-se que há uma tendência clara de decrescimento do grau de reversibilidade após o pico de força (quando $\delta / \delta \max =1$ ), uma vez que o material é desgastado e perde progressivamente sua capacidade de recuperação.

O grau de reversibilidade dos corpos de prova está igualmente relacionado à rigidez apresentada pelo material, uma vez que ambos são proporcionais: menores valores de rigidez implicam em menores graus de reversibilidade. Assim, pode-se avaliar o decrescimento gradativo da rigidez dos painéis a partir do coeficiente angular das curvas de carregamentodescarregamento dos corpos de prova para todos os seus 10 ciclos. A Figura 5-25 ilustra as retas de ligação entre os pontos de reversão de carregamento, as quais representam as inclinações utilizadas no cálculo de cada $\mathrm{E}_{\text {cicl. }}$ A rigidez inicial, $\mathrm{E}_{0}$, anterior ao primeiro ciclo, foi igualmente calculada.

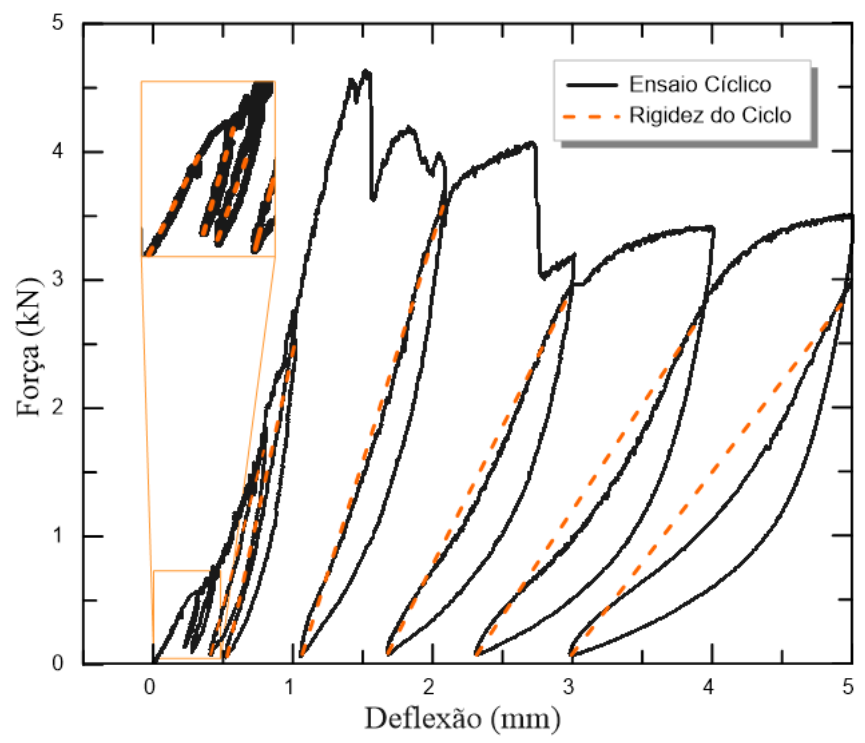

Figura 5-25: Representação das retas utilizadas para o cálculo do coeficiente angular dos ciclos de histerese, com detalhe para o comportamento dos ciclos iniciais, que apresentam maior rigidez

A Figura 5-26 demonstra a evolução do módulo (rigidez) normalizado dos ciclos ao longo dos pontos de deflexão correspondentes. A maior perda de rigidez ocorre nos ciclos iniciais, como é igualmente possível notar na área elástica das curvas dos ensaios monotônico e cíclico, Figura 5-22. Tem-se que a relação apresentada a seguir é representativa do estado do material após os danos sofridos em sua estrutura: 


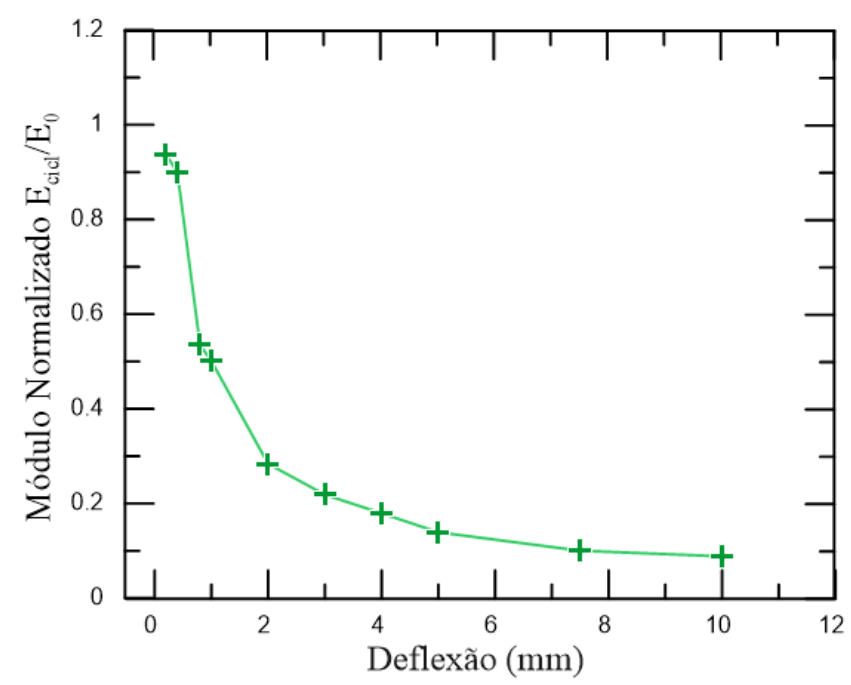

Figura 5-26: Relação típica entre o módulo normalizado dos ciclos e deflexão apresentada por esses

Uma vez que há o aumento da carga, as fissuras desenvolvem-se e se alargam com o andamento do ensaio, gerando transformações da curva durante o ato de carregamentodescarregamento, as quais não são inteiramente recuperáveis devido ao seu caráter inelástico. Os ciclos de histerese tornam-se cada vez mais largos, o que indica que há uma parcela significativa de energia sendo dissipada nesse processo (BOULEKBACHE et al., 2016; DUTKIEWICZ, 1999). Para calculá-la, é necessário obter a área entre os ciclos, como indicado anteriormente na Figura 5-23. O software OriginPro foi utilizado para obter a área englobada pelos ciclos de cada painel. A Figura 5-27 mostra o acúmulo de energia dissipada ao longo dos ciclos, utilizando como referência os pontos de deflexão de 1, 2, 3, 4, 5, 7,5 e $10 \mathrm{~mm}$, correspondentes aos pontos de descarregamentos dos ciclos 4 ao 10.

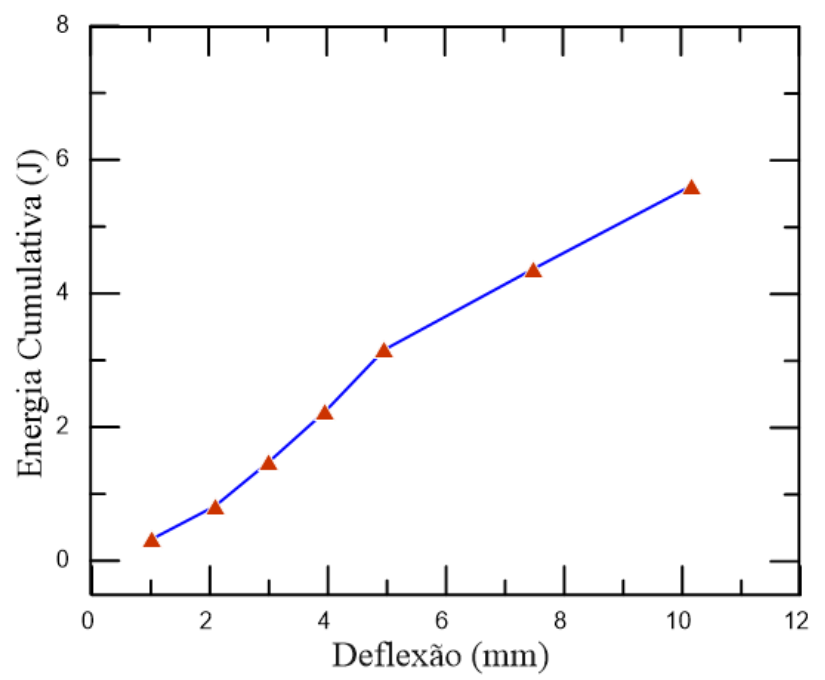

Figura 5-27: Relação típica entre a energia cumulativa dos ciclos de histerese, obtidos pela área entre as curvas de carregamento e descarregamento, e os pontos de deflexão dos corpo de provas 
A perda de energia total é calculada pela soma das áreas de todos os ciclos. É possível associar esse valor à tenacidade perdida durante um ensaio cíclico em comparação ao seu equivalente monotônico. Para correlacioná-los, calculou-se o valor médio de tenacidade em $\delta=12 \mathrm{~mm}$ para os corpos de prova submetidos à flexão monotônica, conforme consta na Tabela 5-3. Assim, somando-se as áreas médias dos ciclos, contabiliza-se 6,29 J, ao passo que a tenacidade média dos ensaios monotônicos perfaz 36,27 J. Logo, há uma perda média de $17,34 \%$ da tenacidade dos painéis após o processo de carregamento-descarregamento em 10 ciclos.

Em relação ao modo de ruptura, os corpos de prova testados apresentaram determinadas mudanças em seu comportamento à flexão quando os carregamentos cíclicos foram implementados aos ensaios. Verifica-se, através da Figura 5-28, que o núcleo de CCA apresentou maior propagação das fissuras e áreas particularmente danificadas. Nota-se também que as faces superiores, sob compressão, apresentaram danos muito inferiores às lâminas correspondentes dos corpos de prova testados em ensaios monotônicos. As lâminas inferiores apresentaram descolamento em relação ao núcleo, assim como vestígios de tensões interlaminares.

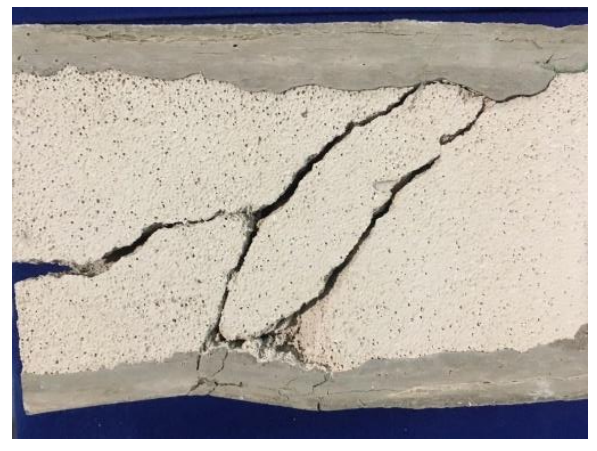

a)

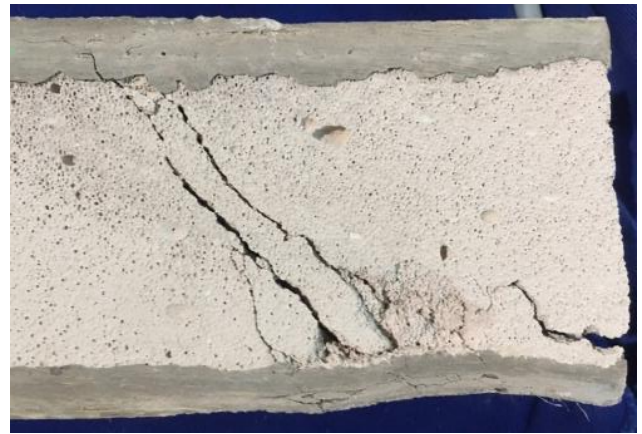

b)

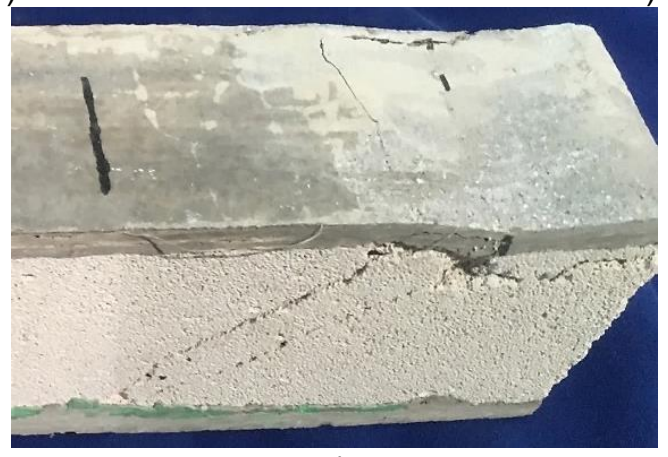

C)

Figura 5-28: Modos de ruptura dos corpos de prova ensaiados à flexão a quatro pontos sob carregamento cíclico:

a) multiplicação das fissuras no núcleo, com descolamento entre a lâmina inferior e o CCA; b) detalhe para o núcleo danificado e a lâmina inferior deformada com os esforços; c) lado inferior do painel, demonstrando a propagação das fissuras na região transversal 
De acordo com Cuypers (2002), painéis sanduíche com faces de TRC (textile reinforced concrete) não apresentam danos significativos nas lâminas de compressão, pois as mesmas se comportam de maneira linear-elástica; o lado submetido à tração, contudo, acumula os efeitos do carregamento repetido, apresentando degradação da interface matriz-fibras.

Tal como já explicitado anteriormente, os compósitos apresentam um mecanismo de fratura baseado na propagação e eventual alargamento das fissuras, as quais atravessam a seção transversal da matriz no processo. Após o ponto de saturação das fissuras, conforme Hegger et al.(2006) constataram no caso de carregamentos cíclicos, a interface entre matriz-fibra sofre desgaste mais intenso para cada carregamento adicional. Dessa forma, perde-se, gradualmente, a eficiência do mecanismo de transferência de tensões do compósito. Os corpos de prova, todavia, apresentaram um comportamento satisfatório, não demonstrando um nível de degradação crítico a ponto de iniciar o arrancamento das fibras da matriz.

\subsubsection{Conclusões}

No presente capítulo, investigaram-se as propriedades mecânicas e de aderência de painéis sanduíche com compósitos laminados reforçados com fibra de curauá e núcleo de concreto celular autoclavado. A avaliação da aderência entre as lâminas e o núcleo se deu por meio da análise de sua microestrutura e de ensaios de pull-off. As micrografias demonstraram que a transição entre os materiais não apresenta uma superfície rugosa e atua como um elemento único. Os ensaios de aderência exibiram modo de ruptura predominante por falha do compósito, área de maior fragilidade entre os elementos. As amostras apresentaram uma resistência à tração superior a 0,09 $\mathrm{MPa}$, o que corrobora a qualidade da aderência.

Ensaios de flexão a quatro pontos foram executados em três corpos de prova de $350 \mathrm{~mm}$ x $60 \mathrm{~mm}$ x $90 \mathrm{~mm}$. As amostras apresentaram zona elástico-linear até alcançarem uma força máxima de $4008 \mathrm{~N}$ e deflexão de $0,83 \mathrm{~mm}$. A partir desse ponto, o material apresentou comportamento de deflection softening, com o aparecimento de fissuras no núcleo e nas lâminas. Dentre os parâmetros mecânicos mais importantes, obteve-se: rigidez à flexão de 5,74 x $10^{10}$ N.mm ${ }^{2}$ e rigidez ao cisalhamento transversal de $2,29 \times 10^{5} \mathrm{~N}$ para os painéis; para o núcleo, resistência ao cisalhamento de 0,43 MPa e módulo de cisalhamento de 0,63 GPa; para as lâminas, resistência à compressão e à tração de 3,92 MPa e 3,18 MPa, respectivamente.

Ensaios de flexão com carregamento cíclico foram igualmente implementados. O comportamento típico dos corpos de prova exibiu ciclos de histerese característicos, que se 
alargaram progressivamente, demonstrando a contínua degradação do material. Comparativamente ao ensaio monotônico, os corpos de prova perderam $17,34 \%$ de sua tenacidade aos $12 \mathrm{~mm}$ de deflexão. Os painéis sanduíche, entretanto, demonstraram ductilidade satisfatória no pós-pico, de forma que a energia não foi perdida de forma abrupta, mas liberada gradualmente ao longo de seu comportamento de deflection-softening. O modo de ruptura predominante nos ensaios monotônicos e cíclicos consistiu em fissuras de cisalhamento no núcleo e fraturas transversais nas lâminas, particularmente nas inferiores, sujeitas a esforços de tração. 


\section{Conclusões e Trabalhos Futuros}

\subsection{Conclusões}

A matriz empregue na produção de compósitos cimentícios demonstrou consistência e resistência à compressão adequadas para a sua aplicação, apresentando comportamento satisfatório com uma composição baseada na substituição parcial do cimento por materiais pozolânicos. As fibras de curauá provaram-se uma escolha apropriada para o reforço de tais compósitos, exibindo considerável resistência à tração, de valor equiparável a fibras sintéticas. O alinhamento unidirecional do tecido de curauá, aliado a uma interface fibra-matriz satisfatória, proporcionou ganhos de resistência e tenacidade no comportamento pós-fissuração dos compósitos. Todos os corpos de provas apresentaram múltipla fissuração, com strain/deflection hardening nos ensaios de tração direta e flexão a quatro pontos, respectivamente.

O núcleo de concreto celular autoclavado (CCA), de baixa resistência à compressão e ruptura frágil, apresentou maior ductilidade quando auxiliado pelos compósitos laminares na estrutura sanduíche. A superfície rugosa e porosa do CCA facilitou a adesão com os compósitos cimentícios, cuja matriz fluida incorporou-se de modo ideal ao núcleo, proporcionando uma interface suave de transição de materiais. Ensaios de aderência e análises de micrografias corroboraram a qualidade da aderência entre lâminas e núcleo.

Os painéis sanduíche, fundamentados numa estrutura de lâminas reforçadas com tecido de curauá e núcleo espesso de CCA, evidenciaram aprimoramentos na relação de rigidez à flexão e absorção de energia. A capacidade de carga alcançada pelos corpos de prova mostrouse igual ou superior a painéis sanduíche de estrutura similar. O comportamento de deflection softening exibido pelos painéis sob flexão demonstrou ductilidade satisfatória e permitiu a dissipação gradual de energia. Os painéis demonstraram bom desempenho quando submetidos a carregamentos cíclicos, manifestando um comportamento de compósito entre os seus três elementos constituintes principais, cujas propriedades complementaram-se no processo. Em geral, os painéis sanduíche apresentaram aderência apropriada entre lâminas e núcleo, tal como 
resposta mecânica favorável a uma possível aplicação como material leve e sustentável para construções de baixo custo.

\subsection{Sugestões para Trabalhos Futuros}

Haja vista a necessidade de investigar e aprofundar determinados temas englobados por essa pesquisa, algumas sugestões são propostas a seguir:

- Realizar o ensaio de pull-out do cordão a partir do tecido da fibra;

- Comparar o comportamento mecânico de painéis com variações na fração volumétrica das fibras;

- Comparar o desempenho de painéis sanduíche com um núcleo de concreto espumoso;

- Realizar o ensaio de flexão a quatro pontos com entalhe nos ensaios monotônicos e cíclicos, de maneira a avaliar a abertura de fissuras e investigar os mecanismos de fratura;

- Realizar ensaios com outros comprimentos de vão e analisar como os modos de ruptura serão afetados;

- Realizar ensaios de pull-off com lâminas sem o reforço fibroso;

- Realizar análises por correlação digital de imagens (Digital Image Correlation, DIC); -Investigar meios alternativos de aderência entre as lâminas e o núcleo;

-Estudar a durabilidade dos painéis a longo prazo. 


\section{Referências bibliográficas}

AGARWAL, B. D.; BROUTMAN, L.J.; CHANDRASHEKHARA, K. Analysis and performance of fiber composites. New York, John Wiley \& Sons, 2017.

ALEXANDERSON, J. Relations between structure and mechanical properties of autoclaved aerated concrete. Cement and Concrete Research, v. 9, n. 4, p. 507-514, 1979.

ALLEN, H. D. Analysis and Design of Structural Sandwich Panels. Oxford, Pergamon Press, 1969.

ALMEIDA, M. I. A. Comportamento estrutural de painéis sanduíche compósitos para aplicações na indústria da construção Engenharia Civil. Lisboa, 2009. 185p. Dissertação (mestrado). Faculdade de Engenharia Civil, Instituto Superior Técnico.

ALVES FIDELIS, M. E. et al. The effect of fiber morphology on the tensile strength of natural fibers. Journal of Materials Research and Technology, v. 2, n. 2, p. 149-157, 2013.

AMERICAN SOCIETY FOR TESTING AND MATERIALS. ASTM C230: Standard Specification for Flow Table for Use in Tests of Hydraulic Cement. United States, ASTM International, 2014.

AMERICAN SOCIETY FOR TESTING AND MATERIALS. ASTM C393: Standard Test Method for Core Shear Properties of Sandwich Constructions by Beam. United States, ASTM International, 2011.

AMERICAN SOCIETY FOR TESTING AND MATERIALS. ASTM C1341: Standard Test Method for Flexural Properties of Continuous Fiber-Reinforced Advanced Ceramic Composites. United States, ASTM International, 2013.

AMERICAN SOCIETY FOR TESTING AND MATERIALS. ASTM C1557: Standard Test Method for Tensile Strength and Young's Modulus of Fibers. United States, ASTM International, 2014.

AMERICAN SOCIETY FOR TESTING AND MATERIALS. ASTM C-1693: Standard Specification for Autoclaved Aerated Concrete (AAC). United States, ASTM International, 2009.

AMERICAN SOCIETY FOR TESTING AND MATERIALS. ASTM D7249: Standard Test Method for Facing Properties of Sandwich Constructions by Long Beam Flexure. United States, ASTM International, 2006.

AMERICAN SOCIETY FOR TESTING AND MATERIALS. ASTM D7250: Standard Practice for Determining Sandwich Beam Flexural and Shear Stiffness. United States, ASTM International, 2009. 
AMRAN, Y. H. M.; FARZADNIA, N.; ALI, A. A. A. Properties and applications of foamed concrete; A review. Construction and Building Materials, v. 101, p. 990-1005, 2015.

ANDRADE, A. G. C. et al. Potencialidades e usos do curauá em plantios florestais. 1.ed. Belém, Universidade Federal Rural da Amazônia, 2011, 30p.

ARBAOUI, J. et al. Comparison Study and Mechanical Characterisation of a Several Composite Sandwich Structures. International Journal of Composite Materials, v. 5, n. 1, p. $1-8,2015$.

ASSOCIAÇÃO BRASILEIRA DE NORMAS TÉCNICAS. NBR 12653: Materiais pozolânicos - Requisitos. Rio de Janeiro, 2012.

ASSOCIAÇÃO BRASILEIRA DE NORMAS TÉCNICAS. NBR 13528: Revestimento de paredes de argamassas inorgânicas - Determinação da resistência de aderência à tração. Rio de Janeiro, 2010.

ASSOCIAÇÃO BRASILEIRA DE NORMAS TÉCNICAS. NBR 5733: Cimento Portland de alta resistência inicial. Rio de Janeiro, 1991.

BALEY, C. Analysis of the flax fibres tensile behaviour and analysis of the tensile stiffness increase. Composites - Part A: Applied Science and Manufacturing, v. 33, n. 7, p. 939-948, 2002.

BENÍTEZ-GUERRERO, M. et al. Comparison of thermal behavior of natural and hot-washed sisal fibers based on their main components: Cellulose, xylan and lignin. TG-FTIR analysis of volatile products. Thermochimica Acta, v. 581, p.70-86, 2014.

BENTUR, A.; MINDESS, S. Fibre Reinforced Cementitious Composites. 2.ed, London, Taylor \& Francis, 1990.

BIAGIOTTI, J.; PUGLIA, D.; KENNY, J. M. A Review on Natural Fibre-Based CompositesPart I. Journal of Natural Fibers, v.1, n. 2, p. 37-68, 2004.

BLEDZKI, A. K.; GASSAN, J. Composites reinforced with cellulose based fibres. Progress in Polymer Science, v. 24, n. 2, p. 221-274, 1999.

BONAKDAR, A.; BABBITT, F.; MOBASHER, B. Physical and mechanical characterization of Fiber-Reinforced Aerated Concrete (FRAC). Cement and Concrete Composites, v. 38, p. 82-91, 2013.

BOULEKBACHE, B. et al. Comportement en flexion des bétons fibrés sous chargement cyclique. MATEC Web of Conferences. EDP Sciences, 2014.

BOULEKBACHE, B. et al. Flexural behaviour of steel fibre-reinforced concrete under cyclic loading. Construction and Building Materials, v. 126, p. 253-262, 2016.

BRITISH STANDARDS. BS EN 1351: Determination of flexural strength of autoclaved aerated concrete. London, British-Adopted European Standard, 1997.

BRUFFEY, N.; SHIU, W. Predicting Flexural Strength of Composite Honeycomb Core 
Sandwich Panels Using Mechanical Models of Face Sheet Compressive Strength. California, 2016. 38p. Dissertation (Bachelor of Science). California Polytechnic State University.

BRÜHWILER, E.; WANG, J.; WITTMANN, F. H. Fracture of AAC as Influenced by Specimen Dimension and Moisture. Journal of Materials in Civil Engineering, v. 2, n. 3, p. 136-146, 2007.

CABRILLAC, R. et al. Experimental study of the mechanical anisotropy of aerated concretes and of the adjustment parameters of the introduced porosity. Construction and Building Materials, v. 20, n. 5, p. 286-295, 2006.

CANOVAS, M. F.; SELVA, N. H.; KAWICHE, G. M. New economical solutions for improvement of durability of Portland cement mortars reinforced with sisal fibres. Materials and Structures, v. 25, n. 7, p. 417-422, 1992.

CHANDRAMOHAN, D. .; MARIMUTHU, K. A review on natural fibers. International Journal of Research and Reviews in Applied Sciences, v. 8, n. 2, p. 194-206, 2011.

CHAVEZ ARAUZ, A. Resistencia ao cisalhamento de vigas em concreto armado reforçado com fibras de aço. São Paulo, 2002. 135p. Dissertação (mestrado) - Faculdade de Engenharia Civil, Universidade Estadual de Campinas.

CHEN, Y. et al. Mechanical Properties of Autoclaved Aerated Concrete with Different Densities. Advances in Civil Engineering Materials, v. 2, n. 1, p. 441-456, 2013

COLOMBO, I. G.; COLOMBO, M.; DI PRISCO, M. Bending behaviour of Textile Reinforced Concrete sandwich beams. Construction and Building Materials, v. 95, p. 675-685, 2015.

CONNAN, H. G. et al. Autoclaved OPC-quartz blends incorporating clay-brick waste. Part I: factorial design effects on strength development. Advances in Cement Research, v. 17, n. 4, p. 133-141, 2005.

COSTA CORREIA, V.; SANTOS, S. F.; SAVASTANO, H. Vegetable fiber as reinforcing elements for cement based composite in housing applications - a Brazilian experience. In: MATEC Web of Conferences. EDP Sciences, 2018

CUYPERS, H. Analysis and design of sandwich panels with brittle matrix composite faces for building applications. Brussels, 2002. Thesis (PhD). Vrije Universiteit Brussel.

CUYPERS, H.; WASTIELS, J. Analysis and verification of the performance of sandwich panels with textile reinforced concrete faces. Journal of Sandwich Structures and Materials, v. 13, n. 5, p. 589-603, 2011.

CWPERS, H.; VAN ITTERBEECK, P.; WASTIELS, J. The Effect of Durability on the Design of Self-Bearing Sandwich Panels with Cementitious Composite Faces. Brittle Matrix Composites 8, v.8, p. 99-108, 2007.

D’ALMEIDA, A. L. F. S.; MELO FILHO, J. A.; TOLEDO FILHO, R. D. Use of curaua fibers as reinforcement in cement composites. Chemical Engineering Transactions, v. 17, n. 1, p. 1717-1722, 2009. 
D’ALMEIDA, A.; TOLEDO FILHO, R.; MELO FILHO, J. Cement composites reinforced by short curaua fibers. Revista Materia, v. 15, n. 2, p. 153-159, 2010.

DANIEL, I. M.; ABOT, J. L. Fabrication, testing and analysis of composite sandwich beams. Composites Science and Technology, v. 60, n. 12-13, p. 2455-2463, 2000.

DANIEL, I. M.; GDOUTOS, E. E. Failure modes of composite sandwich beams. Theoretical and Applied Mechanics, v. 35, n. 1-3, p. 105-118, 2008.

DAVIES, J. M. Lightweight Sandwich Construction. Oxford, John Wiley \& Sons, 2008.

DE OLIVEIRA, F. H.; HELFER, A. L.; AMICO, S. C. Mechanical behavior of unidirectional curaua fiber and glass fiber composites. In: Macromolecular Symposia. p. 83-92, 2012.

DEY, V. et al. Flexural impact response of textile-reinforced aerated concrete sandwich panels. Materials and Design, v. 86, p. 187-197, 2015.

DEY, V.; BONAKDAR, A.; MOBASHER, B. Low-velocity flexural impact response of fiberreinforced aerated concrete. Cement and Concrete Composites, v. 49, p. 100-110, 2014.

DITTENBER, D. B.; GANGARAO, H. V. S. Critical review of recent publications on use of natural composites in infrastructure. Composites Part A: Applied Science and Manufacturing, v. 43, n. 8, p. 1419-1429, 2012.

DOMINGO, E. R.; An Introduction to Autoclaved Aerated Concrete including design requirements using strength design. Manhattan, 2008. Dissertação (mestrado), Kansas State University.

DU, L.; FOLLIARD, K. J. Mechanisms of air entrainment in concrete. Cement and Concrete Research, v. 35, n. 8, p. 1463-1471, 2005.

DUFRESNE, A.; BELGACEM, M. Cellulose-reinforced composites: from micro to nanoscale. Polímeros, v. 23, n. 3, p. 277-286, 2013.

DUTKIEWICZ, J. Superelasticity and shape memory effect in copper base alloys. Acta Physica Polonica A, v. 96, p. 197-212, 1999.

EINEA, A. et al. State-of-the-Art of Precast Concrete Sandwich Panels. PCI Journal, v. 36, n. 6, p. 78-98, 1991.

ELKASHEF, M.; ABDELMOOTY, M. Investigating the use of autoclaved aerated concrete as an infill in reinforced concrete sandwich panels. Materials and Structures, v. 48, n. 7, p. 2133 2146, 2015.

FELEKOĞLU, B.; TOSUN, K.; BARADAN, B. Effects of fibre type and matrix structure on the mechanical performance of self-compacting micro-concrete composites. Cement and Concrete Research, v. 39, n. 11, p. 1023-1032, 2009.

FENGEL, D.; WEGENER, G. Wood: chemistry, ultrastructure, reactions. Berlin: Walter de Gruyter, 2011. 
FERREIRA, S. R. Influência da hornificação na aderência fibra-matriz e no comportamento mecânico de compósitos cimentícios reforçados com fibras curtas de sisal. Feira de Santana, 2012. Universidade Estadual de Feira de Santana.

FERREIRA, S. R. et al. Effect of Natural Fiber Hornification on the Fiber Matrix Interface in Cement Based Composite Systems. In: Key Engineering Materials. Trans Tech Publications, 2016.

FIDELIS, M. E. A. Desenvolvimento e caracterização mecânica de compósitos cimentícios têxteis reforçados com fibras de juta. Rio de Janeiro, 2014. Tese (doutorado), UFRJ/COPPE.

FIDELIS, M. E. A. et al. The effect of accelerated aging on the interface of jute textile reinforced concrete. Cement and Concrete Composites, v. 74, p. 7-15, 2016.

FOLIE, G. M. The behaviour and analysis of orthotropic sandwich plates. Building Science, v.6, n. 2, p. 57-67, 1971.

FRAZÃO, C. et al. Development of sandwich panels combining Sisal Fiber-Cement Composites and Fiber-Reinforced Lightweight Concrete. Cement and Concrete Composites, v. 86, p. 206-223, 2018.

FUDGE, C. A.; HACKER, J. N. UK housing and climate change: Performance evaluation using AAC. In: Autoclaved Aerated Concrete - Limbachiya and Roberts (eds). London: Taylor \& Francis Group, 2005.

GARA, F. et al. Experimental tests and numerical modelling of wall sandwich panels. Engineering Structures, v. 37, p. 193-204, 2012.

GARTNER, E. Industrially interesting approaches to "low- $\mathrm{CO}_{2}$ " cements. Cement and Concrete Research, v. 34, n. 9, p. 1489-1498, 2004.

GAWIN, D.; KOSNY, J.; WILKES, K. Thermal Conductivity of Moist Cellular Concrete Experimental and Numerical Study. American Society of Heating, Refrigerating and AirConditioning Engineers-ASHRAE, 2004.

GIBSON, L. J.; ASHBY, M. F. Cellular solids: structure and properties. MRS Bulletin, 1997.

GRAM, H. E. Durability of natural fibres in concrete. Swedish Agency for Research Cooperation with Developing Countries, 1984.

GRIES, T. et al. Textiles. State-of-the-Art Report of RILEM Technical Committee 201TRC: Textile Reinforced Concrete, p. 11-27, 2006.

HAAS, M. The future of AAC-from a material scientist's point of view. In: Autoclaved Aerated Concrete - Limbachiya and Roberts (eds). London: Taylor \& Francis Group, 2005.

HAMAD, A. J. Materials, Production, Properties and Application of Aerated Lightweight Concrete: Review. International Journal of Materials Science and Engineering, v. 2, n. 2, p. 152-157, 2014.

HÄNNINEN, T. Studies on the ultrastructure of natural fibres and its effects on the fibre 
utilization, Finland, 2011.Thesis (doctoral), Aalto University.

HAUSER, A.; EGGENBERGER, U.; MUMENTHALER, T. Fly ash from cellulose industry as secondary raw material in autoclaved aerated concrete. Cement and Concrete Research, v. 29, n. 3, p. 297-302, 1999.

HEGGER, J. et al. Mechanical behaviour of textile reinforced concrete. In: State-of-the-Art Report of RILEM Technical Committee 201-TRC: Textile Reinforced Concrete. p. 133186, 2006.

HEGGER, J.; HORSTMANN, M. Light-weight TRC sandwich building envelopes. In: Proceedings of the International Conference "Excellence in Concrete Construction through Innovation, 2008.

HEIKAL, M.; MORSY, A. S.; ABO-EL-ENEIN, S. A. Influence of hydrothermal condition on the physico-mechanical, phase composition and microstructure of autoclaved granulated slagground sand mixes using an industrial lime-rich sludge as an activator. Advances in Cement Research, v. 17, n. 4, p. 153-160, 2005.

HOFF, G. C. Porosity-strength considerations for cellular concrete. Cement and Concrete Research, v. 2, n. 1, p. 91-100, 1972.

HOLM, A. H.; KUENZEL, H. M. Practical application of an uncertainty approach for hygrothermal building simulations-drying of an AAC flat roof. Building and Environment, v. 37, n. 8-9, p. 883-889, 2002.

HOLT, E.; RAIVIO, P. Use of gasification residues in aerated autoclaved concrete. Cement and Concrete Research, v. 35, n. 4, p. 796-802, 2005.

HULL, D.; CLYNE, T. W. An introduction to composite materials. Cambridge: Cambridge University Press, 1996.

JERMAN, M. et al. Hygric, thermal and durability properties of autoclaved aerated concrete. Construction and Building Materials, v. 41, p. 352-359, 2013.

JIN, H. Q. et al. Experimental determination and fractal modeling of the effective thermal conductivity of autoclaved aerated concrete: Effects of moisture content. International Journal of Heat and Mass Transfer, v. 92, p. 589-602, 2016.

JOHN, M. J.; THOMAS, S. Biofibres and biocomposites. Carbohydrate polymers, v. 71, n. 3, p. 343-364, 2008.

JOHN, V. M. et al. Durability of slag mortar reinforced with coconut fibre. Cement and Concrete Composites. v. 27, n. 5, p. 565-574, 2005.

JOSEPH, P. V.; JOSEPH, K.; THOMAS, S. Effect of processing variables on the mechanical properties of sisal-fiber-reinforced polypropylene composites. Composites Science and Technology, v. 59, n. 11, p. 1625-1640, 1999.

KANG, S. T.; KIM, J. K. The relation between fiber orientation and tensile behavior in an ultra high performance fiber reinforced cementitious composites (UHPFRCC). Cement and 
Concrete Research, v. 41, n. 10, p. 1001-1014, 2011..

KEYVANI, A. Thermal Performance \& Fire Resistance of Autoclaved Aerated Concrete Exposed Humidity Conditions. International Journal of Research in Engineering and Technology, v. 3, n. 3, 2014.

KORONIS, G.; SILVA, A.; FONTUL, M. Green composites: A review of adequate materials for automotive applications. Composites Part B: Engineering, v. 44, n. 1, p. 120-127, 2013.

KULKARNI, A. G. et al. Mechanical properties of banana fibres (Musa sepientum). Journal of Materials Science, v. 18, n. 8, p. 2290-2296, 1983.

KUMAR, E.M; RAMAMURTHY, K. Effect of fineness and dosage of aluminium powder on the properties of moist-cured aerated concrete. Construction and Building Materials, v. 95, p. 486-496, 2015.

KUMARIA, S.; KUMAR, S.; SINGH, R. N. The first matrix cracking behavior of fiberreinforced ceramic matrix composites. Acta Materialia, v. 45, n. 12, p. 5177-5185, 1997.

KUS, H.; NYGREN, K.; NORBERG, P. In-use performance assessment of rendered autoclaved aerated concrete walls by long-term moisture monitoring. Building and Environment, v. 39, n. 6, p. 677-687, 2004.

LAGIER, F.; KURTIS, K. E. Influence of Portland cement composition on early age reactions with metakaolin. Cement and Concrete Research, v. 37, n. 10, p. 1411-1417, 2007.

LAUKAITIS, A. et al. Influence of fibrous additives on properties of aerated autoclaved concrete forming mixtures and strength characteristics of products. Construction and Building Materials, v. 23, n. 9, p. 3034-3042, 2009.

LAUKAITIS, A.; FIKS, B. Acoustical properties of aerated autoclaved concrete. Applied Acoustics, v. 67, n. 3, p. 284-296, 2006.

LAURENT, JP; GUERRE-CHALEY, C. Influence of water content and temperature on the thermal conductivity of autoclaved aerated concrete. Materials and Structures, v. 28, p. 464 $472,1995$.

LIMA, P. R. L. Análise teórica e experimental de compósitos reforçados com fibras de sisal. Rio de Janeiro, 2004. Tese (Doutorado). Universidade Federal do Rio de Janeiro.

LIU, L. et al. Development of a $\mathrm{CO}_{2}$ solidification method for recycling autoclaved lightweight concrete waste. Journal of Materials Science Letters, v. 20, n. 19, p. 1791-1794, 2001.

LOPES, F. F. M. et al. Modificação das propriedades das fibras de curauá por acetilação. Revista Brasileira de Engenharia Agrícola e Ambiental, v. 15, n. 3, 2011.

MANALO, A.; ARAVINTHAN, T.; KARUNASENA, W. Mechanical properties characterization of the skin and core of a novel composite sandwich structure. Journal of Composite Materials, v. 47, n. 14, p. 1785-1800, 2013.

MANSUR, M. A.; AZIZ, M. A. A study of jute fibre reinforced cement composites. 
International Journal of Cement Composites and Lightweight Concrete, 1982.

MARINELLI, A. L. et al. Desenvolvimento de compósitos poliméricos com fibras vegetais naturais da biodiversidade: uma contribuição para a sustentabilidade amazônica. Polímeros: Ciência e Tecnologia, v. 18, n. 2, p. 92-99, 2008.

MARSHALL, A. C. Sandwich Construction. In: Handbook of composites. Boston: Springer Science \& Business Media, 2013, p. 254-290.

MATSUSHITA, F.; SHIBATA, S.; KAMADA, T. Microstructure Of Autoclaved Aerated Concrete Subjected To Carbonation. Durability of Building Materials and Components 8: Service life and durability of materials and components, v. 1, 1999.

MATSUSHITA, F.; AONO, Y.; SHIBATA, S. Calcium silicate structure and carbonation shrinkage of a tobermorite-based material. Cement and Concrete Research, v. 34, n. 7, p. 1251-1257, 2004.

MELO FILHO, J. Durabilidade Química e Térmica e Comportamento Mecânico de Compósitos de Alto Desempenho Reforçados com Fibras de Sisal. Rio de Janeiro, 2012. Tese (doutorado). Universidade Federal do Rio de Janeiro.

MELO FILHO, J. DE A. Desenvolvimento e caracterização de laminados cimentíceos reforçados com fibras longas de sisal. Rio de Janeiro, 2005. Programa de pós-graduação de Engenharia Civil, Universidade Federal do Rio de Janeiro.

MELO FILHO, J. DE A.; SILVA, F. D. A.; TOLEDO FILHO, R. D. Degradation kinetics and aging mechanisms on sisal fiber cement composite systems. Cement and Concrete Composites, v. 40, p. 30-39, 2013.

METHACANON, P. et al. Properties and potential application of the selected natural fibers as limited life geotextiles. Carbohydrate Polymers, v. 82, n. 4, p. 1090-1096, 2010.

MITSUDA, T; SASAKI, K; ISHIDA, H. Phase evolution during autoclaving process of aerated concrete. Journal of the American Ceramic Society, v. 75, n. 7, p. 1858-1863, 1992.

MOBASHER, B. Mechanics of fiber and textile reinforced cement composites. Boca Raton: CRC Press, 2011.

MOBASHER, B.; PAHILAJANI, J.; PELED, A. Analytical simulation of tensile response of fabric reinforced cement based composites. Cement and Concrete Composites, v. 28, n. 1, p. 77-89, 2006.

MOHANTY, A. K.; MISRA, M.; HINRICHSEN, G. Biofibres, biodegradable polymers and biocomposites: An overview. Macromolecular materials and Engineering, v. 276, n. 1, p. 1$24,2000$.

MOHNEN, D. Pectin structure and biosynthesis. Current opinion in plant biology, v. 11, n. 3, p. 266-277, 2008.

MONTEIRO, S. N. et al. Natural lignocellulosic fibers as engineering materials- An overview. Metallurgical and Materials Transactions A: Physical Metallurgy and Materials Science, 
v. 42, n. 10, 2011.

MOSTAFA, N. Y. Influence of air-cooled slag on physicochemical properties of autoclaved aerated concrete. Cement and Concrete Research, v. 35, n. 7, p. 1349-1357, 2005.

MOUSA, M. A.; UDDIN, N. Experimental and analytical study of carbon fiber-reinforced polymer (FRP)/autoclaved aerated concrete (AAC) sandwich panels. Engineering Structures, v. 31, n. 10, p. 2337-2344, 2009.

MOUSA, M. A.; UDDIN, N. Debonding of composites structural insulated sandwich panels. Journal of Reinforced Plastics and Composites, v. 29, n. 22, p. 3380-3391, 2010.

MUKHERJEE, P. S.; SATYANARAYANA, K. G. Structure and properties of some vegetable fibres. II. Pineapple fibre. Journal of Materials Science, v. 21, p. 51-56, 1986.

NARAYANAN, N.; RAMAMURTHY, K. Structure and properties of aerated concrete: A review. Cement and Concrete Composites, v. 22, n. 5, p. 321-329, 2000a.

NARAYANAN, N.; RAMAMURTHY, K. Microstructural investigations on aerated concrete. Cement and Concrete Research, v. 30, n. 3, p. 457-464, $2000 \mathrm{~b}$.

NEVILLE, A. M. Properties of Concrete. 5.ed. London: Longman, 1995.

NEWMAN, J.; CHOO, B. S. Advanced Concrete Technology 3: Processes. Elsevier, 2003.

NORDSTRAND, T.; CARLSSON, L. A.; ALLEN, H. G. Transverse shear stiffness of structural core sandwich. Composite Structures, v. 27, n. 3, p. 317-329, 1994.

PACHECO-TORGAL, F.; JALALI, S. Cementitious building materials reinforced with vegetable fibres: A review. Construction and Building Materials, v. 25, n. 2, p. 575-581, 2011.

PEHLIVANLI, Z. O. et al. The effect of different fiber reinforcement on the thermal and mechanical properties of autoclaved aerated concrete. Construction and Building Materials, v. 112 , p. $325-330,2016$.

PELED, A.; BENTUR, A. Geometrical characteristics and efficiency of textile fabrics for reinforcing cement composites. Cement and Concrete Research, v. 30, n. 5, p. 781-790, 2000.

PELED, A.; MOBASHER, B. Tensile Behavior of Fabric Cement-Based Composites: Pultruded and Cast. Journal of Materials in Civil Engineering, 2007.

PEREIRA, P. H. F. et al. Vegetal fibers in polymeric composites: a review. Polímeros, v. 25, n.1, p. 9-22, 2015.

PFLUG, J. et al. Development of a sandwich material with polypropylene/natural fiber skins and paper honeycomb core. In: Proceedings of the 10th European Conference on Composites Materials, 2002.

PICANÇO, M. DE S. Compósitos cimentícios reforçados com fibras de curauá. Rio de Janeiro, 2005. Dissertação (Mestrado). Pontifícia Universidade Católica do Rio de Janeiro. 
PIETAK, A. et al. Atomic force microscopy characterization of the surface wettability of natural fibres. Applied Surface Science, v. 253, n. 7, p. 3627-3635, 2007.

PILLING, J. Strength of Sandwich Structures. Disponível em: <http://www.mse.mtu.edu/ drjohn/my4150/sandwich/sp2.html>. Acesso em: 19 mar. 2019.

POTHAN, L. A. .; THOMAS, S.; GEORGE, J. Tensile and impact properties of banana fiber/glass fiber hybrid polyester composites. In:12th International Conference on Composite Materials, Paris, France. 1999

POTHAN, L. A.; OOMMEN, Z.; THOMAS, S. Dynamic mechanical analysis of banana fiber reinforced polyester composites. Composites Science and Technology, v. 63, n. 2, p. 283-293, 2003..

PRECON INDUSTRIAL S/A. Bloco Precon - Concreto Celular Autoclavado. Disponível em: 〈https://precon.com.br/portal/wp-content/uploads/2017/09/bloco-cca.pdf >. Acesso em: 28 de Setembro. 2018.

PRIM, P.; WITTMANN, F. H. Structure and water absorption of aerated concrete. In: Autoclaved aerated concrete, moisture and properties. Amsterdam: Elsevier Scientific Publishing Company, 1983. p. 55-69.

QU, X.; ZHAO, X. Previous and present investigations on the components, microstructure and main properties of autoclaved aerated concrete - A review. Construction and Building Materials, v. 135, p. 505-516, 2017.

RATHI, S. O.; KHANDVE, P. V. AAC Block-A New Eco-friendly Material for Construction. International Journal of Advance Engineering and Research Development, v. 2, n. 4, p. 410-414, 2015.

RILEM RECOMMENDED PRACTICE. Autoclaved Aerated Concrete: Properties, Testing and Design. London, UK: E \& FN SPON, 1993.

ROUBY, D.; REYNAUD, P. Fatigue behaviour related to interface modification during load cycling in ceramic-matrix fibre composites. Composites Science and Technology, v. 48, n. 14, p. 109-118, 1993.

ROWELL, R. M.; HAN, J. S.; ROWELL, J. S. Characterization and Factors Effecting Fiber Properties. Nat. Polym. Agrofibers Composites, 2000.

SANCHEZ, E. M. S. et al. Compósito de resina de poliéster insaturado com bagaço de canade-açúcar: influência do tratamento das fibras nas propriedades. Polímeros, 2010.

SATYANARAYANA, K. G.; GUIMARÃES, J. L.; WYPYCH, F. Studies on lignocellulosic fibers of Brazil. Part I: Source, production, morphology, properties and applications. Composites Part A: Applied Science and Manufacturing, v. 38, n. 7, 2007.

SAUMAN, Z. Effect of $\mathrm{CO}_{2}$ on porous concrete. Cement and Concrete Research, v. 2, 1972.

SAVASTANO, H.; AGOPYAN, V. Transition zone studies of vegetable fibre-cement paste composites. Cement and Concrete Composites, v. 21, n. 1, p. 49-57, 1999. 
SAVASTANO, H.; WARDEN, P. G.; COUTTS, R. S. P. Brazilian waste fibres as reinforcement for cement-based composites. Cement and Concrete Composites, v. 22, n. 5, p. 379-384, 2000.

SAVASTANO, H.; WARDEN, P. G.; COUTTS, R. S. P. Mechanically pulped sisal as reinforcement in cementitious matrices. Cement and Concrete Composites, v. 25, n. 3, p. 311-319, 2003.

SAVASTANO JR, H. Materiais à base de cimento reforçado com fibra vegetal: reciclagem de resíduos para a construção de baixo custo. São Paulo, 2000. Tese (Doutorado). Universidade de São Paulo.

SCHAEDLER, T. A.; CARTER, W. B. Architected Cellular Materials. Annual Review of Materials Research, 2016.

SCHOCH, T.; KREFT, O. The influence of moisture on the thermal conductivity of AACCement, Wapno, Beton, 2011.

SEDAN, D. et al. Mechanical properties of hemp fibre reinforced cement: Influence of the fibre/matrix interaction. Journal of the European Ceramic Society, v. 28, n. 1, p. 183-192, 2008.

SHABBAR, R.; NEDWELL, P.; WU, Z. Mechanical properties of lightweight aerated concrete with different aluminium powder content. In:MATEC Web of Conferences. EDP Sciences, 2017.

SHAMS, A.; HORSTMANN, M.; HEGGER, J. Experimental investigations on textilereinforced concrete (TRC) sandwich sections. Composite Structures, v. 118, p. 643-653, 2014.

SHENHAR, Y.; FROSTIG, Y.; ALTUS, E. Stresses and failure patterns in the bending of sandwich beams with transversely flexible cores and laminated composite skins. Composite Structures, v. 35, n. 2, p. 143-152, 1996.

SILVA, F. D. A. et al. Effect of fiber shape and morphology on interfacial bond and cracking behaviors of sisal fiber cement based composites. Cement and Concrete Composites, v. 33, n. 8, p. 814-823, 2011.

SILVA, F. D. A.; MOBASHER, B.; FILHO, R. D. T. Advances in Natural Fiber Cement Composites: A Material for the Sustainable Construction Industry. 4th Colloquium on Textile Reinforced Structures (CTRS4), p. 377-388, 2009a.

SILVA, F. D A. et al. Physical and mechanical properties of durable sisal fiber-cement composites. Construction and Building Materials, v. 24, n. 5, p. 777-785, 2010.

SILVA, F. D. A.; MOBASHER, B.; FILHO, R. D. T. Cracking mechanisms in durable sisal fiber reinforced cement composites. Cement and Concrete Composites, v. 31, n. 10, p. $721-$ 730, $2009 b$.

SILVA, R. V.; AQUINO, E. M. F. Curaua fiber: A new alternative to polymeric composites. Journal of Reinforced Plastics and Composites, v. 27, n. 1, p. 103-112, 2008. 
SOLTAN, D. G. et al. Introducing a curauá fiber reinforced cement-based composite with strain-hardening behavior. Industrial Crops and Products, v. 103, p. 1-12, 2017.

SOUZA, L. O. D. Mecanismos de fissuração e autocicatrização de compósitos cimentícios reforçados com tecido de curauá. Rio de Janeiro, 2017. Dissertação (mestrado). Pontíficia Universidade Católica do Rio de Janeiro.

SOUZA, L. O.; SOUZA, L. M. S.; SILVA, F. A. Mechanics and cracking mechanisms in natural curauá textile reinforced concrete. RILEM Bookseries, 2018.

SPINACÉ, M. A. S. et al. Characterization of lignocellulosic curaua fibres. Carbohydrate Polymers, v. 77, n. 1, p. 47-53, 2009.

STUCKES, A. D.; SIMPSON, A. The effect of moisture on the thermal conductivity of aerated concrete. Building Services Engineering Research and Technology, v. 6, n. 2, p. 49-53, 1985.

SUEKI, S. et al. Pullout-Slip Response of Fabrics Embedded in a Cement Paste Matrix. Journal of Materials in Civil Engineering, v. 19, n. 9, p. 718-727, 2007.

SWIFT, D. G. Sisal - Cement Composites and their Potential for Rural Africa. In: Composite Structures . Springer, Dordrecht, p. 774-787, 1985.

TADA, S.; NAKANO, S. Microstructural approach to properties of moist cellular concrete. In: Autoclaved aerated concrete, moisture and properties. Amsterdam: Elsevier, 1983, p. 7188 .

THILL, C. et al. Composite corrugated structures for morphing wing skin applications. Smart Materials and Structures, v. 19, n. 12, p. 124009, 2010..

TIKALSKY, P. J.; POSPISIL, J.; MACDONALD, W. A method for assessment of the freezethaw resistance of preformed foam cellular concrete. Cement and Concrete Research, v. 34, n. 5, p. 889-893, 2004.

TOLEDO FILHO, R. D. et al. Durability of compression molded sisal fiber reinforced mortar laminates. Construction and Building Materials, v. 23, n. 6, p. 2409-2420, 2009.

TOLÊDO FILHO, R. D. et al. Durability of alkali-sensitive sisal and coconut fibres in cement mortar composites. Cement and Concrete Composites, v. 22, n. 2, p. 127-143, 2000.

TOMCZAK, F.; SATYANARAYANA, K. G.; SYDENSTRICKER, T. H. D. Studies on lignocellulosic fibers of Brazil: Part III - Morphology and properties of Brazilian curauá fibers. Composites Part A: Applied Science and Manufacturing, v. 38, n. 10, p. 2227-2236, 2007.

UDDIN, N. et al. Structural characterization of hybrid Fiber reinforced Polymer (FRP)Autoclave Aerated Concrete (AAC) panels. Journal of Reinforced Plastics and Composites, v. 25, n. 9, p. 981-999, 2006.

UNGKOON, Y. et al. A preliminary study of hygrothermal performance of autoclaved aerated concrete blocks under hot humid climate of Thailand. Building Scientific Research Center, 2005. 
VINSON, J. R. Sandwich Structures. Applied Mechanics Reviews, v. 54, n. 3, p. 201-214, 2001.

VINSON, J. R. . The Behavior of Sandwich Structures of Isotropic and Composite Materials. Technomic Publishing Company, 1999.

VIZZINI, A. J. Lightweight Sandwich Structures. Encyclopedia of Aerospace Engineering. 2010 .

WENNHAGE, P. Structural-acoustic optimization of sandwich panels. Stockholm, 2001. Tese (Doutorado). Institutionen för flygteknik.

WILLIAMS PORTAL, N. et al. Bending behaviour of novel Textile Reinforced Concretefoamed concrete (TRC-FC) sandwich elements. Composite Structures, v. 177, p. 104-118, 2017.

WITTMAnN, F. H. Autoclaved Aerated Concrete, Moisture and Properties. 6. ed. Amsterdam: Elsevier Scientific Publishing Company, 1983.

WONGKEO, W. et al. Compressive strength, flexural strength and thermal conductivity of autoclaved concrete block made using bottom ash as cement replacement materials. Materials and Design, v. 35, p. 434-439, 2012.

WONGKEO, W.; CHAIPANICH, A. Compressive strength, microstructure and thermal analysis of autoclaved and air cured structural lightweight concrete made with coal bottom ash and silica fume. Materials Science and Engineering A, v. 527, n. 16-17, p. 3676-3684, 2010.

XIONG, J. et al. Sandwich Structures with Prismatic and Foam Cores: A Review. Advanced Engineering Materials, p. 1-19, 2018.

YAN, L.; KASAL, B.; HUANG, L. A review of recent research on the use of cellulosic fibres, their fibre fabric reinforced cementitious, geo-polymer and polymer composites in civil engineering. Composites Part B: Engineering, v. 92, p. 94-132, 2016.

YAO, Y. et al. Tension stiffening in textile-reinforced concrete under high speed tensile loads. Cement and Concrete Composites, 2015.

ZAMAN, I.; ISMAIL, A. ; AWANG, M. K. Influence of fiber volume fraction on the tensile properties and dynamic characteristics of coconut fiber reinforced composite. Journal of Science and Technology, v. 1, n. 1, p. 55-71, 2009.

ZENKERT, D. An Introduction to Sandwich Construction. Engineering Materials Advisory Services Ltd., 1995. 


\section{Apêndice A}

\subsection{Concreto Celular Autoclavado}

As curvas a seguir demonstram o comportamento de todos os blocos de CCA avaliados nos testes de compressão axial (módulo de elasticidade) e flexão a quatro pontos (com e sem entalhe)

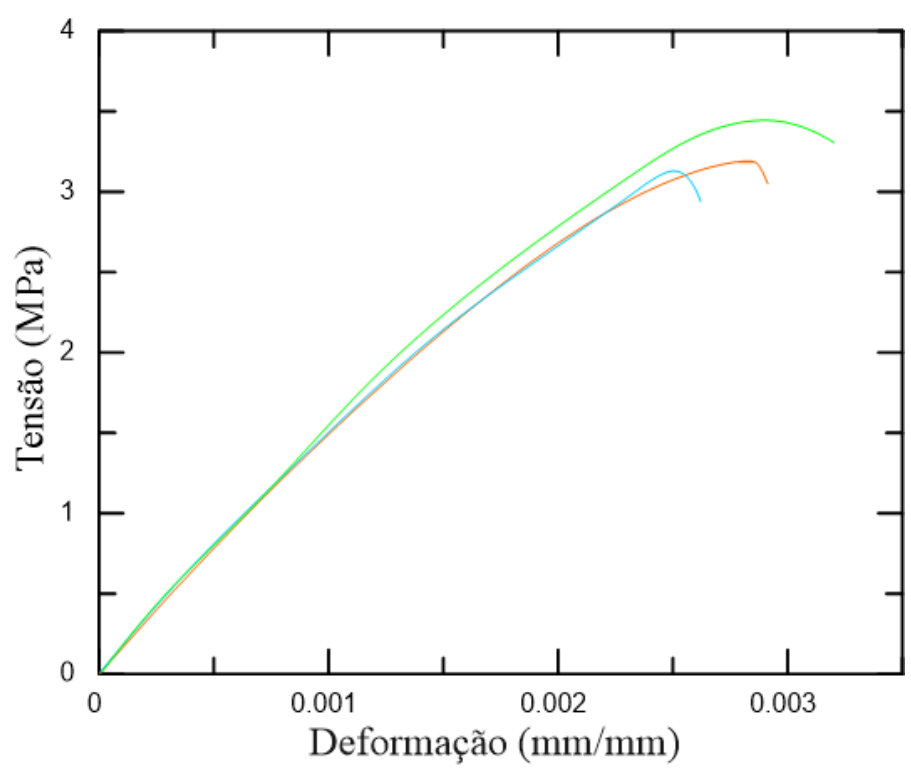

a)

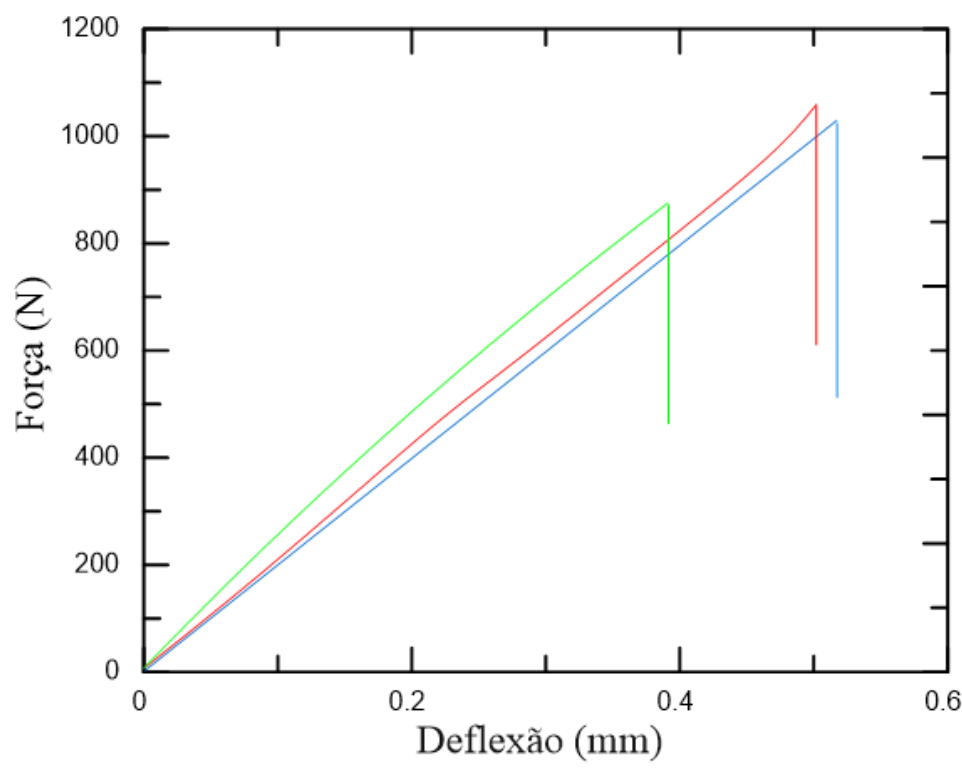

b) 


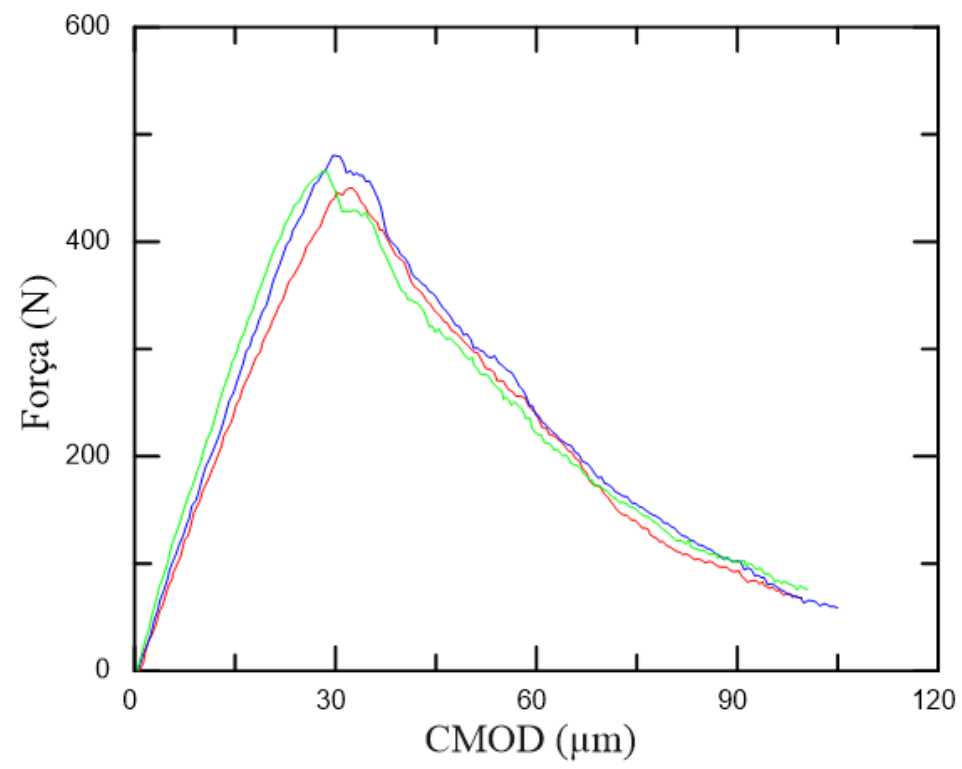

c)

Figura 8-1: Curvas apresentadas pelos blocos de CCA para os ensaios de: a) compressão axial (relação tensãodeformação); b) flexão a quatro ponto sem entalhe (relação força-deflexão); c) flexão a quatro pontos com entalhe (relação força-CMOD)

\subsection{Fibra de Curauá e Compósito Cimentício}

As curvas contidas nessa seção englobam as propriedades mecânicas da fibra de curauá e do compósito cimentício reforçado unidirecionalmente. Os ensaios de tração na fibra, tal como pull-out do tecido, tração direta e flexão a quatro pontos dos compósitos, estão expostos a seguir.

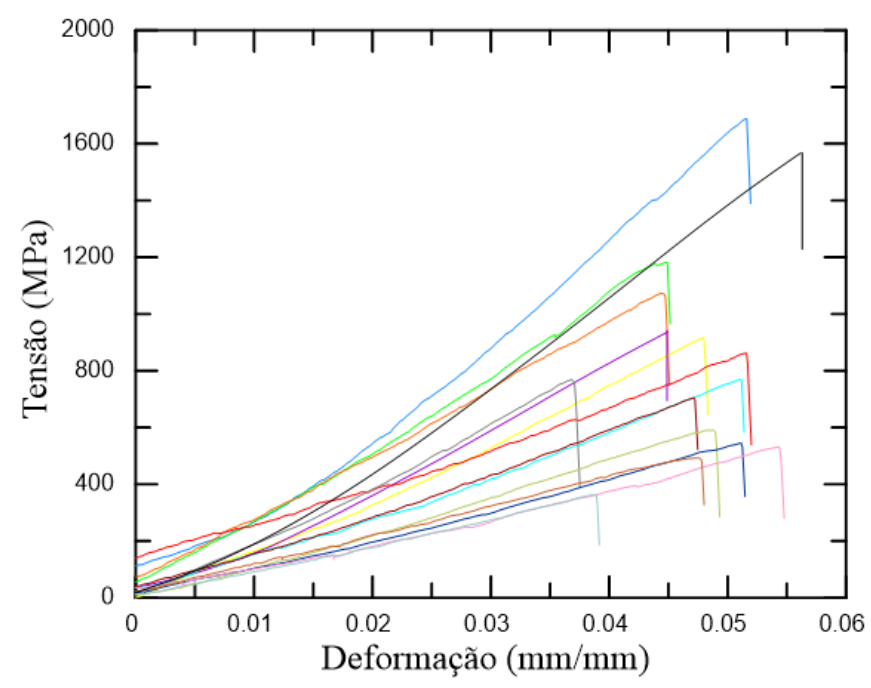

a) 


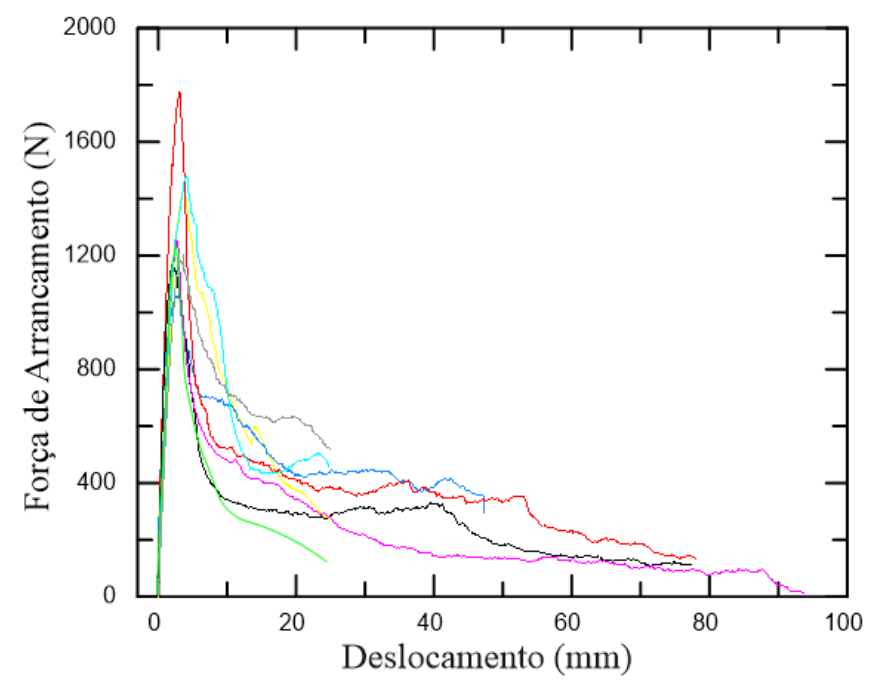

b)

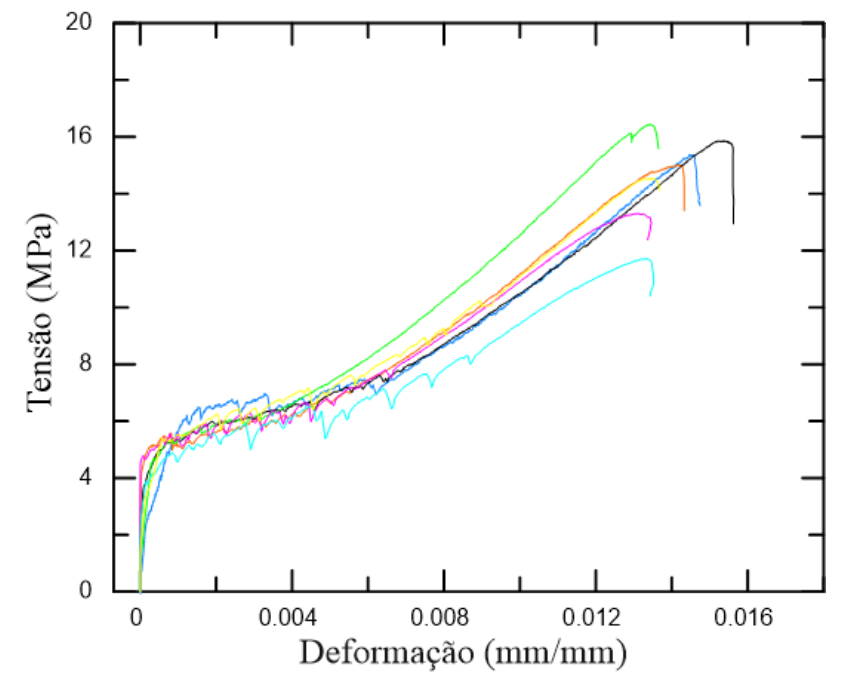

c)

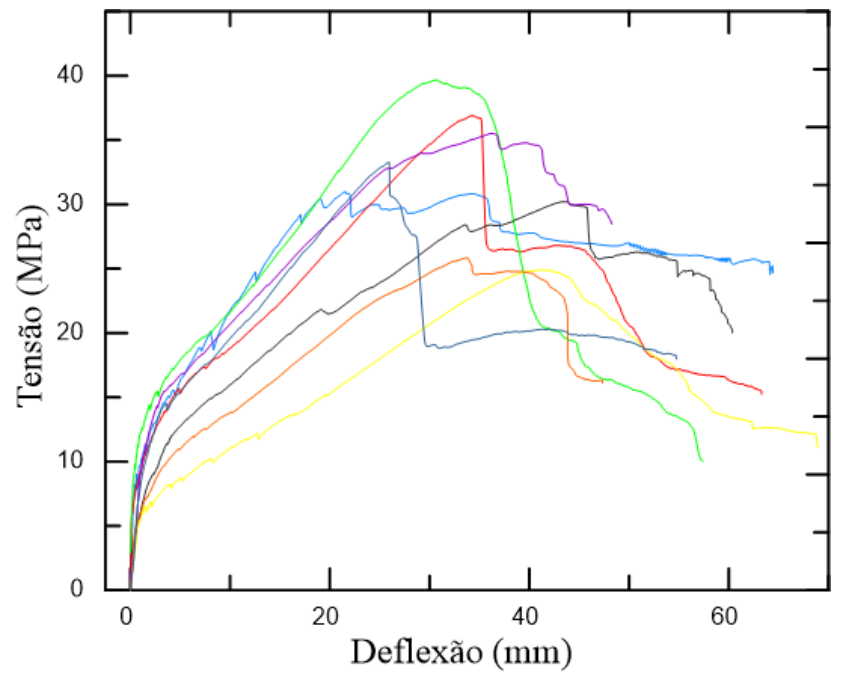

d)

Figura 8-2: Curvas obtidas para os ensaios de: a) tração direta da fibra; b) arrancamento do tecido; c) tração direta do compósito; d) flexão a quatro pontos do compósito 